IntechOpen

\title{
Public Sector \\ Crisis Management
}

Edited by Alexander Rozanov, Alexander Barannikov, Olga Belyaeva and Mikhail Smirnov
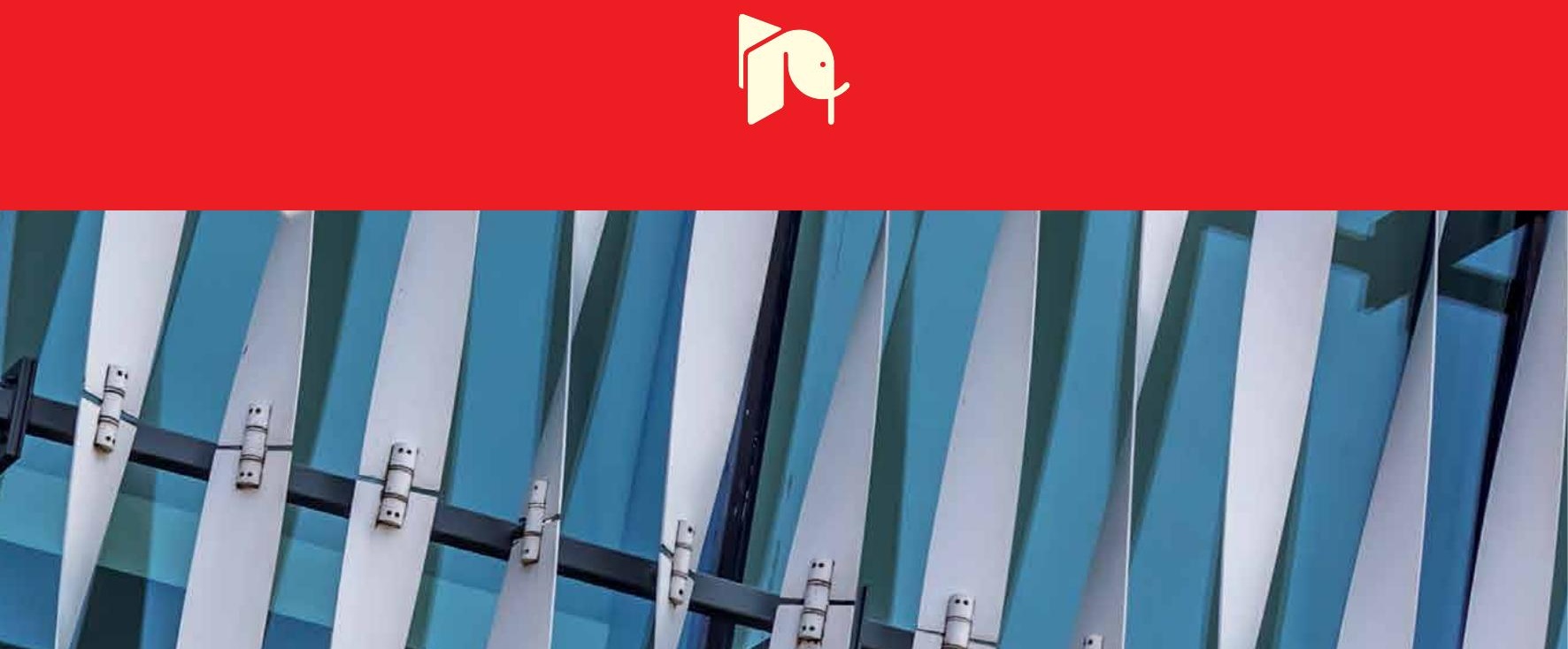



\title{
Public Sector Crisis Management
}

\author{
Edited by Alexander Rozanov, \\ Alexander Barannikov, \\ Olga Belyaeva and Mikhail Smirnov
}



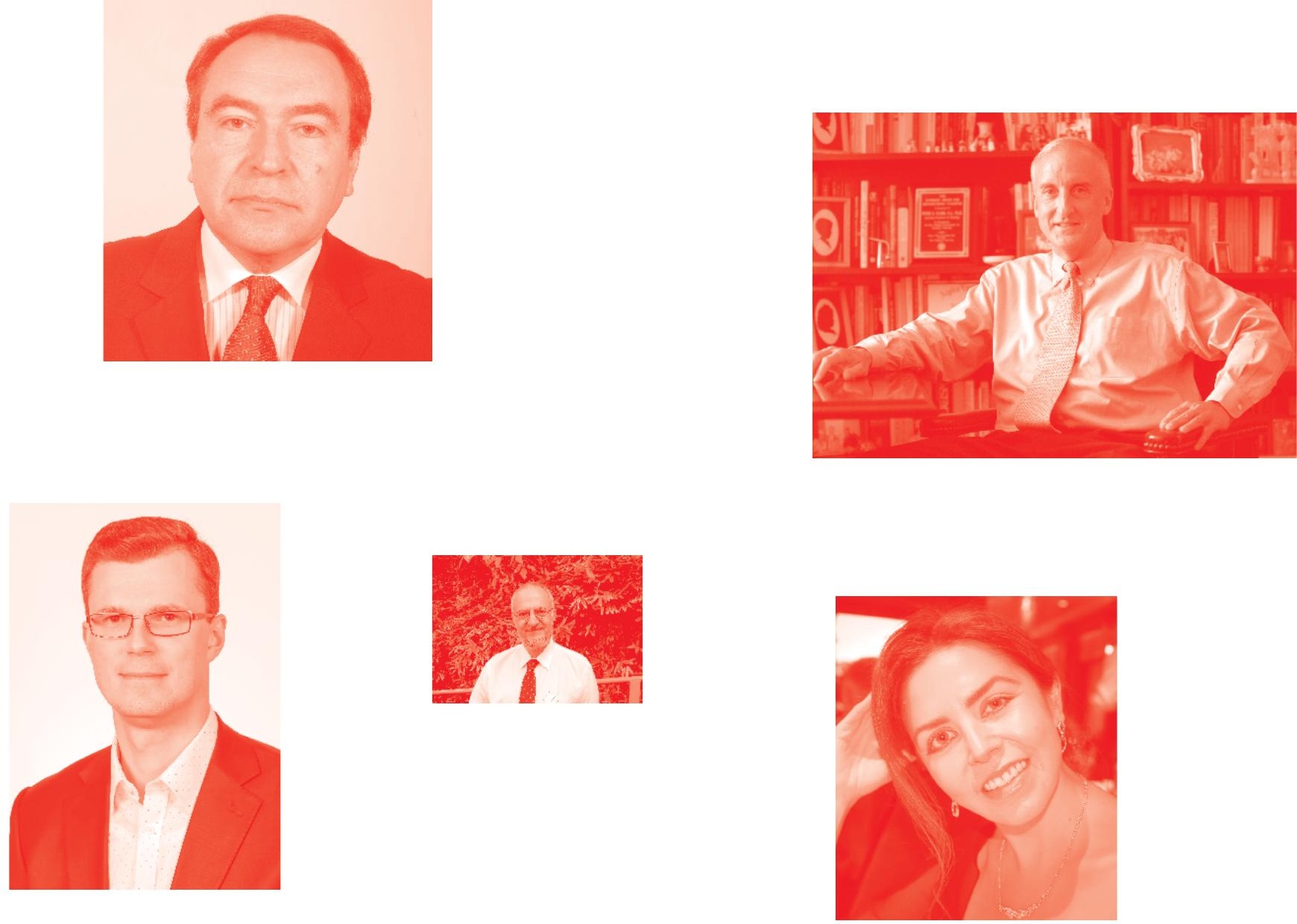

Supporting open minds since 2005
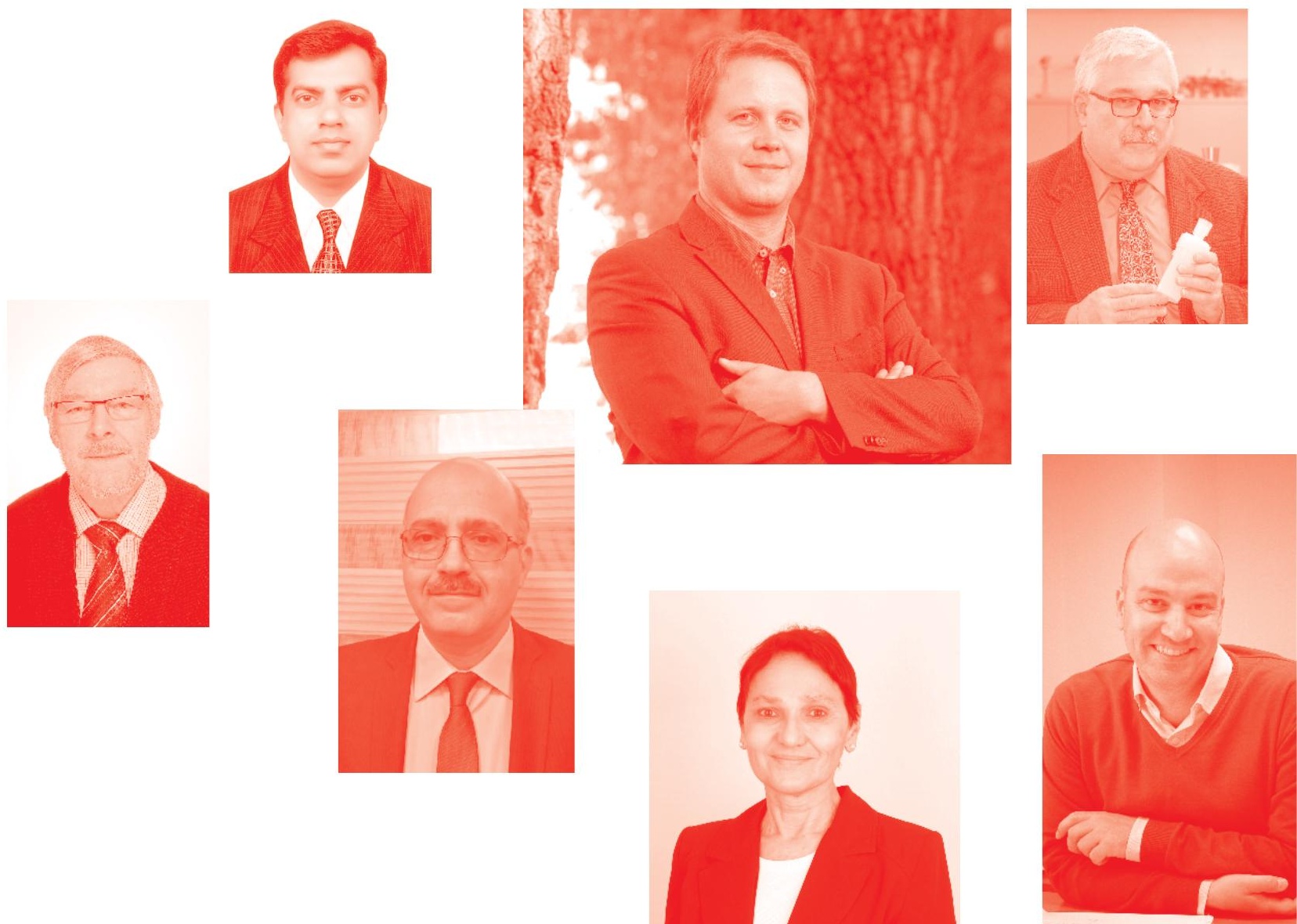
Public Sector Crisis Management

http : //dx. doi.org/10.5772/intechopen. 77623

Edited by Alexander Rozanov, Alexander Barannikov, Olga Belyaeva and Mikhail Smirnov

\section{Contributors}

Levent Yilmaz, Daniel Taye Taye Medoye, Elochukwu Nwankwo, Omar Jawabreh, Christos Lemonakis, Antonios Zairis, Alexander Rozanov, Alexander Barannikov, Olga Igorevna Belyaeva, Mikhail Smirnov, Alexandra Baranova, Natalya Ogneva, Dmitry Medvedev, Marina Danilina, Mattia Masolletti, Kwame Boateng, Svetlana Ivanova, Alla A. Nikolaeva, Zaru Dulatkyzy, Tatiana Grabovich, Vladimir Chilingaryan, Maria Krotovskaya, Biyaslan Tambiev, Maria Ivanchenko, Mohammad Ferdosi, Telisa Falianty, Arif Budimanta, Martin Hrinko, David Palička, Kiryl Rudy, Mikhail Ilichev, Ludmila Ilicheva, Leoš Hájek, Petr Kubický

๑) The Editor(s) and the Author(s) 2020

The rights of the editor(s) and the author(s) have been asserted in accordance with the Copyright, Designs and Patents Act 1988. All rights to the book as a whole are reserved by INTECHOPEN LIMITED. The book as a whole (compilation) cannot be reproduced, distributed or used for commercial or non-commercial purposes without INTECHOPEN LIMITED's written permission. Enquiries concerning the use of the book should be directed to INTECHOPEN LIMITED rights and permissions department (permissions@intechopen.com).

Violations are liable to prosecution under the governing Copyright Law .

\section{(cc) BY}

Individual chapters of this publication are distributed under the terms of the Creative Commons Attribution 3. 0 Unported License which permits commercial use, distribution and reproduction of the individual chapters, provided the original author(s) and source publication are appropriately acknowledged. If so indicated, certain images may not be included under the Creative Commons license. In such cases users will need to obtain permission from the license holder to reproduce the material. More details and guidelines concerning content reuse and adaptation can be found at http : //www . intechopen. com/copyright-policy. html.

Notice

Statements and opinions expressed in the chapters are these of the individual contributors and not necessarily those of the editors or publisher. No responsibility is accepted for the accuracy of information contained in the published chapters. The publisher assumes no responsibility for any damage or injury to persons or property arising out of the use of any materials, instructions, methods or ideas contained in the book.

First published in London, United Kingdom, 2020 by IntechOpen

IntechOpen is the global imprint of INTECHOPEN LIMITED, registered in England and Wales, registration number: 11086078 , 5 Princes Gate Court, London, SW7 2QJ, United Kingdom Printed in Croatia

British Library Cataloguing-in-Publication Data

A catalogue record for this book is available from the British Library

Additional hard and PDF copies can be obtained from orders@intechopen.com

Public Sector Crisis Management

Edited by Alexander Rozanov, Alexander Barannikov, Olga Belyaeva and Mikhail Smirnov

p. cm.

Print ISBN 978-1-83880-981-2

Online ISBN 978-1-83880-982-9

eBook (PDF) ISBN 978-1-83880-983-6 


\section{We are IntechOpen, \\ the world's leading publisher of Open Access books}

\section{Built by scientists, for scientists}

\section{$5,000+$ \\ $126,000+$ \\ International authors and editors \\ $145 \mathrm{M}+$ \\ Downloads}

Our authors are among the

151

Countries delivered to

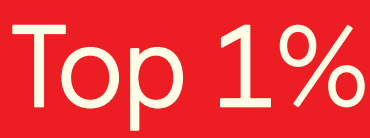

most cited scientists

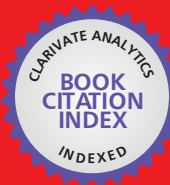

WEB OF SCIENCE ${ }^{\text {TM }}$

Selection of our books indexed in the Book Citation Index in Web of Science ${ }^{\mathrm{TM}}$ Core Collection (BKCI)

\section{Interested in publishing with us? \\ Contact book.department@intechopen.com}

Numbers displayed above are based on latest data collected.

For more information visit www.intechopen.com 



\section{Meet the editors}

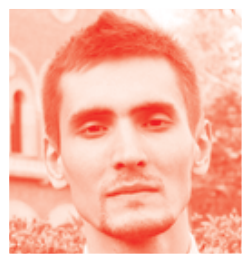

Dr. Alexander S. Rozanov is a specialist in Global Security and a graduate of Lomonosov Moscow State University (Russia). He is the author of more than 60 scientific publications. After graduating, Dr. Rozanov worked in the Russian Ministry of Foreign Affairs and the Russian Government. In 2014 he received his Ph.D. in Politics from Lomonosov Moscow State University. From 2014 to 2017, Dr. Rozanov was invited as a guest lecturer in several well-known universities - University of California, Santa Barbara (USA), Paris-Sorbonne (France), and Wroclaw University (Poland). Dr. Rozanov specializes in the analysis of global and regional conflicts, as well as the global dynamics of world development. He is a member of the European International Studies Association (Great Britain). Dr. Rozanov is an Associate Professor at the Faculty of Regional Studies and International Cooperation at the Russian Academy of National Economy and Public Administration.

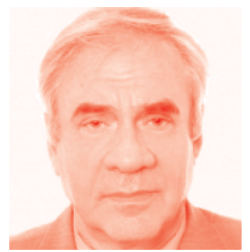

Dr. Barannikov has a $\mathrm{PhD}$ in Economics and Management. From 2012 to 2014, he was an independent expert of the Commission of the Federal Agency for the supply of weapons, military, special equipment and materiel on compliance with the requirements for official behavior of Federal civil servants of the Central Office of the Federal Agency. His list of scientific works includes more than 87 scientific works, including 39 inventions. Dr. Barannikov is a Professor at the Russian Academy of National Economy and Public Administration.

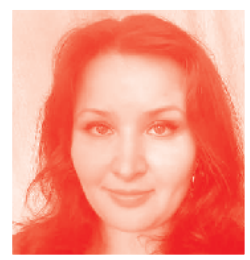

Dr. Olga Belyaeva is an Associate Professor at the Russian Academy of National Economy and Public Administration at the Department of Regional Management of the Faculty of International Regional Studies and Regional Management. She has a PhD in Regional Economy. Dr. Belyaeva has 2 specialties - a professional lawyer and an economist. Dr. Belyaeva has published more than 80 scientific publications. She has been providing lectures since 2006. From 2003 to 2006 she worked in the field of audits of small and medium-sized businesses.

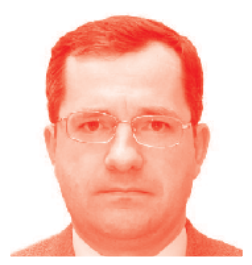

Michael Smirnov is a Professor at the Russian Academy of National Economy and Public Administration. He has a PhD in Law. For more than 15 years, Dr. Smirnov worked as a practical lawyer in international banks and consulting companies, at the same time providing lectures at Lomonosov MSU and Russian Academy of National Economy and Public Administration. He is the author of more than 60 scientific publications. Dr. Smirnov is currently the head of the Academic Program 'Legal Support of Financial Technologies'. 



\section{Contents}

Preface

Section 1

Public Sector Crisis Management: Concepts, Trends, Strategies, and Tactics

Chapter 1

Crisis Management and Communication Strategies: RUSAL's Case

by Alexander Rozanov, Maria Ivanchenko, Alexandra Baranova,

Mikhail Smirnov, Olga Belyaeva, Alexander Barannikov, Mikhail Ilichev,

Ludmila Ilicheva, Biyaslan Tambiev, Maria Krotovskaya,

Vladimir Chilingaryan, Tatiana Grabovich, Zaru Dulatkyzy, Alla Nikolaeva,

Svetlana Ivanova, Kwame Boateng, Mattia Masolletti, Marina Danilina,

Dmitry Medvedev and Natalya Ogneva

Chapter 2

The Political Economy of Crisis Recovery

by Mohammad Ferdosi

Chapter 3

Contagion, Exchange Rate, and Financial Volatility: Indonesian Case

in Global Financial Turbulence

by Telisa Falianty and Arif Budimanta

Chapter 4

State Capitalism in Belarus: Behind Economic Anemia

by Kiryl Rudy

Chapter 5

Crisis Management and the Public Sector: Key Trends and Perspectives

by Christos Lemonakis and Antonios Zairis

Section 2

Crisis Management in Practice

Chapter 6

Applying Monte Carlo Simulation in New Tech

by Levent Yilmaz 
Management of Tourism Crisis in the Middle East

by Omar Jawabreh

Chapter 8

Exploring the Three-Way Destination Safety Solution to Crisis

Management in Tourist Destinations in Rural Nigeria

by Elochukwu A. Nwankwo

Chapter 9

Crisis Management in Nigeria's Public Sector and the Impact of the Organised Labour Union: Interrogating the Nexus between Industrial Harmony and Political Stability

by Daniel Taye Medoye

\section{Section 3}

Applied Aspects of Crisis Management for National Security and Law Enforcement

Chapter 10

The Police Development and Protection of Soft Targets

by Martin Hrinko, David Palička, Leoš Hájek and Petr Kubický 


\section{Preface}

When talking about the concept of "management", we must not forget about such an important area of application as the public sector. Historically, the management staff of state-level institutions and enterprises solved the most complex and largescale tasks. That is why the existence and development of the public sector formed the basis of what is now commonly understood by the word "management". Most often, the meaning of this term is defined as management and leadership skills. Of course, the principles of management in the public sphere and commerce are different, but they have a lot in common.

The modern word "crisis" comes from the Latin crisis, meaning a crucial situation or turning point. In medicine, the term "crisis" still retains this meaning and denotes a sharp deterioration of the patient's condition, which may be followed by recovery from the disease or death.

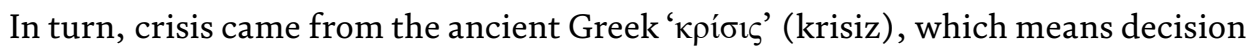
or choice and has etymological origin from the verb ' $\kappa \rho i ́ w \omega$ ' (crino) - to decide, which was used in ancient judicial practice to refer to the actions of the trial, including sentencing. Later, the noun ' $\kappa$ í⿴\zh11s' received additional meanings such as outcome (battle), dispute, contest, and even interpretation (dream), but no negative meaning was given.

The term "crisis management" first appeared in press after the military-political conflict between the Soviet Union and the United States in 1962 (the so-called "Caribbean or Cuban crisis"). The essence of the crisis was that the Soviet Union began to deploy medium-range missiles in Cuba that could threaten the security of the entire United States. In turn, the US government, in an effort to prevent this threat from being realized, established a naval blockade of Cuba and stated that all Soviet ships that are sent to Cuba will be searched, and ships with missiles will be stopped and, if necessary, sunk. In response, the Soviet Union declared that an attack on at least one Soviet ship would be the beginning of World War III. To make recommendations on how to get out of this extremely dangerous situation without compromising the national security of the United States, the President of the United States, J. Kennedy created a special group led by his brother R. Kennedy. After several days of round-the-clock discussions and consultations, the Kennedy group was able to develop proposals that were acceptable to both the United States and the USSR. The conflict was over, and the activities of the R. Kennedy group were called "crisis management".

The term "crisis management" was applied to business only after the publication of the monograph "Crisis Management: Planning for the Inevitable" by Steven Fink in 1986. Since then, this term has turned from a journalistic cliche into a scientific concept, and its concept, theory, and methodology have been further developed.

It is the turning point in the meaning of the word "crisis" that indicates the possibility of changing the situation by making decisions that contribute to changing the vector of development of events from destruction to recovery and further development. 
From the above, the general definition of the term "crisis management" follows as a process of saving the system from its destructive effects.

Our book consists of three key interrelated sections:

\section{Part I. Public Sector Crisis Management: Concepts, Trends, Strategies, and Tactics}

The crisis manager begins his work by conducting a rapid analysis of the system state, after which he develops an approach and implements measures to stabilize the situation. At this stage, all available resources (administrative, financial, and labor) are mobilized and special attention is paid to increasing the loyalty of the staff to the activities carried out. When a critical situation has been successfully stabilized, a detailed diagnosis is carried out to identify the key problems and causes of the crisis, which determines the best way to overcome the crisis situation as a whole.

The activity of the crisis manager is always temporary and stops as a result of a favorable overcoming of the crisis or vice versa-the destruction of the system. Therefore, the criterion for the success of a manager in emergency crisis management is effectiveness as an absolute measure of the presence or absence of a result—it either exists or does not exist.

\section{Part II. Crisis Management in Practice}

It is established that the sources of business crisis are often internal reasons related to the processes of growth and development of the organization as a self-organizing system. In order to classify such crises, some authors compare the development of an organization with the development of a person and distinguish the so-called life cycles of organizations. Prominent representatives of this approach are Larry Greiner and Itschak Adizes.

There is also an alternative approach that has won many supporters. Created in 1990, the American Institute for Crisis Management (ICM) proposed to divide all the causes of crises into two categories: sudden and smoldering.

Sudden crises are unexpected and abrupt disruptions to the economic activity of an enterprise caused by natural or man-made circumstances, as well as damage to the company's reputation.

Smoldering crises are usually caused by problems that have been secretly developing in the company and were not known either inside or outside the company until the moment of their manifestation, and which can lead to serious threats or losses.

\section{Part III. Applied Aspects of Crisis Management for National Security and Law Enforcement}

The purpose of anti-crisis regulation is to be a tool for modernizing society. World experience and modern management science have proved that a country can only break out of the grip of the crisis that has befallen it and move to a new stage of development if there is an innovative type of management.

We sincerely hope that this book will contribute to introducing a better crisis management system that could be useful for countries around the world. 
We want to thank IntechOpen for the opportunity to publish such a book project and the Author Service Managers Rebekah Pribetic and Dajana Pemac for their patience, constant support, and time-consuming efforts.

Alexander Rozanov, Alexander Barannikov, Olga Belyaeva and Mikhail Smirnov

Russian Academy of National Economy and Public Administration,

Russia 

Section 1

\section{Public Sector Crisis Management: Concepts, Trends, Strategies, and Tactics}





\title{
Crisis Management and Communication Strategies: RUSAL's Case
}

Alexander Rozanov, Maria Ivanchenko, Alexandra Baranova, Mikhail Smirnov, Olga Belyaeva, Alexander Barannikov, Mikhail Ilichev, Ludmila Ilicheva, Biyaslan Tambiev, Maria Krotovskaya, Vladimir Chilingaryan, Tatiana Grabovich, Zaru Dulatkyzy, Alla Nikolaeva, Svetlana Ivanova, Kwame Boateng, Mattia Masolletti, Marina Danilina, Dmitry Medvedev and Natalya Ogneva

\begin{abstract}
No company is immune to crisis situations, an affirmation which, despite its triviality, is undeniably true. However, from the early 2014, such statement may have become even more true to Russian corporations, as the annexation of the Crimean Peninsula gave start to rounds of economic sanctions that are still perpetrated today. Such measures, which were initiated in response to the Kremlin's political maneuvers, have hit a number of Russian companies, and increased the degree of uncertainty in which they have to operate, as they see economic restriction's impact not only on the business activity tangible factors-i.e., economic rewards, service, and performance-but also on intangible factors-i.e., image and reputation-as well. Crises are integral parts of all world systems, unfortunately. While they are a theoretically well-understood issue, in practice, crises are perceived as a very painful phenomenon. A crisis can be compared to riding a roller coaster. First, as we gain speed and climb up the tracks we are filled with a sense of joy and delight. These feelings are quickly replaced with anticipation, panic, and fear as the roller coaster plunges into the "abyss."
\end{abstract}

Keywords: crisis management, crisis, communication strategies, RUSAL, risk management

\section{Introduction}

Crises are integral parts of all world systems, unfortunately. While they are a theoretically well-understood issue, in practice, crises are perceived as a very painful phenomenon. A crisis can be compared to riding a roller coaster. First, as we gain speed and climb up the tracks we are filled with a sense of joy and delight. 
These feelings are quickly replaced with anticipation, panic, and fear as the roller coaster plunges into the "abyss."

Given the likeliness of finding itself in the midst of crises resulting from the geopolitical crossfire between Russia and the U.S., some guidelines in the form of a strategy are needed, and the paper will aim at providing them. It should be made clear, though, that the strategy does not seek to attain this purpose only, as it also intends to formulate a set of directives to mitigate negative repercussions for the corporate reputation within unstable geopolitical conditions. More precisely, by taking into exam the case study of RUSAL-a leader in the Russian metal and mining industry, which after being put on the U.S. Congress blacklist on the base of presumed closeness to the Russian government last April has recently obtained to have sanctions against it terminated-a communications strategy that could serve companies to ease the sanctions-lifting process will be outlined.

A crisis is something that can stimulate an almost infinite number of associations in one's mind. Due to the extremely various scope of actions that this word may include-from natural catastrophes to personal problems - it is extremely hard to find a definition which can perfectly fit any critical occurrence. As has already been established, the research will deal with crises at the international political level, e.g., geopolitical tensions between the U.S. and Russia, which have led to crises at the business level, e.g., sanctions and blacklisting of Russian companies. Even if the idea of crisis is narrowed down to these two specific contexts, it may still be hard to find a generally accepted definition, although some consistency among all the diverse descriptions might be observed. In the field of international politics, Coombs [1] affirmed that there is no commonly accepted idea of international crisis, as a crisis is usually defined by and in the terms of the involved parties. For example, Tucker and Melewar [2] described the Cuban Missile Crisis during the Cold War by mentioning some elements necessary to understand the nature of such crisis, including the perception of high threat to important values and objectives, the feeling of being caught unaware, and having short time to respond.

These elements were seen by the American decision-makers as the reasons to classify the Cuban Missile situation as crisis. Conversely, according to other scholars, an international crisis is any situation in which there is some significant change in the normal interaction patterns between nations [3].

More precisely, as explained by Young, an international crisis consists of "a set of rapidly unfolding events which raises the impact of destabilizing forces in the general system substantially above 'normal' (i.e., average) levels and increases the likelihood of violence occurring in the system" [3]. Thus, at least as far as international politics is concerned, the definition of a crisis closely depends upon the approach which is used to analyze a situation. If, on the one hand, a crisis can be defined by the definitional approach focusing on the decision-making perspective, on the other, it can be defined by the way decisions taken by nations that have an impact on the system and the ordinary flow of politics. Defining a crisis in corporate context is equally difficult. As a matter of fact, despite increasing scientific interest in the issue and the importance that crisis management functions are recognized, there is still no generally accepted terminology for organizational crises. Based on a sample of 20 in-depth interviews conducted in 2014 with senior crisis communicators about organizational crisis recovery, crises were largely defined as "events which have the potential to negatively impact organizations' operations" [1]. Well before, O’Rourke [2] had claimed that although such bad events may be all unique, they do share some common characteristics. These characteristics include an element of surprise, which can make crisis management even more difficult, insufficient information, which makes it hard for a company to explain all the questions it is usually asked right away. In addition, the quick pace of events and the fact that the 
situation can go south very rapidly are reflected by the intense scrutiny and media attention to which the whole matter is normally accompanied with.

Similar to O'Rourke's view is the one of Coombs [1] for which a crisis is a threat that can potentially damage an organization and its stakeholders in three regardspublic safety, financial loss, and reputation loss. In particular, a crisis represents a threat to corporate reputation because it gives people reasons to think badly of the organization. Alongside many of the accusations raised by OFAC against Russia were not proved to be true and the motives behind sanctions also came into question, a crisis here could trace the idea of scandal which, according to Davis [2], derives from extensively publicized allegations that damage or attempt to damage the reputation of another party. A scandal can lead to stakeholders having more distrust for the party involved, which is likely to come out of the situation with a damaged reputation. Many other definitions and synonyms for the term "crisis" exist. However, it is the idea conceptualized by Coombs [1], the one that will be referred to in the course of the paper. Such choice was dictated both by the fact that further theories of his will be cited later on in the work, and also by the fact that in his definitions he stressed the potential impact of crises on corporate reputation.

As previously mentioned, crises can affect a company's tangible and intangible assets. Therefore, it is logical that crisis management is among the most important management functions. In fact, due to the inevitability of a crisis developing, crisis preparation may be a critical determinant of survival for any organization. Thus, strategic crisis preparation is becoming increasingly important as companies try to cope effectively with potential crises [1]. Once again, as for the concepts of corporate reputation and crisis, there are many definitions to crisis management. The first ground of debate comes with the differentiation between crisis management and risk management, which both deal with threats that impact the well running of the organization's systems and the well-being of its individuals [3]. Despite often being mistakenly thought to be the same, crisis management and risk management are two distinguished parts of the general domain of organizational management. Crisis management deals with critical situations mostly from a reactive perspective-e.g., it tries to limit the negative effects of an event by putting certain actions in place.

Risk management approaches threats proactively as it is concerned with identifying and correctly assessing a possible threat. Also, while risk management is treating risks individually, crisis management tries to identify the possible connections between different individual threats. Risk management consists of three different actions: the identification of risks, the evaluation of risks, and mitigation. Given the proactivity that characterizes it and the fact that it assesses threats before they actually materialize, risk management can also be referred to as crisis prevention, as it aims to create a reference framework that will allow companies to handle risk and uncertainty [2]. If implemented within a company as a continuous process, crisis prevention or risk management will considerably diminish the probability for the organization to face a crisis. The three actions of crisis prevention are just components to the larger crisis management process, which deals with crises before, during, and after they have occurred. Therefore, the concepts of risk management and crisis management do not overlap, rather, they are two different organizational practices that aim at increasing the capacity of a company to cope in the most efficient way with any crisis that arises, which might put in danger its functionality or even existence. Having clarified this point, some definitions of crisis management will be discussed further. Coombs [1] intended crisis management as a process designed to prevent or lessen the damage that a crisis can inflict on an organization and its stakeholders. As hinted earlier, such process can be divided into precrisis, crisis response, and postcrisis phases. In order to be effective, crisis management 
needs to handle the threats in a sequential way. Some additional criteria to assess the effectiveness of such process were suggested by Pearson and Clair [2].

Essentially, given the variety of negative effects crises are usually accompanied by, to judge as effective all the efforts of a company aimed at pulling it out of a crisis would be inappropriate; likewise, the simple survival of the company may not be enough of an indicator of the effectiveness rather ineffectiveness of such efforts and of the crisis management process in general. However, it is possible to define crisis management as effective when operations are sustained or resumed, and internal and external stakeholders' losses are minimized, and learning occurs so that lessons are transferred to future incidents [4]. More precisely, crisis management was viewed by Pearson and Clair as a "systematic attempt by organizational members with external stakeholders to avert crises or to effectively manage those that do occur" [3], whose effectiveness is evidenced when "potential crises are averted or when key stakeholders believe that the success outcomes of short and long-range impacts of crises outweigh the failure outcomes" [1]. Apart from the issues that arise when considering the definition, the complexity of the concept is also reflected by the number of crisis management models in the existing literature. Given the fact that the quantity of information in the volumes on crisis management can be overwhelming, only the three crisis management models that have been indicated by Coombs [1] to be the most influential — the three-stage model, Fink's four-stage model [2], and Mitroff's five-stage model [5] — will be overviewed. Among the first crisis management models is the three-stage one, which is attributed to no particular scholar. Such model is characterized by three stages-precrisis, crisis, and postcrisis. The precrisis stage deals with all the proactive aspects of crisis prevention; the crisis stage refers to the measures taken in response to the occurrence of the crisis event; and the postcrisis mostly about ensuring that the crisis is over, and learning from the event. Similar to the three-stage model is the model proposed by Fink [2]. Essentially, S. Fink compared the crisis to a life cycle, which can be divided into four different stages: the prodromal stage, the acute stage, the chronic stage, and the resolution stage.

The prodromal stage- the denomination comes from the Greek term "prodrome" which means "running before"-can be traced back to the three-stage model precrisis stage, during which the professionals need to adopt a proactive approach in order to detect the signals of an impending crisis. Then, following a trigger event, the acute stage initiates and the actual crisis begins. This stage is characterized by the crisis event and the resulting damage. The severity and damage can depend upon the prevention activities carried out during the prodromal stage. The third phase is labeled as chronic stage, as here the main crisis occurrence might have been managed. However, the lasting effects of the incident might extend the duration of the life cycle and make the shift toward the resolution stage-which is identified with the clear end to the crisis-more difficult. Some of the elements firstly introduced by the three-stage model and then readapted by Fink have also been shared by Mitroff's [5] five-stage crisis management model, which includes signal detection, probing and prevention, damage containment, recovery, and learning. The first two stages include all the proactive steps that an organization can take prior to a crisis event. As signal detection consists of identifying the signs of possible crises, it is much like Fink's prodromal stage; probing and prevention, instead, constitute a new phase in which known crises are observed and researched in order to determine ways to prevent them from happening. The last three phases of Mitroff's model vary just in a minor extent from Fink's acute, chronic, and resolution stages. As a matter of fact, they are all devoted to the containment of the crisis and to the operations that should be undertaken to facilitate the return to the precrisis status quo. The slight differences between the two 
authors arise from the way in which they have structured their models. As it was mentioned before, Mitroff's model [5] is cyclical, unlikely from Fink's. Thus, the learning stage allows an organization to integrate what it has learned from the crisis into its organizational philosophy, and to further apply it in the future. The model by Fink simply states that resolution occurs when the crisis is no longer a concern and does not bring any mention for what concerns future applications. Although disregarded by Fink, the idea that organizations can and should learn from crisis-because otherwise they would be susceptible to similar critical events-was acknowledged by the three-stage model as well. As the idea that companies should consider crises and other activities from the past will return in a number of passages later in the composition, which happens to be divided into three parts itself, the paper could also be referred to as a three-stage crisis management model. Further clarifications will be made throughout the paper.

\section{RUSAL's case}

As RUSAL obtained to be delisted from the U.S. Treasury OFAC sanctions list on January 27, 2019 [6], after being put under economic restrictions less than 1 year before, on April 6, 2018 [7], it was thought that Deripaska's former company might have had some strategy, or at the least some guidelines to resort to in case of sanctions imposition. Subsequently, a more in-depth analysis of the whole sanctions on RUSAL affair was carried out by the process of deductive reasoning. Deductive reasoning-as opposed to inductive reasoning_can be defined as the process for which the truth of the input propositions-or premises-logically guarantees the truth of the output proposition-or conclusion [6]. Such premises may be propositions that the reasoner believes, or assumptions that the reasoner is simply exploring. An example of deductive reasoning is displayed in the following: premise 1: every football player must wear a helmet while playing in a football game; premise 2: Joseph is a football player; conclusion: as Joseph is a football player, then he must be wearing a football helmet while playing in a football game. Before applying deductive reasoning to the RUSAL case, it should be reminded that a strategy is a method or a plan intended to bring about a desired future, such as the achievement of a goal, or solution to a problem [7]. In case of RUSAL, the possible solution could be connected with the plan to ease the sanctions-lifting process, given the fact that the company was freed from U.S. economic restrictions within a rather short period of time $[8,9]$.

Here, deductive reasoning might be applied as follows:

- premise 1: RUSAL had sanctions against it lifted in a short period of time;

- premise 2: a strategy serves to solve a problem, and sanctions are such; and

- conclusion: therefore, RUSAL must have resorted to a strategy.

To ascertain whether a strategy was actually used, a content analysis of press releases and media articles coming from the involved parties and a number of diverse media sources and newswire agencies was conducted. Another aim of the analysis was to seek to identify the strategical measures that RUSAL had employed, so that they could be implemented in the overall aim of the research-to provide a global communications strategy for companies operating under economic sanctions, or in the context of adverse geopolitical situation at the state level. In terms of time, contents taken into account span from sanctions imposition-April 6, 
2018 - to sanctions lifting-January 27, 2019-except for a few pieces of news dating back to March 2019. In terms of sources, when it comes to the involved parties, En+ Group, RUSAL, and the U.S. Treasury press releases were mainly considered; when it comes to the media, instead, news from a number of different countriese.g., France, the United Kingdom, Ireland, Italy, and the United States-and different news organizations-e.g., Bloomberg, CNN, Financial Times, NY Times, Reuters, Wall Street Journal, and others-were considered and will be mentioned along the composition in order to get a perspective on the matter as global as possible. The content analysis first proceeded with the pieces of news from the media, not just because it was easier to retrieve them, but also because they could give a broader first glimpse of the situation and the communications practices possibly used; after, given the vagueness characterizing some articles and the fact that their veracity could not anyhow be verified, the statements from the more "official" sources-what was labeled above as "involved parties"-were taken into account. If, on the one hand, the first two sections were selected and made part of the dissertation right on the basis of the content analysis of such materials, on the other hand, the third and last section on CSR was included not following the examination of the case of RUSAL.

Even though as proved by press releases on the company [6] and Deripaska's official websites that RUSAL itself has been engaged in CSR initiatives, the inclusion of such section came more in light of the consideration of the Global Transparency Initiative (GTI) [2] campaign launched by Kaspersky Lab after the alleged accusations of working for Russian intelligence services in 2017. As a matter of fact, despite not having been put under economic restrictions, Kaspersky-in a similar way to RUSAL - suffered due to geopolitical contrasts between Russia and the U.S, as it was imposed a ban and saw operations within foreign markets compromised because of the damage to its reputation. The abovementioned GTI represents a recent case of CSR campaigning designed specifically in reaction to a crisis, something which RUSAL has not done so far, but that needs nonetheless to be considered, as it can have a vital role in restoring a company's damaged reputation [10]. Therefore, it is more accurate to say that the overall strategy takes two communication practices from the analysis of the experience of RUSAL, and integrates it with one taken from the case of Kaspersky, which responded to a crisis triggered by geopolitical motives with a CSR maneuver designed exactly for that. However, regardless of the type of crisis and how similar they might be, it should be reminded that a specific critical occurrence may pose its own specific communicational demands, and this, together with the company's resources - that may in turn be different from the ones of company of the size of RUSAL_might make it more convenient to prioritize a certain measure over another, or to use measures that are not discussed in the composition. Hence, the paper does not intend and will not be the ultimate strategical framework for companies suffering due to on-state level geopolitical clashes, but it will shed light on how to react to a type of crisis that might be experienced by other corporate players in the future, and on the communication practices that were used in that regard in the recent case of RUSAL and Kaspersky, too.

It was previously said that RUSAL represents one of the biggest companies in the metal and mining industry globally. As a matter of fact, the company, which was founded back in 2000 following a merger with SUAL (the Siberian-Urals Aluminum Company) and Glencore (a multinational commodity trading and mining company headquartered in Switzerland), became the aluminum industry leader in 2007. Although the throne of leader in terms of aluminum production was seized by the Chinese Hongqiao Group in 2015, RUSAL remains a vital player, as it has more than 62,000 employees globally and a number of facilities across 5 continents and 19 countries [2]. The man behind the consolidation of RUSAL's position in the 
global aluminum industry is the well-known Russian businessman and tycoon Oleg Deripaska, whose first moves in entrepreneurship were in the metal market. Following his involvement in the metal market, Deripaska then decided to expand his activities and founded En+ Group in 2006. En+ Group includes a number of companies from different industrial spheres, such as the energy and machinery ones. Consequently, Deripaska's predominance in both the organizational structure and the shares of these companies is obvious, as he holds approximately 70\% [7] of the shares of En+ Group of which he is founder and president. Alongside this, he has a controlling stake in RUSAL. However, some consider Deripaska to be a controversial figure: if, on the one hand, he is known for his business activities and philanthropy initiatives-e.g., Volnoye Delo, which is Russia's largest charity foundation, founded in 1998 [7] — on the other hand, he is known for having always been in close contact with some of the most important officials of the Kremline.g., Vladimir Putin, or Polina Yumasheva, the ex-wife and step-granddaughter of former Russian President Boris Yeltsin, and daughter of Valentin Yumashev, one of Yeltsin's close advisors.

Although the extent of the effective closeness of Deripaska to the Kremlin as well as the real influence of the Russian government inner circles on his actions cannot be determined, Deripaska and a number of other Russian oligarchs were accused of behaving on behalf of their government by OFAC. More precisely, Treasury Secretary Steven T. Mnuchin accused the Russian government for operating in favor of oligarchs and political elites, as well as for being engaged in "a range of malign activity around the globe, including continuing to occupy Crimea and instigate violence in eastern Ukraine, supplying the Assad regime with material and weaponry as they bomb their own civilians, attempting to subvert Western democracies, and malicious cyber activities" [7].

Thus, as oligarchs have always been profiting from such corrupt system, on April 6,2018 , economic restrictions against them were imposed. In this regard, Deripaska was designated "for having acted or purported to act for or on behalf of, directly or indirectly, a senior official of the Government of the Russian Federation, as well as pursuant to E.O. 13662 for operating in the energy 1 sector of the Russian Federation economy. Deripaska has said that he does not separate himself from the Russian state. He has also acknowledged possessing a Russian diplomatic passport, and claimed to have represented the Russian government in other countries. Deripaska has been investigated for money laundering and has been accused of threatening the lives of business rivals, illegally wiretapping a government official, and taking part in extortion and racketeering. There are also allegations that Deripaska bribed a government official, ordered the murder of a businessman, and had links to a Russian organized crime group" [6].

At that time, Deripaska owned a controlling share of En+ Group which, in turn, was controlling RUSAL, and this was enough of a motivation for the U.S. Treasury to put economic penalties on Deripaska's companies. While there was no comment from RUSAL, the En+ Group announced changes in the structure of the organization following designation on April 9, 2018, and that the company intended "to continue to fulfill its existing commitments whilst seeking solutions (which may involve adjustments to its existing agreements and arrangements in accordance with legal and regulatory requirements) to address the impact of the OFAC Sanctions" [6], although sanctions were expected to be "materially adverse to the business and prospects of the Group" [2]. Immediately after the Treasury's decision in April, the price of aluminum soared above $\$ 2500$ a ton [7]. In order to prevent the situation from further worsening, OFAC opted for watering down sanctions on En+ and RUSAL. Also, Mnuchin declared that RUSAL "felt the impact of U.S. sanctions because of its entanglement with Oleg Deripaska" [7] and that the Department 
of the Treasury did not mean to target the "hardworking people who depend on RUSAL and its subsidiaries" [2].

Moreover, Mnuchin added that RUSAL had immediately approached the U.S. treasury with a petition for delisting, and that given the collateral damage on U.S. partners and allies due to these sanctions, the issue of General Licenses extending the maintenance of the wind-down period would be considered. To sum up, it is clear that RUSAL was being penalized due to its connection with En+ Group. As highlighted by Mnuchin himself, the measures taken by the Treasury were not only affecting Deripaska's companies, but a number of U.S. political and commercial allies as well. When presenting RUSAL, it was mentioned that because of its size and number of production facilities around the world its importance could not be confined to the Russian Federation. In fact, the importance of RUSAL increases even more when talking about aluminum output, as the company alone prior sanctions was covering about $20 \%$ of the aluminum demand in Europe, and was "responsible for $7 \%$ of global aluminum production" [6]. Hence, as reported by Reuters, it is logical that the situation put into alarm a number of European countries from the very beginning, as economic restrictions led to the previously mentioned shock in the price of aluminum, which in turn resulted from the fact that RUSAL, after being imposed to sanctions, could not produce aluminum at its full capacity; this would lead to severe repercussions for the global aluminum supply-chain and, consequently, to all the European manufactory industries whose production relies upon RUSAL. Therefore, the U.S. treasury directive from April 23 to diminish the gravity of sanctions on RUSAL was dictated-or at least influenced-by the interest that many countries had in minimizing any disruption in material supplies, and in avoiding any repercussion on their aluminum-liaised industries.

Officials from countries such as France, Germany, Ireland, and Italy-countries in which are RUSAL facilities, or interest in its aluminum provision-were among the first calling for a mitigation of the restrictions. Even some competitors of RUSAL, such as the Anglo-Australian multinational corporation Rio Tinto, advocated for a change in the initial measures, as "a squeeze on the largest producer of aluminum outside China would hit businesses around the world, disrupting production of myriad goods from car and planes to cans and foil, and putting jobs at risk" [10]. So, having understood the gravity of the situation, OFAC issued the so-called General License 14, which "authorizes U.S. persons to engage in specified transactions related to winding-down or maintaining business with United Company RUSAL PLC (RUSAL) and its subsidiaries until October 23, 2018 OFAC will not impose secondary sanctions on non-U.S. persons for engaging in the same activity involving RUSAL or its subsidiaries that General License 14 authorizes U.S. persons to engage in" [2].

In fact, measures similar to General License 14-General License 12 and General License 13 - to minimize disruption to U.S. persons, partners, and allies had been already disposed from the beginning. However, as they proved to be not enough, the General License 14 was also issued. On 27 April 2018, En+ Group had announced that the day before they had submitted a formal request to OFAC to postpone the deadline of both General Licenses 12 and 13 from the initial set date (May 7, 2018), adding that "without an extension of the authorization period for General License No. 13, the ability of the Company to maintain its GDR listing on the London Stock Exchange will be materially impacted." What is more important here, though, is that En+ made it known that following negotiations, Oleg Deripaska agreed in principle to reduce his shareholding in the Company to below 50\%. Moreover, he agreed to later resign from the Board and "consent to the appointment of certain new Directors such that the Board will comprise a majority of new independent directors." 
On May 2, En+ informed its publics that OFAC announced on May 1 an extension of the authorization period under a new General License 13, which would last until June 6, 2018. If the issue of General License 14 was mainly to be attributed to the pressure exerted on the U.S. Treasury by a number of interested parties, whose normal business activity was being threatened by sanctions on En + and RUSAL, the extension of General License 13, instead, resulted from the efforts of En+ under the so-called "Barker Plan," which Lord Gregory Barker of Battle-the current executive chairman of the company-started precisely on April 27, as he convinced Deripaska give up the $70 \%$ of $\mathrm{En}+$ he then possessed. In a statement from June 6, 2018, by the French and the Jamaican governments to the U.S. FARA Unit in support of the "Barker Plan," it was stated that by that time Lord Barker and En + had already implemented the first two steps of the plan-to reduce Deripaska's ownership stake in En+ below $70 \%$ and to remove him from the Boards of both En+ and RUSAL.

The last component to replace Deripaska's allies on the Boards by independent directors was the only one remaining. In this regard, on June 27, En + announced the resignation of several members of the Board of Directors of the company. These changes were all made within the framework of the "Barker Plan." Moreover, it was stated that the new members of the Board (being selected to ensure the efficient functioning of the corporate governance structure) would be replaced after lifting the sanctions, as previously established with OFAC [10]. As the last step of the "Barker Plan" was completed, OFAC announced on September 21 that En + and RUSAL approached the U.S. "about substantial corporate governance changes that could potentially result in significant changes in control," and that to review the situation all the previous wind-down licenses would be extended until November 12. Following this, a number of further extensions of the General Licenses expiration dates were declared.

Finally, on December 19, 2018, the U.S. Department of the Treasury sent a notification to the Congress about its intention to terminate sanctions imposed on En + and RUSAL within 30 days, as it was determined that "the significant restructuring and corporate governance changes will enable them to meet the criteria for delisting." On December 26, RUSAL announced the resignation of Matthias Warnig, the company's Chairman of the Board of Directors. As expressed by Warnig's words, with the planned delisting of the company from OFAC sanctions blacklist, his resignation was the natural last step to start a new strategic development for RUSAL. At this point, the last obstacle to sanctions removal was raised by the Democratic Party.

As a matter of fact, after OFAC notified the U.S. Congress about its intent to terminate sanctions against Deripaska-linked companies, Democrats submitted a bill to the U.S. Senate to repeal such measure as they viewed it as another directive pro-Russian/pro-oligarch from the Trump administration [11]. In spite of the fact that they were joined by eleven Republicans, Democrats fell short in the vote, as only 57 senators voted in favor of prolonging sanctions enforcement, and at least 60 votes were required to approve the bill. At last, on January 27, 2019, the official delisting of En+ and RUSAL from the OFAC sanctions list was declared. As stated the next day by En+, the removal from the OFAC list was reached upon the completion of the "Barker Plan," together with some other conditions such as auditing, reporting, and certifications by both En+ and RUSAL to OFAC, in order to prove further compliance with the delisting norms. In this regard, Lord Barker of Battle added that "the strong support for this plan from both the European Union and the British government, and a coalition of nations from Sweden to Jamaica, further underpins the broad based international support for the actions of the U.S. Administration to lift sanctions. With two thirds of the Board now are controlled by independent 
directors and nearly two thirds of the company shares now are controlled by minority shareholders \& independent U.S. Trustees, there has been a fundamental shift in both governance and ownership." The ad personam restrictions on Oleg Deripaska-whose direct interest in En+ was brought below 44.95\%—are instead continued in force at present day-April 23, 2019. On March 15, 2019, the Russian oligarch filed a lawsuit in the district court of Washington D.C. against the U.S. Treasury and Secretary Steven T. Mnuchin, as sanctions left him "totally isolated" and excluded from both the American and Russian financial systems.

It was established that the term "crisis" refers to a number of different events and occurrences. A common factor of most crises is their potential to disrupt an organization's operations, while also posing both a financial and reputational threat. In this chapter, it was decided to put emphasis on the reputational component, as reputational damage can be viewed as the factor capable of bringing together crises of diverse nature. As highlighted by Coombs [1], during any crisis an organization's reputation suffers and the normal level of reputation that it enjoys among stakeholders goes down. On top of this, a call for action on part of the managers of the company is needed. In crisis contexts, one of the most important functions is crisis communication, a branch of strategic communication which deals with the use of words and actions to manage information and meaning during crisis process in order to prevent and limit the damage that can be caused [12]. Given that every crisis arises due to individual circumstance, no crisis is the same. Therefore, a communication strategy which can answer communication demands presented by diverse and specific crisis situations would represent the ideal solution. However, precisely because of the multitude of facets a crisis can present and the great number of variables that - as the En+/RUSAL case showed — might be needed to be taken into consideration, the use of terms such as "best-practice" will be avoided. Having clarified this, one of the best routes that companies under crisis circumstances can pursue is provided by the evidence-based situational crisis communication theory (SCCT), developed by Coombs in 2007 , which suggests that crisis managers should mould strategic crisis responses on the basis of the particular threat posed by the particular crisis [1]. The relevance that the Coombs model enjoys in the field of crisis communication derives precisely from its ductility and wide applicability, which is also why it was ultimately decided to use it as main component for the first building block of the communications strategy discussed in the paper. The main idea of SCCT is that a crisis, regardless of its gravity-and no matter how well it is handled-is a negative event nonetheless. During critical occurrences, the stakeholders of the company try to make sense of the situation, and they do so through the so-called attribution theory. This theory claims that people tend to search for the causes of the events, especially when those are as negative and potentially harmful as crises [3]. Essentially, the people of the organization will experience certain emotions in reaction to the event, and such emotions, together with the attributions of responsibility, are to be the determiners and the "prescribers" for managers about how to handle information and respond to the crisis. In other words, if the crisis is the result of some situational factors-factors whose control goes beyond the responsibility of the organization - then the emotions of the interested publics are likely to be not as negative as the ones of the stakeholders of a company that is deemed to be the main responsible for the outburst of the crisis. Thus, while in the first case-as the organization is not considered responsible-stakeholders' emotions will be relatively ok, in the second case, stakeholders will be likely to be angry and this will cause further reputational damage to the company. SCCT suggests that by understanding the situation and the probable reactions from the publics, crisis managers can determine which crisis communication strategies will maximize reputational protection. Therefore, first of all, crisis managers need to assess the level of the reputational 
threat that the crisis presents. To do so, three factors need to be taken into account: initial crisis responsibility, crisis history, and prior relational reputation.

Initial crisis responsibility traces back to what has been told in the previous passage-i.e., the assumption that stakeholders try to understand the degree of involvement that the organization has in the outbreak of a crisis, and to what extent stakeholders believe organizational actions caused the crisis. It goes unsaid that if the attribution of responsibility on the organization goes higher, the reputational threat will increase. More specifically, in the context of SCCT theory, three crisis clusters-which are in turn related to certain types of crisis-have been identified. In the first cluster-known as victim cluster-there is a very weak attribution of crisis responsibility; in fact, the company is observed as a victim of the occurrence. Usually, natural disasters, rumor, and workplace violence are categorized as such crises. The second cluster, instead, is defined as and characterized by a minimal attribution of crisis responsibility. The crisis event is here considered as unintentional or uncontrollable by the organization-e.g., technical-error accident, technical-error product. Finally, the intentional cluster, which views a strong attribution of the event on the organization-e.g., human-error accident, organizational misdeed. A list with some examples of crisis grouped by crisis clusters can be arranged as follows:

Victim cluster (the organization is also a victim of the crisis; weak attributions of crisis responsibility and mild reputational threat):

- natural disaster-acts of nature damage an organization such as an earthquake;

- rumor-false and damaging information about an organization is being circulated;

- workplace violence_current or former employee attacks current employees onsite; and

- product tampering/malevolence-external agent causes damage to an organization.

Accidental cluster (the organizational actions leading to the crisis were unintentional; minimal attributions of crisis responsibility and moderate reputational threat):

- challenges - stakeholders claim an organization is operating in an inappropriate manner;

- technical-error accidents—a technology or equipment failure causes an industrial accident; and

- technical-error product harm-a technology or equipment failure causes a product to be recalled.

Preventable cluster (the organization knowingly placed people at risk, took inappropriate actions or violated a law/regulation; strong attributions of crisis responsibility and severe reputational threat):

- human-error accidents-human error causes an industrial accident;

- human-error product harm—human error causes a product to be recalled; 
- organizational misdeed with no injuries—stakeholders are deceived without injury;

- organizational misdeed management misconduct-laws or regulations are violated by management; and

- organizational misdeed with injuries, stakeholders are placed at risk by management and injuries occur.

The second factor-crisis history—concerns whether the organization has previously experienced crises of similar nature. In this sense, the attribution theory suggests that when an organization undergoes crises of a similar nature on multiple occasions, then it must have some ongoing problems that need to be addressed. If these issues are not addressed, then there could be negative repercussions when considering the third factor, prior relational reputation. Prior relational reputation consists of how well or poorly an organization is perceived to have treated its stakeholders before. Both the last two elements can work as intensifiers for the degree of initial crisis responsibility: if the company has a bad history, then the company will be likely to be attributed more responsibility for the crisis. As previously stated, these three interconnected elements become of use to crisis managers in assessing the reputational threat that a crisis can pose to the company. Here, the three factors are combined in a process of assessment consisting of two phases.

Firstly, managers try to determine the type of crisis that their company ended up in; according to SCCT, each crisis type generates specific and predictable levels of crisis responsibility. By identifying the crisis type, managers will be able to anticipate the extent to which stakeholders initially hold the company responsible for the outbreak of the crisis. Secondly, crisis history and prior relationship reputation-the two intensifying factors of initial crisis responsibility-are considered, as they can alter the initial reputational threat: greater crisis responsibility will be attributed to the company that already experienced analogous occurrences in the past, while the company whose reputation has never been tarnished similarly before will not suffer as much. It was affirmed by Coombs [1] that the reputational threat deriving from an accidental crisis can escalate into the degree of intentional crisis when similar preconditions are there, as they can trigger stronger feelings of hatred toward the company. After identifying the reputational threat, managers must create their own crisis response strategies. As reiterated on several occasions earlier in the composition, even for the major experts of the field, it is inconceivable to craft a list of response strategies that can be referred to in any crisis situation. In this sense, SCCT presented a groundbreaking approach to crisis communications, as it made crystal clear that there should be a theoretical link between the type of the crisis and the response strategies adopted to put the fire out. For example, the response needs to be dictated by the degree of responsibility which the company is attributed during a crisis; still, as response strategies are pivoted on the organization's perceived acceptance of responsibility for the crisis, managers need to be extremely careful, as resorting to inappropriate responses may lead to worsened reputational damage. The more accommodative response strategiese.g., to show greater concern for the victims — can lead stakeholders to believe that the organization is taking on the responsibility for the whole matter. Additionally, SCCT suggests that response strategies can be grouped into three different typologies on the basis of the organization's perceived acceptance of responsibility for the crisis-e.g., denial, diminish, and rebuild. A list of SCCT crisis response strategies will now be presented, following which some insights about them will be discussed. 
Deny crisis response strategies are:

- attack the accuser-crisis manager confronts the person or group claiming something is wrong with the organization;

- denial—crisis manager asserts that there is no crisis; and

- scapegoat—crisis manager blames some person or group for the crisis.

Diminish crisis response strategies are:

- excuse-crisis manager minimizes organizational responsibility by denying intent to do harm and/or claiming inability to control the events that triggered the crisis; and

- justification-crisis manager minimizes the perceived damage caused by the crisis.

Rebuild crisis response strategies are:

- compensation_crisis manager offers money or other gifts to victims; and

- apology—crisis manager indicates the organization takes full responsibility for the crisis and asks stakeholders for forgiveness.

Bolstering crisis response strategies are:

- reminder-crisis manager tells stakeholders about the past good works of the organization;

- ingratiation-crisis manager praises stakeholders and/or reminds them of past good works by the organization; and

- victimage-crisis manager reminds stakeholders that the organization is a victim of the crisis too.

Deny crisis strategies seek to disconnect the organization from the crisis, as if it is not involved, it is unlikely to suffer from it. Still, in some types of crisis, such as rumor and challenge, managers are called to argue that there is no real crisis. If stakeholders embrace the version of crisis managers, then the organization is spared any reputational damage.

Diminish crisis strategies instead attempt to prove that a crisis is not as bad as stakeholders believe, or that organizational mismanagement was not among the underlying causes. If managers succeed in diminishing the involvement of the organization in the outbreak of the crisis-i.e., they lead stakeholders to believe that responsibility is not on the company-then the harmful effects are reduced. In order to achieve this, solid evidence is required as stakeholders will be given a number of frames-or versions-differing from the organization, from which they will select the one that they find as more plausible.

Such strategies are mostly used to mitigate the damages of crises constituting serious reputational threats, i.e., intentional crises, or crises that are of a similar nature to previous ones. Similar to rebuild strategies are bolstering response strategies, which are used to develop the organization's reputational asset, although 
only to a minor extent. Bolstering strategies base more upon the past relationships between the company and its stakeholders; for instance, the bolstering strategy "reminder" draws on back past good deeds in order to counterbalance the adverse effects from the present crisis. Essentially, bolstering functions as an additional strategy in order to support the aforementioned strategies. It was determined that communications can affect perceptions and change the way people think of the organization. If, on the one hand, the deny strategy turns out to be of use exclusively if stakeholders are convinced that there is no crisis, on the other hand, adjusting information, e.g., to express concern for the victims, and rebuilding the strategy find more ground for application and are the most effective ways to lessen the damage resulting from reputational threats.

Considering how well they address victims, rebuild strategies may be seen as the most logical response to crisis. However, they are not always the optimal solution for a number of reasons. First of all, it was demonstrated that they are usually more expensive. Secondly, overly accommodative strategies bring no greater reputational benefits; in fact, they can actually worsen the situation as stakeholders may be led to believe that the company is even more involved in the crisis than what was originally thought. To sum up, a list of crisis response strategies recommendations will be now presented:

- informing and adjusting information alone can be enough when crises have minimal attributions of crisis responsibility (victim crises), no history of similar crises and a neutral or positive prior relationship reputation;

- victimage can be used as part of the response for workplace violence, product tampering, natural disasters, and rumors;

- diminish crisis response strategies should be used for crises with minimal attributions of crisis responsibility (victim crises) coupled with a history of similar crises and/or negative prior relationship reputation;

- diminish crisis response strategies should be used for crises with low attributions of crisis responsibility (accident crises), which have no history of similar crises, and a neutral or positive prior relationship reputation;

- rebuild crisis response strategies should be used for crises with low attributions of crisis responsibility (accident crises), coupled with a history of similar crises and/or negative prior relationship reputation;

- rebuild crisis response strategies should be used for crises with strong attributions of crisis responsibility (preventable crises) regardless of crisis history or prior relationship reputation;

- the deny posture crisis response strategies should be used for rumor and challenge crises, when possible; and

- maintaining consistency in crisis response strategies.

Mixing deny crisis response strategies with either diminish or rebuild strategies will erode the effectiveness of the overall response. In spite of the fact that the whole theory bases on the specific crisis event, some limitations in the crisis response strategies provided by SCCT exist. In this sense, financial resources are the dominant constraints as some companies might not be able to afford or finance a particular crisis response, having then to resort to a less preferred strategy. 
Yet, SCCT is among the best frameworks that managers have at their disposal to protect corporate reputation at crisis times, and this is due to the fact that it originates from and incorporates the psychology of the stakeholders.

Overall, crisis type, crisis history, and prior relationship reputation help understanding how stakeholders will react to the crisis situation. Managers will be able to draw upon from that, and outline recommendations that best fit the particular crisis context. To give an example, some elements belonging to the SCCT framework will now be applied to the case of En+/RUSAL. In the first press announcement after the inclusion of RUSAL in OFAC list, En+ [7] reported that it was searching for a solution, while fulfilling its existing commitments. Then, as it was seen, pressure from several U.S. economic partners and allies following the increased price of aluminum spurred OFAC into extending the sanctions relief General Licenses on En+/RUSAL. In addition, OFAC reaffirmed the reason which first led to sanctions imposition-i.e., Deripaska's influence over En+. Although this was known from the beginning, it was now even more obvious that the best way for En+ to have sanctions lifted might be to remove Deripaska from the organizational structure. Therefore, OFAC declarations not only led to the initiation of the "Barker Plan"aimed at forcing Deripaska out of his seat as majority shareholder of the Boardbut also hinted the preferable crisis communication strategy for the particular situation-i.e., scapegoating. In the second press release from April 27, En+ [7] let stakeholders know that Deripaska agreed in principle to the conditions dictated by OFAC, and this became the leitmotif of En+ crisis communication; indeed, in all the following press releases, it was always made clear that efforts to reduce the relevance of Oleg Deripaska-i.e., the expedient used by OFAC to justify sanctions imposition-were being carried out. It is, however, curious that the choice of the scapegoat here did not come in response to the stakeholders' attribution of the situation, but was suggested by the opposing party itself. To conclude, the fact that Deripaska [7] commented the accusations moved against him only after sanctions were lifted suggests that he might have been instructed to do so, otherwise his crisis communication approach might have hindered En+'s, making it harder to have sanctions lifted in a short period of time. 


\section{Author details}

Alexander Rozanov ${ }^{1 *}$, Maria Ivanchenko ${ }^{1}$, Alexandra Baranova ${ }^{2}$, Mikhail Smirnov $^{2}$, Olga Belyaeva ${ }^{2}$, Alexander Barannikov ${ }^{2}$, Mikhail Ilichev ${ }^{3}$, Ludmila Ilicheva ${ }^{2}$, Biyaslan Tambiev², Maria Krotovskaya ${ }^{2}$, Vladimir Chilingaryan ${ }^{1}$, Tatiana Grabovich ${ }^{4}$, Zaru Dulatkyzy ${ }^{5,6}$, Alla Nikolaeva ${ }^{7}$, Svetlana Ivanova ${ }^{7}$, Kwame Boateng ${ }^{8}$, Mattia Masolletti ${ }^{9}$, Marina Danilina ${ }^{10}$, Dmitry Medvedev ${ }^{11}$ and Natalya Ogneva ${ }^{12}$

1 NUST MISIS, Moscow, Russian Federation

2 Russian Academy of National Economy and Public Administration, Moscow, Russian Federation

3 All-Russian Academy of Foreign Trade, Moscow, Russian Federation

4 MGIMO, Moscow, Russian Federation

5 Lomonosov Moscow State University, Moscow, Russian Federation

6 Lomonosov Moscow State University, Kazakhstan

7 Moscow State University of Psychology and Education, Moscow, Russian Federation

8 NUST MISIS, Ghana

9 NUST MISIS, Italy

10 Plekhanov Russian University of Economics, Moscow, Russian Federation

11 Gubkin Russian State University of Oil and Gas, Moscow, Russian Federation

12 Immanuel Kant Baltic Federal University, Kaliningrad, Russian Federation

*Address all correspondence to: rozanov-88@list.ru

\section{IntechOpen}

(C) 2020 The Author(s). Licensee IntechOpen. This chapter is distributed under the terms of the Creative Commons Attribution License (http://creativecommons.org/licenses/ by/3.0), which permits unrestricted use, distribution, and reproduction in any medium, provided the original work is properly cited. (cc) BY 


\section{References}

[1] Coombs WT. Protecting organization reputations during a crisis: The development and application of situational crisis communication theory. Corporate Reputation Review. 2007;10(3):163-176

[2] Tucker L, Melewar TC. Corporate reputation and crisis management: The threat and manageability of anticorporatism. Corporate Reputation Review. 2005;7(4):377-387

[3] Business dictionary. Uncertainty. Available from:http://www. businessdictionary.com/definition/ uncertainty.html [Accessed: 27 March 2019]

[4] European Parliament. EU sanctions: A key foreign and security policy instrument. Available from: http:// www.europarl.europa.eu/RegData/ etudes/BRIE/2018/621870/EPRS_ BRI(2018)621870_EN.pdf [Accessed: 27 March 2019]

[5] Mitroff II. Effective crisis management. The Academy of Management "EXECUTIVE". 1987;1(3):283-292

[6] RUSAL. RUSAL and the Ministry of Health of the Russian Federation announce completion of the vaccination against Ebola with a Russian vaccine [Press release]. 2018. Available from: https://rusal.ru/en/press-center/pressreleases/23846/ [Accessed: 22 February 2019]

[7] En+ Group. En+ Group comments on the OFAC designation, general licenses, GDR programme, Director resignation [Press release]. 2018. Available from: https://www. enplusgroup.com/en/investors/ regulatory-news-service-and-filings/ en-group-comments-on-the-ofacdesignationgeneral-licenses-gdrprogramme-director-resignation/ [Accessed: 23 February 2019]
[8] Selden Z. Economic Sanctions as Instruments of American Foreign Policy. Westport, Connecticut: Praeger Publishers; 1999

[9] U.S. Department of the Treasury. Treasury extends winddown period for united company RUSAL PLC [Press release]. 2018. Available from:https:// home.treasury.gov/news/press-releases/ sm0365 [Accessed: 23 February 2019]

[10] OFAC Sanctions List Search. Availablefrom: https://sanctionssearch. ofac.treas.gov [Accessed: 10 May 2019]

[11] U.S. Department of Treasury. Andrea M. Gacki, Director of Office of Foreign Assets Control to Mitch McConnell, Majority Leader of the U.S. Senate [Press release]. 2018. Available from: https://www.treasury. gov/resource-center/sanctions/OFACEnforcement/Documents/20181219_ notification_removal.pdf [Accessed: 20 March 2019]

[12] Chia K,Ritchie M. Aluminum seen facing 'Doomsday' if RUSAL sanctions proceed. Bloomberg. 2018. Available from: https://www.bloomberg.com/ news/articles/2018-09-07/aluminumseen-facing-doomsday-ifu-s-rusalsanctions-proceed [Accessed: 23 February 2019] 



\title{
The Political Economy of Crisis Recovery
}

\author{
Mohammad Ferdosi
}

\begin{abstract}
The aftermath of the global financial crisis marked another stress test for welfare states and varieties of capitalism. More than ever before, governments were forced to consider substantial reforms to welfare provision and enact flexibility-enhancing measures in order to improve financial solvency and economic performance. The crash, however, was not only a regionally uneven process in its origins but also led to makeshift or uneven policy responses. As a result, the socioeconomic effects of the downturn and political reactions to it varied considerably among countries. Nevertheless, there have been some common trends in outcome measures. These have served to blur the dividing lines between different welfare states and production systems, so vividly captured in the mainstream political economy literature.
\end{abstract}

Keywords: worlds of welfare, varieties of capitalism, crisis, recovery, outcomes, divergence, convergence

\section{Introduction}

One of the most enduring areas of research in political economy has revolved around the clustering of developed countries into distinct political and economic systems. Commonly referred to as the 'worlds of welfare' and 'varieties of capitalism' approaches, these categorizations are based on the assumption that countries can be defined by the types and combinations of policies, institutions and ideologies they employ. The worlds of welfare approach focuses mainly on differences in the structures of welfare states by examining their extent of decommodification, social stratification and the roles of the state, market and family in defining and responding to social needs. The varieties of capitalism approach emphasizes how diverse systems of production offer different types of comparative advantages, which help sustain divergent models of capitalism. Both typologies, therefore, not only assume that developed countries can be categorized into different types of welfare regimes and production systems, but that each welfare or production model follows a qualitatively different development trajectory, producing different types and degrees of outcomes as compared to other models, even in times of economic crisis.

This chapter seeks to test divergent theories of welfare development and varieties of capitalism by examining the extent to which different types of welfare states and production regimes exhibit markedly different socio-economic outcomes in the face of external pressures. We seek to raise a series of questions about divergent 
theories of national development within the context of crisis management and recovery. According to the literature, distinct welfare arrangements and production systems should produce qualitatively different outcomes, even in times of crisis, but is there enough empirical evidence to support such claims? It is also postulated that countries categorized under the same type of welfare and production model should display similar outcomes, but can we expect to find any national outliers within any of the distinct regime-clusters? Moreover, were some welfare states and market economies better able to return to their pre-crisis levels more than others? Or did all countries move in a broadly similar direction and experience a general worsening of outcomes in the post-crisis period?

To answer these questions, we begin the following section with a discussion of path dependent development and continuity in national distinctiveness. These concepts correspond with two main arguments found in the literature about divergence in national models of welfare and capitalism. Next, the two path-dependent arguments that distinguish between different welfare production systems are described in some detail. This is a followed by a brief discussion of the theory of convergence, which stands in contrast to theories emphasizing national diversity. We then discuss the sample of countries, socio-economic indicators and time period included in our datasets. In what follows, we summarize and analyze cross-national data on nine indicators. Finally, we end with some concluding remarks about cross-national divergence and convergence in socio-economic outcomes and whether the type of welfare production regime various countries had made much of a difference in the way their economies performed during the recent crisis.

\section{Path dependence}

The literature on path dependency emphasizes multiple pathways of national development, the persistence of institutional arrangements and continuity. In simple terms, path dependence means as time progresses meaningful change becomes more difficult to implement. In the political science literature, path dependence is used to refer to political trajectories that are resistant to change due to the self-enforcing nature of institutions [1]. In comparative political economy, path dependence is usually a reference to the persistence (inertia) of historically entrenched institutions, or the idea that variations in the size, structure and outcomes of welfare regimes are a consequence of the individual paths each one follows. In such a context, welfare states are viewed as diverse and resistant to change. Their development trajectories have become 'locked-in' over time making shifts away from them difficult, even in the face of common external pressures, which others view as driving all countries toward the same practices and outcomes. This has led to a debate over whether welfare and production systems are converging toward a similar model due to common pressures, or whether the path-dependent nature of institutional development continues to exist and reinforce the diversity of national trajectories. In general, support for the latter argument can be found in comparative studies based on typologies of the welfare state and market economy, which are reviewed below.

\section{Worlds of welfare}

Esping-Andersen's three worlds of welfare capitalism model is perhaps the most famous typology of welfare states [2]. For many years, comparative welfare scholarship has used his typology to categorize the welfare state according to three 
dimensions: decommodification (or the extent to which market dependency is reduced through state entitlements), the modes of social stratification (the idea that regime types manifest variable degrees of inequality) and the relationship between the state, market and/or family in the production and management of social wellbeing (a balance that typically varies across countries). This classification scheme is supposed to allow us to identify dimensions of variation within welfare regimes, dimensions that are explicit and narrow enough to be operationalized in an assessment of three ideal welfare cases - the typical liberal, conservative-corporatist and social democratic welfare regime-types.

The liberal welfare state provides a minimum level of social protections for its citizens. This is done in order to maximize market forces. Liberal regimes emphasize personal responsibility in welfare provision and deservingness for market relief. As a result, benefits are set low, social assistance is means-tested, and wage bargaining systems are decentralized so that the private sector can expand to its full potential. Liberal regimes try to ensure all who can work do so and obtain their income through participation in the free market. Social policy is therefore aimed at maximizing the market and individual independence. In such a model, a system of administrative surveillance monitors and enforces eligibility determinations for social assistance. Consequently, less than those who are eligible for relief end up receiving benefits. In general, liberal welfare states are said to have lower levels of public sector employment, direct job creation, social protection expenditures, long-term unemployment, union density and collective bargaining and higher levels of involuntary part-time work, marginally attached workers and short-term job tenure. The United States is considered the prototypical example of the liberal welfare regime [3].

The conservative-corporatist welfare regime is based on two different kinds of fragmentation in the provision of welfare. The first one entitles narrowly defined groups with their own specific benefits, with occupational and employment status playing an important role in the type or level of services provided. The second one provides welfare provision according to a perceived need for assistance using a measurable criterion. In general, traditional families are the main targets of welfare services, as social policy rewards breadwinners, and provides greater benefits to larger families. In this way, the conservative-corporatist welfare state promotes and sustains the position of the traditional family in society. Both types of fragmentation (occupation/employment and family) aim to preserve existing social structures and hierarchies. In this way, social benefits are not universal (equal for all), they tend to depend on past employment contributions, and financing is made possible through employer-employee payroll taxes rather than general tax revenues. Market forces are constrained to the extent that firms consider the interests of different shareholders in their business calculations. This helps maintain the 'social market' (diverse stakeholder economy). Conservative-corporatist welfare regimes generally feature medium levels of public sector employment, direct job creation, social protection expenditures, long term unemployment, union density and collective bargaining and lower levels of involuntary part-time work, marginally attached workers and short-term job tenure [3]. Germany is considered a primary example of the conservatist-corporatist welfare regime.

The social democratic welfare state tends to provide entitlements that are more universal in scope, egalitarian in their distributive goals and generous in their benefit levels. In this regime type, social rights provide high levels of decommodification and defamilialization in order to sustain social solidarity rather than reinforce hierarchical divisions or market forces. As the ideal welfare model, it supports the individual and family over the life course in order to make it easier for people to transition between life roles while dealing with challenges associated with 
work and/or parenthood. Such welfare states provide a range of cradle-to-grave protections for their citizens, including such things as child allowances, early childhood education, training policies, job protection, paid maternity leave, day care for preschoolers, wage replacement benefits, retirement pensions and home care for seniors. Social expenditures are typically financed through higher rates of taxation, with redistribution of additional income achieved via wealth taxation. Social democratic welfare states are said to have the highest levels of public employment, direct job creation, social protection expenditures, long-term unemployment (due to generous benefits), union density and collective bargaining and the lowest levels of involuntary part-time work, marginally attached work and short-term job tenure. Sweden is viewed as the main example of a social democratic welfare regime [3].

The southern European welfare regime was added to the three-fold typology above due to some developed countries exhibiting characteristics that distinguished them from other regime types $[4,5]$. The distinctive regime properties of the southern welfare state include familism, strong kindship networks, Catholicism, agricultural production and a fragmented system of welfare provision. Generally, the southern welfare state is said to have medium or lower levels of public employment, direct job creation, social protection expenditures, long-term unemployment, involuntary part-time work, marginally attached work, short job tenure, union density and collective bargaining. Spain is conventionally regarded as an example of the southern European welfare regime [3].

Significant debate has occurred over the extent to which countries actually fit into one of the ideal typical welfare regime models. Supporters of the typology view it as a valid and reliable methodological approach for categorizing mature welfare states and explaining cross-national similarities and differences between them. Others are much more skeptical. They criticize the typology [6] for its alleged inexhaustiveness (may be more than three or four ideal types), inexclusiveness (more anomalous cases than admitted), methodological soundness (wrong criteria and unsuitable operationalizations, variables and methods), lack of explanatory power [7] and usefulness in comparative analysis [8]. More sympathetic critics, however, admit significant differences in national political contexts exist among countries, particularly variations in institutional configurations, societal cleavage patterns, pressure of socio-economic forces, actor-constellations and degree of dependence on the state, market and family. These recognitions are generally based on contributions that delineate differences in government expenditures, ideological orientations, institutions, and formal policy elements $[9,10]$. The issue is that these aspects of welfare development fail to capture the outcomes of policies and institutions in practice. It is therefore important to take into account socio-economic effects in order to show how people fare under different welfare regimes and where regimes-types diverge and overlap in terms of real-life impacts [11]. While difficulties certain exist in making causal connections between different welfare arrangements and social outcomes, an outcome-centred approach nevertheless offers a unique vantage point to examine similarities and differences both between and within welfare regimes, which policy-focused and state-centred research has so far failed to adequately capture [12].

This is not to deny, of course, there may be a deep and important connection between policy, institutions and socio-economic outcomes. For instance, it may be that variations in social policy and levels of expenditure and the way institutional arrangements have developed in different countries are directly correlated with noticeable differences in their welfare outcomes and that countries, with highly diverse and unique configurations of capitalist political-economic institutions, cluster around a range of redistributive effects. In this way, variations in the socioeconomic outcomes observed, then, should be explainable with reference to the 
characteristics of the regime type in question. Moreover, countries associated with a particular regime-type should all exhibit similar outcomes and follow similar development paths.

Still, the question of whether and to what extent measures of socio-economic outcomes between different countries vary significantly with the regime-type has been relatively under researched in the literature. The little research that does exist has tended to focus on the micro level, the pre-crisis period and few cases and indicators. What is needed is an empirical assessment of outcomes across a large number of country cases during a period of external shock like the 2007-2008 crisis, which put intense pressure on public budgets, forcing many countries to restructure their welfare states $[13,14]$.

External and internal pressures do not necessarily determine the trajectories of welfare states, neither do they dictate their capacities to achieve desired goals in a uniform way. But they can restrict the possibilities and choices welfare states have at their disposal. Such modifying pressures toward conformity can include demographic changes, changing household and family patterns, the growth of non-standard employment arrangements, structural unemployment, technological changes, international competition, mobility of capital, international trade, participation in a common currency, globalization and economic crises [15]. These pressures can come in different forms and welfare states may react to them differently. But exactly how they affect the socio-economic outcomes of different welfare regimes remains an under-researched area.

Arguably, periods of economic crisis impose challenges and constraints that are somewhat different and perhaps more important than some of the other pressures on the welfare state. However, economic crises also tend to affect countries differently because of the diverse political-economic capacities and varied vulnerabilities of welfare regimes to such external shocks. Certainly, the global financial crisis of 2007 marked a 'stress test' for many welfare states [16] as more than ever before policymakers were forced to consider cuts in welfare provision and enact flexibilityenhancing measures in order to improve financial solvency and economic performance [17]. Adding to this challenge was the fact that the recent financial crisis, much like the recession of the early 1990s, occurred when many countries were already suffering from an economic downturn $[13,14]$.

Given the significant pressures the recent crisis placed on many welfare states, it is worth examining whether the boundaries between them have been fundamentally redrawn. For instance, did the crisis produce similar socio-economic outcomes in different regime types? Or, have there been notable and systematic differences in outcomes and patterns of continuity across welfare models in the years following the worst moments of the crisis? To what extent do the levels and distribution of welfare, as measured by certain outcomes, separate countries from each other? Countries within a regime cluster should not only be different enough as a regimetype to distinguish them from other countries, but also have outcomes in common. In this sense, within-regime coherence is just as important as between-regime differences [18].

\section{Varieties of capitalism}

Similar to the typology of welfare states, the varieties of capitalism framework popularized by Hall and Soskice [19] highlights systematic differences in the structural characteristics of countries. However, unlike welfare regime theory, it uses market and strategic coordination to differentiate national systems. According to the varieties of capitalism theory, domestic business coordinating capacity is a 
crucial factor in understanding the divergent structures, strategies and outcomes of countries. Configurations of national institutions are supposed to function in a complementary manner in order to produce different comparative advantages in innovation and production systems at the national level. As such, the business firm is placed at the center of the varieties framework, with actors formulating their decisions within the framework of institutions such as corporate governance systems, training regimes, wage setting and employee representation, labor legislation and the character and level of coordination between firms. These firms are connected to specific institutional arrangements. They have discretionary powers to make different decisions, but they tend to do so in ways that complement specific production models and competitive advantages. The concept of institutional complementarity is essential to the varieties approach. Complementarity is present when the existence or efficiency of one institution increases the returns from another [19].

The varieties approach is based on a comparison between two ideal types of capitalism - the liberal market economy and the coordinated market economy. In a liberal production regime, market-based mechanisms are maximized, with firms competing and coordinating according to supply and demand factors shaped by exchange rates of products and market actors. In a coordinated regime, nonmarket-based relations play an important role, as firms engage with each other in more collaborative ways, achieving coordination via partner networks and other institutionalized arrangements. Liberal economies are defined by an outsider corporate governance system, which promote general skills whereas coordinated economies are framed by an insider system of corporate finance, instead favoring vocational training programs and specific skills for long-term employment relationships. The varieties framework complements welfare-regime explanations insofar as liberal market economies and liberal welfare states overlap, while coordinated economies can be embedded within social democratic and conservative welfare regimes [20].

A third type of production system, the Mediterranean economy, is presented as a hybrid between the market and coordinated varieties of capitalism. It is characterized by specific kinds of non-market coordination in the area of corporate finance and more liberalized labor relations. Mediterranean economies are said to have a large agrarian sector and more extensive forms of state intervention in the economy. They sometimes have greater employment protections but lower decommodification rates and low product market competition with less short-term pressures for profits because of their centralized financial systems that can devalue national currencies. They also tend to have more limited qualifications that curb a high skill and wage strategy. The Mediterranean economy is said to overlap with the southern European welfare state [19].

Institutional divergence is emphasized in the varieties framework because of the recognition that there is no 'one size fits all' approach to capitalism. Different institutional configurations, themselves products of political development, culture and historical processes, support different production, market and investment strategies, resulting in different types of comparative advantages. Another important element in the varieties school is the recognition that firms make discretionary choices that are shaped by national institutional factors, which in turn influence, constrain and support those decisions. The varieties approach is therefore mainly concerned with the ways in which different types of economies co-exist, given their respective strengths and weaknesses in specific areas.

The varieties approach has been widely debated. It has been criticized for being too parsimonious for identifying only two types of economies or exaggerating the differences between them. Others claim it faces problems explaining changes over time $[21,22]$. There could be important processes common to both types of production regimes, which the varieties perspective not only fails to explain but 
also directs attention away from [23]. For example, it has been suggested that the varieties school cannot adequately account for economic restructuring processes as well as it can describe the institutional sources of comparative advantage [24]. Research has shown, for example, how different institutional arrangements have increasingly morphed into liberal governance systems in order to adapt to short term investor interests [25]. Other research suggests, however, that while internal and external pressures have not yet channeled different institutional configurations into a single converging and parallel model, there have been similar patterns of policy adoption across countries such as the transition from income provision to the promotion of market participation [26].

The global financial crisis has raised new questions about the persistence of cross-national differences identified by the varieties perspective. Sympathetic critics claim that convergence toward neoliberal and austerity policies in North America and Europe has diminished the differences within varieties of capitalism, but that path dependent development has nevertheless given way to divergent trends [27]. From this perspective, typical varieties of capitalism can change in degree 'from within', without necessarily transforming to another type of production system [28]. However, very little research has been conducted to assess the outcomes of different market systems over the crisis period as compared to institutional and policy trends [29]. This relatively neglected area can be used to uncover evidence of convergent or divergent trends between different production regimes.

The varieties approach has been used with some success to explain the empirical pattern of continuity and change in outcomes in different types of economies [30]. Scholars have used the typology to identify the micro processes of the relationship between institutional structures and certain policy outcomes. For example, one study sought to explain why trade union density and collective bargaining coverage have decreased in mainly liberal market economies but not so much in coordinated market economies [31]. Others have used the approach to make empirical claims about trends in labor market policies and outcomes such as employment protection, unemployment compensation and wages [32].

Most of the research in this area, however, has focused on a few socio-economic indicators, a minimum number of country cases, and the period before economic stagnation combined with recession put intense pressure on public budgets and increased the likelihood of negative labor market effects. More research is therefore needed to determine whether the labor market performance of the three archetypal forms of distinct capitalist systems conform to the expectations of the varieties of capitalism paradigm.

\section{Convergence}

Welfare states and varieties of capitalism are depicted as being more or less resilient to internal and external pressures. A number of studies have tried to show, for example, how the core institutional and policymaking characteristics of different welfare and production systems have remained firmly in place since the 1980s, even in the face of common pressures [33]. However, another body of comparative research has argued the opposite that different countries not only experience the same pressures but also in ways that lead them to converge toward a single organizational structure or pattern of output. The convergence theory holds that sociopolitical and structural changes, including globalization and economic crises [15] are homogenizing pressures that push all countries toward the same institutional logics, policies and/or outcomes. In this way, convergence is a process whereby differences between countries become less discernible over time. 
However, previous studies have paid more attention to institutions, policies and the ideas influencing policy-making than to socio-economic outcomes [34]. A more up-to-date and comprehensive study is therefore needed to determine the extent of convergence in the post-crisis period.

\section{Country cases, indicators, time period, limitations and measurements}

In what follows, we compare the outcomes of different welfare and production regime-types. The list of developed countries in the sample is grouped into four different types of welfare regimes and three different types of varieties of capitalism. Australia, Canada, Ireland, the United Kingdom and the United States are examples of the liberal welfare state and liberal market economy (LWS-LME). Austria, Belgium, Germany and the Netherlands are examples of the conservative-corporatist welfare state and coordinated market economy (CWS-CME). Denmark, Finland and Sweden are examples of the social democratic welfare state and coordinated market economy (SDWS-CME). And Greece, Italy, Portugal and Spain serve as examples of the southern welfare state and Mediterranean economy (SWS-ME) $[2,19]$.

We use the following nine indicators from the OECD database in order to compare the outcomes of 16 countries (clustered into four regime-types) before and after the recent crisis: public sector employment (employees in general government as a percentage of total employment), direct job creation (temporary work, and in some cases, regular jobs in the public or non-profit sector, offered to unemployed individuals), social protection expenditures (as a percentage of total expenditures), long term unemployment (share of unemployed as a percentage of the unemployed population), involuntary part time work (share of involuntary part-timers as a percentage of part-time employment, in dependent employment), marginally attached workers (those aged 15 and over, neither employed nor actively searching for work, but are willing to take up a job, as share of labor force), short-term job tenure (percentage of employees working for their employers for less than 1 year), trade union density (the ratio of wage and salary earners who are union members, divided by the total number of wage and salary earners) and collective bargaining coverage (number of employees covered by the collective agreement, divided by the total number of wage and salary earners) [35].

These nine indicators [36-44] were chosen for a variety of reasons. First, they were readily available for two points in time-one pre-crisis (2007) and one post-crisis (2017-2018) — for all the selected countries. Second, they are decent measures of socio-economic outcomes as they encompass a range of factors integral to macro-economic stability and social well-being. Third, they are easily accessible to a very broad audience. Fourth, they are measured regularly by the OECD, so they can be periodically updated to show further divergent or convergent trends beyond the most recent year for which data was available. Fifth, the choice of indicators was guided by an interest in processes connected to marginalization and social exclusion, given the type of welfare regime and variety of capitalism is supposed to be consequential for determining the relative inclusion and exclusion of certain groups in society. While some indicators do not capture the socio-economic position of large numbers of people, they are nevertheless important measures of social cohesion, which is an important social policy goal in all welfare and production regimes.

Making cross-country comparisons, however, is complicated by the differential impacts of the global financial and public debt crises. They did not affect all countries to the same extent and policy reactions and recovery processes have been very much unequal. In part, this is because of significant variations in financial 
and trade linkages and the practices and quality of other institutional factors such as exchange rate regimes and capital controls. The debt crises, for example, were prevalent in European countries, especially the Mediterranean region. Different regulatory settings, economic conditions, demographics and political factors all help determine both the level of vulnerability of welfare regimes and market economies to external shocks and the nature, direction and robustness of policy responses. This is one of the reasons why it is difficult to provide a single start date for the crisis or attribute crisis mitigation and recovery processes to the designs and capacities of specific types of welfare states and production models. Care should therefore be taken before generalizing across cases.

The pre- and post-crisis periods can be used as a test case to compare the socioeconomic outcomes of different welfare production systems. For this purpose, several indicators can be utilized to shed light on the extent of cross-national outcome convergence and divergence, which can be measured by comparing the: overall direction of change in the indicators (e.g., numeric outcomes improved or deteriorated), numerical values of the indicators (e.g., values very similar or different to each other), percent changes from one period to another, average country group scores, and average country group percent changes from one period to another (Table 1).

Public sector employment decreased in 12 out of 15 countries. The share of employment in general government ranged between 10.49 and $28.83 \%$ in 2017. In line with divergent expectations, the SDWS-CMEs had the highest rates of public employment (averaging 27.05\%), although they all experienced a small decline. Perhaps more surprisingly, the LWS-LMEs, CWS-CMEs and SWS-MEs all had similar rates and group averages, making them somewhat indistinguishable. However, there were small differences in the rates of the CWS-CMEs.

Direct job creation for the unemployed increased in seven countries, decreased in five countries and remained the same in three countries. Percent change increases ranged from 5.26 to $4100 \%$. Percent change decreases ranged between 6.12 and $100 \%$. While more countries had created public jobs for their vulnerable members since 2007, the 16 country group average in 2017 had declined by a change of $1.48 \%$. Unexpectedly, the group average of the CWS-CMEs had decreased by a change of $52.71 \%$ while the group average of the SWS-MEs had increased by a change of $241.54 \%$. Within-regime differences in rates were quite common.

Social protection expenditures increased in 10 out of 15 countries. Percent change increases ranged from 2.72 to $66.76 \%$. The group averages of all regimetypes except the LWS-LMEs increased in 2017. Contrary to expectations, the group averages of the SDWS-CMEs and LWS-LMEs were very similar in 2017 (36.06 and $33.56 \%$ ), despite these two regime-types representing opposite ends of the social expenditure spectrum in the worlds of welfare literature. Within-regime percentages were very similar among the LWS-LMEs and SDWS-CMEs, with most of them in the early to mid-30\% range. However, the rates among the CWS-CMEs varied considerably (ranging from 16.66 to $46.14 \%$ ). Similarly, the CWS-MEs all had very different rates (2.92, 8.37, 16.05 and 22.36\%) (Table 2).

The share of individuals out of work for 1 year or more increased in 12 out of 16 countries. Percent change increases ranged between 2.54 and $104.41 \%$. In 2018, the LWS-LMEs and SDWS-CMEs experienced an increase in their long-term unemployment rates and both regimes had very similar group averages (21.98 and $19.5 \%)$. While most CWS-CMEs saw their rates decrease in the post-crisis period, their group average (39.25\%) was higher than that of the LWS-LMEs and SDWSCMEs. There were significant within-regime differences in terms of rates among the LWS-LMEs, CWS-CMEs and SWS-MEs, showing once again divergent theories fail to account for dissimilar outcomes within particular regime-clusters. 


\begin{tabular}{|c|c|c|c|c|c|c|}
\hline $\begin{array}{l}\text { Indicator } \\
\text { year }\end{array}$ & $\begin{array}{c}\text { PSE } \\
2007\end{array}$ & $\begin{array}{l}\text { PSE } \\
2017\end{array}$ & $\begin{array}{c}\text { DJC } \\
2007\end{array}$ & $\begin{array}{l}\text { DJC } \\
2017\end{array}$ & $\begin{array}{c}\text { SPE } \\
2007\end{array}$ & $\begin{array}{l}\text { SPE } \\
2017\end{array}$ \\
\hline \multicolumn{7}{|c|}{ Liberal Welfare State \& Liberal Market Economy (LWS-LME) } \\
\hline Australia & N/A & N/A & 0.55 & 0.12 & 34.11 & 32.18 \\
\hline Canada & 19.13 & 19.38 & 0.01 & 0.01 & N/A & N/A \\
\hline Ireland & 14.61 & 14.86 & 1.02 & 1.24 & 37.61 & 35.19 \\
\hline UK & 19.2 & 16.01 & 0.0 & $0.01(2011)$ & 33.81 & 34.73 \\
\hline US & $15.89(2008)$ & 15.15 & 0.01 & 0 & 29.15 & 32.13 \\
\hline Averages & 17.21 & 16.35 & 0.318 & 0.276 & 33.67 & 33.56 \\
\hline \multicolumn{7}{|c|}{ Conservative Welfare State \& Coordinated Market Economy (CWS-CME) } \\
\hline Austria & 16.92 & 16.82 & 0.19 & 0.20 & 29.76 & 31.35 \\
\hline Belgium & 18.47 & 18.20 & 0.49 & 0.46 & 9.99 & 16.66 \\
\hline Germany & 11.33 & 10.49 & 0.83 & 0.21 & 49.23 & 46.14 \\
\hline Netherlands & 12.81 & 11.95 & 0.41 & 0.04 & 22.50 & 23.74 \\
\hline Averages & 14.88 & 14.36 & 0.48 & 0.227 & 27.87 & 29.47 \\
\hline \multicolumn{7}{|c|}{ Social Democratic Welfare State \& Coordinated Market Economy (SDWS-CME) } \\
\hline Denmark & 28.33 & 28.02 & 0.0 & 0.0 & 35.09 & 36.39 \\
\hline Finland & 24.59 & 24.29 & 0.56 & 1.09 & 26.75 & 32.53 \\
\hline Sweden & 30.26 & 28.83 & 0.0 & 0.0 & 41.06 & 39.26 \\
\hline Averages & 27.73 & 27.05 & 0.56 & 1.09 & 34.30 & 36.06 \\
\hline \multicolumn{7}{|c|}{ Southern Welfare State \& Mediterranean Economy (SWS-ME) } \\
\hline Greece & 17.99 & 17.70 & 0.01 & 0.42 & 7.48 & 2.92 \\
\hline Italy & 14.50 & 13.43 & 0.01 & $0.05(2015)$ & 16.49 & 22.36 \\
\hline Portugal & 14.49 & 14.38 & 0.0 & 0.0 & 12.66 & 16.05 \\
\hline Spain & 13.36 & 15.30 & $\begin{array}{c}0.24 \\
(2011)\end{array}$ & 0.42 & 6.86 & 8.37 \\
\hline Averages & 15.05 & 15.20 & 0.065 & 0.222 & 10.87 & 12.42 \\
\hline $\begin{array}{l}16 \text { Country } \\
\text { Averages }\end{array}$ & 18.12 & 17.6 & 0.271 & 0.267 & 26.17 & 27.33 \\
\hline
\end{tabular}

Table 1.

Public sector employment (PSE), direct job creation (DJC) and social protection expenditures (SPE) in worlds of welfare and varieties of capitalism.

The share of involuntary part-timers increased in 7 out of 13 countries. Percent change increases ranged from 19.75 to $157.41 \%$. Consistent with divergent theories, the LWS-LMEs and SWS-MEs had some of the highest rates (23.07 and 64.42\%), while the CWS-CMEs and SDWS-CMEs had the lowest (8.48 and 11.25\%). The sample group average increased by a change of almost $20 \%$.

The share of marginally attached workers decreased in eight countries, increased in six countries and remained the same in two countries. Country group averages were nearly indistinguishable in 2018, blurring the dividing lines between countries. There were notable differences among the LWS-LMEs, CWS-CMEs and SDWS-CMEs, particularly Australia, the Netherlands and Finland whose rates were more than twice that of their group members (Table 3).

The share of employees with less than 1 year job tenure decreased in nine countries and increased in six countries. Percent change decreases ranged between 3 and 
The Political Economy of Crisis Recovery

DOI: http://dx.doi.org/10.5772/intechopen.92586

\begin{tabular}{|c|c|c|c|c|c|c|}
\hline Indicator year & $\begin{array}{l}\text { LTU } \\
2007\end{array}$ & $\begin{array}{l}\text { LTU } \\
2018\end{array}$ & $\begin{array}{c}\text { IPTW } \\
2007\end{array}$ & $\begin{array}{c}\text { IPTW } \\
2018\end{array}$ & $\begin{array}{c}\text { MAW } \\
2007\end{array}$ & $\begin{array}{c}\text { MAW } \\
2018\end{array}$ \\
\hline \multicolumn{7}{|c|}{ Liberal Welfare State \& Liberal Market Economy (LWS-LME) } \\
\hline Australia & 18.5 & 19.4 & 23.8 & 28.5 & 7.1 & 5.5 \\
\hline Canada & 7.0 & 10.1 & N/A & N/A & 2.1 & 1.9 \\
\hline Ireland & 30.0 & 40.8 & 10.8 & $27.8(2017)$ & $0.8(2008)$ & 3.5 \\
\hline UK & 23.8 & 26.3 & 9.7 & 12.9 & $2.3(2008)$ & 1.2 \\
\hline US & 10.0 & 13.3 & N/A & N/A & 0.9 & 0.9 \\
\hline Averages & 17.86 & 21.98 & 14.77 & 23.07 & 2.64 & 2.60 \\
\hline \multicolumn{7}{|c|}{ Conservative Welfare State \& Coordinated Market Economy (CWS-CME) } \\
\hline Austria & 27.2 & 28.9 & 13.0 & 10.6 & 3.8 & 2.5 \\
\hline Belgium & 50.4 & 48.7 & 15.2 & 6.8 & 1.4 & 1.7 \\
\hline Germany & 56.6 & 41.4 & 21.6 & 9.9 & 1.6 & 1.3 \\
\hline Netherlands & 39.4 & 38.0 & 4.6 & 6.6 & 3.2 & 3.0 \\
\hline Averages & 43.40 & 39.25 & 13.60 & 8.48 & 2.50 & 2.12 \\
\hline \multicolumn{7}{|c|}{ Social Democratic Welfare State \& Coordinated Market Economy (SDWS-CME) } \\
\hline Denmark & 16.1 & 20.2 & 13.1 & 13.1 & 1.9 & 1.2 \\
\hline Finland & 23.0 & 22.8 & N/A & N/A & 3.3 & 4.6 \\
\hline Sweden & 12.8 & 15.5 & 13.1 & 9.4 & 2.1 & 1.7 \\
\hline Averages & 17.30 & 19.5 & 13.10 & 11.25 & 2.43 & 2.50 \\
\hline \multicolumn{7}{|c|}{ Southern Welfare State \& Mediterranean Economy (SWS-ME) } \\
\hline Greece & 49.7 & 70.3 & 61.6 & 78.6 & 0.9 & 2.4 \\
\hline Italy & 47.5 & 59.0 & 40.8 & 66.3 & $3.3(2010)$ & 3.6 \\
\hline Portugal & 47.2 & 48.4 & 54.7 & 53.5 (2017) & 1.3 & 2.5 \\
\hline Spain & 20.4 & 41.7 & 37.5 & 59.3 & 3.6 & 3.6 \\
\hline Averages & 41.20 & 54.85 & 48.65 & 64.42 & 2.27 & 3.02 \\
\hline $\begin{array}{l}16 \text { Country } \\
\text { Averages }\end{array}$ & 29.97 & 34.05 & 24.58 & 29.48 & 2.47 & 2.57 \\
\hline
\end{tabular}

Table 2 .

Long-term unemployment (LTU), involuntary part-time workers (IPTW) and marginally attached workers $(M A W)$ in worlds of welfare and varieties of capitalism.

$22.43 \%$. Percent change increases were from 0.92 to $89.42 \%$. Short-term job tenure rates were similar in the LWS-LMEs and SDWS-CMEs (close to $20 \%$ points), contrary to expectations. In the literature, the prevalence of flexible employment is said to be greater in the liberal economies. While short-term job tenure decreased in most places, at least 11 countries from four different regimes had rates between 16 and 22\%, meaning nearly one-fifth of all their employees were working for their employers for less than 12 months. These similar rates make the regime-clusters indistinguishable as well. There were also within-regime differences among the CWS-CMEs and SWS-MEs.

Trade union density decreased in 15 out of 16 countries. In eight countries, there were percent change decreases ranging between 15 and 30\%. Consistent with expectations, the LWS-LMEs and SWS-MEs had the lowest union density figures, with the CWS-CMEs and SDWS-CMEs coming in second and third place respectively. There were considerable outliers in all the regime-types except the SDWS-CMEs whose rates were similar. 


\begin{tabular}{|c|c|c|c|c|c|c|}
\hline $\begin{array}{l}\text { Indicator } \\
\text { year }\end{array}$ & $\begin{array}{l}\text { STJT } \\
2007\end{array}$ & $\begin{array}{l}\text { STJT } \\
2018\end{array}$ & $\begin{array}{l}\text { TUD } \\
2007\end{array}$ & $\begin{array}{l}\text { TUD } \\
2018\end{array}$ & $\begin{array}{l}\text { CBC } \\
2007\end{array}$ & $\begin{array}{l}\text { CBC } \\
2017\end{array}$ \\
\hline \multicolumn{7}{|c|}{ Liberal Welfare State \& Liberal Market Economy (LWS-LME) } \\
\hline Australia & 24.7 & $\begin{array}{c}20.9 \\
(2017)\end{array}$ & 18.8 & 13.7 & 54.9 & $60.0(2016)$ \\
\hline Canada & 22.8 & 20.6 & 27.3 & 25.9 & 29.4 & 28.1 \\
\hline Ireland & 20.0 & 19.4 & 30.5 & 24.1 & 40.5 (2009) & $32.5(2014)$ \\
\hline UK & 18.5 & 16.7 & 28.0 & 23.4 & 34.6 & 26.0 \\
\hline US & N/A & N/A & 11.6 & 10.1 & 12.7 & 11.60 \\
\hline Averages & 21.50 & 19.40 & 23.24 & 19.44 & 34.42 & 31.64 \\
\hline \multicolumn{7}{|c|}{ Conservative Welfare State \& Coordinated Market Economy (CWS-CME) } \\
\hline Austria & 16.5 & 17.0 & 30.4 & 26.3 & $98.0(2008)$ & 98.0 \\
\hline Belgium & 13.9 & 12.4 & 54.7 & 50.3 & 96.0 & 96.0 \\
\hline Germany & 15.6 & 14.8 & 19.8 & 16.5 & 61.7 & $56.0(2016)$ \\
\hline Netherlands & 10.4 & 19.7 & 20.2 & 16.4 & 79.1 & 77.6 \\
\hline Averages & 14.1 & 15.97 & 31.27 & 27.37 & 83.70 & 81.90 \\
\hline \multicolumn{7}{|c|}{ Social Democratic Welfare State \& Coordinated Market Economy (SDWS-CME) } \\
\hline Denmark & 27.2 & 21.1 & 69.0 & 66.5 & 76.8 & $82.0(2016)$ \\
\hline Finland & 21.8 & 22.8 & 70.6 & 60.3 & $84.7(2008)$ & $89.3(2015)$ \\
\hline Sweden & 21.6 & 21.8 & 70.8 & 64.9 & 89.5 & $90.0(2016)$ \\
\hline Averages & 23.53 & 21.90 & 70.13 & 63.90 & 83.66 & 87.10 \\
\hline \multicolumn{7}{|c|}{ Southern Welfare State \& Mediterranean Economy (SWS-ME) } \\
\hline Greece & 10.8 & 13.6 & 22.6 & $20.2(2016)$ & 100.0 & $25.5(2016)$ \\
\hline Italy & 12.7 & 12.2 & 33.5 & 34.5 & $80.0(2010)$ & $80.0(2016)$ \\
\hline Portugal & 14.5 & 16.6 & 20.7 (2008) & 15.3 (2016) & 86.0 & 73.9 (2016) \\
\hline Spain & 24.3 & 19.8 & 16.3 & 13.6 & 82.9 & 83.6 (2016) \\
\hline Averages & 15.57 & 15.50 & 23.27 & 20.90 & 87.22 & 65.75 \\
\hline $\begin{array}{l}16 \text { Country } \\
\text { Averages }\end{array}$ & 18.35 & 17.96 & 34.05 & 30.12 & 69.17 & 63.13 \\
\hline
\end{tabular}

Table 3.

Short-term job tenure (STJT), trade union density (TUD) and collective bargaining coverage (CBC) in worlds of welfare and varieties of capitalism.

Collective bargaining coverage decreased in eight countries, increased in five countries and remained the same in three countries. Group averages in 2017 were consistent with assumptions in the literature, although the SDWS-CMEs, CWS-CMEs and SWS-MEs had very similar averages in 2007. Within-regime differences were notable in all the regime-types except the SDWS-CMEs whose rates were similar.

\section{Conclusion}

Overall, there was unidirectional convergence toward negative outcomes in many countries in the post-crisis period. Many countries have not returned to their precrisis levels as several indicators show, including public sector employment (12 out of 15 countries experienced a decrease), direct job creation (decreased in 5 out of 15 
countries), social protection expenditures (decreased in 5 out of 15 countries), longterm unemployment (increased in 12 out of 16 countries), involuntary part-time work (increased in 7 out of 13 countries), marginally attached workers (increased in 6 out of 16 countries), short-term job tenure (increased in 6 out of 15 countries), union density (decreased in 15 out of 16 countries) and collective bargaining coverage (decreased in 8 out of 16 countries). Different welfare production systems were therefore not always distinguishable in terms of their impact on the overall direction of change, as many countries were worse off on almost every indicator after the crisis than before it, or the degree of change from 1 year to another, as some of the greatest negative percent changes were reported among the least expected regime-types such as the SDWSCMEs. It also seems less plausible that the type of welfare or production regime makes as much difference in shaping the value of outcomes as some of the literature seems to suggest. This can be seen in very similar group averages for indicators such as public sector employment (with three regime averages ranging between 14 and 16\%), social protection expenditures (with two opposite regimes exhibiting averages between 33 and 36\%), long-term unemployment (two regimes had averages between 19 and 21\%), marginally attached workers (all four regimes had averages between 2 and 3\%), short-term job tenure (two regimes had averages between 19 and $21 \%$ and two regimes had 15\% averages) and trade union density (two regimes had averages between 19 and 20\%). Furthermore, individual countries belonging to the same regime cluster sometimes shared very little in common with their group members in terms of the direction of change and the value of the outcomes.

However, it is not implausible that the type of welfare or production regime makes some difference. This is most clearly demonstrated in the data by the way different types of welfare and production systems were characterized by different average levels of direct job direction, involuntary part-time workers and collective bargaining coverage. Overall, however, the empirical evidence seems to call into question between regime differences and within regime similarities as postulated by mainstream theoretical understandings of welfare states and varieties of capitalism. There appears to be more evidence of convergence than divergence in negative outcomes across the four regime clusters, as well as lack of evidence to support within-regime coherence.

\section{Author details}

Mohammad Ferdosi

McMaster University, Hamilton, Canada

*Address all correspondence to: ferdosim@mcmaster.ca

IntechOpen

(C) 2020 The Author(s). Licensee IntechOpen. This chapter is distributed under the terms of the Creative Commons Attribution License (http://creativecommons.org/licenses/ by/3.0), which permits unrestricted use, distribution, and reproduction in any medium, provided the original work is properly cited. (cc) BY 


\section{References}

[1] Pierson P. The path to European integration: A historical institutionalist analysis. Comparative Political Studies. 1996;29:123-163

[2] Esping-Andersen G. The Three Worlds of Welfare Capitalism. New Jersey: Princeton University Press; 1990

[3] Muffels R, Tsakloglou P, Mayes DG. Social Exclusion in European Welfare States. Cheltenham: Edward Elgar; 2002

[4] Leibfried S. Towards a European welfare state? On integrating poverty regimes into the European community. In: Ferge Z, Kolberg JE, editors. Social Policy in a Changing Europe. Frankfurt: Campus and Westview; 1992. pp. 245-279

[5] Ferrera M. The 'southern' model of welfare in social Europe. Journal of European Social Policy. 1996;6:17-37

[6] Ringen S. Households, standard of living, and inequality. Review of Income and Wealth. 1991;37:1-13

[7] Baldwin P. Can we define a European welfare state model? In: Greve B, editor. Comparative Welfare States: The Scandinavian Model in a Period of Change. London: Macmillan; 1996. pp. $29-44$

[8] Kasza GJ. The illusion of welfare 'regimes.. Journal of Social Policy. 2002;31:271-287

[9] Lewis J. Women and Social Policies in Europe. Aldershot: Edward Elgar; 1993

[10] Kautto M, Heikkila M, Hvinden B, Marklund S, Ploug N, editors. Nordic Social Policy: Changing Welfare States. London: Routledge; 1999

[11] Goodin RE, Headey B, Muffels R, Dirven $H$. The Real Worlds of Welfare Capitalism. Cambridge: Cambridge University Press; 1999
[12] Broadkin EZ, Marston G. Work and the Welfare State: Street Level Organizations and Workfare Politics. Washington: Georgetown University Press; 2013

[13] Bianchi S, Casper L, Peltola P. A cross-national look at married women's economic dependency. In: LIS Working Paper No. 143. New York: LIS; 1996

[14] Jenkins SP, Brandolini A, Micklewright J, Nolan B. The Great Recession and the Distribution of Household Income. Oxford: Oxford University Press; 2013

[15] Buti M, Franco D, Pench LR. Reconciling the welfare state with sound public finances and high employment. In: Buti M, Franco D, Pench LR, editors. The Welfare State in Europe: Challenges and Reforms. Cheltenham: Edward Elgar; 1999. pp. 7-42

[16] Atkinson T. A stress test for the welfare state. In: Hemerijck A, Knapen B, van Doorne E, editors. Aftershocks: Economic Crisis and Institutional Choice. Amsterdam: Amsterdam University Press; 2009. pp. 207-211

[17] Schomann I. Labour law reforms in Europe: Adjusting employment protection legislation for the worse? In: ETUI Working Paper 02. Brussels: ETUI; 2014

[18] Eikemo TA, Bambra C. The welfare state: A glossary for public health. Journal of Epidemiology and Community Health. 2008;62:3-6

[19] Hall PA, Soskice D. Varieties of Capitalism: The Institutional Foundations of Comparative Advantage. Oxford: Oxford University Press; 2001

[20] Huber E, Stephens JD. Development and Crises of the Welfare State: Parties 
and Policies in Global Markets. Chicago: University of Chicago Press; 2001

[21] Crouch C. Capitalist Diversity and Change. Oxford: Oxford University Press; 2005

[22] Jackson G, Deeg R. How many varieties of capitalism? Comparing the comparative institutional analyses of capitalist diversity. In: MPIfG Discussion Paper No. 06/2. Cologne: Max Planck Institute for the Study of Societies; 2006

[23] Pontusson J. Varieties and commonalities of capitalism. In: Coates D, editor. Varieties of Capitalism: Varieties of Approaches. Basingstoke: Macmillan; 2005. pp. 163-188

[24] Coates D. Varieties of Capitalism: Varieties of Approaches. Basingstoke: Macmillan; 2005

[25] Baccaro L, Howell C. Trajectories of Neoliberal Transformation: European Industrial Relations since the 1970s. Cambridge: Cambridge University Press; 2017

[26] Bonoli G, Natali D. The Politics of the New Welfare State. Oxford: Oxford University Press; 2012

[27] van Zon H. Globalized Finance and Varieties of Capitalism. Basingstoke: Macmillan; 2016

[28] Hay C, Wincott D. The Political Economy of European Welfare Capitalism. Basingstoke: Macmillan; 2012

[29] Theodoropoulou S. Labour Market Policies in the Era of Pervasive Austerity: A European Perspective. London: Policy Press; 2018

[30] Wailes N, Kitay J, Lansbury RD. Varieties of capitalism, corporate governance and employment relations under globalization. In: Marshall S, Mitchell R, Ramsay I, editors. Varieties of Capitalism, Corporate Governance and Employment Systems. Melbourne: Melbourne University Press; 2008. pp. 19-38

[31] Godard J. The new institutionalism, capitalist diversity and industrial relations. In: Kaufman BE, editor. Theoretical Perspectives on Work and the Employment Relationship. Champaign: IRRA; 2004. pp. 229-264

[32] Estevez-Abe M, Iversen T, Soskice D. Social protection and the formation of skills: A reinterpretation of the welfare state. In: Hall P, Soskice D, editors. Varieties of Capitalism: The Institutional Foundations of Comparative Advantage. Oxford: Oxford University Press; 2001. pp. 145-183

[33] Stephens JD, Huber E, Ray L. The welfare state in hard times. In: Kitschelt H, Lange P, Marks G, Stephens JD, editors. Continuity and Change in Contemporary Capitalism. Cambridge: Cambridge University

Press; 1999. pp. 164-193

[34] Starke P, Kaasch A, van Hooren F. The Welfare State as Crisis Manager: Explaining the Diversity of Policy Responses to Economic Crisis.

New York: Macmillan; 2013

[35] Organisation for Economic Co-operation and Development. OECD Glossary of Statistical Terms. Paris: OECD Publishing; 2008

[36] OECD. Public Sector Employment [Internet]. 2020. Available from: https://stats.oecd.org/index. aspx?queryid $=94403$ [Accessed: 28 October 2019]

[37] OECD. Direct Job Creation [Internet]. 2020. Available from: https://stats.oecd.org/Index. aspx?DataSetCode=LMPEXP [Accessed: 28 October 2019]

[38] OECD. Social Protection Expenditures [Internet]. 2020. Available 
from: https://stats.oecd.org/index. aspx?queryid= 82342 [Accessed: 28 October 2019]

[39] OECD. Long-Term Unemployment Rate [Internet]. 2020. Available from: https://stats.oecd.org/Index. aspx?DataSetCode=DUR_I [Accessed: 28 October 2019]

[40] OECD. Involuntary Part-Time Work [Internet] . 2020. Available from: https://stats.oecd.org/Index. aspx?DataSetCode=INVPT_I [Accessed: 28 October 2019]

[41] OECD. Marginally Attached Work [Internet]. 2020. Available from: https://stats.oecd.org/Index. aspx?DataSetCode=MA_I [Accessed: 03 January 2020]

[42] OECD. Short-Term Job Tenure [Internet]. 2020. Available from: https://stats.oecd.org/Index. aspx?DataSetCode=TENURE_FREQ [Accessed: 03 January 2020]

[43] OECD. Trade Union Density [Internet]. 2020. Available from: https://stats.oecd.org/Index.

aspx? DataSetCode=TUD\# [Accessed: 03 January 2020]

[44] OECD. Collective Bargaining Coverage [Internet]. 2020. Available from: https://stats.oecd.org/Index. aspx? DataSetCode=CBC [Accessed: 03 January 2020] 


\title{
Contagion, Exchange Rate, and Financial Volatility: Indonesian Case in Global Financial Turbulence
}

\author{
Telisa Falianty and Arif Budimanta
}

\begin{abstract}
Global turbulence after the financial crisis has hit Indonesia and almost all emerging countries. Quantitative Easing (QE) normalization (tapering of) has caused the capital outflows from emerging countries. Trade war and increasing geopolitical tension together raise the pressure. Argentina and Turkey have been experiencing economic shock. Indonesia should identify the contagion possibility and refer to Thai baht contagion experience in 1997. This paper assesses the contagion, exchange rate, and financial volatility triggered by global turbulence and Argentina-Turkey crisis in 2018. We use vector autoregression (VAR), simple correlation, dynamic conditional correlation (DCC), and regression method. We will investigate the potential contagion both in stock and exchange rate markets and in the rupiah exchange rate determination from both contagion and fundamental factors regarding the balance of payment (BOP) condition. The empirical result shows the potential contagion from Argentina and Turkey's financial crisis to the Indonesian economy, especially to the stock market and exchange rate. The regression and correlation result also shows that Turkey has a higher financial contagion effect than Argentina to Indonesian financial market. Balance of payment condition also has the significant effect to explain rupiah exchange rate depreciation.
\end{abstract}

Keywords: contagion, exchange rate, financial volatility, financial crisis, dynamic conditional correlation

\section{JEL Classification: F32}

\section{Introduction}

Many economists believe that the impact of the crisis comes not only because of the country's weak macroeconomic condition but also because of the interlinkage between the country and investor perception, which has played a bigger role in the emerging market economic crisis. This is proven by the great economic crisis in 1998 and 2008. The economic crisis that hit Southeast Asia and South Korea in 1998 was a dark past in the history of the global economy. The crisis that began in Thailand due to the difficulty in paying high foreign debt spread to various countries including Indonesia. Similarly, the economic crisis in 2008, which was triggered by the subprime mortgage crisis and the subsequent bankruptcy of Lehman Brothers in the United States, transmitted rapidly to Europe, Asia, and Latin America. 
As a country with a strong influence, every event that happened in the United States, including the policies taken by their government, can affect the global economic condition. In 2018, the United States decided to raise the benchmark interest rate which made the investment in developing countries look no longer attractive. The Federal Reserve's policy of raising interest rates put pressure on other countries to tighten their monetary policies and reduce US dollar liquidity. Various countries were affected, including Indonesia, but Argentina and Turkey were the worst.

Argentina has a long history of economic crisis [1]. In the period of the 1950s, Argentina experienced severe inflation, which reached 102\% in 1959. Their condition improved in the 1960s because of the global booming economy. Unfortunately, in 1975, Argentina's economy was poorly managed, so the inflation at that time reached 335\%. In 2001, local government policy brought Argentina to owe the IMF an amount of USD 132 billion. The economic condition of Argentina had not shown signs of improvement. In 2015, Argentina was hit by an economic crisis again. Under President Macri's leadership, the Argentine government was trying to hold capital out. The central bank raised interest rates to $40 \%$, recorded as the highest in the world today. This condition is exacerbated by the decision of the FED to continue to increase its interest rates, so that capital for emerging markets is likely to become more expensive and/or scarce. With an aim to be free of the crisis, the government turned to the International Monetary Fund (IMF) for $\$ 57.1$ billion or around Rp700 trillion (exchange rate of Rp14,000) in 2018 [2].

Apart from Argentina, the impact of the FED's decision to leave interest rates higher is also experienced by Turkey. Turkey's condition is no less severe than Argentina's because, in addition to the FED interest rate hike, their bad political relations with the United States have resulted in a trade war between the two countries. In 2018, Lira dropped $40 \%$ to the US dollar. There are at least three reasons why Turkey drowned in the current economic crisis [3]. First, Turkey has been experiencing the current account deficits in the 2000s. Turkey's current account deficit to gross domestic product (GDP) ratio was 5.6\% in 2017 and $6.7 \%$ during the first quarter of 2018. Second, the Turkish economy built on external debt and high expenditure deficits. Based on the data from the Bank for International Settlements (BIS), Turkey has debts to Spanish banks of USD 83.3 billion, French banks of USD 38.4 billion, Italian banks of USD 17 billion, Japanese banks of USD 14 billion, the UK banks of USD 19.2 billion, and the US banks of USD 18 billion. As a result of Turkey's debts with other countries using the dollar, when the dollar increases, the Turkish debt will continue to swell. Gross foreign debt as a share of GDP (\%) in Turkey increased from 36.7\% in 2011 to $52.9 \%$ in the first quarter of 2018. In the midst of a downturn in the global economy, it will be difficult for Turkey to pay its debts and finance its government expenses. Third, the Central Bank of the Republic of Turkey (CBRT) gross foreign currency reserves decreased from USD 112.0 billion in December 2013 to USD 78.3 billion in July 2018 and to USD 70.4 billion in August 2018, while Turkey's foreign currency need is an increase.

The crisis that occurred in Argentina and Turkey can have an impact on other developing countries. Reflecting on the previous experience, the government of Indonesia is careful in taking steps so that the impact of the crisis experienced by Argentina and Turkey does not have an impact on the economy of Indonesia (Figure 1).

Liberalization of capital flows in the past two decades and an increase in the scale of financial transactions across regions have increased exchange rate movements. This has an impact on exchange rate fluctuations in Indonesia. Since 2011, the rupiah has never returned to its lowest level, which has been around the 


\section{Movement of the Exchange Rate of Rupiah against}

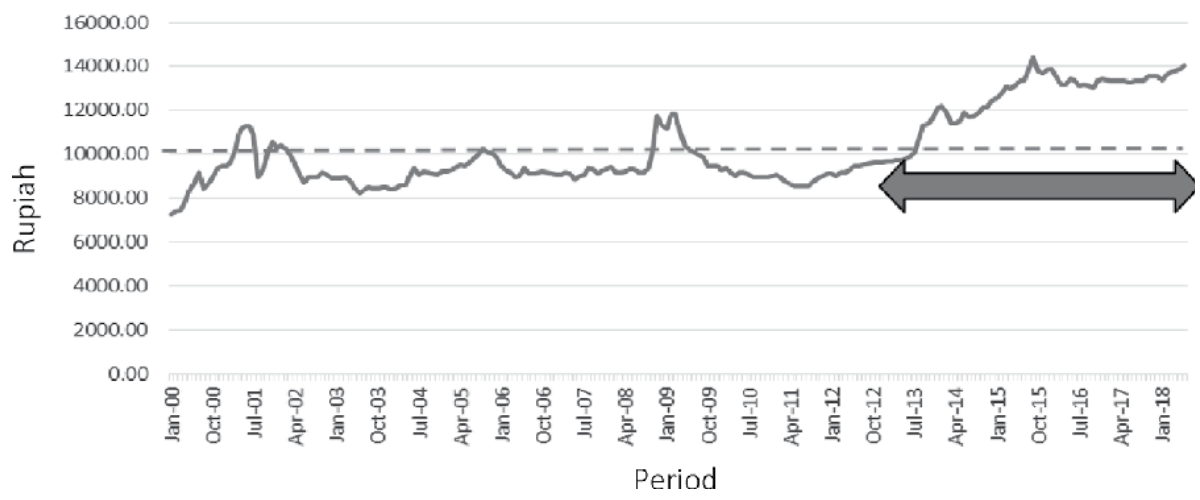

Figure 1.

Movement of the exchange rate of rupiah against the dollar. Source: Authors, 2019.

Rp8500. In the past 7 years, the rupiah has experienced a weakening trend. In the previous period, the rupiah can always return or have a stationary movement. In the periods of 2000-2001, the depreciation period occurred for 16 months, 2000-2003 for 24 months, and 2008-2009 for 10 months. From 2011 until today, the period of depreciation has occurred for three phases, namely, 32, 17, and 16 months. If it is accumulated (because there is at least a period of appreciation and is very thin), the period of depreciation has more or less happened for 65 months. There is no sign of when the rupiah will strengthen at least to the range of Rp12,000-13,000. This is still far from the average exchange rate in the last 18 years in the range of $\mathrm{Rp} 10,000$ per dollar. It can be concluded that this downturn period tends to be more persistent and longer. There is no sign that the rupiah can return to this balance in the near future (Figure 1).

The condition of the rupiah, which is still weakening, is due to Indonesia's current account deficit and a large and growing budget deficit. Indonesia's current account deficit in 2018 is $2.98 \%$, greater than the deficit in 2017, which reached $2.90 \%$ [4]. This has caused Indonesia to rely heavily on capital inflows and foreign debts, so that the crisis in other countries can trigger a capital outflow from Indonesia and a depreciation of the rupiah. The percentage of capital outflow in Indonesia's GDP continues to increase. In 2017, investments coming out of

\begin{tabular}{lccc}
\hline & Argentina & Turkey & Indonesia \\
\hline Current account to GDP & $-5.40 \%$ & $-6.1 \%$ & $-2.98 \%$ \\
\hline Exchange rate against US dollars & $-52 \%$ & $-40 \%$ & $-7.6 \%$ \\
\hline Government debt & USD 27,5827.96 billion & USD 466.7 billion & USD 295.7 billion \\
\hline GDP per capita & USD 11,652.57 & USD 11,114.3 & USD 4051.7 \\
\hline Debt ratio to GDP & $86.2 \%$ & $28.30 \%$ & $29.8 \%$ \\
\hline Economic growth Q2 2018 & $-4.7 \%$ & $7.22 \%$ & $5.27 \%$ \\
\hline Annual inflation & $47.1 \%$ (December 2018); & $15.85 \%$ & $3.18 \%$ \\
& $57.3 \%$ (May 2019) & & \\
\hline
\end{tabular}

Source: Trading Economics [5-7].

Table 1.

Comparison between Argentina, Turkey, and Indonesia. 
Indonesia reached $0.198 \%$ of GDP, while in 2018 , it increased to $0.607 \%$ [8]. Plus, the FED's policy to raise the interest rates is also a nightmare for Indonesia because investors will consider it more profitable to invest in the United States than Indonesia, which is a developing country with more vulnerable economic conditions (Table 1).

Compared to Argentina and Turkey in 2018, Indonesia's economic condition is still better than the two countries. Only three out of the seven indicators placing Indonesia worse than Turkey, namely, GDP per capita, debt ratio, and economic growth. For Argentina, Indonesia only worse in GDP per capita indicator. Even so, as a fellow developing country, empirical study regarding the contagion of the Argentina-Turkey crisis to the economics of Indonesia is needed to become the basis for future decision-making. Moreover, empirical studies that discuss the contagion of the crisis in Indonesia are still relatively minimal. For this reason, this research will discuss the potential transmission of the Argentina-Turkey crisis in 2018 to the Indonesian economy. This study aims to identify this potential contagion as well as to explain the exchange rate and financial volatility of Indonesian financial sector.

\section{Literature review}

There are diverse definitions of contagion. Contagion in this paper is defined as the transmission of crisis to a particular country due to its dependence or similarity with another country in crisis. This is in line with Dornbusch et al. [9] that state that contagion is the increasing correlation between countries after the crisis. Pericoli and Sbracia [10] and Forbes and Rigobon [11] define contagion as co-movements in asset prices and quantity across the market. Moreover, Masson [12,13] says that contagion is the transmission of local shocks to another country or another financial market. Based on those definitions, it can be concluded that contagion is the rise in cross-market linkage aftershocks, measured by movements together on asset prices and financial flows across the market $[9,11,14]$.

Kaminsky et al. [15] define contagion as an episode where there are significant effects that evolve over a matter of hours or days in a number of countries after an event. Meanwhile, Fratzscher [16] states that contagion is the transmission of a crisis to a particular country because of mutual financial and real interdependence with countries that have experienced a crisis. By using the vector autoregression (VAR) method, Fratzscher [16] concludes that there are two causes of financial interdependence between countries: (1) direct financial relations, that is, the fact that financial institutions may have large cross-border ownership, and (2) indirect financial relations, in particular the existence of common lenders and decisions by institutional investors, have received much attention in recent years [16].

Kaminsky et al. [15] observe the reasons for cross-border financial contagion occurred in some cases but not others. This paper emphasizes that there are three key elements that cause the contagion or commonly referred to as unholy trinity, that is, a sudden reversal in capital inflows, shocks, and contagion from creditors [15]. First, contagion is followed by a surge in international capital inflows, and the sudden initial announcement pricked the capital flow bubble. With rapid contagion, investors and financial institutions are exposed to the crisis of the country and ready to withdraw their investment on short notice [15]. Second, the announcement that triggered a chain reaction came as a surprise to the financial markets. The difference between anticipated and unanticipated events seems important because early warning allows investors to adjust their portfolios to limit the damage caused by the crises. Third, there are significant direct international consequences of creditor-be it commercial banks, hedge funds, mutual funds, or bondholders-spreading the 
crises across the national borders. Kaminsky et al. [15] explain that what happened in Asia in 1997 is an example of cross-border contagion. The Asian countries accounted for $65 \%$ of the emerging market loan portfolio of Japanese banks [15]. Because of the floatation experienced by Thai baht in 1997, the Japanese banks retrenched quickly and cut credit lines to emerging Asia. This happens because the shock can spread to other sectors or the wider regions [17]. The bank inflows quickly became outflows. This is in line with Forbes and Rigobon's [14] research that concludes transmission of return volatility and leading to speculative attacks on other countries.

Fratzscher [16] analyzes the role of contagion in the currency crises in emerging markets during the 1990s. The findings suggest that in particular, the degree of financial interdependence and also real integration among emerging markets are crucial not only in explaining past crises but also in predicting the transmission of future financial crises. This paper argues that the main reason for the poor performance of the standard currency crisis model lies in ignoring the role of contagion - the fact that crises can be transmitted across countries through their interdependence with others. The empirical analysis found strong evidence that the 1994-1995 Latin American crisis and the 1997-1998 Asian crisis were contagious, spreading to countries that were not only economically vulnerable but also closely related financially. Moreover, Fratzscher [16] argues that the rapid capital account liberalization and the opening to international markets, which lead to increased real and financial interdependence among emerging markets, played a crucial role in explaining both the timing and the severity of those crises. The result is in line with Claessens and Forbes [18] who discover the occurrence of vulnerability in the country as a result of shocks that occur in other countries.

Kibritcioglu et al. [19] research is to investigate and discuss the predictability of possible currency crises in Turkey by using the leading economic indicators approach. This research concludes that the financial linkages and also investor sentiments and perceptions are the channel of transmission of East Asian crises [19]. The first generation argues that the weak fundamental role is a trigger for the currency crisis. Government budget deficits are at the root of speculative attacks on pegged exchange rates. Therefore, the currency crises are preceded by macroeconomic imbalances that are not consistent with the maintenance of fixed exchange rates. The second generation considers the fundamental aspect of the economy and the behavior of agents as the trigger of the currency crisis. This research also cites a recent study by Paul Krugman [20] and others about the third-generation model of the currency crisis. This new model considers several disputed issues such as (1) moral hazard or asymmetric information problems that lead to an underpricing of risks associated with investment in emerging markets; (2) behavior of herding bankers and portfolio managers; and (3) international contagion effects appearing in several transmission channels such as trade and financial relations between countries.

In addition to review research on contagion, there are also studies that examine the relationship between the exchange rate, interest rate, and stock market. Sensoy and Sobaci [21] analyze the dynamic relationship between the exchange rate (against the US dollar), interest rate, and stock market of Turkey from January 2003 to September 2013. The research reveals that volatility shocks create sudden changes in dynamic correlation, but these effects are only short term. Thus, policymakers and investors do not need to react to volatility shocks to prevent longterm transmission between these markets. The sudden and severe intervention in the money market by central banks in turbulent times can cause considerable losses in foreign currency reserves, which in turn will produce the same results without intervention. On the other hand, investors can maintain their allocation because unexpectedly changing correlations are expected to restore their regular levels in 
the medium and long terms. This research suggests the investors in Turkey have sufficient amounts of foreign currency to minimize the risk of their equity portfolio without reducing expected returns, so investors can hedge risks between the stock market and exchange rates, whether if the stock market is stable or volatile, due to sudden changes in the level of correlation (caused by volatility of shocks) between the stock markets and foreign exchange only happens in the short term.

The research witnesses a consistent negative correlation between the bonds and the stock markets [21]. Besides that, there is a consistent positive correlation between bonds and foreign exchange markets in Turkey, which is different from developed countries. This is an evidence of the negative anticipation of the investors when interest rates increase in emerging markets with a history of high budget deficits. Therefore, an increase in interest rates is perceived as a problem in the country. This event results in a severe capital outflow, thus leading to local currency depreciation against the US dollar. Regarding the stock and foreign exchange market relationship, Sensoy and Sobaci [21] discover a positive relation between dollar appreciation against Turkish lira and Turkish stock market returns.

Clark et al. [22] examine the effect of exchange rate volatility on trade over the past 30 years. The analysis shows that there is no evidence of a large negative effect of exchange rate volatility on trade. This shows that exchange rate volatility is not the major policy problem of trade, but this does not exclude the possibility that a high exchange rate volatility can affect the economy through other channels.

Kawai et al. [23] investigate the origins of the East Asian crisis and its contagion and examine the channels of contagion. The research concludes that the financial linkage and also investor sentiments and perceptions are the the channel of transmission of East Asian crises. They summarize some steps to prevent, manage, and resolve the crises. There are three ways in preventing crises and contagion, namely, (1) avoiding large current account deficits financed through short-term private capital inflows; (2) aggressively regulating and supervising financial systems to ensure that banks and nonbank financial institutions manage risks prudently; and (3) putting in place incentives for sound corporate finance to prevent high leverage ratios and overreliance on foreign borrowing. If the crises already happen, the study provides three solutions in managing crises and contagion, such as the following: (1) in the context of sound policies, mobilize timely external liquidity of sufficient magnitude to restore market confidence; (2) at times of crisis, "bail-in" private foreign creditors; and (3) there is no one-size-fits-all monetary and fiscal stance for responding to crises and contagions. The final structural focus of policymakers is to strengthen crisis resolution mechanisms that will create conditions for the initial resolution of the systemic consequences of a crisis. These mechanisms include (1) establishing domestic and international mechanisms to deal with assets and liabilities of banks and companies that cannot survive and (2) mitigating the impact of the crisis on low-income groups through social policies to correct the inevitable social tensions associated with adjustments.

There is also a study that focuses on discussing the contagion of the crisis in Indonesia. Iriana and Sjöholm [24] examine whether the contagion from the 1997 economic crisis in Thailand triggered the crisis in Indonesia. The result shows that contagion was exacerbated by increasing imbalances in the Indonesian economy. The paper also states that contagion occurs because of two reasons. The first fundamental links are related to the normal interdependence across countries. The second category is related to the behavior of financial markets, such a financial panic, herd behavior, loss of confidence, and increased risk aversion. In the case of Indonesia, this study reveals that investors' behavior rather than real links is identified as one important channel for the contagion to Indonesia (Table 2). 
Contagion, Exchange Rate, and Financial Volatility: Indonesian Case in Global Financial...

DOI: http://dx.doi.org/10.5772/intechopen.92275

\begin{tabular}{|c|c|c|}
\hline No. & Characteristics & Author \\
\hline 1. & $\begin{array}{l}\text { The rises in cross-market linkage aftershocks, measured by } \\
\text { movements together on asset prices and financial flows across } \\
\text { the market }\end{array}$ & $\begin{array}{l}\text { Dornbusch et al. [9]; Forbes and } \\
\text { Rigobon [14]; and Forbes and } \\
\text { Rigobon [11] }\end{array}$ \\
\hline 2. & $\begin{array}{l}\text { The occurrence of vulnerability in the country as a result of } \\
\text { shocks that occur in other countries }\end{array}$ & Claessens and Forbes [18] \\
\hline 3. & $\begin{array}{l}\text { The crisis that spread to other countries that are } \\
\text { geographically separated does not have structural similarities, } \\
\text { and there is no direct linkage }\end{array}$ & Claessens and Forbes [18] \\
\hline 4. & The increasing correlation between countries after the crisis & Dornbusch et al. [9] \\
\hline 5. & The spread of the shock to the sector or the wider region & Allen and Gale [17] \\
\hline 6. & Co-movements in asset prices and quantity across-market & $\begin{array}{l}\text { Pericoli and Sbracia [10]; Forbes } \\
\text { and Rigobon [11] }\end{array}$ \\
\hline 7. & $\begin{array}{l}\text { Transmission of return volatility and leading to speculative } \\
\text { attacks on other countries }\end{array}$ & Forbes and Rigobon [14] \\
\hline 8. & $\begin{array}{l}\text { Transmission of local unanticipated shocks to another country } \\
\text { or another financial market }\end{array}$ & Masson $[12,13]$ \\
\hline 9. & $\begin{array}{l}\text { An episode where there are significant effects that evolve over } \\
\text { a matter of hours or days in a number of countries after an } \\
\text { event }\end{array}$ & Kaminsky et al. [15] \\
\hline 10. & $\begin{array}{l}\text { The research concludes that there are two generations of the } \\
\text { theoretical models on currency crises }\end{array}$ & Kibritcioglu et al. [19] \\
\hline 11. & $\begin{array}{l}\text { The research summarizes three transmissions of a crisis, such } \\
\text { as (1) moral hazard or asymmetric information; ( } 2 \text { ) behavior } \\
\text { of herding bankers and portfolio managers; and ( } 3 \text { ) trade and } \\
\text { financial relations between countries }\end{array}$ & Paul Krugman [20] \\
\hline 12. & $\begin{array}{l}\text { The transmission of a crisis to a particular country because of } \\
\text { mutual financial and real interdependence with countries that } \\
\text { have experienced a crisis }\end{array}$ & Fratzscher [16] \\
\hline 13. & $\begin{array}{l}\text { The financial linkage and also investor sentiments and } \\
\text { perceptions are the transmission of the East Asian crises }\end{array}$ & Kawai et al. [23] \\
\hline 14. & $\begin{array}{l}\text { There is no strong evidence of the large negative effects of } \\
\text { exchange rate volatility on trade }\end{array}$ & Clark et al. [22] \\
\hline 15. & $\begin{array}{l}\text { Contagion occurs because there are fundamental links across } \\
\text { countries and the behavior of financial markets }\end{array}$ & Iriana and Sjöholm [24] \\
\hline \multicolumn{3}{|c|}{ Source: Authors, 2019.} \\
\hline
\end{tabular}

Table 2.

Literature review of contagion theory.

\section{Research method}

\subsection{VAR and OLS method}

The research uses VAR and dynamic conditional correlation (DCC) methods to assess the three important financial and external variables including contagion, exchange rate, and financial volatility of Indonesia triggered by global turbulence and Argentina-Turkey crisis in 2018. Data used in this research are the monthly data from 2004 to 2018. The VAR method has also been conducted by Marcel Fratzscher [16] to examine the impact of exchange rate crisis and its transmission (Table 3).

The VAR model can be expressed in Eq. (1): 


$$
Y_{t}=\alpha_{1 i}+\sum \beta_{1 i} Y_{t-n}+\sum \gamma_{1 i} X_{t-n}+\epsilon_{1 t}
$$

where $\mathrm{Y}_{\mathrm{t}}$ is the rupiah exchange rate against US Dollar in year $t ; \mathrm{Y}_{\mathrm{t}-\mathrm{n}}$ is the rupiah exchange rate against the US dollar in year $\mathrm{t}-\mathrm{n}$; $\mathrm{X}_{\mathrm{t}-\mathrm{n}}$ is the economic condition of Indonesia in year $\mathrm{t}-\mathrm{n}$; $\alpha$ is the constants; and $\epsilon$ is the error.

The model can be estimated using the ordinary least squares (OLS) method separately. The OLS method is widely used to estimate the linear regression parameter model. The OLS model used according to Gujarati [25] is as follows:

$$
Y=\beta_{0}+\sum_{t}=1 \ldots p \beta_{t} X_{t}+\varepsilon
$$

where $Y$ is the dependent variable, $\beta_{0}$ is the intercept of the model, $X_{t}$ corresponds to the texplanatory variable of the model $(j=1$ to $p)$, and e is the random

\begin{tabular}{|c|c|c|c|}
\hline No. & Variables & Descriptions & Data sources \\
\hline 1. & Stock price & $\begin{array}{l}\text { Stock price in ISTANBUL MERVAL, Jakarta, } \\
\text { NASDAQ }\end{array}$ & Bloomberg database \\
\hline 2. & FDI & Foreign direct investment & CEIC database \\
\hline 3. & LER_LIRA & Lira exchange rate to US dollar & Bloomberg database \\
\hline 4. & NFP & Net foreign purchase & Bloomberg database \\
\hline 5. & LER & Indonesia rupiah exchange rate to US dollar & Bloomberg database \\
\hline 6. & ARS & Argentina peso exchange rate to US dollar & Bloomberg database \\
\hline 7. & PUAB & Interbank rates & $\begin{array}{l}\text { External sector statistics, } \\
\text { Bank Indonesia }\end{array}$ \\
\hline 8. & NET_EXPORT & Net exports & $\begin{array}{l}\text { Indonesia Central Bureau } \\
\text { of Statistics }\end{array}$ \\
\hline 9. & LIP_INA & Production index & $\begin{array}{l}\text { Indonesia Central Bureau } \\
\text { of Statistics, Central Bank } \\
\text { of Indonesia }\end{array}$ \\
\hline 10. & TB & Balance of trade & $\begin{array}{l}\text { External sector statistics, } \\
\text { Central Bank of Indonesia }\end{array}$ \\
\hline 11. & FINANCIAL & $\begin{array}{l}\text { Financial accounts. The domestic ownership } \\
\text { of foreign assets and the foreign ownership of } \\
\text { domestic assets }\end{array}$ & $\begin{array}{l}\text { External sector statistics, } \\
\text { Central Bank of Indonesia }\end{array}$ \\
\hline 12. & PRIMARY_INCOME & $\begin{array}{l}\text { The net flow of profits, interests, and } \\
\text { dividends from investments in other } \\
\text { countries and net remittance flows from } \\
\text { migrant workers }\end{array}$ & $\begin{array}{l}\text { External sector statistics, } \\
\text { Central Bank of Indonesia }\end{array}$ \\
\hline 13. & M2 & Broad money & $\begin{array}{l}\text { Monetary sector statistics, } \\
\text { Central Bank of Indonesia }\end{array}$ \\
\hline 14. & COMPRICE & Commodity price index & $\begin{array}{l}\text { International Monetary } \\
\text { Fund }\end{array}$ \\
\hline 15. & DUMMY & Dummy tapering off & $\begin{array}{l}1=\text { after tapering off } 2013 \\
0=\text { before tapering off }\end{array}$ \\
\hline 16. & $\mathrm{AR}$ & Autoregressive & \\
\hline
\end{tabular}
error with expectation 0 and variance $\sigma^{2}$.

Source: Authors, 2019.

Table 3.

Data operational and sources. 


\subsection{DCC method}

The DCC representation was introduced by Engle [26] to capture the empirically observed dynamic contemporaneous correlations of asset returns. This is the latest method that allows simultaneous variant modeling and conditional correlation from several series. The estimation consists of two steps. First, we estimate the conditional variance of each variable using the univariate autoregressive conditional heteroscedasticity $(\mathrm{ARCH})$ procedure. Second, we use the standard regression residues obtained in the first step to model conditional correlations that vary over time.

The essence of this model is the covariance matrix $\left(H_{t}\right)$, which is compiled into a diagonal matrix from standard conditional deviation $\left(D_{t}\right)$ and matrix correlation containing the conditional correlations $\left(R_{t}\right)$. In the DCC GARCH model, both the $D_{t}$ and $R_{t}$ models are designed to be time-varying. The DCC GARCH model is defined as:

$$
H_{t}=D_{t} R_{t} D_{t}
$$

where $D_{t}$ is a diagonal matrix $\mathrm{k} x \mathrm{k}$ of a standard deviation which has a different time of univariate GARCH with $\sqrt{h_{i, t}}$ on the diagonal $i^{t h}$ and $R_{t}$ is the time variation of the correlation matrix.

$$
D_{t}=\left[\begin{array}{cccc}
\sqrt{h_{i, t}} & 0 & \cdots & 0 \\
0 & \sqrt{h_{i, t}} & \ddots & \vdots \\
\vdots & \ddots & \ddots & 0 \\
0 & \cdots & 0 & \sqrt{h_{i, t}}
\end{array}\right]
$$

where

$$
\begin{aligned}
h_{i, t}=\omega_{i}+ & \sum_{p=1}^{P_{1}} \alpha_{i p} r_{i t-p}^{2}+\sum_{q=1}^{Q 1} \beta_{i q} h_{i t-q} \text { fori }=1,2,3, \ldots, \mathrm{k} \\
R_{t}= & {\left[\begin{array}{ccccc}
1 & P_{12, t} & P_{13, t} & \ldots & P_{1 n, t} \\
P_{12, t} & 1 & P_{13, t} & \cdots & P_{2 n, t} \\
P_{13, t} & P_{23, t} & 1 & \ddots & \vdots \\
\vdots & \vdots & \ddots & \ddots & P_{n-1, n, t} \\
P_{1 n, t} & P_{2 n, t} & \ldots & P_{n-1, n, t} & 1
\end{array}\right] }
\end{aligned}
$$

Two requirements must be considered when specifying the form of $R_{t}$ :

1. $H_{t}$ must be positively defined because it is in the form of a covariance matrix. To ensure positive definite $H_{t}, R_{t}$ must be positive too.

2. All elements in the correlation matrix $R_{t}$ must be equal to or less than one.

Therefore, $R_{t}$ is structured as follows:

$$
\begin{gathered}
R_{t}=Q_{t}^{*-1} Q_{t} Q_{t}^{*-1} \\
Q_{t}=(1-a-b) \bar{Q}+\propto \varepsilon_{t-1} \varepsilon_{t-1}^{T}+b Q_{t-18}
\end{gathered}
$$


where parameters a and $\mathrm{b}$ are scalars, $\bar{Q}$ is an unconditional covariance of standardized residues produced from univariate GARCH equations, and $Q_{t}^{*}$ is a diagonal matrix consisting of square roots of diagonal elements $Q_{t}$ :

$$
Q_{t}^{*}=\left[\begin{array}{cccc}
\sqrt{q_{i, t}} & 0 & \cdots & 0 \\
0 & \sqrt{q_{i, t}} & \ddots & \vdots \\
\vdots & \ddots & \ddots & 0 \\
0 & \cdots & 0 & \sqrt{q_{i, t}}
\end{array}\right]
$$

The typical element $R_{t}$ is $\rho_{i j t}=\frac{q_{i t}}{\sqrt{q_{i i} q_{j j}}}$, and the matrix $R_{t}$ will be a positive/constant. The Kasset covariance matrix $H_{t}$ is thus definite/constant and can be written as $H_{t}=D_{t} R_{t} D_{t}$.

\subsection{Net correlation after controlling fundamental}

\subsubsection{Net correlation for stock market}

Normally, stock market correlation already represents the interdependence of stock market between countries. However, it might be overestimated due to fundamentals. Therefore, we perform an estimation to obtain a fundamental factorfree stock return for country $i$ in period $t\left(\varepsilon_{i, t}\right)$. The estimation is in Eqs. (10)-(12):

$$
\begin{aligned}
& \text { Stock }_{\text {indo }, t}=\alpha+\beta_{1} \text { Balance }_{\text {indo }, t}+\beta_{2} \text { Int }_{\text {indo }, t}+\beta_{3} \text { Inf }_{\text {indo }, t}+\beta_{4} \text { World }_{t}+\varepsilon_{\text {indo }, t} \\
& \text { Stock }_{\text {arg }, t}=\alpha+\beta_{1} \text { Balance }_{\text {arg }, t}+\beta_{2} \text { Int }_{\text {arg }, t}+\beta_{3} \operatorname{Inf}_{\text {arg }, t}+\beta_{4} \text { World }_{t}+\varepsilon_{\text {arg }, t t} \\
& \text { Stock }_{\text {tur }, t}=\alpha+\beta_{1} \text { Balance }_{\text {tur }, t}+\beta_{2} \text { Int }_{\text {tur }, t}+\beta_{3} \text { Inf }_{\text {tur }, t}+\beta_{4} \text { World }_{t}+\varepsilon_{t u r, t}
\end{aligned}
$$

Note:

Stock: stock market returns country $i$ period $t$.

Balance: trade balance country $i$ period $t$.

Int: interest rate country $i$ period $t$.

Inf: inflation rate country $i$ period $t$.

World: world stock market period $t$.

To perform the estimation, we use several variables retrieved from various sources. We obtain the stock market index data for each country from Yahoo Finance. The data are available in monthly; hence, we calculate month-on-month (m-o-m) stock return from the data and then calculate the quarterly average from the obtained $\mathrm{m}-\mathrm{o}-\mathrm{m}$ return. We calculate the trade balance by subtracting the export value from the import value within period $t$ in the US dollar denomination. These data are obtained from the International Financial Statistics (IFS). For interest rate, ideally, we use policy rates for each country. However, the data is not available for Turkey and incomplete for Indonesia because Indonesia changed its policy rate from BI rate to BI7DRR (7-day reverse repo rate) in 2016 and thus not comparable with the interest rate in the period earlier than 2016.

We obtain a year-on-year (y-o-y) quarterly inflation rate, which is publicly available from the Organization for Economic Co-operation and Development (OECD) database. Unfortunately, Argentina does not report monthly inflation rate before 2018. The annual inflation rate for Argentina is also not reported. As a result, we decided to interpolate the annual GDP deflator into quarterly deflator to 
substitute inflation rate. We also clean up the stock return from the international market sentiment. Hence, following Fratzscher [16], we use trading volumeweighted average of S\&P 500, FTSE 100, and Nikkei return as explanatory.

\subsubsection{Net correlation for exchange rate}

Normally, the exchange rate correlation already represents the interdependence of stock market between countries. However, it might be overestimated due to fundamentals. Therefore, we perform an estimation to obtain fundamental factorfree exchange rate for country $i$ in period $t\left(\varepsilon_{i, t}\right)$. To ensure stationarity, we run the regression in first-difference form as in Eqs. (13)-(15):

$$
\begin{aligned}
d\left(\text { Exrate }_{i d n, t}\right)= & \alpha+\beta_{1} d\left(m_{i d n, t}-m_{u s, t}\right)+\beta_{2} d\left(\inf _{i d n, t}-i n f_{u s, t}\right)+\beta_{3} d\left(r_{i d n, t}-r_{u s, t}\right) \\
& +\beta_{4} d\left(y_{i d n, t}-y_{u s, t}\right)+\varepsilon_{i d n, t}
\end{aligned}
$$

$$
\begin{aligned}
d\left(\text { Exrate }_{\text {tur }, t}\right)= & \alpha+\beta_{1} d\left(m_{t u r, t}-m_{u s, t}\right)+\beta_{2} d\left(i n f_{t u r, t}-i n f_{u s, t}\right)+\beta_{3} d\left(r_{t u r, t}-r_{u s, t}\right) \\
& +\beta_{4} d\left(y_{t u r, t}-y_{u s, t}\right)+\varepsilon_{t u r, t}
\end{aligned}
$$

$$
\begin{aligned}
d\left(\text { Exrate }_{\text {arg }, t}\right)= & \alpha+\beta_{1} d\left(m_{\text {arg }, t}-m_{u s, t}\right)+\beta_{2} d\left(\text { inf }_{\text {arg }, t}-\text { inf }_{u s, t}\right)+\beta_{3} d\left(r_{\text {arg }, t}-r_{u s, t}\right) \\
& +\beta_{4} d\left(y_{\text {arg }, t}-y_{u s, t}\right)+\varepsilon_{\text {arg }, t}
\end{aligned}
$$

Note:

Exrate: exchange rate in USD country $i$ period $t$.

$m$ : money supply growth country $i$ period $t$.

inf : inflation rate country $i$ period $t$.

$r$ : interest rate country $i$ period $t$.

$y$ : real GDP market period $t$.

Variables within the model are coming from various sources. Our dependent variable is coming from the IFS. As in Engel (2002), we use the end-of-quarter nominal exchange rate. Other explanatories including money supply, consumer price index (CPI), and real GDP are obtained from the OECD database. As we compared the variables for each country with those of the United States, we have to ensure that the variables are in the same unit. Hence, money supply, consumer price index, and real GDP are used in growth. For money supply and GDP, we use quarterly growth. However, for CPI growth, we have to use the annual inflation rate instead of quarterly inflation rate for Indonesia, Turkey, and the United States, since we have to use interpolated annual GDP deflator as a proxy for change in price level for Argentina due to the unavailability of quarterly CPI data for Argentina.

For interest rate, ideally, we use policy rates for each country. While we use policy rate for Argentina and the United States, policy rate data is not available for Turkey and incomplete for Indonesia since Indonesia changed its policy rate from $\mathrm{BI}$ rate to BI7DRR (7-day reverse repo rate) in 2016; hence, we use money market rate for both countries. 


\section{Result and analysis}

\subsection{Indonesia trade link with Argentina and Turkey}

The following figures summarize the share of Indonesian export and import to and from Turkey and Argentina, as well as with the United States as a benchmark.

The United States is one of the Indonesia's main trade partners, besides China. Indonesia's export share to the United States has a declining trend. Even so, the value is higher than the value of the US product imports into Indonesia. In 2018, the value of Indonesia's exports to the United States was USD 18,439,760.7 thousand, while the value of imports from the United States to Indonesia reached USD $10,176,226.6$ thousand.

Indonesian exports to Argentina and Turkey tend to be stable. Figure 2 shows that in the last 3 years, imports from Argentina were higher than imports from Turkey and the Philippines. Even the value of Argentine imports to Indonesia is higher than Indonesian exports to Argentina. The Indonesian Ministry of Trade data from 2014 to June 2019 shows that the trade balance resulting from Indonesia's trade activities was negative throughout the period (Figure 3).

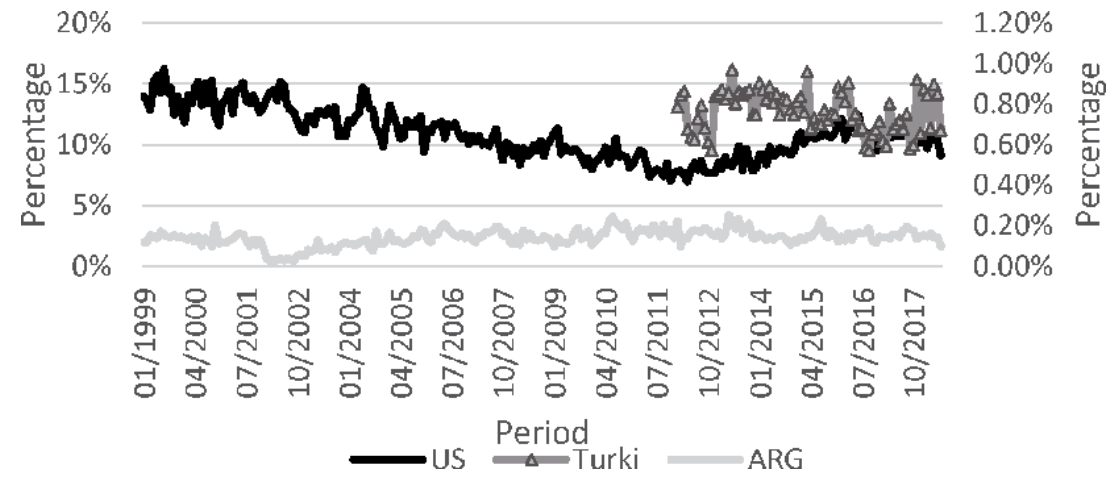

Figure 2.

Share of Indonesia export to several countries. Source: CEIC database.

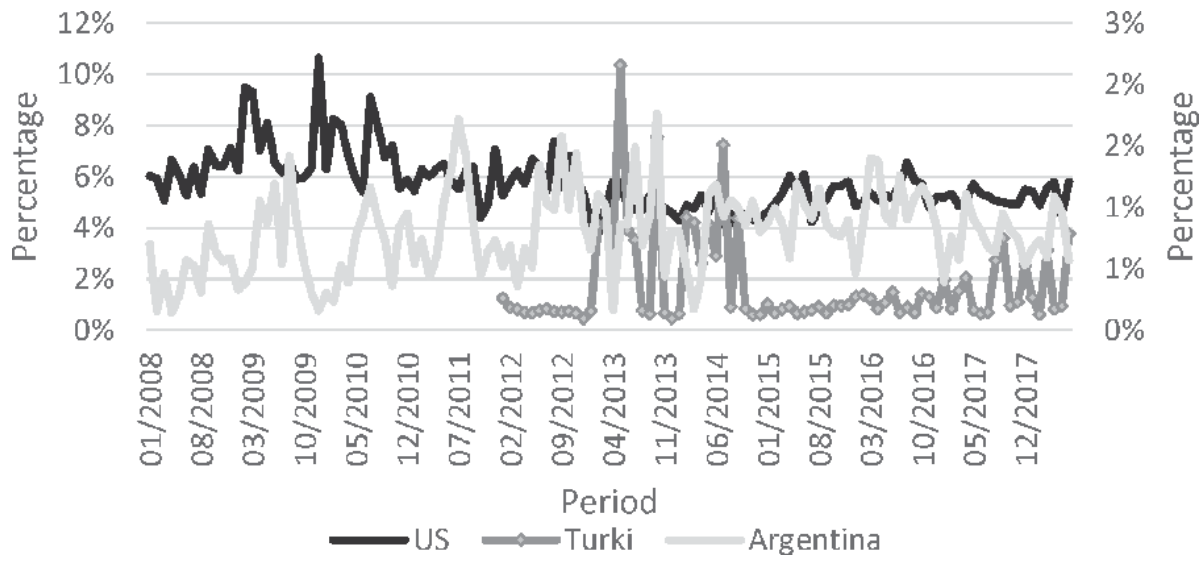

Figure 3 .

Share of Indonesia import from several countries. Source: CEIC database. 


\subsection{Indonesia FDI link with Argentina and Turkey}

Based on Figure 4, the share of FDI from Turkey to Indonesia is from 0 to $0.749 \%$. The range is higher than from Argentina, which is only $0-0.001 \%$. The FDI trend from the United States is declining, while those from China are increasing. It is also necessary to be aware of the decline in FDI flows from countries affected by the Turkey and Argentina crises (direct and indirect). Besides that, exploring the FDI flows between China and Turkey, China and Argentina, the United States and Turkey, the United States and Argentina, Europe and Turkey, and Europe and Argentina is also important.

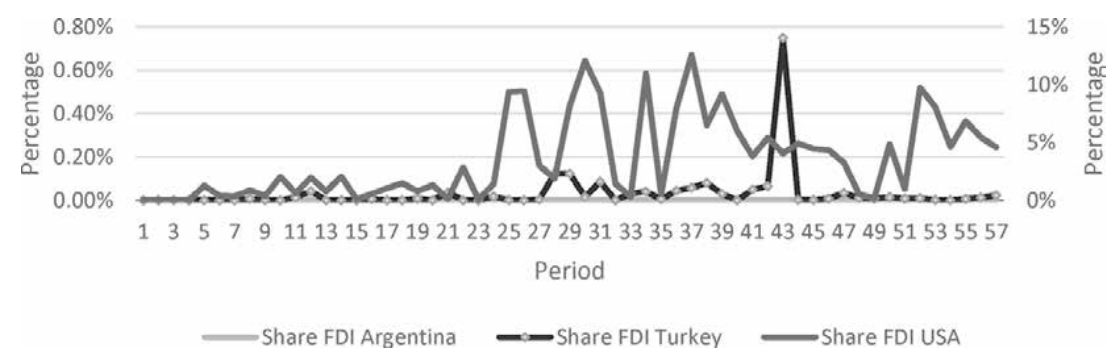

Figure 4 .

Share of foreign direct investment to Indonesia. Source: CEIC database.

\subsection{Indonesia financial link with Argentina and Turkey}

\subsubsection{Measuring contagion with correlation}

The figure above shows that Jakarta composite index (JCI) has the highest correlation with MERVAL, namely, the Argentina exchange (0.9), and the second highest is with ISTANBUL (0.89) or Turkish stock exchange. Thus, the government of Indonesia has to pay attention to the high correlation potential with both countries. Correlation with NASDAQ (US exchange) is significant but slightly below Turkey (0.88). NASDAQ has a high and significant correlation with the three emerging market stock exchanges (Turkey, Indonesia, and Argentina) (Figure 5 and Table 4).

Table 5 shows the adjusted correlation coefficients before and during the crisis. All of the coefficients increase during the crisis, except the contagion between Indonesia and Malaysia which the stock price fell sharply. Meanwhile, the correlation between the Thai and Indonesian exchange rates and between the Thai and Malaysian exchange rates experiences a high surge during the crisis.

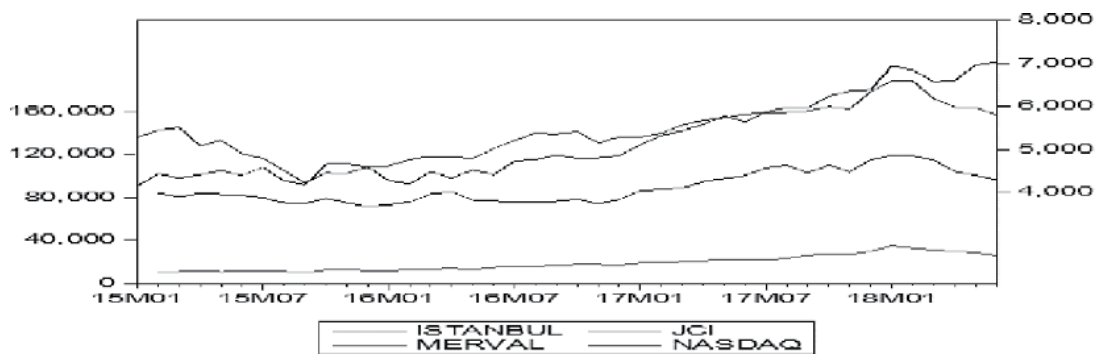

Figure 5.

Stock price index graph (United States, Turkey, Argentina, Indonesia). Source: Authors, 2019. 


\begin{tabular}{lccccc}
\hline Correlation & NASDAQ & MERVAL & JCI & ISTANBUL & BROAD_USD \\
\hline NASDAQ & 1.000 & & & \\
\hline MERVAL & - & & & \\
\hline & 0.964 & 1.000 & & \\
\hline JCI & 22.783 & - & & \\
\hline & 0.878 & 0.901 & 1.000 & 1.000 & \\
\hline ISTANBUL & 11.436 & 12.995 & - & - & 1.000 \\
\hline & 0.896 & 0.905 & 0.891 & -0.208 & - \\
\hline BROAD_USD & 12.578 & 13.295 & 12.280 & -1.330 & \\
\hline
\end{tabular}

Source: Authors Calculation, 2019.

Table 4.

Correlation result.

\begin{tabular}{lcccccc}
\hline Period & \multicolumn{3}{c}{ Stock market } & \multicolumn{3}{c}{ Exchange rate } \\
\cline { 2 - 7 } & $\begin{array}{l}\text { Thailand- } \\
\text { Indonesia }\end{array}$ & $\begin{array}{l}\text { Malaysia- } \\
\text { Indonesia }\end{array}$ & $\begin{array}{l}\text { Thailand- } \\
\text { Malaysia }\end{array}$ & $\begin{array}{l}\text { Thailand- } \\
\text { Indonesia }\end{array}$ & $\begin{array}{l}\text { Malaysia- } \\
\text { Indonesia }\end{array}$ & $\begin{array}{l}\text { Thailand- } \\
\text { Malaysia }\end{array}$ \\
\hline Tranquil & 0.25 & 0.26 & 0.08 & 0.02 & 0.12 & 0.14 \\
\hline Crisis & 0.29 & 0.07 & 0.09 & 0.19 & 0.14 & 0.31 \\
\hline $\begin{array}{l}\text { Statistically } \\
\text { significant }\end{array}$ & -0.54 & $2.55^{* *}$ & -0.14 & $-2.26^{* *}$ & -0.037 & $-2.29^{* *}$ \\
$\begin{array}{l}\text { ** Significant at a 5\% level. } \\
\text { Source: Iriana and Sjöholm [24]. }\end{array}$ & & & & & & \\
\hline
\end{tabular}

Table 5.

Contagion in the currency and stock markets (adjusted correlation coefficients) in 1997 from Iriana and Sjöholm [24].

A negative and statistically significant coefficient means that there is evidence of contagion. The increases in the correlation between the Thai and Indonesian exchange rate and between the Thai and Malaysian exchange rate are statistically significant. Therefore, the results show that difficulties in Thailand are transmitted to the Indonesian and Malaysian currency markets. There are no signs of contagion on the stock market because an increase in the correlation coefficient is not

\begin{tabular}{cccccc}
\hline & Stock market & & \multicolumn{3}{c}{ Exchange rate } \\
\hline Year & JCI-MERVAL & JCI-Turkey & Year & IDR-ARS & IDR-TRY \\
\hline 2015 & -0.338 & 0.779 & 2015 & 0.341 & 0.930 \\
\hline 2016 & 0.924 & -0.154 & 2016 & -0.252 & 0.279 \\
\hline 2017 & 0.917 & 0.932 & 2017 & 0.713 & 0.725 \\
\hline 2018 & 0.952 & 0.950 & 2018 & 0.841 & 0.826 \\
\hline
\end{tabular}

Source: Authors Calculation, 2019.

Table 6.

Potential contagion: correlation rises during crisis. 


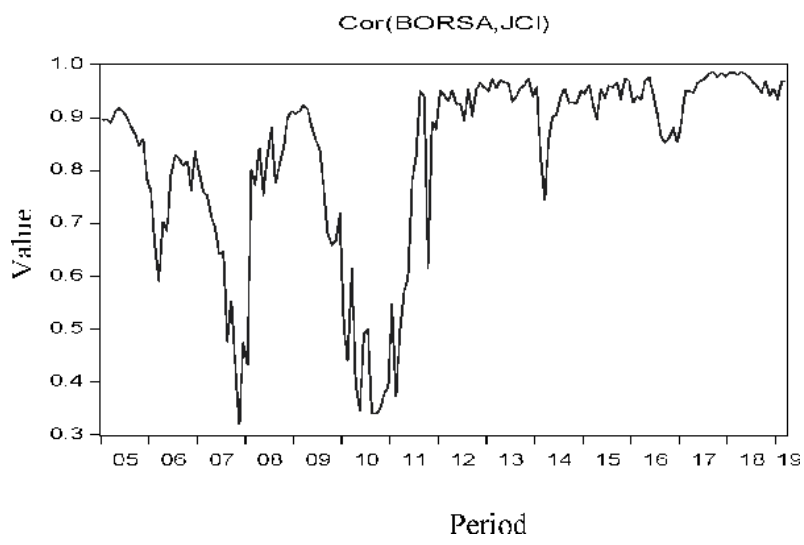

Figure 6.

BORSA (Turkey)_JCI (Indonesia) correlation 2005-2019. Source: Authors, 2019.

statistically significant. In fact, there is a statistically significant decrease in the correlation coefficient between the Malaysian and Indonesian stock markets. One plausible explanation for this decline is the adoption of Malaysian capital controls in late August and early September 1998 [24].

Table 6 shows the correlation coefficients of the stock market and exchange rate in some years. Changes in the correlation between the stock market and the exchange rate of Indonesia from 2017 to 2018 were not as big as when the economic crisis of 1997. This happens because after the crises, Indonesia becomes more vigilant so that various agencies were formed to predict and overcome crises. There is an increase in the correlation between Indonesian stock prices from 2017 to 2018 both with Argentina and Turkey's stock prices. Something similar also happens to the exchange rate. There is an increase in the correlation between the Indonesian exchange rate from 2017 to 2018 both with the exchange rates of Argentina and Turkey (Table 6).

\section{Conditional Correlation}

Cor(JCI,MERVAL)

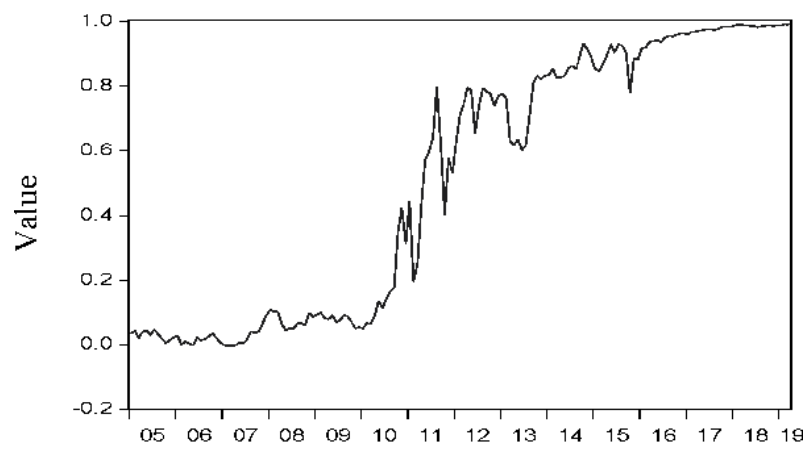

Period

Figure 7.

MERVAL (Argentina)—JCI (Indonesia) correlation 2005-2019. Source: Authors, 2019. 


\subsubsection{Dynamic conditional correlation}

\subsection{Stock market}

Throughout 2005-2019, the correlation between the Turkish stock market and Indonesian stock market is in the range of 0.6-0.9. The biggest decline occurs in 2007 and 2010 which reach 0.3, and the highest correlation increase occurs in 2018 (Figure 6). Meanwhile, Figure 7 shows a correlation between Argentine stock market and Indonesian stock market which experience an upward trend since 2011. The upward trend between Argentina's stock market and Indonesia's stock market also happened since 2013, as well as in the periods of 2016-2018.

\subsection{Exchange rate}

The exchange rate correlations between 2005 and 2019 experience fluctuations. The correlation between lira and rupiah begins with a negative value, which is almost touching -0.5. In addition to 2005, in 2008 and 2014 lira and rupiah are also

\section{Conditional Correlation}

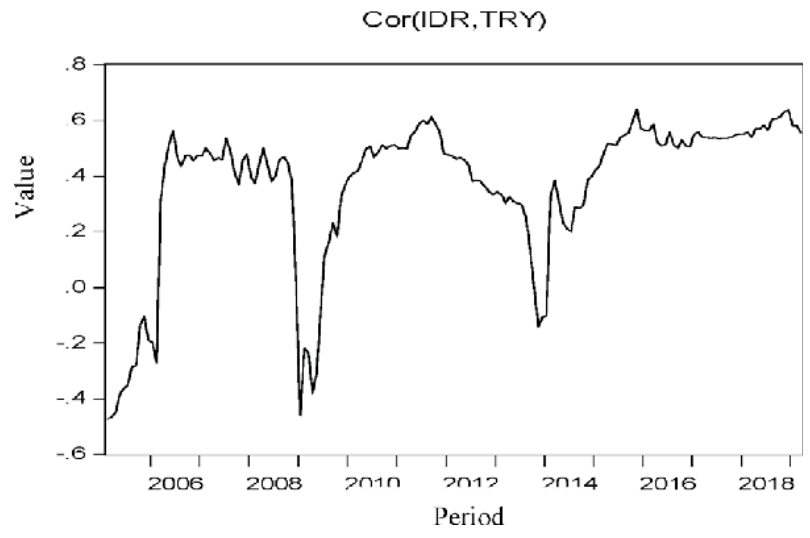

Figure 8.

Turkey lira-Indonesia rupiah correlation 2005-2019. Source: Authors, 2019.

\section{Conditional Correlation}

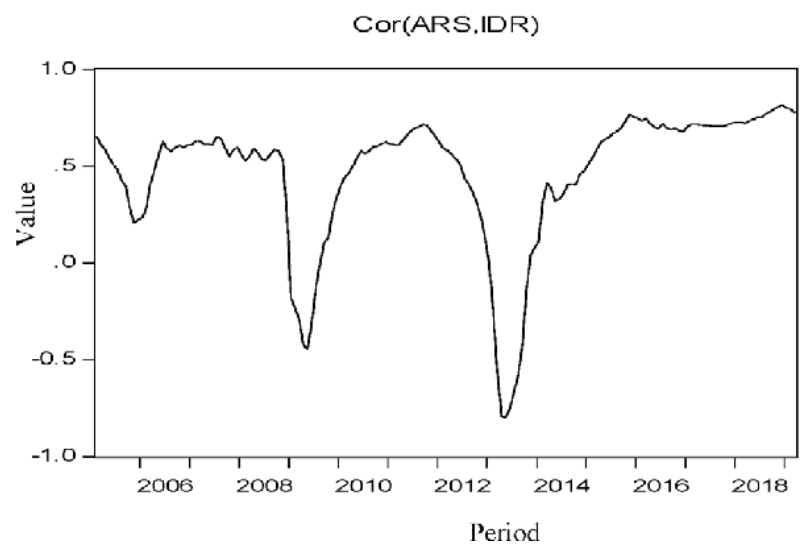

Figure 9.

Peso Argentina-Indonesia rupiah correlation 2005-2019. Source: Authors, 2019. 
Contagion, Exchange Rate, and Financial Volatility: Indonesian Case in Global Financial... DOI: http://dx.doi.org/10.5772/intechopen.92275

\begin{tabular}{|c|c|c|c|}
\hline Correlation & Argentina & Indonesia & Turkey \\
\hline \multicolumn{4}{|c|}{ 2002Q3-2008Q4 } \\
\hline Argentina & 1.000 & 0.036 & 0.125 \\
\hline Indonesia & 0.036 & 1.000 & 0.046 \\
\hline Turkey & 0.125 & 0.046 & 1.000 \\
\hline \multicolumn{4}{|c|}{ 2009Q1 - 2018Q4 } \\
\hline Argentina & 1.000 & 0.207 & 0.088 \\
\hline Indonesia & 0.207 & 1.000 & 0.423 \\
\hline Turkey & 0.088 & 0.423 & 1.000 \\
\hline
\end{tabular}

Source: Author Calculation, 2019.

Table 7.

Net correlation in stock market after extracting fundamental.

negatively correlated. Meanwhile, the correlation between peso and rupiah experiences a negative correlation from the end of 2008 to the beginning of 2009 and at the beginning of 2013 (Figures 8 and 9).

Table 7 shows the net correlation after controlling fundamental between Argentina, Indonesia, and Turkey in terms of capital markets. The results show that the highest correlation was between Indonesia and Turkey from 2009 to 2018. Meanwhile, the lowest correlation was between Indonesia and Argentina in 2002 quarter 3 to the end of 2008 .

\subsubsection{VAR results}

By using monthly data and the lira exchange rate as the endogenous variables, the research will analyze the impact of weaker lira on the Indonesian economy (VAR dynamic method). Table 8 shows that the change in lira exchange rate is dominant in explaining changes in the rupiah exchange rate (26-37\%).

\begin{tabular}{cccccccc}
\hline Period & SE & Lira & $\begin{array}{c}\text { Net foreign } \\
\text { purchase }\end{array}$ & Rupiah & $\begin{array}{c}\text { Interbank } \\
\text { rates }\end{array}$ & $\begin{array}{c}\text { Net } \\
\text { export }\end{array}$ & $\begin{array}{c}\text { LIP (production } \\
\text { index) }\end{array}$ \\
\hline 1 & 0.031 & 26.635 & 0.096 & 73.269 & 0.000 & 0.000 & 0.000 \\
\hline 2 & 0.033 & 35.264 & 0.080 & 63.237 & 0.177 & 0.852 & 0.390 \\
\hline 3 & 0.033 & 35.947 & 0.216 & 62.291 & 0.174 & 0.895 & 0.476 \\
\hline 4 & 0.034 & 37.063 & 0.224 & 61.157 & 0.174 & 0.881 & 0.500 \\
\hline 5 & 0.034 & 37.077 & 0.263 & 61.073 & 0.174 & 0.909 & 0.504 \\
\hline 6 & 0.034 & 37.088 & 0.264 & 61.058 & 0.175 & 0.910 & 0.506 \\
\hline 7 & 0.034 & 37.092 & 0.266 & 61.049 & 0.175 & 0.913 & 0.505 \\
\hline 8 & 0.034 & 37.092 & 0.266 & 61.048 & 0.175 & 0.914 & 0.506 \\
\hline 9 & 0.034 & 37.092 & 0.266 & 61.048 & 0.175 & 0.914 & 0.506 \\
\hline 10 & 0.034 & 37.092 & 0.266 & 61.048 & 0.175 & 0.914 & 0.506 \\
\hline
\end{tabular}

Source: Authors, 2019.

Table 8.

Variance decomposition of rupiah exchange rate (level). 
Accu mulated Response to Cholesky One S.D. Innovations \pm 2 S.E.

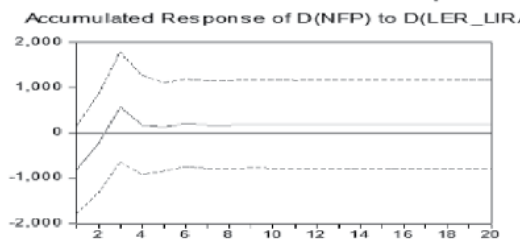

Accumulated Response of D(LER) to D(LER_LIRA)

Accumulated Response of D(PUAB) to D(LER_LIRA)
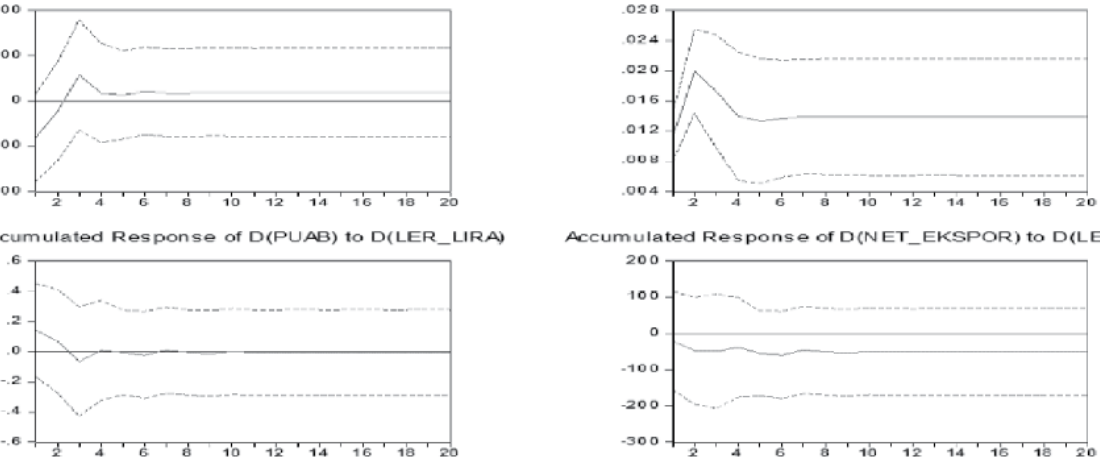

Accumulated Response of D(NET_EKSPOR) to D(LER_LIRA)

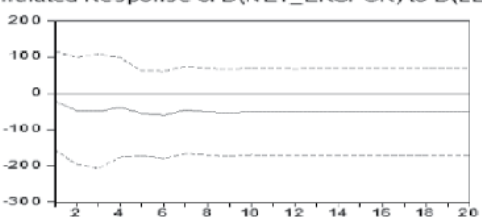

Accumulated Response of D(LIP_INA) to D(LER_LIRA)

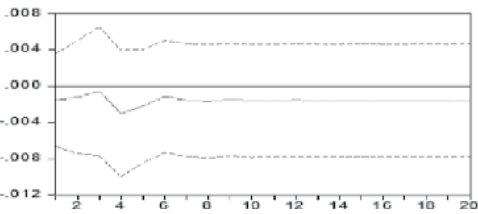

Figure 10.

IRF graph. Source: Authors, 2019.

\begin{tabular}{cccccccc}
\hline Period & SE & $\begin{array}{c}\text { D } \\
\text { (LER_LIRA) }\end{array}$ & $\begin{array}{c}\text { D } \\
(\text { NFP })\end{array}$ & $\begin{array}{c}\text { D } \\
(\text { LER })\end{array}$ & $\begin{array}{c}\text { D } \\
\text { (PUAB) }\end{array}$ & $\begin{array}{c}\text { D } \\
\text { (NET_EXPORT) }\end{array}$ & $\begin{array}{c}\text { D } \\
\text { (LIP_INA) }\end{array}$ \\
\hline 1 & 6080.729 & 0.222 & 1.287 & 0.152 & 1.396 & 3.926 & 93.015 \\
\hline 2 & 6982.743 & 0.202 & 1.954 & 0.349 & 1.376 & 4.916 & 91.202 \\
\hline 3 & 7130.040 & 0.223 & 1.866 & 4.273 & 3.866 & 4.797 & 84.973 \\
\hline 4 & 7163.440 & 0.672 & 1.781 & 4.370 & 6.371 & 5.101 & 81.703 \\
\hline 5 & 7169.733 & 0.721 & 1.772 & 4.351 & 6.560 & 5.234 & 81.363 \\
\hline 6 & 7173.949 & 0.802 & 1.775 & 4.366 & 6.739 & 5.223 & 81.095 \\
\hline 7 & 7176.103 & 0.811 & 1.779 & 4.367 & 7.014 & 5.250 & 80.778 \\
\hline 8 & 7176.375 & 0.812 & 1.780 & 4.366 & 7.051 & 5.260 & 80.731 \\
\hline 10 & 7176.617 & 0.814 & 1.780 & 4.366 & 7.060 & 5.260 & 80.719 \\
\hline
\end{tabular}

Source: Authors Calculation, 2019.

Table 9.

Variance decomposition of Indonesia's industrial production index.

The changes in the Indonesia production index in response to changes in the lira exchange rate variable are relatively small. Interbank rates, net exports, and rupiah exchange rates (apart from the production index itself) get the highest change. So we can conclude that the contagion for Turkey has hit Indonesia more on the financial market, especially exchange rate, and has a small effect on real sector activity represented by industrial production index (Figure 10 and Table 9).

The weakening lira is proven to be the reason why the rupiah moves downward, but the shock would disappear after 5 months (the rupiah value returned to balance). Not only rupiah but also weaker lira also has an impact on the interbank rates 


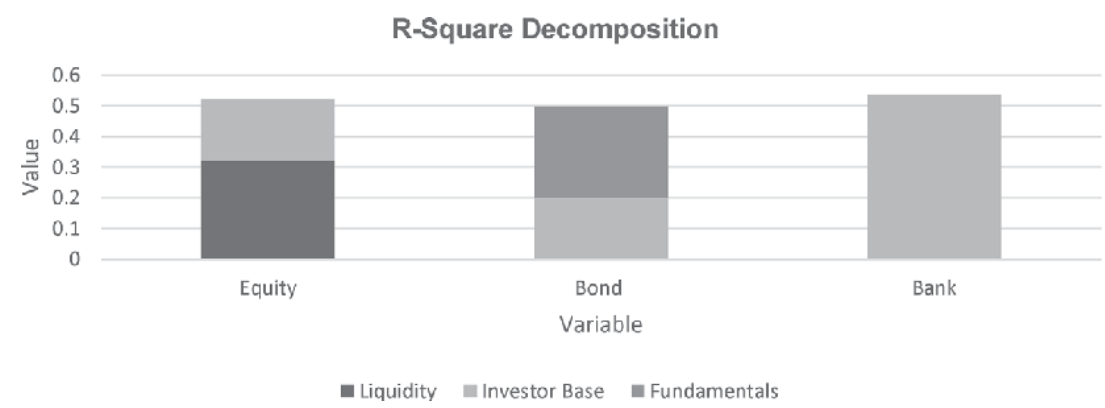

Figure 11.

$R$-square decomposition based on Shepley decomposition. Source: [27].

and NFP. The decline of the lira may increase in the interbank rates, but there is a decline in NFP at the start, even though the NFP could recover after the third month. The weakening of lira also caused a decline in net exports and a manufacturing production index even though with little impact (Figure 10).

Claessens [27] explains that the main reasons of fragility are liquidity and investor based, while macrofundamentals only have a little explaining power except for bond (Figure 11). According to Table 10, Indonesia, Turkey, and Argentina are sensitive to get the impact of capital flow.

\subsection{Rupiah exchange rate model results}

Indonesian capital and financial account in the fourth quarter of 2018 showed a good performance and even had obtained the highest value since 2012. Unfortunately, this is not supported by the current account condition. The current account in the fourth quarter of 2018 continued to deteriorate compared to the previous periods. This occurs because of the global economic slowdown that is currently happening so that Indonesia's exports to several countries have decreased (Figure 12).

\subsection{Exchange rate model result}

$$
\begin{aligned}
\text { EXCH_RATE } E_{t}= & \alpha_{10}+\beta_{11} \text { TB }_{t-1}+\beta_{12} \text { FINANCIAL }_{t-1}+\beta_{13} \text { PRIMARY INCOME }_{t-1} \\
& +\beta_{14} \text { IIRA }_{t}+\beta_{15} D U M M Y_{t}+\beta_{16} A R(1)_{t}+\epsilon_{t}
\end{aligned}
$$

Based on the regression results, it can be concluded that Indonesia's trade balance and financial account have a significant impact on the exchange rate on $\alpha 0.1$ with a negative coefficient (the surplus of financial account caused rupiah to appreciate). In contrast, lira and crisis dummy have a significant positive effect on exchange rates (Lira depreciation followed by rupiah depreciation, and crisis dummy caused rupiah to depreciate) (Table 11).

$$
L O G\left(E X C H \_R A T E\right)_{t}=\alpha_{10}+\beta_{11} T B_{t}+\beta_{12} L O G(M 2)_{t}+\beta_{13} D U M M Y_{t}+\beta_{14} A R(1)_{t}
$$

Based on Table 12, it can be concluded that broad money (M2) and dummy variables significantly influence the exchange rate. Thus, if there is a higher amount 


\begin{tabular}{|c|c|c|c|}
\hline Country & Equity & Bond & Bank \\
\hline Turkey & 0.56 & 0.42 & 0.42 \\
\hline Argentina & 0.37 & 0.14 & 0.32 \\
\hline Indonesia & 0.51 & 0.69 & 0.43 \\
\hline South Africa & 0.46 & 0.58 & 0.50 \\
\hline Israel & 0.17 & 0.36 & -0.03 \\
\hline Brazil & 0.58 & 0.52 & 0.46 \\
\hline Chile & -0.06 & 0.15 & 0.19 \\
\hline Colombia & 0.16 & 0.02 & 0.23 \\
\hline Mexico & 0.30 & 0.38 & 0.27 \\
\hline Peru & 0.27 & 0.33 & 0.45 \\
\hline Uruguay & -0.09 & 0.44 & 0.02 \\
\hline Venezuela, Rep. Bol. & -0.06 & 0.29 & -0.18 \\
\hline India & 0.67 & 0.16 & 0.23 \\
\hline China PR: Mainland & 0.41 & -0.08 & 0.57 \\
\hline Korea & 0.49 & 0.27 & 0.43 \\
\hline Malaysia & 0.38 & 0.29 & 0.45 \\
\hline Pakistan & 0.90 & 0.40 & 0.12 \\
\hline Philippines & 0.64 & 0.36 & 0.19 \\
\hline Thailand & 0.58 & 0.36 & 0.40 \\
\hline
\end{tabular}

Source: Claessens [27].

Table 10.

Results of variance decompositions.

\section{Current Account and Financial Account} 2012Q1-2018Q4 (Million USD)

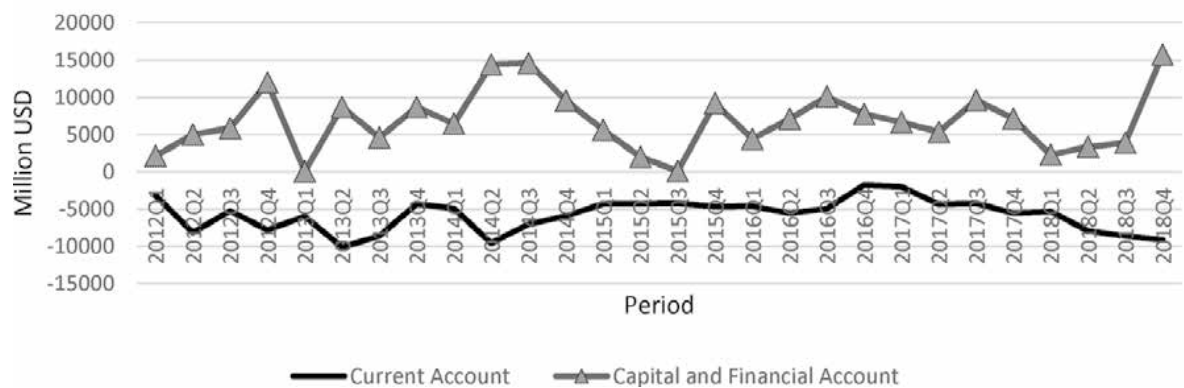

Figure 12.

Current account and financial account 2012Q1-2018Q4. Source: Economics and Finance Statistics, Central Bank of Indonesia.

of money circulating in the community, then there is a decline in the rupiah exchange rate.

$$
\begin{aligned}
L O G\left(E X C H \_R A T E\right)_{t}= & \alpha_{10}+\beta_{11} \text { FINANCIAL }_{t}+\beta_{12} \text { COMPRICE }_{t}++\beta_{13} L O G(M 2)_{t} \\
& +\beta_{14} \text { DUMMY }_{t}+\beta_{15} A R(1)_{t}+\epsilon_{t}
\end{aligned}
$$


Contagion, Exchange Rate, and Financial Volatility: Indonesian Case in Global Financial... DOI: http://dx.doi.org/10.5772/intechopen.92275

Based on the table above, it can be concluded that the commodity price variable is significant at a significance level of $5 \%$. The impact of commodity price to exchange rate is negative; thus when there is an increase in commodity prices by $1 \%$, the value of the rupiah will appreciate by $0.876 \%$. On the other hand, the broad money and crisis dummy have a significant and positive coefficient, which means that if money supply increases and crisis happens, rupiah exchange rate will depreciate (Table 13).

$$
\begin{aligned}
\text { EXCH_RATE }_{t}= & \alpha_{10}+\beta_{11} \text { TB }_{t}+\beta_{12} \text { FINANCIAL }_{t}+\beta_{13} \text { PRIMARY INCOMEt }-2 \\
& +\beta_{14} \mathrm{ARS}_{t}+\beta_{15} D U M M Y_{t}+\beta_{16} A R(1)_{t}+\epsilon_{t}
\end{aligned}
$$

Table 14 shows that financial accounts significantly influence the exchange rate at a significance level of $10 \%$ with a negative direction. The increase in financial

\begin{tabular}{|c|c|c|}
\hline Variable & Coef. & Prob \\
\hline $\mathrm{C}$ & 8450.149 & 0.000 \\
\hline $\mathrm{TB}(-1)$ & -0.052 & $0.078^{*}$ \\
\hline FINANCIAL $(-1)$ & -0.016 & $0.095^{*}$ \\
\hline PRIMARY_INCOME (-1) & -0.071 & 0.256 \\
\hline LIRA & 9.022 .642 & $0.000^{* * *}$ \\
\hline DUMMY & $1,084,258$ & $0.003^{* * *}$ \\
\hline $\mathrm{AR}(1)$ & 0.872 & $0.000^{* * *}$ \\
\hline $\operatorname{Adj} R^{2}$ & & 0.968 \\
\hline Prob (F-stat) & & 0.000 \\
\hline $\begin{array}{l}{ }^{*} \text { Significant at } \alpha 0.1 . \\
{ }^{* *} \text { Significant at } \alpha 0.05 . \\
\text { Significant at } \alpha 0.01 \text {. } \\
\text { Source: Authors, } 2019 .\end{array}$ & & \\
\hline
\end{tabular}
accounts surplus can cause rupiah appreciation. The condition of the peso exchange

Table 11.

Exchange rate determination regression results - Full model with lira variables.

\begin{tabular}{lcc}
\hline Variable & Coef. & Prob \\
\hline C & 7937.000 & 0.000 \\
\hline TB & 0.000 & 0.103 \\
\hline LOG(M2) & 0.089 & $0.061^{*}$ \\
\hline DUMMY & 0.155 & $0.002^{* * *}$ \\
\hline AR (1) & 0.787 & $0.000^{* * *}$ \\
\hline Adj R & & 0.917 \\
\hline Prob (F-stat) & & 0.000 \\
\hline $\begin{array}{l}{ }^{*} \text { Significant at } \alpha 0.1 . \\
{ }^{* *} \text { Significant at } \alpha 0.05 . \\
{ }_{* * *} \text { Significant at } \alpha 0.01 .\end{array}$ & \\
Source: Authors, 2019. & & \\
\hline
\end{tabular}

Table 12.

Exchange rate determination regression results - Trade balance only. 


\begin{tabular}{lcc}
\hline Variable & Coef. & Prob \\
\hline C & 8.854 & 0.005 \\
\hline FINANCIAL & -0.000 & 0.144 \\
\hline LOG(COMPRICE) & -0.876 & $0.016^{* *}$ \\
\hline LOG(M2) & 0.298 & $0.062^{*}$ \\
\hline DUMMY & 0.094 & $0.016^{* *}$ \\
\hline AR (1) & 0.946 & $0.000^{* * *}$ \\
\hline Adj ${ }^{2}$ & & 0.950 \\
\hline Prob (F-stat) & & 0.000 \\
\hline $\begin{array}{l}* \text { Significant at } \alpha 0.1 . \\
* * \text { Significant at } \alpha 0.05 .\end{array}$ & & \\
$* * *$ Significant at $\alpha 0.01$. & & \\
Source: Authors, 2019. & & \\
\hline
\end{tabular}

Table 13.

Exchange rate model: Financial flows only.

\begin{tabular}{lcc}
\hline Variable & Coef. & Prob \\
\hline C & $10,250,890$ & 0.000 \\
\hline TB $(-1)$ & -0.049 & 0.149 \\
\hline FINANCIAL $(-1)$ & -0.019 & $0.072^{*}$ \\
\hline PRIMARY_INCOME $(-1)$ & -0.077 & 0.286 \\
\hline ARS & $5,932,025,000$ & $0.081^{*}$ \\
\hline DUMMY & $1,091,684,000$ & $0.011^{* *}$ \\
\hline AR $(1)$ & 0.923 & $0.000^{* * *}$ \\
\hline Adj $\mathrm{R}^{2}$ & & 0.957 \\
\hline Prob (F-stat) & & 0.000 \\
\hline
\end{tabular}

"Significant at $\alpha 0.1$.

** Significant at $\alpha 0.05$.

*** Significant at $\alpha 0.01$.

Source: Authors, 2019.

Table 14.

Exchange rate determination regression results: Full model with Argentina variables.

rate has a positive association with rupiah exchange rate. If the peso depreciates to the dollar by one unit, the rupiah will depreciate too. The significance of Argentina peso is in $10 \%$ level of significance. Compared to lira regression in Table 11, the significance of lira is in $1 \%$ level of significance, which has the interpretation that Turkey has been proven to have larger potential effects to Indonesian financial sector than Argentina. In addition, the crisis dummy variables significantly influence the exchange rate with a positive direction, which means that crisis has caused rupiah to depreciate.

$$
\begin{aligned}
& L O G\left(E X C H \_R A T E\right)_{t}=\alpha_{10}+\beta_{11} T_{t}+\beta_{12} \text { FINANCIAL }_{t} \\
& +\beta_{13} \text { PRIMARY INCOME } E_{t-2}+\beta_{14} \mathrm{LOG}(M 2)_{t} \\
& +\beta_{15} D U M M Y_{t}+\beta_{16} A R(1)_{t}+\epsilon_{t}
\end{aligned}
$$


Contagion, Exchange Rate, and Financial Volatility: Indonesian Case in Global Financial... DOI: $h$ ttp://dx.doi.org/10.5772/intechopen.92275

\begin{tabular}{|c|c|c|}
\hline Variable & Coef. & Prob \\
\hline $\mathrm{C}$ & 6.443 & 0.001 \\
\hline TB & -0.000 & 0.247 \\
\hline FINANCIAL & -0.000 & $0.060^{*}$ \\
\hline PRIMARY_INCOME (-2) & -0.000 & 0.1715 \\
\hline LOG(M2) & 0.187 & 0.126 \\
\hline DUMMY & 0.103 & $0.018^{* *}$ \\
\hline $\operatorname{AR}(1)$ & 0.912 & $0.000^{* * *}$ \\
\hline $\operatorname{Adj} R^{2}$ & & 0.952 \\
\hline Prob (F-stat) & & 0.000 \\
\hline \multicolumn{3}{|l|}{${ }^{*}$ Significant at $\alpha 0.1$. } \\
\hline \multicolumn{3}{|l|}{ "Significant at $\alpha 0.05$} \\
\hline $\begin{array}{l}\text { "**significant at } \alpha 0.01 \text {. } \\
\text { Source: Authors, } 2019 .\end{array}$ & & \\
\hline
\end{tabular}

Table 15.

Exchange rate model: full BOP component.

If all BOP component included in the regression of Rupiah exchange rate model (Table 15), only financial account and crisis dummy that significantly affect rupiah exchange rate.

\section{Conclusion and discussion}

The empirical result shows the potential contagion from Argentina and Turkey's financial crisis to the Indonesian economy, especially to the stock market and exchange rate. The contagion from Argentina and Turkey in the stock market has been stronger than the exchange rate. The correlation between Indonesia's stock market with Turkey's is higher than the correlation with Argentina's stock market.

Regression results also show that Indonesia's financial account, money, and commodity prices significantly affect exchange rates with different significance and magnitude. Regarding the exchange rate model, the Indonesian exchange rate, explained by the exchange rate of rupiah against the US dollar, has a strong positive association with the Turkish lira and Argentine peso exchange rate. The regression result also shows that Turkey has higher financial contagion effect than Argentina to Indonesian financial market. Indonesia and other emerging markets should be careful with the potential of financial contagion that has a probability to harm real sector activity. Policy anticipation to financial contagion should be taken as well as the structural fundamental policy to repair balance of payment and current account sustainability.

\section{Acknowledgements}

Special thanks also go to the working group member of data dan input support, Herry Gunawan, Ade Holis, Marhamah Muthoharoh, Muhammand Nalar, and Firdha Najiwa and to our research assistants Jonathan Aldo and Indria Nurhakim for their data processing help. 


\section{Author details}

Telisa Falianty $^{1 *}$ and Arif Budimanta ${ }^{2}$

1 Faculty of Economics, Department of Economics, Universitas Indoensia, Jakarta, Indonesia

2 Sigma Phi Policy Research and Data Analyst, Jakarta, Indonesia

*Address all correspondence to: telisa.aulia@ui.ac.id

\section{IntechOpen}

(C) 2020 The Author(s). Licensee IntechOpen. This chapter is distributed under the terms of the Creative Commons Attribution License (http://creativecommons.org/licenses/ by/3.0), which permits unrestricted use, distribution, and reproduction in any medium, provided the original work is properly cited. (c) BY 


\section{References}

[1] Saxton J. Argentina's economic crisis: Causes and cures. Joint Economic Committee. 2003:202-224

[2] Nelson RM. Argentina's Economic Crisis. Congressional Research Service Paper; 2018

[3] Oyvat C. The End of Boom and the Political Economy of Turkey's Crisis. Greenwich Papers in Political Economy 21403, University of Greenwich; 2018

[4] World Bank. Current account balance (\% of GDP). 2019a. Available from: https://data.worldbank.org/ indicator/BN.CAB.XOKA.GD.ZS? locations $=$ ID

[5] Trading Economics. Argentina Economic Indicators. 2019a. Available from: https://tradingeconomics.com/ argentina/indicators

[6] Trading Economics. Indonesia Economic Indicators. 2019b. Available from: https://tradingeconomics.com/ indonesia/indicators

[7] Trading Economics. Turkey Economic Indicators. 2019c. Available from: https://tradingeconomics.com/ turkey/indicators

[8] World Bank. Foreign direct investment, net outflows (\% of GDP); 2019b

[9] Dornbusch R, Park YC, Claessens S. Contagion: Understanding how it spreads. The World Bank Research Observer. 2000;15(2):177-197

[10] Pericoli M, Sbracia M. A primer on financial contagion. Journal of Contagion, Exchange Rate, and Financial Volatility: Indonesian Case in Global Financial. 2003;17(4):571-608. DOI: 10.1111/1467-6419.00205

[11] Forbes K, Rigobon R. Contagion in Latin America: Definitions, measurement, and policy implications. In: NBER Working Paper, Vol. 7885; 2001. DOI: $10.3386 /$ w7885

[12] Masson P. Contagion: Monsoonal Effects, Spillovers, and Jumps Between Multiple Equilibria (No. WP/98/142); 1998

[13] Masson P. Contagion:

Macroeconomic models with multiple Equilibria. Journal of International Money and Finance. 1999; 18:587-602

[14] Forbes KJ, Rigobon R. No contagion, only interdependence: Measuring stock market comovements. The Journal of Finance. 2002;57(5):2223-2261. DOI: 10.1111/0022-1082.00494

[15] Kaminsky GL, Reinhart CM, Vegh CA. The unholy trinity of financial contagion. Journal of Economic Perspectives. 2003;17(4):51-74

[16] Fratzscher M. Working Paper No. 139 on Currency Crises and Contagion; 2002

[17] Allen F, Gale D. Financial contagion. Journal of Political Economy. 2000; 108(1):1-33

[18] Claessens S, Forbes K. International financial contagion: The theory, evidence and policy implications. The IMF's Role in Emerging Market Economies: Reassessing the Adequacy of Its Resources. 2004. Available from: http://web.mit.edu/ kjf orbes/www/Shorter Articles/International FinancialContagion-Theory\%26 Evidence.pdf

[19] Kibritcioglu B, Kose B, Ugur G. A Leading Indicators Approach to the Predictability of Currency Crises: The Case of Turkey. General Directorate of Economic Research The Undersecretariat of Treasury, Ankara, 
Turkey, SSRN; 2001. DOI: 10.2139/ ssrn.283132

[20] Krugman P. Balance sheets, the transfer problem, and financial crises. International Tax and Public Finance. 1999;6:459-472

[21] Sensoy A, Sobaci C. Effects of volatility shocks on the dynamic linkages between exchange rate, interest rate and the stock market: The case of Turkey. Economic Modelling. 2014;43 (September 2008):448-457. DOI: 10.1016/j.econmod.2014.09.005

[22] Clark PB, Tamirisa N, Wei S. A New Look at Exchange Rate Volatility and Trade Flows a New Look at Exchange Rate. IMF Occasional Paper, No 235, Washingthon DC; 2004

[23] Kawai M, Newfarmer R, Schmukle S. Crisis and Contagion in East Asia. World Bank Policy Research Working Papers; 2001

[24] Iriana R, Sjöholm F. Indonesia's economic crisis: Contagion and fundamentals. Developing Economies. 2002;40(2):135-151. DOI: 10.1111/ j.1746-1049.2002.tb01004.x

[25] Gujarati DN. Basic Econometrics. 4th ed. The McGraw-Hill Companies. McGraw Hill; 2004

[26] Engle R. Dynamic conditional correlation - A simple class of multivariate GARCH models. Journal of Business \& Economic Statistics. 2002; 20(1999):1-34

[27] Claessens S. Macroprudential and Capital Flows Management Policies in a World with Demand for Safe Assets. South African Reserve Bank Conference; October 2016 


\title{
State Capitalism in Belarus: Behind Economic Anemia
}

\author{
Kiryl Rudy
}

\begin{abstract}
Belarus' economic model looked rather successful in the late 1990s and in the 2000 s with its economic growth above $7 \%$ per year. But during the last decade, Belarusian annual economic growth has fallen at the average level around $1 \%$ per year. This chapter reveals the rarely known case of state capitalism in this post-Soviet country with its specific indicators, and instruments behind economic anemia. It also outlines several traps on the way of Belarusian economic growth: "debt trap," "middleincome trap," "social burden trap," "resource curse trap," "conflict neighbors trap," and "forceful pressure trap." These pitfalls lead to the long-term economic slowdown in the Republic of Belarus. The consequences of such economic anemia bring to another discussion about the role of public values in support of state capitalism in Belarus.
\end{abstract}

Keywords: transition economy, economic development, growth

\section{Introduction}

Belarus is the former Soviet Union republic with the inherited economic structure and un-reformed government management. In the 1990s, this medium-sized European country took its first steps on its own, and it has spent the intervening decades sticking closely to the choices it made then. The Belarusian economy was naturally evolving. The private sector was developing, and small business as well as the service industry was growing. On the other hand, the efforts being made to preserve old state-owned manufacturing and the mobilization model were limiting the economy's flexibility.

In the last decade, Belarusian economy skidded to a near-complete halt. Budget spending, devaluations, and debt no longer help fuel economic growth. The system of incentives in place for state-owned enterprises is holding back initiative and innovation, and the continuous flow of state capital conceals mistakes in management. But the problem runs deeper: the consistently preferential treatment enjoyed by the public sector drives costs higher and keeps market resources out of the hands of the private sector, strangling its development as well. All of that saps energy and enthusiasm in the country and throws it to the long-term economic anemia.

State capitalism in Belarus has its own logic, a clear desire to keep (even by force) the inherited structure and system of management. That gives a mental support point, instills self-confidence, and permissiveness. Currently, there are no economic reforms to boost growth in political agenda. Manual management of the economy is so overwhelming that it leaves neither strength nor time for strategic decisions, and with the new generation has come a shift from nostalgia-a tendency to look for the future in the past- to uncertainty. The lack of reforms is also explained by an unwillingness to take responsibility for the social fallout. That psychological barrier 
can only be overcome by recognizing the inevitability of transformation; it is selfawakening that will illuminate the path forward for reforms.

This chapter includes several parts. The next one provides overview of state capitalism in Belarus, its indicators, and instruments. Another one describes pitfalls faced by state capitalism in Belarus and the reasons behind its economic anemia. The last one shows how Belarusian state capitalism is supported by the public during economic growth, and how public values are transformed during economic anemia.

\section{State capitalism in Belarus: overview of indicators and instruments}

The Republic of Belarus features an unstable hybrid economy. On the one hand, the country features state ownership of large swaths of property, administrative (manual) control over state-owned enterprises and state-owned banks, directed lending, consolidated budgetary resources, and wide social security. On the other, it has its entrepreneurs, small and medium businesses, private and foreign businesses, an international banking sector, a free-floating exchange rate, market prices, elements of a public-private partnership, a functioning Hi-Tech Park, an industrial park "Great Stone," free economic zones, and other aspects of a market economy.

The hybrid regime of the Belarusian economy sometimes reminds of other countries: modern Russia [1], other post-Soviet countries [2], and China at one point in its development [3]. The resemblance is especially clear when talking about the active role played by the government in a market economy, something generally referred to as state capitalism [4]. State capitalism is understood here to be an economy in which the state plays the main role as entrepreneur, employer, owner of the means of production, and profit allocator.

Belarus' state capitalism can be described through six indicators how the state intervenes in the economy, and how the capital is distributed.

1. Public expenditures to GDP: This indicator shows how consolidated budgetary funds are in an economy. In Belarus in 2010-2019, they were at an average around $30 \%$ of GDP, though adding in social security pushes that number to an internationally recognized $40 \%$ of GDP. Budget is the main tool and indicator of state capitalism in Belarus. It redistributes much higher share of capital in economy by way of comparison with other countries: Central and Eastern Europe registered at 34\%; and Brazil, India, Korea, Malaysia, Singapore, and South Africa at an average of 22\% [5].

2. Tax burden: Belarus enjoys a lighter tax burden than many developed countries. In 2019 tax revenue, including social spending, came to $37 \%$ of GDP. Tax burden, without social spending, was $25 \%$ in 2019 and stayed flat since 2016 [6].

Developed countries saw that same number range from 33 to $55 \%$ from 2000 to 2019. Interestingly, from 1870 to 1910 in developed countries, it was as low as $7-8 \%$ and was sufficient for governments to pay for security, legal systems, foreign services, and everything else the public needed [7]. The growth in tax revenue experienced by those countries since then has primarily served to cover spending on social programs and infrastructure. For the same reason, Belarus has a fairly high tax burden, with around $12 \%$ of GDP going to social security.

3. Money supply to GDP: In Belarus, the ratio of money supply (aggregator M2) to GDP is quite low around $16 \%$ in 2019, especially if it is compared with Chinese indicator of more than $200 \%$, or Russian-around $60 \%$. This ratio has been increasing in Belarus annually with the speed of 13\% in 2016 to $18 \%$ in 
2019, but still lower than in 1996-2015 with the spread from 20 to 60\% increase in different years, which boost double-digit inflation, rapid devaluation, and economic growth.

4. Banking assets to GDP: Banks are usually the significant elements of state capitalism in different countries. For example, the share of banking assets to GDP in Russia is around 90\%; in China, it is almost 300\% [8].

However, the banking system in Belarus does not satisfy the country's economic needs, meaning that is suffers from chronic undercapitalization. In 2013, the Belarusian banking system commanded assets equaling a bit more than $60 \%$ of GDP; in 2019-20, it is 57\%.

5. Financial market to GDP: Due to the lack of privatization and relatively small number of private enterprises in Belarus, national financial market is rather underdeveloped. In 2019, the capitalization of Belarusian financial market to GDP was 22.6\%, including stock market to GDP was only $0.6 \%$.

By the comparison of state capitalism in China, this indicator was more than $100 \%$ to GDP there in 2019 , and stock market capitalization was $46.5 \%$ falling from $71.7 \%$ in 2017.

6. Foreign direct investments to GDP: As the important source to finance balance of payments and economic growth, foreign direct investments inflow in Belarus were at the average annual level around 2.3\% to GDP in 2016-2019. This ratio is similar to Chinese one in recent years, but not in the 2000-2010 when it overcame 4\%.

According to the estimation of Economy Research Institute of the Ministry of Economy of Belarus in 2015, USD 9.3-9.6 billion of foreign direct investments are to be mobilized in 2016-2020 on a net basis to attain the GDP growth of 10-15\% over the 5 years (2-3\% per year). In fact, USD 5.2 billion of foreign direct investments were attracted in 2016-2019, and GDP growth was on the average level of 1.1\% per year.

The main two instruments of state capitalism in Belarus are state-owned enterprises and state-owned banks.

\subsection{State-owned enterprises in Belarus}

From the Soviet times, it is believed in Belarus that economy could be run as if it were a single state-owned corporation and thus managed more efficiently. The government participates in the day-to-day management of individual state-owned companies by setting goals, approving business plans, helping organize sales, unloading warehouses, continually monitoring operations, attracting financing for agriculture, and running social projects, sports, and more.

State and local authorities often serve as anti-crisis managers, actively intervening and periodically offering support to state-owned firms. For example, in 2015, the government and the National Bank (central bank of Belarus) took control of the business plans for 106 of them with the heaviest external debt burdens. Anticrisis management encompasses the use of a number of financial tools: tax breaks, short-term loans, debt restructuring, loan servicing, and more. The problem is that a conflict of interests necessarily arises between the Ministry of Finance and the Ministries responsible for a particular state enterprise.

The government not only provides financial support but also requests additional financial payments besides taxes from the profitable state-owned enterprises. In 
2005, Belarus has founded a targeted national development fund. It accumulates capital from revenue appropriated from highly profitable state-owned enterprises based on their yearly results. The list of firms and the amount appropriated are set each year. In 2020, 40 state-owned enterprises redirected part of their earnings to the fund, and the primary contribution, which was made by the Belarusian Potash Company, made it based on raw materials. However, the fact that contributions are made by state-owned enterprises unrelated to raw materials weakens their incentive to boost productivity. The fund also receives foreign-denominated contributions earned by selling state-owned shares to foreign investors.

The focus of the Belarusian government on the state-owned enterprises put the doubts on the efficiency of such management system as this sector covers only half of national GDP. The similar share of state-owned enterprises around 50\% to GDP is in Russian state capitalism. In China, state-owned companies take up only around 30\% of GDP [9]. Another way of looking at this issue is to evaluate the other contributions of state-owned enterprise in Belarus: to foreign exchange earnings (about 30\% in 2019), industry production (73.3\%), retail turnover (16.2\%), and revenue (58\%) [10].

The close relationship between public and private business in Belarus makes it difficult to objectively determine the role played by the public side of that partnership independent of its private counterpart. State-owned enterprises support an entire ecosystem comprised of hundreds of smaller state-owned, private, and foreign suppliers, contractors, and intermediaries. In keeping with international terminology, companies critical to the economy vis-à-vis manufacturing, taxes, exports, and employment are designated "national champions." However, the fact that they are occasionally forced to lay off employees, reduce production, and rely on tax breaks to maintain competitiveness means that the list of Belarusian national champions sometimes changes.

The role of state-owned enterprises in job creation deserves a separate look due to its economic and social importance for Belarus. State-owned companies made up 43.4\% of employment in Belarus as of January 1, 2020, 39\% of employment in Russia, and 19\% of employment in China. The high percentage of employment generated by state-owned companies in Belarus is in large measure due to how connected they are to individual cities, something left over from the Soviet Union. From a social point of view that makes them essential and from an economic point of view, it keeps labor resources sticky and puts a damper on overall labor productivity across wide swaths of territory. High employment at state enterprises in Belarus can be seen as providing social security in the form of guaranteed jobs (lifetime employment). However, companies incapable of holding up on their own under intense competition cannot provide that security to their employees. Counting on the government to continually prop them up can distort public finances and lead to problems for other public services, also preventing manpower from migrating to industries characterized by higher added value and stronger economic growth.

\subsection{State-owned banks in Belarus}

The lion's share of the Belarusian banking system is occupied by two stateowned banks: Belarusbank and Belagroprombank. They participate in state programs and offer state support, commanding a monopoly of the banking system vis-à-vis assets (62.2\% between them as of April 1, 2020) and capital (60.4\%) [11].

The low profitability that comes with state programs and support ranks stateowned banks among the country's worst large banks in terms of asset profitability and capital. As of January 1, 2020 the profitability of assets after taxes of state-owned banks in Belarus was 1.3\%. The same indicator of the banks with foreign capital in Belarus was $2.3 \%$, and the banks with private national capital-3.9\%. In general, it is necessary to mention that banks with foreign capital play important role in economic 
growth of Belarus as they fuel the money in the fast-growing private and international companies in the country. As of January 1, 2020 the foreign-capital banks' assets was $34.6 \%$ to Belarus' GDP, and their capital was 34.9\% to GDP. It is different from other state capitalism models. In China, these indicators are not higher than $2 \%$.

Administrative meddling in the day-to-day operations of state banks by oversight boards often leads to directed lending that does not take the bank's reserves into consideration, creating liquidity issues. Directed lending also relieves banks of responsibility for channeling funds to underperforming projects. When the general economic situation worsens or revenue dries up, companies no longer have the ability to service the loans held by banks. The continually changing outlook also ensures a constant stream of bank customers switching their accounts to and from rubles as well as into and out of the banking system, draining bank reserves. All those factors intensify the systemic risks faced by banks, and a state infusion of capital or moving toxic assets to the Development Bank or public debt when directed lending is relaxed serves as only a temporary reprieve for the banking system.

In 2011, the Development Bank of Belarus was founded as a non-banking institution designed to improve the economic performance of government investment programs. From December 2011 to June 2013, Belarusbank and Belagroprombank handed over some of their state program assets to the newly founded institution, altogether totaling more than 12 trillion rubles. They did hold onto some old loans and continue lending directly to government programs.

As of 2019 an old mechanism for funding state programs in Belarus was still in place, though it keeps the Development Bank from being able to perform its primary function. If that mechanism changes or a competitive, a result-based approach is taken to distributing funds, the Development Bank can transition to the traditional format employed by development banks in other countries (for example, in Germany, China, and Russia). The Belarusian Development Bank could then focus on providing export finance, financing major infrastructure projects, supporting small and medium business, and others of the country's priority goals.

Thus, state capitalism in Belarus characterized by high level of public expenditures to GDP, medium tax burden, decreased monetization of GDP, undercapitalized banking system, underdeveloped financial market, and low inflow of foreign direct investments. Its main tools are state-owned enterprises and state-owned banks. However, state capitalism in Belarus is a hybrid regime, as it covers only half of national GDP. It is proved by such metrics like share of state-owned enterprises to GDP, the share of employment at state-owned enterprises, and the share of stateowned banks in banking system assets and capital.

The evaluation of state capitalism efficiency in Belarus based on economic growth provides contradictive results (Table 1 ). There was stable economic growth in Belarus above global average in 1996-2010. The main economic drivers were on the one hand consumption and investment, and on the other hand manufacturing and agriculture. The high inflation in that period signaled about misbalancing in monetary and external spheres. The current account deficit and rise of gross external debt proved that. The IMF holds factors of production responsible for $70 \%$ (of which capital created $55 \%$ and labor $45 \%$ ) of growth in output, while productivity came in at around $23 \%$ [12]. Other calculations estimate the average contribution of capital to growth from 2006 to 2012 to be $98.3 \%$, accompanied by capacity utilization at $8.3 \%$, labor at $-5.3 \%$, and productivity at $-1.4 \%$ [13]

In the last decade, economic growth was trapped in the long-term anemia around $1 \%$ average per year. The role of manufacturing and agriculture in pushing the economic growth decreased with the rise of service sectors. The improvements in financial stability and external balances have happened in recent years. 


\begin{tabular}{lccccc}
\hline & $\mathbf{1 9 9 6 -}$ & $\mathbf{2 0 0 1 -}$ & $\mathbf{2 0 0 6 -}$ & $\mathbf{2 0 1 1 -}$ & $\mathbf{2 0 1 6 -}$ \\
& $\mathbf{2 0 0 0}$ & $\mathbf{2 0 0 5}$ & $\mathbf{2 0 1 0}$ & $\mathbf{2 0 1 5}$ & $\mathbf{2 0 1 9}$ \\
\hline GDP growth & $\mathbf{6 . 3}$ & $\mathbf{7 . 5}$ & $\mathbf{7 . 3}$ & $\mathbf{1 . 2}$ & $\mathbf{1 . 1}$ \\
\hline GDP growth, global & 3.7 & 3.6 & 3.5 & 3.6 & 3.4 \\
\hline Consumer price index growth & 128.5 & 25.7 & 10.4 & 35.0 & 6.7 \\
\hline Current account deficit to GDP & -4.1 & -2.3 & -9.3 & -6.3 & -1.7 \\
\hline Gross external debt to GDP & 15.8 & 22.5 & 33.4 & 51.6 & 44.2 \\
\hline Consumption to GDP & 78.0 & 77.1 & 70.5 & 64.2 & 71.4 \\
\hline Investment to GDP & 25.2 & 25.6 & 28.9 & 35.1 & 27.9 \\
\hline $\begin{array}{l}\text { Net exports of goods and services to } \\
\text { GDP }\end{array}$ & -4.1 & -2.2 & -8.6 & -0.1 & 0.5 \\
\hline Manufacturing to GDP & 28.4 & 26.8 & 26.2 & 23.0 & 21.0 \\
\hline Agriculture and forestry to GDP & 13.1 & 9.3 & 8.5 & 7.3 & 7.0 \\
\hline Construction to GDP & 5.6 & 6.2 & 8.9 & 8.4 & 5.4 \\
\hline $\begin{array}{l}\text { Transportation and communications } \\
\text { to GDP }\end{array}$ & 10.8 & 9.8 & 8.5 & 8.8 & 10.9 \\
\hline Trade and food services to GDP & 8.6 & 9.8 & 10.9 & 13.8 & 11.3 \\
\hline
\end{tabular}

Table 1.

Average annual macroeconomic statistics for Belarus, \% [10, 11].

They provided proper environment to increase the quality of capital in Belarusian economy, but not its necessary quantity. The economic anemia can be explained by taking a closer look at the traps facing Belarusian state capitalism.

\section{State capitalism traps in Belarus}

\subsection{The “debt trap"}

The "debt trap" appears when old debts are converted into new ones. As American economist Irving Fisher put it at the time of the Great Depression, "the more debtors pay, the more they owe." The same happens in Belarus. Belarus' external government debt is not repaid with proceeds from its use, and is partially refinanced, being shifted to the future. Non-project-related government loans are used to replenish reserves, to refinance old debts, and do not generate foreign exchange proceeds through exports and foreign direct investments.

Due to the nature of state capitalism in Belarus, "debt trap" appeared on the road of country's development. The problems with business plan appraisal and monitoring, project-related external government loans and guarantees do not always generate foreign exchange proceeds either, and are sometimes repaid by the budget rather than by the projects. In turn, external debt refinancing with the more expensive domestic debt leads to an increase in the size of the aggregate government debt and an outflow of foreign exchange from the country, due to the weakening of banks' resource base and the declining foreign exchange savings of households.

"Debt trap" is locking when the debt rule is broken-"government loans should stimulate economic growth, and the rate of economic growth should exceed that of government debt." In 2015-2016, the increase in the government debt in Belarus was accompanied by a fall in its GDP. As a result, the ratio of government debt to GDP increased in Belarus from 22.3\% as of 1 January 2015 to 39.4\% as of 1 January 2017. But, in view of the fact that Belarusian government debt is mainly denominated in foreign currency, the key indicators for payments related thereto include net 
exports, foreign direct investment, and the ability to attract new loans. When the first two parameters decrease, the main focus becomes new loans.

"Debt trap" brings to default when the inflow of new loans stops. It is symbolic that in economic theory this point is called the "Minsky Moment," after American economist Hyman Minsky, the son of Belarusian emigrants, who took the surname Minsky in honor of the city of Minsk upon their arrival in the USA. According to his theory, which regained its popularity after the 2008 mortgage crisis in the USA, there are three types of borrowers. Those belonging to the first type hedge their risks, manage flows, and can avoid default. Those of the second type are only able to pay interest on loans but cannot repay the principal amount. The third type cannot rely on their cash flows, but only on the growing value of their assets. The "Minsky Moment" comes when the asset value stops growing.

Belarus as a borrower can be superficially classified under the first type. But it has a specific feature, and if this is factored in, Belarus moves closer to the second type of borrower. Faced with a limited range of external creditors, Belarus de facto focused on borrowing from a single creditor in recent years. The new external loans mobilized from Russian banks, the EAEC Fund and the Government of Russia, are actually controlled by one creditor. It narrows the space for maneuver in government debt management and creates new risks. The worst thing in case of problems with several creditors is a default and the loss of access to the international financial market for 3 to 4 years; with one creditor it is a matter of sovereignty.

Until 2012, Belarus attracted resources from international markets, although these transactions were often predetermined, that is, Belarusian and Russian banks often bought sovereign bonds. After 2012, almost all non-project-related government loans were extended for political reasons. At the same time, government debt management instruments, such as syndicated loans, issuance of municipal, corporate bonds in foreign markets, and so on, were practically never used. In 2017, Belarus once again tapped the international financial market, issuing its Eurobonds worth USD 1.4 billion to refinance old debts and somewhat diversify the pool of its external creditors. In June 2020, Belarus issued sovereign Eurobonds with the amount of USD 1.25 billion.

It is important to note that access to refinancing is generally linked both to economic development and to non-economic factors like overall confidence in the borrower. The problems developing countries have refinancing external debt are therefore of particular interest.

a. Background problems with refinancing (default, or the inability or unwillingness to make debt payments): developing countries see refinancing problems start to occur on average when external debt reaches 69.3\% of GDP [14]. Most often (in $32.3 \%$ of instances) they happen when external debt ranges from 41 to $60 \%$ of GDP, while in $19.4 \%$ of cases it is when external debt is below $40 \%$ of GDP, $16 \%$ when it is between 61 and $80 \%, 16 \%$ when it is between 81 and $100 \%$, and $16 \%$ when it exceeds $100 \%$. The threshold for when a country starts to have problems refinancing external debt can therefore be said with a high degree of accuracy to be when existing debt is around 60\% of GDP. The ceiling, similarly, seems to be $100 \%$.

b. Fallout following default: the main consequences of default are a drop in investor confidence, a lowered sovereign credit rating, and temporary exclusion from international financial markets. Carmen Reinhart and Kenneth Rogoff looked at 169 defaults from 1946 to 2008 and found that it takes countries 3 years on average to move past defaults (again begin to attract foreign loans) [14]. Interestingly, that period seems to be shrinking: from 1800 to 1945 it took countries an average of 6 years to get past 127 defaults. It is also worth remembering that defaults have on occasion led to war. For example, there 
were wars between the UK and Egypt in 1882, the UK and Turkey in 1876, the US and Venezuela in the middle of the 1890s, and the US and Haiti in 1915. The primary objective in each of those cases was to establish military control over customs in order to collect currency as payment for foreign debt.

Given that the primary source of the "debt trap" facing the Belarusian economy is the state capitalism system, opening up the economy to foreign capital and stimulating private investment is the way out of this pitfall.

\subsection{The "middle-income trap"}

The "middle-income trap," also called the "development trap"- term introduced by the World Bank economists I. Gill and H. Kharas [15]. This trap occurs when rising salaries no longer lead to country-fast development as measured by GDP per capita (GNI per capita, Atlas) and the country finds itself trapped on par with other middleincome countries. The borders of the "middle-income trap" start from 1006 USD till 12,235 USD of GNI per capita [16]. Others use nominal GDP per capita to estimate "middle-income trap" in the limits of 10,000 dollars to 15,000 USD [17] or real GDP per capita (purchasing power parity) from 5000 USD to 10,000 USD [18]. There is also the method to compare developing countries' GDP per capital with the same US' indicator and to use it as the share from 5 to $45 \%$ to make conclusions about the pitfall [19].

Using Atlas methodology, it was found out that Belarus got into the "middleincome trap" since its independence and has been there for almost three decades. In 2007, Belarus moved from the group of lower middle-income countries to the group of upper middle-income countries with GNI per capita more than 3956 USD. But it did not go out and made reverse from the exit in 2014, staying in this upper level trap already more than 10 years [20]. The other countries which got into "middleincome" pitfall have been staying there more than 5 years (39 out of 55 countries in the period from 1989 till 2016), and more than 20 years (15 out of 55 countries in the same period). The cases of Russia, Croatia, and Equatorial Guinea prove that countries can go back to the "middle-income trap," even if they left it before.

There are several reasons why Belarus is trapped in the "middle-income" pitfall.

\section{An export-oriented economy}

From 2009 to $2018,31.3 \%$ of manufactured goods and services were exported, with that number climbing to $36.6 \%$ for 2016 and $36.1 \%$ in 2018 [10]. At the same time, the rising cost of labor resources has cut into profits and sabotaged Belarusian competitiveness as compared to countries coupling similar technology with cheaper labor. More importantly, however, those countries themselves are undergoing structural reforms, improving their markets, and developing their institutions, with the effect of entrenching their competitiveness.

\section{Fading innovation}

A lack of spending on research and development, innovation funds that are sometimes not used for their intended purpose, and an overall lack of stimulus for the development of innovation keep Belarusian exporters from focusing on reducing costs and boosting quality in an effort to improve their competitiveness. For example, the share of expenses devoted to R\&D by Belarusian exporters (the Minsk Tractor Works, BelAZ) is several times lower than that of their competitors (John Deer, Caterpillar). In absolute dollar terms, they are outspent thousands of times over. Moreover, Belarusian companies invest in imported technology, while their foreign competitors invest in their own technology. Firms in Belarus purchase high 
quality, if imported equipment that needs to be update 5-10 years later, meaning that they have to again spend the money to purchase foreign tech. That all intensifies the Belarusian race to improve on old technology and leaves no room for companies to create new, cutting-edge technology of their own. Technological progress, in short, stalls. The level of R\&D expenditures to GDP is rather low. It declined from $0.96 \%$ in 2007 to $0.49 \%$ in 2015 and the increased to $0.6 \%$ in 2018 .

The situation with innovation in Belarus has also devalued how people look at research and scientists by chronically underfunding them and leaving their skills unneeded and unwanted. Young doctors of science in Belarus are few and far between. In 2011 and 2012, there was not a single one in the country under the age of 29 . There were 3 and 4, respectively, under the age of 39, 39 and 29 aged 40-49, 71 and 62 aged 50-54, and 114 and 112 aged 55-59 [21].

The IT industry's popularity in Belarus neither compensates for the lack of innovation in the real sector nor contributes to overall labor productivity. Instead, the flow of qualified workers moving to IT from the manufacturing industry sacrifices productivity in the latter without a corresponding boost for the former. But IT as the self-sufficient and export-oriented industry (separated from the rest of the economy) provides rather successful case in Belarus. In 2017, new legislature reloaded High-Tech Park with new tax benefits and state guarantees. As the result, in 2019 IT sector contributed 6.5\% to GDP, and 5.2\% to total export of goods and services.

\section{Low labor productivity}

Salary growth over the long term in Belarus exceeds labor productivity growth multiple times over. For example, from 2000 to 2014, real wages grew 4.8 times, while productivity only grew 2.2 times. From 2010 to 2014, real wages grew 45\%; productivity was held to only $14 \%$ growth.

Admittedly, labor productivity at Belarusian state-owned firms is lower than at their private and foreign competitors. In 2013, revenue per employee at the joint venture MAN factory was 360,000 dollars compared to 64,300 dollars at the Minsk Automobile Plant (6 times higher); at John Deer it was 11 times higher compared to the Minsk Tractor Works; at foreign owned Olivaria Brewery it was 190,700 dollars compared to 85,000 dollars at state-owned Krinitsa (half as much); at private Santa Bremor it was 115,900 dollars compared to 83,700 dollars at state-owned Belryba. It is worth noting that the difference in productivity goes beyond technology, a metric according to which state enterprises are comparable to their competitors after modernization; different management systems-manual versus corporate, for instance-explain the difference.

Belarus can therefore get away from the "middle-income trap" by utilizing systemic and operational measures.

a. Systemic measures, which wield a long-term effect, include altering the country's economy structure, accelerating innovative development, and taking steps to boost labor productivity, primarily at state-owned firms. Management systems could be improved, for example, by implementing IT in the manufacturing industry. The necessity of maintaining living standards for Belarusians makes it imperative to compete with other countries for international capital by improving the institutional and entrepreneurial environment rather than cutting labor costs.

b. Operational measures, which enlarge the labor pool in the short term, include pension reform, getting more women and disabled people into the economy, 
liberalizing immigration policy, and reducing prison sentences (for example, for non-violent crimes).

\subsection{The "social burden trap"}

Belarusian state capitalism has always had the support and understanding of the people as a form of socialism, or a welfare state. Since the 1990s, especially when contrasted to the social turbulence experienced in neighboring countries, Belarusian society held onto a degree of nostalgia for the relatively successful social and economic development Belarus had grown accustomed to as part of the Soviet Union.

And nowadays the government and its limited resources are torn between satisfying the country's growing social needs and solving its economic problems. It generally chooses to prioritize the former at the cost of economic growth. That high level of social spending coupled with the "debt trap" and "middle-income trap" is calling into question whether the social welfare system will be financed in the future by the government, the people, or other sources of income. At the same time, a population that has grown accustomed to today's level of income and social benefits as subsidized by the government expects more of the same.

It is important to also note that the purchasing power of wages in Belarus is higher than its face value in dollars. That can be explained by the partial subsidies the government provides for consumer prices, utilities, and social services. While nominal wages in Belarus are lower, for example, than in Russia and Kazakhstan, in terms of purchasing power parity they have been higher in recent years than in Kazakhstan.

The growth in and level of salaries in Belarus should be juxtaposed with the approaches taken by other countries, for example, to financing utilities or a number of other social expenses aimed at boosting the national economy's competitiveness.

\subsubsection{Utilities}

The government provides a utility subsidy of nearly $70 \%$, and there are plenty of counter-arguments to the impending elimination of cross subsidies.

First, and given the state monopoly in this area leaving consumers bereft of choices when it comes to which utilities they use and pay for, the key issue is to control expenses and therefore rates.

Second, raising rates would increase the percentage of private expenses taken up by utilities. In the first quarter of 2015, utilities accounted for $6.9 \%$ of household expenses in Belarus. By way of comparison, in 2012 that number was $6.8 \%$ in Russia and $9.9 \%$ on average in Europe, with the lowest being 3.5\% in Finland and the highest being $14 \%$ in Slovakia [22]. In other words, completely eliminating cross subsidies in Belarus would be justified given were it to occur in the context of an increase in private earnings.

Third, utility rates are included in the consumer price index, so raising them would have a trickle-down effect that pushes inflation higher across the entire economy. Doing so therefore needs to be gradual in an effort to avoid an inflationary shock.

\subsubsection{Social support}

Social expenditures on, for example, supporting families are higher in Belarus than in other countries. For instance, paid maternity leave in Belarus is 3 years, while in Russia, it is 1.5 years and in Kazakhstan, it is 1 year. The one-time grant given at childbirth is 961 USD in Belarus for the first child and 1345 USD for all following children. In Russia, it is 261 USD; in Poland, it is 266 USD; and in Lithuania, it is 469 USD. In Kazakhstan, parents are paid 319 USD for each of 
their first three children, receiving 53.2 USD for all subsequent children. In 2015, Belarus introduced family capital in the amount of 10,000 USD made available after the birth of third and following children. In Russia, maternity capital comes to 8160 USD, while there is no state-sponsored maternity capital system in Kazakhstan, Poland, or Lithuania.

There is no need to limit the search for ways social spending can be financed to some sort of split between the government and consumers-business could also prove to be an important source. However, social spending is usually seen in the business world as a burden imposed by the government in the form of a minimum wage, educational standards, medical standards, and more. In the 1990s and 2000s, the business model in vogue was to minimize social expenditures by manufacturing in countries with the lowest social requirements and standards: China, Vietnam, Bangladesh, and other Asian countries, for instance.

In Belarus, one strategy for privately owned construction companies is to build kindergartens into their new apartment complexes and hand them over to the local authorities, thereby adding to the incentive to buy their apartments. The cost of building the kindergartens is even built into the price of the apartments. Another example is when companies build roads to their shopping centers, business centers, and entertainment complexes. All of that goes back to a business model focused on stimulating demand for goods and services rather than charity paid by business to finance the state's social infrastructure.

Ultimately, one way out of the "social burden trap" (besides wholesale welfare reform) is a public-private partnership that is both mutually beneficial and voluntary, a qualification without which it would drag business into an unprofitable social sphere and come to nothing. Most practical would be the creation of a fund supported by private, state, and international capital that could be used to finance the public-private partnership's social projects (by offering targeted business loans at discounted rates, for instance).

\subsection{The "resource curse trap"}

This trap occurs when the economy, and in particular exports, is based on preferential access to raw materials, forcing it into dependence on external factors (global prices, foreign trading partners, and competitors) and industries not based on raw materials into the background. Favorable conditions see exports and the economy grow, digging themselves deeper and deeper into the hole in the process, while economic downturns lead to falling exports, economic growth, and living standards. Free or preferential access to raw materials also saps the state's need for tax revenue and strong institutions. When the economy takes a turn for the worse and the prices for raw materials drop, institutions and tax revenue are not there to continue stable economic development.

This pitfall is a real and present danger for the Belarusian economy due to the petrochemical sector's outsized presence and the Russian factor.

\subsubsection{The petrochemical sector}

The petrochemical industry exploited a period of low crude oil prices and high prices on finished products to boost its share of the country's GDP. In 2009, oil refining and chemical production created $4.7 \%$ of GDP; in 2019, they created around $7 \%$. Raw materials also became more of the country's focus when it came to exports. For example, the share of oil, petroleum products, and potash fertilizers in Belarusian exports went from 35\% in 2010 to $38 \%$ in 2014. And even within that number oil and petroleum products went from 26 to $30 \%$, while potash fertilizers dropped from 9 to $8 \%$. 
Falling global potassium prices in 2013-2014 and oil prices in 2014-2015 (a trend that will most likely be deep and protracted) coupled with a lesser fall in prices for petroleum products necessitates a new economic structure for Belarus. A fast bounce-back of global oil prices and a return to the old national economic structure are an unlikelihood not borne out by knowledge of history. The average historical oil price (in terms of the dollar's value in 2000) from 1880 to 2004 was 19.61 USD per barrel [23]. The historic highs enjoyed by the global economy have been a recent phenomenon: in 2010-2014, Brent crude averaged 102 dollars per barrel, creating an unsustainable bubble in the economies of a number of countries. The dramatic drop in oil prices has also had an impact on both production quantities and the financial wellbeing of oil refineries that are Belarus' largest exports and taxpayers and in the middle of modernization. In 2013, the share of exports taken up by goods and services provided by Mozyr Oil Refinery and Naftan was $16 \%$.

On the other hand, the impact dropping crude oil prices have had on the Belarusian oil refinery sector should not be overstated. Prices on crude are correlated with prices on oil refinery goods, so the net profit brought in by oil refineries should remain more or less the same. Efficiency, rather than price changes, is a much heftier driver of profits, and decreased export customs duties have been the biggest difference the oil price drop has had on the Belarusian refining sector.

\subsubsection{The Russian factor}

Russia's oil-based economic structure, the formation of the Eurasian Economic Space, and the orientation of $43 \%$ as of 2019 Belarusian exports toward the Russian market make the Russian factor a critical piece of the puzzle. In 2019, oil was responsible for $48 \%$ of import from Russia to Belarus, adding gas pushes that number to $68 \%$, and adding metals means that the overall share of raw materials came to $78 \%$.

Given the Russian ruble's floating rate, the global collapses of oil prices in 2014-2015, and early 2020 were mirrored almost exactly by the exchange rate. The Russian ruble has been de facto pegged to the price of oil. Certainly, the plummeting price of oil has not been the only factor exerting downward pressure on the Russian ruble. Countries like Angola, Algeria, Kuwait, Iran, Iraq, and Nigeria, all with a higher oil exports to GDP ratio than Russia, saw their currencies devalue less dramatically than the Russian ruble in 2014-2015.

The weakening Russian ruble has a corresponding effect on the competitiveness of Belarusian exports to Russia. Not only that, but given the floating Belarusian ruble rate, the fact that the Russian ruble is in the Belarusian currency basket, and the close economic relationship between Belarus and Russia, changing global oil prices affect the value of the Belarusian ruble as well via currency and trade channels.

All in all, the Belarusian economy's post-Soviet structure, its overbearing focus on the raw materials of the petrochemical and potassium sector, and its close ties to the raw materials-based Russian economy creates the framework for a fall into the "resource curse trap." Norway is a textbook example of how to get out of that trap, as the oil and gas sector there is responsible for more than $50 \%$ of the country's export revenue. Even so, it has maintained stable economic growth-while raw materials and the role they play in exports is an important factor in the country's economic growth, they are not the determining factor. The main difference is that institutions were built in Norway before raw materials were developed on an industrial scale (before the 1970s), making it immune to external shocks today. The way out of the resource curse pitfall, ultimately, means going back to the necessity of institutional reform. 


\subsection{The "conflict neighbors trap"}

The "conflict neighbors trap" term was coined by Paul Collier to describe how countries surrounded by neighbors in conflict fall into the long-term trap of inhibited economic growth [24]. His study showed that, on average, countries benefit from the economic growth of their neighbors: each point of growth adds $0.4 \%$ to the GDP of neighboring countries, though for African countries that number is $0.2 \%$ and for non-African countries it is $0.7 \%$. Political crisis in a country also results in economic losses both for it and for its neighbors totaling an average of 100 billion dollars. The origin of political conflict was also proven to be slow economic growth or contraction in many instances. For example, 5 years of non-existent economic growth leads to political crisis and civil war in $14 \%$ of cases. Each point of growth or contraction improves or lowers the odds of a political crisis occurring. If an economy contracts by $3 \%$, for instance, the likelihood of a crisis happening rises to more than $16 \%$. It was also shown that the longer an economy contracts, the longer it takes to dig itself out of the resulting political crisis. A crisis that culminates in civil war lasts an average of around 5 years, and countries that go through a civil war have a $50 \%$ chance of experiencing another one within the next decade. Economies suffering from civil war contract by an average of $2.3 \%$ per year, pulling their neighbors down with them.

The results of Collier's study have an analogy in the Russian-Ukrainian conflict, the civil war in Ukraine, the 2014-2015 recession, the 2016-2019 slow recovery in Russia, and their impact on the Belarusian economy. Given the territorial losses suffered by Ukraine as well as the human cost of the conflict, a fast resolution to the bilateral conflict looks anything but likely. Taking into the account the consequences of 2020's coronavirus, it is hard to make predictions when Russia will return to growth. While prognoses differ, they share a similar trend: for each point Russian GDP contracts, estimates concur that Belarusian GDP will lose $0.6 \%$ of growth thanks to the net-export effect [25].

Before moving on it is important to note that Russia and Ukraine are not simply neighbors of Belarus; they are its primary trade and investment partners. And they stay like this through the years, despite their economic recessions or recoveries. In 2019, the share of Belarusian exports of goods to Russian market of total was $43 \%$, and to Ukrainian market-11\%. The share of import from Russian of total in Belarus was $62 \%$, and from Ukraine- $5 \%$. The share of foreign direct investments from Russia of total to Belarus was $69 \%$, and from Ukraine-1\%.

There are two ways out of this trap for the Belarusian economy: reorientation toward the domestic market or diversifying into other foreign markets.

\section{Reorienting the economy from foreign markets to the domestic market}

While this may be a tempting solution, from January to March 2015 the share of Belarusian sales in the domestic retail market came to $68.9 \%$. For foodstuffs, that number was higher, at $81.6 \%$, and for non-foodstuffs, it was $50.9 \%$. The domestic market is simply not capable of completely replacing the volume of sales lost in foreign markets without increasing capacity.

Generally speaking, a reorientation toward domestic markets is generally part of a temporary import substitution strategy geared toward protecting from external competition.

The main argument in favor of import substitution is the need to temporarily shelter high-potential industries or companies from competition. However, in that case the sheltered industry has to use that opportunity to outpace the development of its foreign competitors (by cutting production costs faster, for example), coming out the other side having made up most of the ground separating 
them. Developing countries often point to examples where developed countries employed import substitution (the US, Germany, and Japan in the nineteenth and twentieth centuries) to, in their opinion, distance themselves from developing countries over the long term [26] .

Opponents of import substitution bring up the difficulty of deciding which prioritized industries should be protected [27]. Often the obvious choice for the government is looked at askance by private businesses that have invested elsewhere. At that point, the industry is prioritized by the administration and a temporary import substitution policy becomes permanent. Inflation is also a result of import substitution, as prices for both imported (thanks to new protective measures) and domestic goods rise. When that happens, national manufacturers often lower the prices they charge in foreign markets and compensate for the lost revenue by boosting them domestically.

\section{Diversification of foreign markets}

The focus Belarusian exports have fixed in the last few years on Russia and Ukraine has less to do with left-over post-Soviet relationships and more to do with their lack of competitiveness and lagging technological development. Belarus' concentration on its largest export Russian market has grown in recent years: from $37 \%$ of total exports in 2011 to $39 \%$ in 2015, and to $43 \%$ in 2019. Import is even more concentrated on Russia. During last decade, import from Russia to Belarus stayed more or less at the same level: 64\% of total imports in 2011, 62\% in 2015, and 62\% in 2019.

The problems Russia and Ukraine experienced in 2014-2015 have limited Belarus' export options. That would logically encourage a switch to other markets, but there Belarusian exports are less competitive. The situation is exacerbated by the lack of innovation in Belarusian exports. For example, the country's exporters (the Minsk Automobile Plant and the Minsk Tractor Works) do not have research centers abroad they can lean on for market analysis and forecasts, to learn about customer needs, and to tweak technology and manufacturing. Competitors like John Deer and MAN have R\&D centers in Germany (100 employees), France (120 employees), China, India, and the US. A systemic solution to the problem would be to move from a resource-based economic model to an investment-based model by attracting foreign direct investment, and from there creating a domestic culture of innovation.

The "conflict neighbor trap" often centers on the medium term with a likelihood of repeat occurrences in the long term, given that long periods of poor economic growth can lead to social unrest. The best way out of this trap for Belarus is to attract foreign direct investments in export companies focusing on highly competitive and high-tech markets.

\section{6 "The forceful pressure trap"}

This trap means that due to the state capitalism management system in Belarus, government and control agencies are deeply involved in business activities of business enterprises. Year by year, this administrative burden becomes forceful pressure on business and the barrier for economic growth. Being the part of the system, control agencies cannot stop the pressure by themselves. So they bring economy to almost complete stop as the enterprises try to avoid making mistakes in following norms and legislature and being punished. The state forceful pressure takes the forms of meetings, inspections, and court cases against business. 


\section{Meetings}

A survey of 800 directors of Belarusian firms run in 2013 by the Economy Research Institute of the Ministry of Economy found that $71 \%$ of those surveyed spend at least $20 \%$ of each week (one working day) on meetings with state agencies, the main topic of which, $91 \%$ say, is discussing their revenues, profits, and other indicators. With that in mind, private firms more and more prefer to avoid contact with the government in an effort to avoid that administrative pressure.

\section{Inspections}

According to the Association of Retail Networks, in 2014-2015, there has been an uptick in the number of inspections conducted by the Ministry of Trade. Traded goods themselves are also subject to inspection by the State Control Committee, several departments in the Ministry of Internal Affairs, the Ministry for Emergency Situations, the Ministry for Taxes and Levies, the Ministry of Labour and Social Protection, the Ministry of Natural Resources and Environmental Protection, the State Committee for Standardization, local authorities, and other monitoring and law enforcement agencies. Although the process is legally regulated, the administrative burden pushes operational costs higher for businesses.

\section{Court cases}

In 2015, some evident coercive pressure on the economy emerged in the form of an increased number of court cases dealing with administrative offenses in the economic sphere. According to the Supreme Court, the number of cases increased from 9792 in 2014 to 13,361 in 2015. Along with that, the major contributors to the coercive pressure on the national economy in 2014 and 2015 were the Ministry of Taxes and Duties—correspondingly 6804 and 9060 cases, the State Customs Committee-466 and 651 cases, the Ministry of Internal Affairs-446 and 415 cases, and the State Control Committee-357 and 398 cases.

In addition, there has been a rise in the percentage of cases resulting in administrative penalties to the overall number of cases filed in court: a total of $88 \%$ in 2014 and $90 \%$ in 2015, including cases related to the Ministry of Taxes and Duties-91 and 92\%, the State Control Committee-85 and 88\%, the State Customs Committee-47 and 73\%, and the Ministry of Internal Affairs-69 and 66\%. Only a few appeals were satisfied in whole or in part against the action or inaction of officials and verification of legality. Moreover, the number of appeals has been decreasing since 2013. A total of 102 decisions were challenged in court as appeals against actions of officials of the Ministry of Taxes and Duties in 2013; 12 claims were satisfied in whole or in part. In 2015, the corresponding figures were 78 and 6. Regarding the State Customs Committee, the numbers were 168 and 78 in 2013, and 112 and 6 in 2015.

A year-long comparison of the overall quantity of initiated criminal cases related to economic offenses shows a steady increase in the number: 2129 cases in 2012, 2639 in 2013, 2867 in 2014, and 3580 in 2015. The number of administrative cases related to economic offenses has also been growing: 111,421 cases in 2012, 121,052 in 2013, 121,371 in 2014, and 128,005 in 2015.

For Belarus, getting out of this trap means decentralizing state regulation of the economy as well as strengthening and promoting independence and material incentives for state institutions to bring in result-oriented professionals. Better information in addition to more openness and transparency are critical, as are keeping 
decision-making out of the hands of individuals, engendering trust, and building respect. Authority has to be delegated to ministries, departments, and sections in keeping with the principle that simpler problems can be solved farther down the food chain. Dividing up the regulatory and economic functions of state agencies needs to happen, putting ministries in charge of industries and more general areas without responsibility for the economy on the micro level.

The state would be wise to deprioritize the letter of the law when it comes to monitoring compliance with the rules governing business (something that is undoubtedly important in an institutional economy). As it sets up institutions and oversees the development of the economy, most important is for Belarus to ensure currency and financial stability by prioritizing tax- and currency-related crimes (though punishing them cannot be used as a means to other ends). Relaxing control, especially over small and medium business, would create space for them to experiment, try new approaches and methods, test new suppliers and clients, and breathe life into the economy. Once changes have been made to economic structures, control can be adapted to those new forms and fully reinstated.

\section{Public values behind state capitalism in Belarus}

State capitalism cannot function in Belarus without public support thanks to income equality and moderate income growth. In 1990, the inequality index (GINI index from 0 to 1 , with 1 signifying extreme inequality) in Belarus was 0.24 , in 2000 it was 0.23 , in 2010 it was 0.27 , and in 2018 it was 0.25 . That number looks even better when juxtaposed with those of other countries featuring high levels of state involvement in the economy. For example, in Russia in 1991, it was 0.26 before rising to 0.44 in 2018; in China, it was 0.33 in 1990 and 0.47 in 2018. While the average monthly salary in Belarus in the 1990s came to a few tens of dollars, by 2006 it had grown to 271, and in 2014, it reached a 25-year high of 595 dollars; in May 2020, it was 476 dollars.

Public support consists of the variety of values, and it is a double-edge sword how the values influence on the economy and the economy influences on the values in Belarus.

\subsection{Influence of values on the economy in state capitalism of Belarus}

Belarusian matrix of values' impact on the economy is complex, both random and orderly.

The randomness is expressed in doublethink, swaying between collectivism and individualism, emotionality and restraint, the past and the future, short- and long term, conservatism, and liberalism [28]. In the theory of behaviorism, the first decision is usually considered irrational and incorrect (the so-called "halo effect"), while the second one is rational and more accurate. In the case of Belarus, both decisions look irrational, and the Belarusian state capitalism itself is akin to a set of anomalies. A decision can be affected by the unpredictable specific context, case, mood, fatigue, hunger, time of day, previous meeting, another person's statement, personality, association with the surname of the person in question, or something else that cannot be foreseen. All these are situational factors of the value matrix. Because of constant reflection and adaptation, the national features of psyche and local behavioral practices replace the classical economic theory and world practices, playing the priority and effective role in the Belarusian state capitalism.

The orderly influence of the Belarusian matrix on the economy is reflected in the perceived influence of a range of cultural, economic, and other factors on the matrix itself and, thus, on the economy. Such factors are difficult to weigh and 
prioritize depending on their impact on the Belarusian economy. These are the "tectonic plates" of the Belarusian behavioral economics, which overlap and move with time. They form the overall information and cultural environment, in which decisions are made, the values, which are shared by the public and combine into the cultural matrix, the unifying factors, which nowadays make the Belarusian matrix Belarusian, distinguishing it from other societies.

The range of valuable factors that orderly influences on Belarusian state capitalism includes the following.

Memory of the war: according to a sociological survey of 2013, 89.6\% of Belarusians called the Great Patriotic War the main historical event for Belarusians [29]. The memories and fears of the war trigger the desire to seek protection from a strong leader and provide the basement for state capitalism. In 2010-2014, 58\% of Belarusians worry about the war involving in the country [30]. Belarus preserves the inert military mentality of the strong role of the state and paternalism. This leads to increased control over businesses, maintaining the traditionally high budgetary expenditures on poorly performing enterprises, accompanied by the decreasing incomes of the population.

Family orientation: it forms the dualism of collectivism and individualism. It narrows the circle of trust, range of partners, limits behavioral practices, and restrains social identity. In addition, such features as paternalism and orientation to the Soviet past are formed under the influence of Belarusian family orientation. During economic slowdown, family values have become stronger. In the period of economic growth in 1999-2009, from 78 to 81\% Belarusians considered their families as very important in life. In 2010-2014 when economic growth declined, $88 \%$ respondents gave that answer [30].

Language: Russian is the main spoken language, the language used for writing documents and the language of thought, while the Belarusian language is not so popular for many in the country. In 2010-2014, 83.3\% of Belarusians speak Russian at home, while only 6.5\% speak Belarusian [30]. Russian largely determines many Belarusian features, for example, the orientation to the Soviet past, hence the orientation to scale, to short-term planning and paternalism, as well as individualism in the form of isolation from the rest of the world. The use of the Russian language in the Belarusian economy predetermines the orientation of its foreign trade, investments, and tourism to Russian-speaking partners.

Sense of ownership: in Belarus, the collective memory, orientation to the Soviet past, orientation to scale, and paternalism, dull the sense of ownership. It affects the public's attitude to large state-owned enterprises as features of heritage and culture, which then constrains their privatization and restructuring. In general, the Belarusians sense of ownership is very polarized with no strong attitude toward government or private ownership [30].

Fears: in Belarus, phobias explain the roots of state capitalism. The fear of losing earnings, say because of their depreciation due to inflation, exceeds the willingness to earn more, which creates a greater propensity to save than to invest. The fear of losing a job with a change of owner, following the example of Russia in the 1990s, creates a cautious attitude toward privatization. In 2010-2014, 56\% of Belarusians were afraid of losing their jobs [30]. The fear of the future and disappointment in the present forms the orientation to the past in the search for answers. The fear of punishment, both inherited and learned, serves as a habitual motivation in the paternalistic regime.

\subsection{Influence of the economic anemia/growth on the public values in Belarus}

Recent economic anemia in Belarus has transformed public values. It no longer raises the question how the state capitalism restores the high level of economic 
growth in Belarus. Now it faces new dilemma if the state capitalism is capable of doing that. If public values behind economic anemia have changed dramatically, then it would mean that the issue of state capitalism efficiency has moved from economic to sociological and political fields of science.

Belarusian's public values could be compared in different time periods of economic growth and economic anemia (Table 2). There is no strong evidence that people are looking for solutions of economic problems in the ownership of business. More likely they see other reasons of economic anemia in Belarus rather than private vs. state ownership of business, as the two are interconnected in the country. Moreover, Belarusians prefer the government to take more responsibility during hard times and less the people themselves. When economic growth is high, people also have high confidence in the government. But when economic growth is low, the public confidence in the government is decreasing. So it is easy to see that economic growth fluctuations in Belarus are reflected in the public opinion on the responsibility of the government and its state capitalism.

Some more observations of Belarusians public values behind economic anemia could be added that influence on the business climate and the health of society. So important for economic growth trust is decreasing during economic slowdown. In 2010-2014, the answer "most people can be trusted" has been decreased from 41 to $33 \%$, and the answer "need to be very careful" has been

\begin{tabular}{|c|c|c|c|c|c|}
\hline & & $\begin{array}{c}1994 \\
1998\end{array}$ & $\begin{array}{c}1999- \\
2004\end{array}$ & $\begin{array}{l}2005- \\
2009\end{array}$ & $\begin{array}{c}2010- \\
2014\end{array}$ \\
\hline GDP growth, average $\%$ & & 0.1 & 5.18 & 7.68 & 3.52 \\
\hline \multirow[t]{3}{*}{$\begin{array}{l}\text { Private vs. state ownership } \\
\text { of business }\end{array}$} & $\begin{array}{l}\text { Private ownership } \\
\text { should be increased }\end{array}$ & 8 & 9 & 8 & 11 \\
\hline & Medium & 22 & 23 & 26 & 21 \\
\hline & $\begin{array}{l}\text { Government } \\
\text { ownership should be } \\
\text { increased }\end{array}$ & 18 & 8 & 4 & 6 \\
\hline \multirow[t]{3}{*}{$\begin{array}{l}\text { Responsibility: } \\
\text { government vs. people }\end{array}$} & $\begin{array}{l}\text { People should take } \\
\text { more responsibility }\end{array}$ & 5 & 12 & 12 & 4 \\
\hline & Medium & 5 & 19 & 19 & 5 \\
\hline & $\begin{array}{l}\text { Government } \\
\text { should take more } \\
\text { responsibility }\end{array}$ & 29 & 16 & 6 & 23 \\
\hline \multirow[t]{2}{*}{$\begin{array}{l}\text { Confidence: the } \\
\text { government }\end{array}$} & A great deal, quite a lot & 47 & $\begin{array}{c}\text { Not } \\
\text { available }\end{array}$ & 60 & 56 \\
\hline & $\begin{array}{l}\text { Not very much, not } \\
\text { at all }\end{array}$ & 46 & $\begin{array}{c}\text { Not } \\
\text { available }\end{array}$ & 30 & 43 \\
\hline \multirow{2}{*}{$\begin{array}{l}\text { Political system: having a } \\
\text { strong leader }\end{array}$} & Very good, fairly good & 49 & 34 & 62 & 47 \\
\hline & Bad, very bad & 39 & 50 & 25 & 52 \\
\hline \multirow{2}{*}{$\begin{array}{l}\text { Political system: having } \\
\text { experts make decision }\end{array}$} & Very good, fairly good & 44 & 63 & 52 & 56 \\
\hline & Bad, very bad & 34 & 17 & 30 & 42 \\
\hline \multirow{2}{*}{$\begin{array}{l}\text { Political system: having } \\
\text { the army rule }\end{array}$} & Very good, fairly good & 12 & 16 & 13 & 9 \\
\hline & Bad, very bad & 74 & 69 & 72 & 91 \\
\hline \multirow{2}{*}{$\begin{array}{l}\text { Political system: having } \\
\text { democracy }\end{array}$} & Very good, fairly good & 66 & 67 & 72 & 85 \\
\hline & Bad, very bad & 16 & 8 & 9 & 15 \\
\hline
\end{tabular}

Table 2.

Public values and economic growth in Belarus, \% of total respondents [30]. 
increased from 50 to $60 \%$. The values of such qualities like tolerance and respect for other people has become less important during economic anemia falling from 64 to $61 \%$ in $2010-2014$ [30].

Economic anemia in state capitalism transforms public attitude toward political system (Table 2). In the case of Belarus, the popularity of strong leader political system has been decreasing during low economic growth. People increase their good attitude to the experts making decision political system, but not so much. When Belarusian's state capitalism tries to use force pressure to solve economic problems, it also makes political system ruled by army absolutely unpopular. Finally, the main transformation of public values behind economic anemia is the strong rise of popularity toward democratic political system. It brings the doubts about the future of the current mode of state capitalism in Belarus without reforms.

\section{Conclusions}

Belarusian state capitalism is the hybrid regime of transition economy. Currently it covers only half of GDP, half of employment, and around $60 \%$ of banking assets and banking capital. It is based on the high level of public expenditures to GDP, medium level of tax burden, and wide range of state-owned enterprises. There are plenty of underdeveloped financial instruments in Belarus that could support its state capitalism nowadays, like banking system, financial market, monetization of GDP, and foreign direct investments.

In 1996-2010, state capitalism boosted high economic growth in Belarus on the level of average $7 \%$ per year. But it was also accompanied by high inflation, current account deficit, and currency crises. In 2011-2019, Belarus faced some traps on the way of its economic growth: "debt trap," "middle-income trap," "social burden trap," "resource curse trap," "conflict neighbors trap," and "forceful pressure trap." They all lead to the economic anemia in the country on the level of a little more than $1 \%$ per year during last decade.

Belarusian state capitalism exists because of public support, based on economic equality, and the rise of incomes. During economic growth such public values like the memory of the war, family orientation, language, sense of ownership, and various phobias supported state capitalism in Belarus. But, during economic anemia, the fall of incomes, the public attitude to political system has changed dramatically and brought state capitalism existence to new crossroads.

\section{Author details}

Kiryl Rudy

Belarus State Economic University, Professor at the Department of World Economy, Minsk, The Republic of Belarus

*Address all correspondence to: kvrudy@gmail.com

IntechOpen

(C) 2020 The Author(s). Licensee IntechOpen. This chapter is distributed under the terms of the Creative Commons Attribution License (http://creativecommons.org/licenses/ by/3.0), which permits unrestricted use, distribution, and reproduction in any medium, provided the original work is properly cited. (cc) BY 


\section{References}

[1] Aslund A. Russia's Crony Capitalism: The Path from Market Economy to Kleptocracy. London: Yale University Press; 2019. p. 336. DOI: 10.1002/9780470974704

[2] Aslund A, Djankov S, editors. The Great Rebirth. Lessons from the Victory of Capitalism over Communism. New York: Peterson Institute for International Economics; 2014. p. 320. DOI: $10.1002 / 9780470974704$

[3] Magnus G. Red Flags. Why Xi’s China is in Jeopardy. London: Yale University Press; 2019. p. 264. DOI: 10.1002/9780470974704

[4] Kurlantzick J. State Capitalism: How the Return of Statism Is Transforming the World. Oxford: Oxford University Press; 2016. p. 296. DOI: 10.1002/9780470974704

[5] Rudy K. Financial Diet: State Capitalism Reforms (the Path for Belarus). Minsk: UNDP; 2016. p. 178. DOI: $10.1002 / 9780470974704$

[6] Ministry of Taxes and Levies of Belarus [Internet]. 2020. Available from: http://www.nalog.gov.by [Accessed: 28 June 2020]

[7] Piketty T. Capital in the Twenty-First Century. Cambridge: Belknap Press; 2014. p. 685. DOI: 10.1002/9780470974704

[8] Assets of Financial Sector Institutions in China Total \$45.12 Trillion at the end of 2019 [Internet]. 2020. Available from: http://www.chinabankingnews.com [Accessed: 21 June 2020]

[9] Wang Y. Beijing at the Helm. Jersey City: Forbes Asia; 2017; November. pp. 12-13. DOI: 10.1016/ s0014-5793(01)03293-8

[10] The National Statistical Committee of the Republic of Belarus [Internet].
2020. Available from: http://www. belstat.gov.by [Accessed: 21 June 2020]

[11] The National Bank of the Republic of Belarus. Banking Sector, as of April 1, 2020 [Internet]. 2020. Available from: http://www.nbrb.by [Accessed: 21 June 2020]

[12] IMF Country Report No. 10/16. Republic of Belarus: Selected Issues. IMF; 2010. p. 26

[13] Kruk D, Bornukova K. Belarusian Economic Growth Decomposition/ BEROC Working Paper Series. Working Paper No. 24; 2014. p. 39

[14] Reinhart C, Rogoff K. This Time Is Different: Eight Centuries of Financial Folly. Princeton: Career Press; 2012. p. 472. DOI: $10.1002 / 9780470974704$

[15] Gill I, Kharas H. An East Asian Renaissance: Ideas for Economic Growth. Washington D.C.: The World Bank; 2007. p. 366. DOI: 10.1002/9780470974704

[16] The World Bank in Middle Income Countries [Internet]. 2007. Available from: http://www.worldbank.org/en/ country/mic/overview\#2 [Accessed: 20 April 2018]

[17] Escaping the Middle Income Trap Global Economic Symposium [Internet]. 2010. Available from: http:// www.global-economic-symposium.org [Accessed: 20 April 2018]

[18] Spence M. The Next Convergence. The Future of Economic Growth in a Multispeed World. New York: Farrar, Straus and Giroux; 2011. p. 320. DOI: 10.1002/9780470974704

[19] Agenor P. Avoiding Middle-Income Growth Traps. World Bank Working Paper. № 98; 2012. p. 7 
[20] Rudy K, Bobrovich V, Lashuk I, Urban D. "Middle-income trap": Interdisciplinary evaluation of the way out for Belarus. Belorusskiy Economicheskiy Journal. 2018;3:4-18. DOI: 10.1016/s0014-5793(01)03293-8

[21] Shimov V. Innovative Development of the Belarusian Economy: Drivers and National Priorities. Minsk: Belarusian State Economic University; 2014. p. 199. DOI: $10.1002 / 9780470974704$

[22] Sharygina Y, Sivaev S.

A Comparative Analysis of Utility Available for Citizens of the Russian Federation and Other Countries. Vol. 6. Moscow: Voprosy Economiki; 2015. pp. 63-105. DOI: $10.1016 /$ s0014-5793(01)03293-8

[23] Gaidar Y. Collapse of an Empire: Lessons for Modern Russia. Political Encyclopedia. Washington D.C.:

Brooking Institution Press; 2006. p. 592. DOI: $10.1002 / 9780470974704$

[24] Collier P. The Bottom Billion: Why the Poorest Countries Are Failing and What Can Be Done about it. Oxford: Oxford University Press; 2007. p. 205. DOI: $10.1002 / 9780470974704$

[25] Vinhas de Souza L. The CIS and Russia-Ukraine stresses. Moody's investors service. In: Presentation at Global Context, Local Solutions: Belarus; Private Sector Potential. 2014. p. 29

[26] Reinert E. How Rich Countries Got Rich and Why Poor Countries Stay Poor. London: Constable \& Robinson; 2008. p. 400 . DOI: $10.1002 / 9780470974704$

[27] Wolf M. Why Globalization Works. London: Yale Nota Bene; 2005. p. 416. DOI: $10.1002 / 9780470974704$

[28] Rudy K. "Because We Decided So": Behavioral Economics of Belarus. Brest: UNDP; 2018. p. 184. DOI: 10.1002/9780470974704
[29] Lashuk I. Reproduction of Historical Memory in the Great Patriotic War in Public Opinion of Belarusians and Russians. Minsk: Institute of Sociology of National Academy of Science; 2016. p. 35

[30] World Values Survey Database [Internet]. 2020. Available from: http://www.worldvaluessurvey.org/ WVSOnline.jsp [Accessed: 29 June 2020] 



\title{
Crisis Management and the Public Sector: Key Trends and Perspectives
}

\author{
Christos Lemonakis and Antonios Zairis
}

\begin{abstract}
A crisis is a situation approaching a dangerous phase, which requires urgent intervention to avoid harmful effects on the body of an organization in order to return to normal situation. It is a decisive and critical time for the organization, where the wrong decision can even cost its viability. This situation can shape political, legal, economic, and governmental impact on its activities. From different definitions of crisis, we seek to underscore key elements of a crisis that may threat a public organization and, also, to highlight both the elements of management responsiveness resulting in the loss of control in the organization, regarding the short time demand for decision-making. The key purpose of this chapter is to illustrate the basis available in the international literature, upon which public risk mechanisms can be reviewed and chosen in public sector organizations under the scope of their applicability.
\end{abstract}

Keywords: public sector management, crisis management, organizations' management

\section{Introduction}

In the everyday life, the concept of crisis can encompass the whole range of activities and relationships, at an individual, social, and political level. But its interpretation varies, depending on the perspective of the crisis, regarding personality, experience, and professional level. In the context of organizations and systems, the crisis and its response have become particularly important nowadays, due to the unforeseen forms in which it can occur, the degree of damage it can cause to their structures and operations, the dimensions that it can realize in a short time, the modern environment of globalization, and the fast dissemination of information through enhanced communication networks. The crisis may manifest itself on the horizon as a result of a wrong decision, or it may occur without warning, anywhere, anytime. It can affect all sectors of society, businesses, government, and nongovernmental organizations. In order to safeguard the viability of organisms in critical situations, there is a need for constant monitoring and analysis and an academically sound approach to documentation of actions needed.

Therefore, managing the crisis by public bodies and governments is a prerequisite for their smooth operation and survival. According to Porter's theory of resources and capabilities, the main mechanism for the survival of the organisms in the environment in which they operate is the dimension of competitive advantage, 


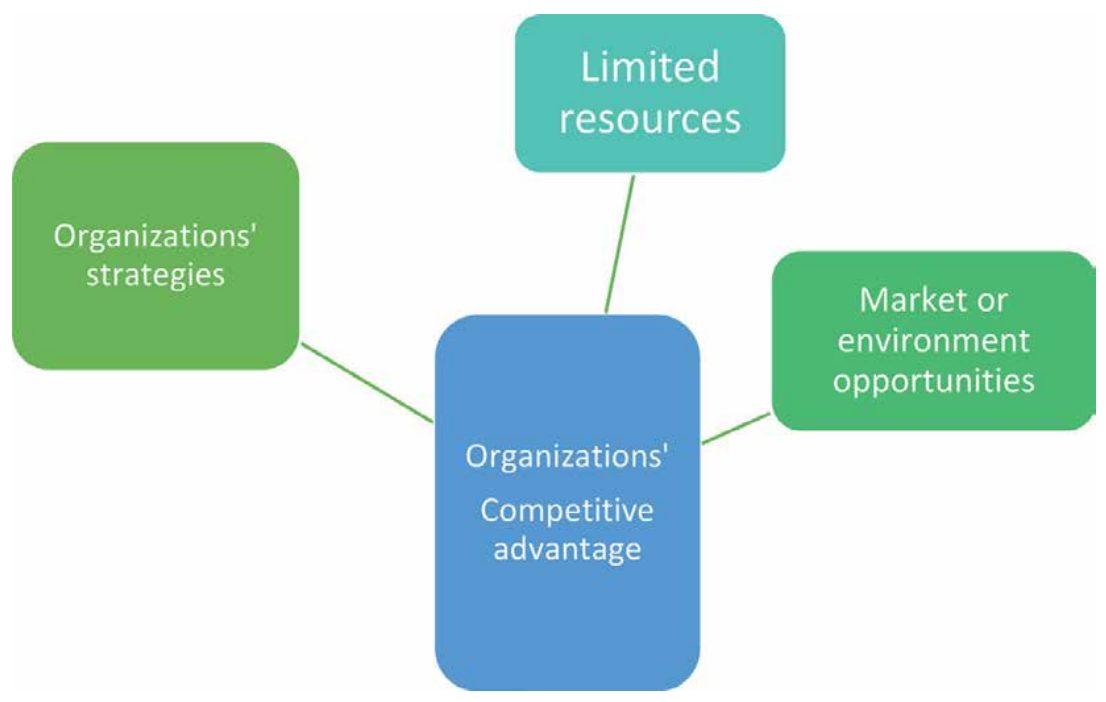

Figure 1.

Crisis in the real-world environment.

in which organizations must face threats and seize opportunities, given their adopted strategies, occasional choices, and actions they decided to take, regarding the limited resources available (see also Figure 1).

And while organizations are taking precautionary measures to deal with exceptional critical events, the degree of achievement of the intended results remains low.

But how can we define crisis? According to the Greek language [1], the term crisis refers to the mental process of the human being to reason deeply and to arrive at sensible conclusions and judgments, by choice, but also to disturb the smooth course of a process, malfunctioning or improperly challenging structures, values, and institutions. In Chinese, judgment is pronounced gei-zi and is a compound word that denotes "danger" and "opportunity" at the same time. In the context of organizations, a crisis is a low-probability event with major implications, which threatens the viability of an organization and is characterized by unclear causes and effects and ways of finding a solution as well as the belief that decisions must be made within a short time. According to Robert [2], the crisis is an incident that threatens to be harming the people's safety, the environment, the reputation of an organization, and its stakeholders involved.

\section{Crisis management and the public sector}

According to [3], a definition of crisis management is the "careful study and anticipation of the risks that a business/organization may pose to reduce uncertainty and take all necessary measures"-actions, processes, and processes before, during, and after the crisis to protect people, the environment, employees and the financial position of the business." A public body is in crisis when its institutional status is challenged as well as basic structures, principles, and values are also threatened. For the public administration, the crisis may concern the whole or a large part of the population. Although crises are unpredictable, they are not unexpected and can affect all areas of society and are caused by many different causes. The authors of [4] believe that "the crisis relates to situations characterized by severe threat, uncertainty and a sense of urgency." Crises also reach a critical point where change, for better or worse, is inevitable and the experience can be proven beneficial to 
people and organizations [5]. Also, in [6], the crisis is defined as: "a big, sudden event, which is likely to have negative effects. The fact and its consequences can seriously damage an organization and its employees, as well as its products and services, its financial status and reputation." This approach reinforces the need to manage the organization's communication and image.

A crisis is a situation that is approaching a "dangerous" phase, which requires urgent intervention to avoid harmful and potentially harmful effects on the structure of an organization and return to normality. It is a decisive and critical time for the organization, where the wrong decision can, as mentioned above, even cost its viability. According to the Institute for Crisis Management [7], the crisis is a situation of significant business (see also "operations") disintegration, which has resulted in negative reactions from all stakeholders, probably extensive media coverage, and public scrutiny. This situation may have a political, legal, economic, and governmental impact on its activities.

In the context of the crisis definition, we can conclude that the common elements contained in a crisis are the potential threat, which may be posed to all resources of an organization, the state of absolute surprise resulting in loss of control, and finally the short time remaining for decision-making. From the definitions above, we can easily understand the importance of the public sector crisis management, as unexpected events can affect the public and therefore the citizens of this sector, through the central government. A crisis may consist of four distinct stages, i.e., (a) the pre-crisis phase, (b) the acute phase of the crisis, (c) the time course of the crisis, and finally $(\mathrm{d})$ the crisis resolution stage.

According to [8], every crisis, regardless of its form and the organization in which it is created, has the following characteristics: (a) It escalates in tension, (b) it causes a high sense of insecurity and danger, and (c) those involved are overwhelmed by stress, affecting the usual operability of the organization, while it changes the operational structure, and affecting also the "image" of the organization or of the government itself, arousing the interest of the competent bodies and especially the media to get involved in the situation. The increased demand for information that needs to be monitored by a specific group of the organization's staff may cause moral effects, not only in terms of "image" but also in material terms, which potentially may encompass to the power of the organization in real life, or even to the profile of the body, while causing a malfunction in its operational activity.

Crises are unforeseen events that have the potential to produce undesirable effects [9]. Also, they described crisis as a product of a risk or opportunity arising from internal or external issues that can affect an organization on a massive scale. In [10] they describe crises as a result of human intervention rather than natural disasters in order to separate the scope of crisis management from that of risk and emergency management. The participants are surprised and have very little time to make difficult decisions in an atmosphere full of tension and volatility. A crisis is a large-scale unpredictable event that threatens to hurt an organization and its stakeholders. An incorrect management decision can be a cause for serious operational risk.

Each crisis, regardless of the category to which it belongs, goes through different phases depending on the time of occurrence, and each phase affects the body differently (see also Figure 2).

The phases are (a) pre-crisis (condition or precursor), (b) acute phase (manifestation-peak crisis), (c) response (impact) phase, and (d) recovery or resolution phase (resolution-normalization) [11].

Each crisis is characterized by the factors that cause it. The main categories of critical situations are four depending on the causes of the crisis, which may come from internal or external factors of the organization and may be characterized as "technical-economic" or "human-organizational-social” factors (see also Table 1). 


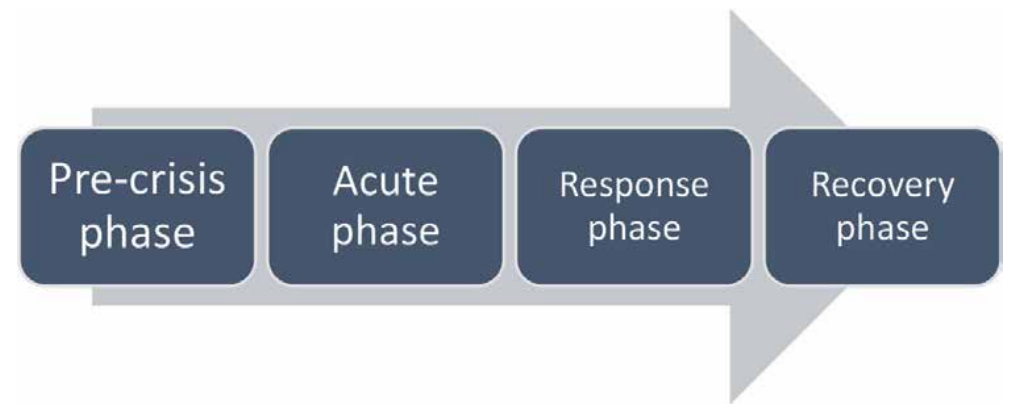

Figure 2.

Key phases of a crisis event.

\begin{tabular}{ll}
\hline Technical-economic factors & Human-organizational-social factors \\
\hline Internal factors & \\
\hline - Incomplete information & - Inability to adapt to changes \\
- Collapse of electronic systems & - Organization's communication crash \\
- Accidents due to defective products & ・ Intentional damage (i.e., a product of sabotage from \\
- Industrial accidents & internal factors) \\
& Occupational issues \\
\hline External factors & - Sabotage by external factors \\
\hline - Environmental disaster & Terrorist actions \\
- Sabotage by external factors & \\
- Natural disasters & \\
- Terrorism actions & \\
- Mergers and acquisitions & \\
\hline - Scams & \\
\hline Source: Mitroff [12]. &
\end{tabular}

Table 1.

Separation of crises.

The "technical-economic factors" mainly consist of natural disasters, earthquakes, floods, fires, hurricanes, H1N1 virus, mad cow disease, etc., while the "human-organizational-social" factors may include, among others, political and/or economic crises or even political instability in countries.

They may also include characteristic cases regarding information leakage and loss of human lives.

In the case of the "technical-financial factors," issues are raised from defective products that drive companies to withdraw them from the market, defective machinery that can be hazardous to human use or may result in injuries to personnel or other stakeholders (i.e., customers, partners), or in extreme cases even in an accident.

\section{Definition of the "reorganization" or "redesign" factor}

The determinant effect of the "reorganization" factor is the response of public sector organizations to critical situations. This section defines the factor 
"reorganization," which illustrates the need for the factor, its contribution to the operational context of public administration through a bibliographic review, and a case study of the reorganization and the crisis of public sector organizations.

The "business process reengineering" ("BPR"), to the service of the reorganization or redesign [13], corresponds to a radical and "fundamental" redesign of business processes, so that substantial changes can be made to key areas that determine operational performance, such as production cost (better "cost of development"), productivity, service and product costs (better "delivery cost"), quality provided, customer service, and speed. The concept of redesign was originally designed for private sector businesses and then extended to bureaucratic processes of public administration. The term fundamental redesign means that the body/organization decides to completely abolish the process it is currently applying and is intending to accept another, new process. Radical redesign also refers to fundamentally changing all processes, while redesigning is about applying a new business process rather than improving or modifying an existing one. Spectacular improvements relate to the product of the business and not to the marginal improvements that can be made by improving the management of the processes applied. According to the above, in case that a company seeks to modernize itself by changing its processes, it should ask itself why it applies these processes and why it does so.

In [14], the authors also argue that reorganization can be defined as the analysis and planning of in-company and inter-company workflows and processes. According to the same researchers [15], the concept of business reorganization is an integral part of a larger "idea" and therefore introduces the term business innovation process which implies the creation of a strategic vision and the engagement of human resources, technology, and other critical resources in planning and implementing change.

In [11] they argue that the concept of reorganization is fundamentally related to the re-examination and redesign of a company's business processes and organizational structure, with the aim of achieving clear improvement in key areas such as quality, productivity, customer satisfaction, and the time it takes for a product to reach the market.

In [14] it reports that BPR is the analysis and planning from the beginning of intra-business workflows and processes.

The term "process innovation" encompasses the consideration of a broader strategy, the design of the process, and its application to all complex technological and organizational structures [16]. Other authors focus on reviewing, restructuring, and redesigning the business structure, processes, working methods, management systems, and external relationships through which value is created and disseminated. For [17], BPR involves the simultaneous redesign of business processes and their support systems in order to achieve a radical improvement in time, cost, quality, and customer perception of the company's products/services.

In summary, a business restructuring can be regarded as a critical analysis, reassessment, and radical redesign of existing business processes to achieve significant improvements in performance metrics, from the perspective of relocating and changing the overall business strategy.

\section{Factors of "reorganization"}

Through reorganization, the company sets goals, such as improving productivity, in order to increase product output, rationalizing the management of production costs and resources, making the most of the available human resources, optimizing 
financial performance and cash flow, and improving existing processes and operations. The strategic goal of reorganization is to increase the value of the business.

Looking at the business from a financial point of view, internal considerations can "force" a firm to restructure itself, such as the dire prospects of liquidity performance indicators, thus requiring active strategies in the structural characteristics of businesses. In addition, the inefficient functioning of internal structures is based on human resources and processes, which act as a barrier to critical administrative decision-making.

Another factor contributing to the reorganization is the repositioning of the overall business strategy implemented by changing the goals and direction of the organization, activities, redeployment, or layout of resources, adapting to the environment, and responding to market needs and to the satisfaction of shareholders and stakeholders.

Thus, the reasons for deciding whether or not to restructure may be either in the internal operating area of the business or in the external environment (micromacro environment). With the use of SWOT [18] analysis of a business, where the strengths and weaknesses of the business are identified and compared with opportunities, and threats to the external environment are avoided, an organization running under a specific framework can be reorganized. The redesign procedural framework requires careful study and structured procedures so that the actions taken will enable the business or organization to achieve the desired result for the target product or customer. Criteria for implementing these processes are the company's new strategy and its goal of providing customer-oriented services. The other areas of redesign relate to more efficient operation of the production process, which adds a comparative advantage to the finished product. Elements of a restructuring or redesign program are the benchmarking of a firm's performance based on measurable parameters of strategic importance with performance indicators over other competing companies operating in the same area. Another element of the reorganization of organizations is the upgrading of human resources, which need to be equipped with appropriate tools for more efficient work and better and complete information. In this case, information systems are of particular importance throughout the reorganization process, as they dramatically change the efficiency and effectiveness of the business.

In general, we argue that key steps to be taken in business reorganization are as follow: (i) to reorder strategic goals, (ii) to create a leadership team to execute the strategic plan, (iii) to study and adopt best business practices, (iv) to develop technology networks, (v) to identify opportunities, potential problems, and threats, (vi) to use appropriate performance indicators, (vii) to implement a modern financial management model, and (viii) to implement an effective measurement results' system.

In general, the process of implementing the restructuring plan can be divided into four main stages (see also Figure 3):

a. Assessing the current state of the business such as products, various financial data, organization chart, competition, customers, suppliers, and banks

b.Identifying reorganization goals and preparing the work plan by defining the reorganization goal; planning the action plan; discussing, accepting, and adopting the plan from executives and employees; communicating the vision; and preparing executives and staff for the change process

c. Implementation of the work plan with precise action schedules, identifying important milestones for the project, accurate task allocation, project monitoring process, and correcting any divergences from expected results 


\section{Assessing the current state of the business}

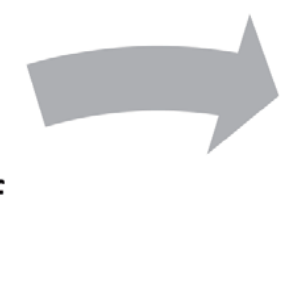

\section{Identifying \\ reorganization \\ goals and \\ preparing the \\ work plan}

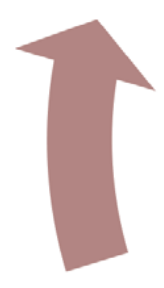

Evaluating results
Implementation of the work plan

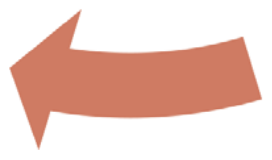

Figure 3.

Steps of a public organization's restructuring plan.

d.Evaluating results by establishing a reliable benchmarking mechanism, before and after a reorganization, and recording results and experiences for future use by the company

\section{Necessity of redesign in public organizations}

The necessity of having the factor of redesign in critical situations in public organizations arises from the work of a number of researchers in the field of "public administration."

According to $[6,19]$, restructuring of public administration refers to reforming its operational processes to achieve its strategic goals, while reforming its organizational structure and institutional framework to support new processes. The reasons for implementing redesign programs in public administration are summarized as follows [20, 21]:

I. Public sector lags the private sector: The public sector has not been reformed at the same time as the private sector, still causing deficits and budget crises.

II. The crisis of legitimacy of the modern state: This phenomenon stems from the inability of the modern state to effectively tackle rather complicated social phenomena, due to lack of transparency in public administration mechanisms and from the increased criticism originated from the people toward the political system. The consequence is the depreciation of the authority of the state and its establishment toward its constituencies, the citizens, being considered as an anachronistic and declining institution. 
III. The need to limit public administration costs imposed by fiscal consolidation programs: The reduction of expenditure is not accompanied by a simultaneous reduction of administrative responsibilities. On the contrary, it is necessary to increase the effectiveness of public organizations since they have to achieve the same results with fewer resources, with minimal results.

The benefits of redesigning public administration can be summarized as follows [22-24]:

a. Improving the efficiency of public procedures by reducing the administrative costs of executing them.

b.Improving the quality of services provided to citizens.

c. Increasing public satisfaction with public administration.

d.The modernization of the institutional framework and organizational structure of public administration to support its new way of functioning. This reduces bureaucracy and simplifies administrative procedures.

e. Outcome management through indicators and objectives of different categories. This, in turn, leads to more efficient public budgets, based on efficiency and more effective control of public spending.

f. Increase the transparency of the state mechanism by keeping and publishing indicators and results. The consequence is the development of a stable business environment conducive to investment and growth.

g. Increasing public interest in public procedures. A well-organized public administration that operates efficiently and with full transparency increases citizens' interest in public participation and strengthens their faith in the political system.

According to Decenzo and Robbins [25], redesigning public administration is a particularly difficult task due to the particular characteristics that differentiate public from private organizations.

Redesign programs should be tailored to the specific characteristics of the public sector and include the following actions [12, 26, 27]: defining a vision and a strategy for the organization. Most public agencies lack a clear strategy and focus. Without targeting it is impossible to design redesign programs.

IV. Detailed description of the procedures performed by the public administration: Redesigning a process requires defining it in detail: its execution steps, its inputs, and its outputs. Great many public agencies do not have a documented description of the procedures that follow, which makes it quite difficult to improve the process through performance indicators.

i. Measuring public satisfaction with public services

Customers' satisfaction with the outcome of a process and suggestions for improving it are one of the key parameters of process redesign in the private sector. On the contrary, in the public sector this factor is not considered at all. 
ii. Study of the legislation that defines the operational process

Public sector procedures are executed on the basis of a strict legislative framework. During the redesign process, the relevant framework should be studied in order to identify the constraints in the redesign process.

iii. Examine the transparency obligations of the public sector

The law is obliged to keep a large number of data on all its acts and decisions, so that their legality can be subsequently checked. This introduces restrictions on redesign, since activities that add no value to the end result should also be foreseen.

iv. Contribution of the operational managerial framework in public sector organizations

Businesses today, both in the private and public sectors, are called upon to operate and adapt in a complex new environment, characterized by the globalization of the age, complexity, uncertainty, competitiveness, and modern technology. As a result, there is pressure on businesses and organizations as well as public authorities to adapt and respond promptly to change, rational use of resources, high value for money, and excellent customer/customer service.

In other words, in order to succeed in any business venture, special attention should be given to planning or restructuring the organization of the business in order to achieve all of the above. Traditional forms of business organization, in our time, are no longer able to cope with the pressures and demands that are created.

This weakness has led to the need for redesign—restructuring of business processes-processes, so that the new structure of any organization/business is flexible, readily adaptable to new conditions, simple, fast, and horizontal, in order to meet the objective of each business.

v. The effectiveness

New business processes should be governed by:

1. Integrated and horizontal processes

2. Define flexible and simple internal procedures

3. Horizontal structures that touch the whole organism

4. Aim for the correct customer service

5. Employees to participate, responsibly

6. Having a single responsibility center

The methodology for implementing the restructuring of the company's internal operations is based on the diagnosis, thematic problematic processes, and then the planning and implementation of new ones, based on the needs and objectives of each business organization. 


\section{Conclusions}

The redesign of the organization of the business brings about wider organizational and administrative changes, which are necessary for its proper and effective functioning. The most important changes are: operational structures are becoming horizontal, that is, we are replacing the classic operating segments with project teams that deal with a process from start to finish. Job descriptions become more interesting and less specialized, with no unnecessary duplication of work, with a greater variety of jobs, and with more freedom of initiative. Employees' values and beliefs are changing to support new internal processes. The roles of supervisors are transformed from supervisors to bureaucrats to managers to mentors. Performance indicators and remuneration focus on the successful outcome and achievement of the corporate goals that are set. From the above it becomes clear that the effective operation of any business goes through the process of redesigning or restructuring internal processes. It is our view that the business in question should be evaluated in relation to its internal processes, at regular intervals, by an external partner, in order to ensure objectivity.

In this way, the organization will be properly organized to achieve its goals and to gain comparatively competitive advantages over the market. Finally, it should be noted that the process of redesigning the internal processes of the company concerned is de facto carried out at the design and implementation stage of the ISO 9001 [28] quality management standard, as ensuring standard internal procedures ensure measurable, correct, and orderly operation of the business.

\section{Author details}

Christos Lemonakis ${ }^{1 *}$ and Antonios Zairis ${ }^{2,3}$

1 Management Science and Technology Department, Hellenic Mediterranean University, Crete, Greece

2 Neapolis University, Pafos, Cyprus

3 The Hellenic Retail Business Association (SELPE), Greece

*Address all correspondence to: lemonakis@hmu.gr

IntechOpen

(C) 2020 The Author(s). Licensee IntechOpen. This chapter is distributed under the terms of the Creative Commons Attribution License (http://creativecommons.org/licenses/ by/3.0), which permits unrestricted use, distribution, and reproduction in any medium, provided the original work is properly cited. (cc) BY 


\section{References}

[1] The word form "crisis" is nearly identical to the Greek word "krisis" from which it was borrowed into Latin, then into French, and finding its way eventually to the English tongue. Available from: https://pdfs. semanticscholar.org/e22d/3201b60d 1f9d7b2f38126a56751eb9cca98c.pdf. [Accessed: 10 September 2019]

[2] Biel R. The new imperialism: crisis and contradictions in northsouth Relations. Zed Titles on the Political Economy of Capitalism. Zed Books. https://books.google.gr/ books?id=u1C3AAAAIAAJ

[3] Glaeser D. Crisis management in the tourism industry. Burlington, MA: Butterworth-Heinemann, Oxford; 2003

[4] Rosenthal U, Pijnenburg B. Crisis Management and Decision Making: Simulation Oriented Scenarios. Book; 1991. ISBN 978-94-011-3398-2

[5] Prideaux B, Laws E, et al. Events in Indonesia: Exploring the limits to formal tourism trends forecasting methods in complex crisis situations. Tourism Management. 2003;24(4):475-487

[6] Barton L. Crisis Management: Master the Skills to Prevent Disasters. Boston, Mass: Harvard Business School Press; 2004

[7] ICM Annual Crisis Report Global News Coverage Of Business Crises In 2016. 2017. Source: http://www. crisiscommunications.com.au/ wp-content/uploads/2017/05/ICMAnnual-Crisis-Report-for-2016_IssuedApril-3_2017.ov_.pdf

[8] Ahmed M. The Principles and Practice of Crisis Management: The Case of Brent Spar. UK: Palgrave Macmillan; 2006. ISBN 978-0-230-62737-6
[9] Brønn PS, Olson EL. Mapping the strategic thinking of public relations managers in a crisis situation: An illustrative example using conjoint analysis. Public Relations Review. 1999;25(3):351-368

[10] Mitroff II, Harrington LK, Gai E. Thinking about the unthinkable. Across the Board. 1996;33:44-48

[11] Darling J, Hannu O, Raimo N. Crisis management in international business: A case situation in decision making concerning trade with Russia. The Finnish Journal of Business Economic. 1996;4:12-25

[12] Mitroff II, Alpaslan CM, Green S. Crises as ill-structured messes: Philosophical issues of crisis management. International Studies Review. 2004;6:175-182

[13] HammerM, ChampyJ. Reengineering the Corporation. New York: Haper Collins; 1993

[14] Davenport TH, Short JE. The new industrial engineering: Information technology and business process redesign. Sloan Management Review. 1990;31(4):11-27

[15] Mathews JA. Interfirm competitive dynamics within an Industrial Market System. Industry and Innovation. 2001a;8(1):79-107

[16] De Bruijn H. Managing Performance in the Public Sector. London: Routledge; 2002

[17] Daniel PP, John SC. Successful Reengineering. New York: Van Nostrand Reinhold; 1994

[18] SWOT. Analysis (i.e. strengths, weaknesses, opportunities and threats) sets a framework of organizing pros and cons characteristics. Available 
from: https://www.businessballs.com/ strategy-innovation/swot-analysis/. [Accessed: 15 November 2019]

[19] Barton L. Crisis in Organizations: Managing and Communicating in the Heat of Chaos. Cincinnati, OH: SouthWestern Pub; 1993

[20] Bates RA, Holton EF. Computerized performance monitoring: A review of human resource issues. Human Resource Management Review. 1995; (Winter)5(4):267-288

[21] Briscoe DB, Claus LM. Employee performance management: policies and practices in multinational enterprises. In: Budwah PW, DeNisi A, editors. Performance Management Systems: A Global Perspective. Abingdon: Routledge; 2008

[22] Mitroff II. Alpaslan CM, Green S. Crisis management: Cutting through the confusion. MIT Sloan Management Review. 1988;29(2):15

[23] Mathews JA. A resource-based view of Schumpeterian economic dynamics. Journal of Evolutionary Economics. 2002;12:29-54

[24] Mesch DJ, Perry JL, Wise LR. Bureaucratic and strategic human resource management: An empirical comparison in the federal government. Journal of Public Administration Research and Theory. 1995;5(4):385-402

[25] DeCenzo DA, Robbins SP.

Fundamentals of Human Resource

Management. Wiley. 2004.

https://books.google.gr/

books?id=mVpYAAAAYAAJ

[26] Cheung A. Public sector reform and the re-legitimation of public bureaucratic power-The case of Hong Kong. International Journal of Public Sector Management. 1996;9(5/6):37-50
[27] Mitroff II. Essential guide to managing corporate crisis:

A step-by-step guide. New York: Oxford University Press; 1996

[28] ISO 9000 family - quality management. Available from: https:// www.iso.org/iso-9001-qualitymanagement.html. [Accessed: 15 November 2019] 
Section 2

\section{Crisis Management in Practice}





\title{
Chapter 6
}

\section{Applying Monte Carlo Simulation in New Tech}

\author{
Levent Yilmaz
}

\begin{abstract}
Monte Carlo in Monaco is given to the theory for mathematics, whose simulation process involves generating chance variables and exhibiting random behaviours in nature. This simulation is a powerful statistical analysis tool and widely used in both non-engineering fields and engineering fields for new perspectives. This simulation has been applied to diverse problems ranging from the simulation of complex physical phenomena such as atom collisions, to the simulation of river boundary layers as meanders and Dow Jones forecasting. It can deal with many random variables, various distribution types and highly nonlinear engineering models, while Monte Carlo is also suitable for solving complex engineering problems in two areas which are varying randomly. Monte Carlo simulation is given as an application for hydrogen energy potential determination.
\end{abstract}

Keywords: Monte Carlo method, renewable energy, hydrogen potential

\section{Introduction}

Monte Carlo simulation, or probability simulation, is a technique used to understand the impact of risk and uncertainty in natural occurrences, project management, cost and other forecasting models [1]. You must make certain assumptions - for any model that plans ahead for the future-when you develop a forecasting model. In this research, there might be assumptions about the future shape of river curvatures which is called as river meanders. These are projections into the future, and the best you can do is to estimate the expected value. What the actual value will be you cannot know with certainty, but based on historical data, or expertise in the field, or past experience, you can draw an estimate value. It contains some inherent uncertainty and risk, because it is an estimate of an unknown value.

The Monte Carlo simulation performs random sampling and conducts a large number of experiments on computer, which is different from a physical experiment, At the first step, experimental statistical properties (model values) are given, and results for the model outputs are calculated with a computer program. According to the calculation procedure, the input random variables are distributed randomly. The output $\mathrm{Y}$ variables are given as a function of $\mathrm{x}$ in formula $\mathrm{Y}=\mathrm{g}$ $(\mathrm{x})$, where this function is called as performance function. After collecting the necessary input values from each experiment carried out in this manner, a set of samples of output variable $Y$ are available for the statistical analysis, which estimates the characteristics of the output variable Y. In Figure 1, the flowing 


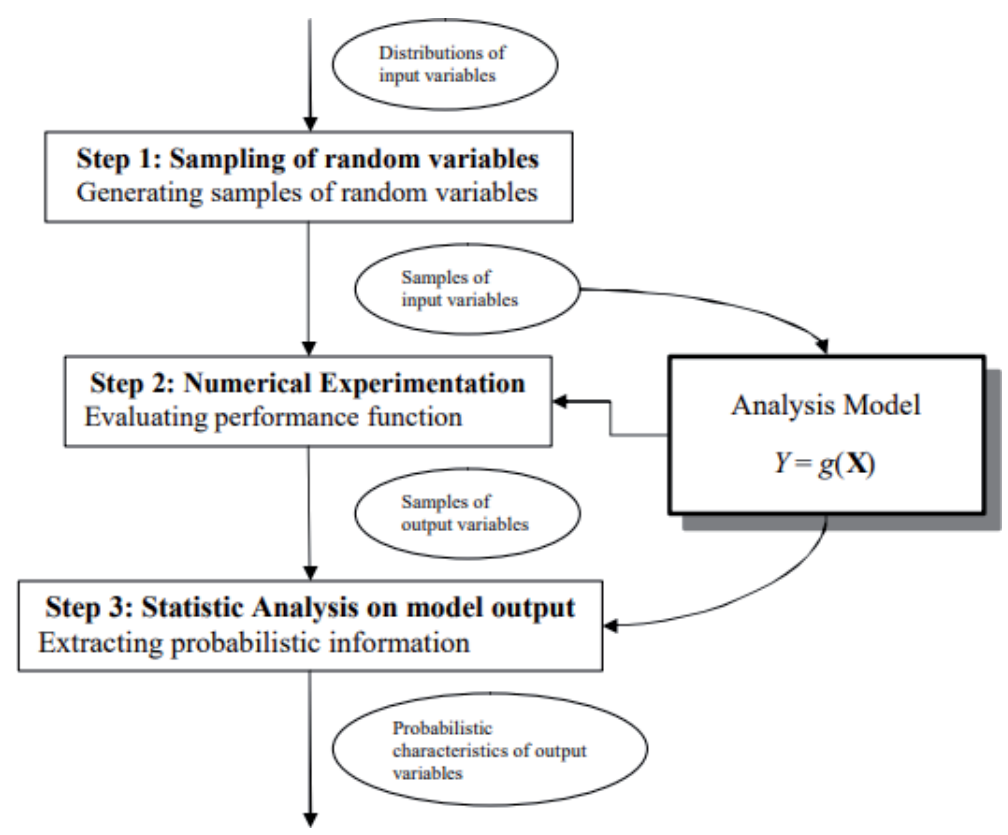

Figure 1.

Monte Carlo simulation [4].

computer chart is given as an example where the three steps are required in the simulation process:

Step 1: Sampling on random input variables $\mathrm{X}$.

Step 2: Evaluating model output Y.

Step 3: Performing statistical analysis on the model output.

The discussion about the choosing of independent random variables will be given. But, the Monte Carlo simulation is applicable for dependent variables where it is needed to follow the three steps [2].

Monte Carlo methods generally follow the following steps:

1. Determining the statistical properties of possible inputs.

2. Generating many sets of possible inputs that follow the above properties.

3. Performing a deterministic calculation with these sets.

4. Analysing statistically the results.

The error on the results typically decreases as $1 / \sqrt{ } \mathrm{N}[3]$.

\section{Application}

The Monte Carlo simulation is applied for determination of hydrogen energy potential where hydrogen can be used as a save energy without any pollution control like fossil fuels. The atomic construction of hydrogen consists of only one proton and one electron, which can be found in the universe easily. In the universe, 
hydrogen does not occur naturally as a gas on Earth, as it is always combined with other elements in our environment.

On the Earth, hydrogen can be found in organic compounds as hydrocarbons which can be used as gasoline, natural gas, earth gas and methanol or propane and with a heat separation procedure, it can be converted into reforming procedure. With electrolysis, hydrogen is separated from water into its component of oxygen where we can use this process for electrical energy. In sea boundary layer, some algae and bacteria, using sunlight as their energy source, even give off hydrogen under certain conditions. Hydrogen fuel is used by NASA as a fuel for space shuttles.

In praxis, hydrogen and oxygen combine in a fuel cell to produce electricity, heat and water where they are often compared with batteries for converting the chemical reaction into usable electric power. As long as fuel (hydrogen) is supplied, the fuel cell will produce electricity, never losing its charge.

For buildings, and as an electrical power source for electric motors propelling vehicles, fuel cells are new innovation for converting heat and electricity.

Hydrogen is a best energy carrier that is used by consumers in different ways. Other innovative energy sources, like the Sun and bioenergy, cannot produce energy all the time in the future where they could, for example, produce electric energy and hydrogen, which can be stored until it is needed. In the hydrogen generation, it can also be transported (like electricity) to locations where it is needed.

In scientific research, this simulation (Monte Carlo) is a new technique in science which forms random variables as input results for risk assessment or uncertainty of a certain system.

In new application on the basis of probability distributions such as normal, log normal, etc., the random variables or inputs are modelled, where different iterations or simulations are run for generating paths, and the outcome is arrived at by using suitable numerical computations.

In the application of Monte Carlo simulation for an exact solution, the hydrogen energy potential problem is solved by Monte Carlo simulation, which is used in a dynamic complex system that needs to be analysed, which is a probabilistic method for modelling risk in a system.

The Monte Carlo method is used also in physical science, statistics, artificial intelligence and robotics. In the example of the determination of hydrogen energy potential, the Monte Carlo simulation gives as a result a probabilistic estimate of uncertainty. But it is a useful tool for approximation of realty which gives never deterministic results.

The Monte Carlo simulation technique was observed in innovation extensively for modelling uncertain situations like hydrogen energy potential determination in renewable energy systems [5].

It is difficult to predict the real situation with absolute precision and accuracy, which can be attributed to the different parameters that can impact the outcome of a course of action. The Monte Carlo simulation can give all possible results for a new decision. It can thereby help us take improvements of a solution for a difficult situation under uncertainty. The probabilities of outcomes can be easily discussed by decision-makers.

For instance, the Monte Carlo simulation can be used to compute the value at risk of a portfolio where this method tries to predict the worst return expected from a portfolio, given a certain confidence interval for a specified time period. 


\section{Results}

In description of Monte Carlo simulation, this model can be easily calculated using the random value. A typical Monte Carlo simulation program can easily calculate the model verification by counting indefinitely, where each time they use different randomly selected evaluations.

As the result, the Monte Carlo simulation program is a very important program that was used also by Einstein's group in Manhattan Program for atomic bomb energy determination.

It is difficult to predict the real situation with absolute precision and accuracy which can be attributed to the different parameters that can impact the outcome of a course of action. The Monte Carlo Simulation can give all possible results for a new decision. It can thereby help us take improvements of a solution for a difficult situation under uncertainty. The probabilities of outcomes can be easily discussed by decision-makers.

\section{Description of program or function}

Super Monte Carlo simulation program for nuclear and radiation process (SuperMC), a general, intelligent, accurate and precise simulation software system for the nuclear design and safety evaluation of nuclear systems, is designated to support the comprehensive neutronics calculation, taking the radiation transport as the core and including the depletion, radiation source term/dose/biohazard, material activation and transmutation, etc. [6]. It supports multi-physics coupling calculation including thermo-hydraulics, structural mechanics, chemistry, biology, etc. The main technical features include hybrid MC-deterministic methods and the adoption of advanced information technologies, while the main usability features include automatic modelling of geometry and physics, visualisation and virtual simulation and cloud computing services.

The latest version of SuperMC can accomplish the transport calculation of $n, \gamma$ and can be applied for criticality and shielding design of reactors as well as analysis in medical physics.

SuperMC has been verified and validated by more than 2000 benchmark models and experiments, such as International Criticality Safety Benchmark Evaluation Project (ICSBEP), Shielding Integral Benchmark Archive and Database (SINBAD) and the comprehensive applications from the reactors including fusion reactor (ITER benchmark model, FDS-II), fast reactor (BN600, IAEAADS), PWR (BEAVRS, HM, TCA) and International Reactor Physics Experiment Evaluation Project (IRPhEP), etc. SuperMC greatly speeds up the neutronics analysis, especially for complicated problems. Based on this program, detailed and accurate nuclear analysis models can be created, and accurate nuclear analysis can be performed as well.

\section{Methods}

The methods used are the following:

- Monte Carlo transport methods of neutron and photon with series of novel acceleration methods for transport calculation. 
- Automatic CAD-based geometry modelling method with geometry decomposing algorithm and model reuse technique [7-11].

- 4D whole process intelligent and visualised analysis method including data visualisation mixed with calculation geometries.

\section{Restrictions on the complexity of the problem}

The energy range is $1.0 \mathrm{e}-11 \sim 150 \mathrm{MeV}$ for neutron and $1 \mathrm{keV} 1 \mathrm{GeV}$ for photon.

\section{Typical running time}

The running time is dependent on the complexity of problem.

\section{Unusual features of the program}

The unusual features are the following:

- CAD-based automatic geometry and physics modelling with high efficiency and precision.

- Efficient particle transport calculation based on particle uniformity and location anticipation.

- Multi-dimensional and multi-style intelligent visualisation analysis.

- Intelligent automation modelling, efficient computation and visualisation analysis based on cloud computing.

\section{Related or auxiliary programs}

MPICH2-1.4.1 is one of the related or auxiliary programs.

\section{Status}

$$
\begin{array}{lll}
\text { Package ID } & \text { Status date } & \text { Status } \\
\text { IAEA1437/01 07-JUL-2016 } & \text { Tested at NEADB }
\end{array}
$$

\section{Hardware requirements}

The following are the hardware requirements for the program:

Bottommost PC hardware configuration:

CPU: Dual-Core 1.5 GHZ

Memory: $512 \mathrm{MB}$

Hard disk space: 3 GB 
Recommended hardware configuration:

CPU: Dual-Core 3.0 GHZ

Memory: $4 \mathrm{~GB}$

Hard disk space: $10 \mathrm{~GB}$

\section{Programming language(s) used}

No specified programming language is used.

\section{Software requirements}

SuperMC can run on Windows XP 32-bit, Windows 7 32/64-bit and Linux CentOS 5.4/6.6.

\section{Author details}

Levent Yilmaz

Nisantasi University, Istanbul, Turkey

*Address all correspondence to: levent.yilmaz@nisantasi.edu.tr

\section{IntechOpen}

(C) 2020 The Author(s). Licensee IntechOpen. This chapter is distributed under the terms of the Creative Commons Attribution License (http://creativecommons.org/licenses/ by/3.0), which permits unrestricted use, distribution, and reproduction in any medium, provided the original work is properly cited. (cc) BY 


\section{References}

[1] Available from: https://www. riskamp.com/files/RiskAMP\%20-\%20

Monte\%20Carlo\%20Simulation.pdf

[2] Available from: http://www.riskAMP. com

[3] Available from: https://www.unige.ch/ sciences/astro/files/2713/8971/4086/3_

Paltani_MonteCarlo.pdf

[4] Available from: http://web.mst. edu/ dux/repository/me360/ch8.pdf

[5] Yilmaz L. Hydrogen Energy Potentıal Determination with Computational Mathematıcs. Riga, latvia, the European Unıon: Lambert Academıc Publishing/ SIA Publishing; 2018. ISBN: 978-613-987372-2. Available from: www.lappublishing.com

[6] Available from: http://www. oecd-nea.org/tools/abstract/detail/ iaea1437/\#i2

[7] Wu Y, Song J, Zheng H, et al. CAD-based Monte Carlo program for integrated simulations of nuclear system SuperMC. Annals of Nuclear Energy. 2015;82:161-168

[8] Wu Y, FDS Team. CAD-based interface program for fusion neutron transport simulation. Fusion Engineering and Design. 2009;84(7-11):1987-1992

[9] Song J, Sun G, Chen Z, et al. Benchmarking of CAD-based SuperMC with ITER benchmark model. Fusion Engineering and Design. 2014;89(11):2499-2503

[10] Li Y, Lu L, Ding A, et al. Benchmarking of MCAM4.0 with ITER 3D model. Fusion Engineering and Design. 2007;82:2861-2866

[11] $\mathrm{Hu} \mathrm{H}, \mathrm{Wu} \mathrm{Y,} \mathrm{Chen} \mathrm{M,} \mathrm{et} \mathrm{al.}$

Benchmarking of SNAM with the ITER 3D model. Fusion Engineering and Design. 2007;82:2867-2871 



\title{
Management of Tourism Crisis in the Middle East
}

\author{
Omar Jawabreh
}

\begin{abstract}
This study looks for to recognize the realism of management of tourism crisis in Jordan (Amman Hotels' Bombing case study). In order to show the role of the management and its effects in facing the tourism crisis in Jordan, the researcher will try to handle a group of points: finding a special concept for tourism crisis, crisis generative environment, management of tourism crisis, and studying Jordan management of the Hotel bombing in Amman. To clarify and achieve the objectives of the research, the researcher adopted the descriptive analytical approach to what is stated in the most important books and references Arab and foreign periodicals, statistics, and official reports relating to the ethics of the research. It is recommended, in this study, to provide training opportunities for all people who have a role in the management of tourism crisis especially in the communication sector, the massive presence of police in the tourism site, hotels, and all the tourism places under the condition of not being seen, and to provide the qualified policemen with modern defensive weapons.
\end{abstract}

Keywords: tourism crisis, hotel, Black Wednesday, tourism crisis management, Jordan

\section{Introduction}

The Arab region is crowded with political challenges, most notably the Arab Spring, and the Arab-Israeli conflict is a permanent and ongoing event that is constantly taken on the agenda of Arab and Jordanian tourism. The lack of financial allocations for marketing is not a new event in Jordan's tourism strategies. We add that there is a clear shortage of qualified human resources to work in the local tourism sector.

The Jordanian citizen does not accept tourism as it affects the value system and morals in the country; we find that the growth of mufflers and bars is faster than the growth of mosques or cultural and social centers, as well as being the main source of high prices and increased greed of traders, especially owners of restaurants and hotels, tourism makers in Jordan do not distinguish between foreign tourists and the Jordanian citizen (tourist).

According to recent statistics, the growth rate of the sector in Jordan will exceed 7\% during 2010-2019, while the global growth rate of tourism will reach 4\%; the number of hotels that will enter the Middle East market will reach 253 in the next Four years, in addition to 120,000 guest rooms.

The World Tourism Organization expects that the contribution of the sector to the GDP in Jordan will reach $23 \%$ by the end of 2020 , and provide (435) thousand jobs 
and is expected to increase the number of tunnel rooms during the same period, i.e., 10 rooms, and the participation rate of the tourism sector in the product Local to $17 \%$.

Some researchers have linked terrorism to tourism, including: Feridun [1], who examined the effects of terrorist attacks on the tourism sector on incoming tourism in Turkey during the period 1986-2006, and showed that the terrorist attacks negatively impacted on the economic side. Some researchers went on to link political, economic, and terrorism events to tourism development. Saha and Yap (2013) conducted a study on the impact of political instability and terrorism on tourism development in 139 countries for the period 1999-1999. The study showed the impact of political instability on tourism development. In addition, terrorism and political instability have also seriously affected the tourism industry. The study also examined the relationship between political instability, terrorism, and tourism in the SAARC regions, representing the countries of Pakistan, India, Sri Lanka, and Bangladesh during the period 2012-1995 [2-7]. In addition to many other data, such as the average tourist expenditure according to the average duration of stay in different tourist areas and other data, this rule should also include everything related to the tourism offer, various accommodation, employment, tourism transport sector, tourism companies, public tourist shops, entertainment places, special events, and festivals. This is in addition to the need to provide data and information on the impact of the tourism sector on the national economy, such as gross and net tourism income and the impact of this income on the balance of payments and capital invested in the tourism sector, tourism employment, tourism sector, and the growth rate of tourism and tourism sector compared to other sectors. Finally, this database should include data on domestic tourism and tourist offices at home and abroad, and data on the environment and its impact on the tourism sector. The role of the Ministry of Foreign Affairs at home and abroad is to clarify the real picture of foreign embassies inside Egypt and to foreign nationals abroad, in order to reduce the effects of this crisis, in addition to many other measures that complement these steps. After the crisis, there are a number of measures such as providing medical and psychological care for the injured tourists and citizens and the role of the Ministry of Information, Tourism, Foreign Affairs and Interior in containing the crisis and international tourism seminars and conferences, clarification and protection of tourism and nontourism. In Egypt, the world can feel the extent of security and safety enjoyed by Egypt. One of the crises is the Gulf War and the Crisis of the Egyptian Tourism Sector: the Egyptian tourism sector has suffered significant losses since the escalation of the Gulf War in August 1990 and even after the end of the war in February 1991. The Gulf War led to the decline of the Egyptian tourist season, by about $6 \%$, by about $60 \%$. Tourism movement (number of tourists) to about $27 \%$ in 1989 decreased to $9.3 \%$ in 1990 and then reached $80.14 \%$ in 1991 . It is clear to us that without the Gulf War and assuming a steady rate of growth of the number of tourists, in 1989, the number of tourists had reached more. The loss was not only limited to the number of tourists coming to Egypt, but also to the number of tourist nights spent in 1990, during the same period in 1990. The Gulf crisis has also led to the deterioration of several key sectors related to tourism activity such as hotels, tourism companies, public shops, ordinary traders, as well as the corporation. The direct loss of the tourism sector was estimated at about 3 billion pounds, but the losses were also about another 3 billion pounds, which means both direct and indirect losses [8-10].

In spite of many variable advantages that Jordan has, it still did not get the appropriate tourism position because of the many crises that face the tourism sector, the sensitivity of this sector, the intensity of its effect with crisis, and in specific, the terrorist attacks which aim to shake the trust in the Jordanian tourism [5, 11-23]. 


\section{Research background}

While it is premature to give an accurate assessment of the anticipated consequences of the deteriorating security situation that the country is complaining in this delicate situation, on the tourism sector as a whole, the indications so far indicate the widespread concern among some tourists who are planning to spend their holiday in Tunisia, while others cancel their reservations and change their orientation toward other safer countries. The tourism sector contributes about $7 \%$ of the GDP economic sector, which contributes about 7\% of the GDP, which is equivalent to 400,000 jobs directly. Because tourism activity is closely linked to other economic activities, such as trade, handicraft, and transport, the shrinking influx of inbound tourism negatively affects the income of these activities and indirectly threatens the employment of its workers.

El Hassan Achi is an economist in development, institutional economics, trade, and labor. His research focuses on the Middle East and North Africa.

While restoring security is an indispensable condition for improving the performance of Tunisia's tourism sector, it is not enough. If the crisis of the Gaza Strip has been exacerbated since the revolution due to the deterioration of the security situation and the increasing uncertainty about the trends of tourism policy after the victory of the Ennahda Party in the legislative elections and its leadership of the government, its roots were already due to structural factors related to the nature of the tourism product adopted by Tunisia as a field of specialization. The investment policy is the new trend for investment policy in the tourism sector during the period before the overthrow of the regime of President Zine El Abidine Ben Ali.

Tunisia's tourism sector has suffered from its excessive focus on medium-sized indoor beach resorts, which mainly receive low-income groups from the European Union. This trend suffers from low levels of profitability and is strongly influenced by economic conditions. It is clear from the data of the World Tourism Organization that the average revenue from tourist arrivals to Tunisia does not exceed $\$ 385$, which is the weakest at the level of tourist destinations around the Mediterranean. The average tourist revenue is $\$ 725$ in Morocco, \$ 770 in Turkey, \$ 890 in Egypt, and $\$ 1000$ in Greece.

One might say that Egypt has an income of 5 million and 400,000 tourists, which is a good number, but what is important in tourism is the income generated by tourism and not the number of tourists. The detailed view of the number of Arab tourists last year is as follows: 283,000 tourists from Libya, 77,000 from Iraq, 68,000 from Palestine, 63,000 and 500 Yemeni tourists, and 54,000 Syrian tourists; and from African countries, the detailed view is as follows: 44,000 tourists from Nigeria, 8000 from Ethiopia, and 3000 from Somalia.

There are fears that some Western countries are rushing to issue travel warnings to the South Sinai region (northeast of the country), with the term Sinai still associated with terrorist operations.

The number of tourists arriving in Egypt decreased by 13\% during the period from January to August, compared with the same period last year.

The total number of tourists coming to Egypt during the last 8 months was about 6.3 million, compared to 7.2 million in 2013, according to data from the Egyptian Ministry of Tourism.

Egypt's tourism income declined last year to $\$ 5.9$ billion, compared to $\$ 10$ billion in 2012 , down to $41 \%$.

Egypt is counting on the tourism sector to provide about $20 \%$ of foreign currency annually, while the volume of investments in the sector is estimated at 68 billion pounds ( 9.5 billion dollars), according to the Ministry of Tourism data. 
The peace treaty in 1994 contributed to the increase in the number of group tourists coming to Jordan from the American and European regions and nationalities more than the Arab countries in contradiction with the first hypothesis. The US and European regions and nationalities are more developed than Asia and the Pacific and the Arab countries representing countries that are incompatible and do not meet the second hypothesis. This indicates the impact of the positive security event related to peace in the region such as the Jordanian-Israeli peace treaty, which reflects the negative impact on the number of tourists coming to Jordan, which contributes to increase the number of tourists from distant regions and developed countries more than tourists from neighboring regions and developing countries.

Since 1967, Palestinian tourism has suffered a setback. Israel has seized Palestinian tourism capabilities and changed the Jordanian and Egyptian laws and regulations by military orders that serve only their interests.

The city of Jerusalem was isolated and Palestinian tourism companies were besieged by a series of decisions that prevent them from being able to withstand Israeli companies that have granted all facilities.

Israeli tourism companies have imposed conditions on tourist groups from around the world to visit the Holy Land, including staying in Israeli hotels, causing heavy losses to the tourism services sector in Palestine.

Here we should mention the destruction of many historical and archeological sites in Palestine, where excavations are carried out under the Al-Aqsa Mosque, sweeping away ancient historical tombs and many archeological sites. The Hebrew era was not able to abolish the Arab presence from Palestine, and did not extend for more than 8 years; in addition, this era came late in comparison with the history of Palestine's long history.

The tourism industry in Palestine can flourish with a just political solution leading to an independent sovereign Palestinian state, and the accompanying lifting of restrictions on travel, movement, tourism infrastructure development, and security and serenity.

The tourism sector was characterized by the influx of large numbers of investors close to the system in order to benefit from concessions, including the acquisition of land at low prices and access to bank loans in exchange for low interest rates and other facilities. At the same time, the sector professionals suffered from arbitrary decisions by the regulators, especially in the area of classification of tourist accommodation units and access to licenses. During the last 10 years, preceding the "Arab Spring," the number of tourists who chose Tunisia as a destination jumped from 5 to 7 million, while the number of people going to Morocco rose from less than 5 to more than 9 million during the same period. The number of people traveling to Turkey and Egypt has increased by $250 \%$.

To increase the tourism sector in Tunisia for the foreseeable future requires a reasonable level of stability and security, but the development of the sector and ensure its continuity in supporting economic growth and secure the jobs necessary to absorb the huge numbers of unemployment, especially among the educated youth, need to review in depth the tourism trends of the country.

Thus, the EU and its NATO ally, the United States, must modernize the intelligence equipment of the Tunisian security apparatus in order to detect early attacks that resonate with Western populations.

The Tunisian Ministry of Interior and Defense's budget increased by $31 \%$ in 2019 to combat domestic terrorism. Tunisia's economy and youth are known to have given the money, so the EU and the US should provide equipment, training, and security assistance to Tunisia instead of relying on the government to allocate funds to fight terrorism. Thus, the government will be able to reduce its defense expenditures to deal with youth unemployment and increase the wages of its citizens and 
economic development projects in marginalized and impoverished areas in order to quell the anger of the people and shape a better economic future.

Tunisia's tourism receipts have dropped significantly by $35 \%$, and the number of tourists has declined by $31 \%$, according to official statistics of the Tunisian Professional Tourism Complex.

The disaster also hit Egypt, which lost its rank on the list of tourist destinations in the world, as a result of the turbulent security events and air accidents, in addition to the prosecution of the group of Jerusalem's pro-ISIS in Sinai, which is responsible for the targeting of a Russian civilian aircraft, in addition to the recent terrorist attack that targeted the church of Saint Joseph.

A series of events led to a $46 \%$ decline in the number of visitors to Egypt in the first quarter of 2016.

The deterioration of tourism prompted officials to draw up an alternative plan to revitalize the sector, and find an alternative to the Russian tourist market, which represents nearly $90 \%$ of the total tourist arrivals to the Red Sea and Sinai resorts, so the Egyptian authorities resorted to stimulate domestic tourism and attract other nationalities from East Asia, Arab countries, and North Africa. But her plan failed.

Implications of the crisis: the incident of this crisis has resulted in the loss of human losses number of tourists such as death and workers in the Egyptian tourism sector as well as the result of the existence of financial losses, such as damage to some of the enterprises and some of the assets of some enterprises This crisis also had a significant impact, such as the panic and panic of many tourists. Citizens. The database and information must be available to manage a crisis in the tourism sector: there must be an integrated database for tourism data and information in order to successfully manage a tourism crisis. This rule should include everything related to tourism demand such as the number of tourists, tourist nights, tourism revenues, tourist destinations, and tourist destinations. Survival of the nationality of tourists.

The events and changes witnessed and witnessed in the Arab world have had a significant impact on the economic reality, and the crisis has included many sectors, most important of which are tourism. The tourism sector is considered strategic in many countries, including Tunisia, Egypt, and Syria, which remains one of the most prominent arenas of the "Arab Spring." The fact that these countries are nonoil, and poor in natural resources, relied heavily on their tourism returns, which declined significantly compared to the situation that existed before the recent political transformations.

Tunisia's tourism sector has been hit by the revolution of January 14, 2011 and has affected thousands of families whose livelihoods depend on occupations and businesses directly related to tourism and tourists, whether in the hotel sector or other tourism services, even those working in the traditional industries. All tourist indicators have fallen, as a result of various events directly affecting foreigners in Tunisia, such as the attack on the US embassy on September 14, 2012, the suicide bombing at the beach of a hostel in the tourist city of Sousse, and the attempt to blow up the synagogue on the tourist island of Djerba. But the tourism index rebounded last year, approaching what it was before the outbreak of the revolution in Tunisia.

Talking about tourism in Syria today may be misplaced, with the crisis in the country touching the simplest aspects of life. But it is one of the three Arab Spring countries that relied heavily on tourism, with the tourism sector accounting for $12 \%$ of their gross national income. Since the start of the popular protests on March 15, 2011, which turned into an armed conflict, the Syrian economy has declined and tourism is inactive. Tourism receipts have fallen by more than $94 \%$, with losses exceeding $\$ 2.2$ billion as of August 2013. Today, only a few tourists from Iran and Iraq are visiting the country, where only a handful of tourists from Iran and Iraq are 
visiting. The damage to tourism in Syria, which will be felt for a long time, when the country overcomes its plight, is not only in terms of tourism infrastructure, but also its long-term destruction and historical monuments throughout the country, especially in the northern region where archeological sites such as Aleppo are concentrated.

Libya and Yemen did not have an active tourism sector that can be stopped after the events witnessed. However, it should be noted that other Arab countries such as the United Arab Emirates and Morocco, and some Mediterranean countries such as Turkey, Croatia, and Greece, have benefited economically from the poor conditions of the Arab Spring countries [24].

\section{Research methodology}

To clarify and achieve the objectives of the research, the researcher adopted the descriptive analytical approach to what is stated in the most important books and references Arab and foreign periodicals, statistics, and official reports relating to the ethics of the research.

\section{Tourism crisis management}

Based on the statistics of UNWTO during the past decades, it is clear that the growth of tourism is increasing year after year, the report of the World Tourism Organization (United Nation World Tourism Organization) 2016 that there is an increase in the number of international tourist arrivals in 2015 by. It is expected to reach 1.8 billion tourists by 2030 , according to statistics and long-term studies 16 , but the problem is when we are in reverse, that is, a decline or a slowdown in this growth due to increased rates of security incidents, so that this varies While the tourist can understand the possibility of a natural disaster in a particular tourist destination, such as an earthquake or volcano, or tsunami, or heavy rain, or storms and hurricanes as non-human, and the probability of occurrence is predictable It is possible to avoid tourism at the time of the occurrence, and after the disappearance of the natural disaster and its effects, tourists can go to the tourist destination, which is a great deal of assurance and certainty, but the problem if there are security imbalances of man-made, political instability, terrorism and criminal crimes, and treatment Bad for the tourist The lack of security oversight makes the tourist cancel the idea of going to this place where security imbalances occur.

A well-known example of the impact of terrorist acts on tourism is the impact of the attacks on the World Trade Towers in New York on September 11, 2001, where the global demand for tourism in the United States decreased by 7.4\% in 2001 and 2002, and caused the unemployment of more than 10 million tourism employees. Globally, the hotel occupancy rate has fallen by more than $50 \%$ despite a $40 \%$ price reduction, which has led to a decline in tourism investment due to the decline in interest rates.

The Middle East and North Africa (MENA) region has long been a major attraction for tourists, with tourism being an important source of income and growth. In 2011, the tourism sector contributed an estimated $\$ 107.3$ billion, or $4.5 \%$ of GDP. According to the World Bank's 2013 report, but as a result of the social movements in the region and the economic instability in Europe, tourism has suffered a lot, and social movements have the ability to affect negatively. Availability of accommodation, and the potential target, and the disruption of travel plans, as reports show that the number of tourists coming to the region fell by $9 \%$ to 72 million in 2011, a decrease of 6.6 million in 2010 [25]. 
For example, in Tunisia, where the tourism sector plays a vital role in the economy and other fields, where the proportion of GDP is $18.6 \%$, where the sector suffered the most negative effects of social movements in 2011, international tourists fell to 5.1 million, an estimated $34.2 \%$. This figure was even lower than the number of arrivals in 2000 . Tourism receipts in Tunisia declined by $-27.3 \%$, an estimated $\$ 2.4$ billion.

Most destinations in the Middle East have experienced, directly or indirectly, social and political developments in the region Syria -14\%, Egypt -32\%, Lebanon $-24 \%$, Palestine $-15 \%$, and Jordan $-13 \%$.

Security problems, political violence, wars, coups, terrorism, unrest, and security threats have a major impact on tourism.

\subsection{This revision requires two issues}

The first is taking into account the demographic shifts in Europe, new trends in demand for cultural, environmental, and desert tourism, adventure tourism, and discovery. The World Tourism Organization estimates that nearly 40\% of tourism activity today is culturally related. These new forms of tourism are more profitable and less vulnerable to seasonal changes.

The second is opening new markets in order to diversify the sources of tourism revenues and overcome the situation of excessive dependence on European tourists, who now make up more than $80 \%$ of the tourism arrivals to Tunisia. Emerging markets in Asia and Latin America will be an important source in the coming years due to the improvement in the living standards of their populations and the development of air communications between different parts of the world.

Unfortunately, terrorist attacks targeting tourists are not new. Similar attacks took place in 2015 and 2018 as a result of the continued determination of terrorists to hit the strategic positions of the Tunisian economy, and these types of targeted attacks are unlikely to stop anytime soon. The city of Kairouan, shared on one of their Telegram channels, militants continued to focus on recruiting more people and vowed to target foreign tourists in Tunisia, exacerbating the country's current security and economic crisis.

Prior to the Arab Spring, Tunisia's tourism sector contributed 21\% of the country's gross domestic product (GDP), and despite its decline to $15.9 \%$ after the overthrow of Ben Ali, it rose again to about 18\% from 2012 to 2014. Then, the positive trend of Tourism's contribution fell again to $14.3 \%$ in 2015 after the terrorist attacks on the city of Sousse and the Bardo Museum. In the same year, Tunisia's per capita income fell from $\$ 4160$ to the pre-2007 level of \$3500, down to $19 \%$ [26].

It is in the interest of Western countries, particularly the European Union and the United States, to contribute to the fight against terrorism and extremism in Tunisia and to curb the spread of the terrorism export epidemic through the channel of illegal immigration.

Western policymakers have long voiced security concerns over their inability to detect all illegal immigrants from Tunisia and other Maghreb countries, especially since the West's alert for potential terrorist attacks which remains high and costly.

\section{Results and research findings}

Tourism is a sensitive industry for international and regional crises such as wars, acts of violence, and terrorism, as well as crime, corruption, deadly diseases, and other elements of national security. For example, war is tragic for tourism. Military 
activity can destroy infrastructure and cripple tourism investment. The civil war in Iraq, Lebanon, and Syria has severely damaged the tourism industry and paralyzed the domestic and foreign investments in these countries [4].

Political instability has implications on the local economy and employment at a time when the country needs foreign currency and on the benefits of economic development resulting from tourism, and it affects the tourism stability in tourism development by a likely decrease in domestic and foreign investment in tourism infrastructure and by increasing costs. Securing these investments decreases the international tourism movement, for example, the Middle East region due to wars and multiple conflicts such as the Arab-Israeli conflict such as: the Arab-Israeli conflict, the first and second Gulf war, the Israeli aggression in GNU. Lebanon 2006.

The security problems also talked about fluctuation in tourism revenues and tourism investment for several points, most notably:

1. The occurrence of terrorist and security events will be reflected negatively on those involved in tourism investment, such as businessmen and venture capitalists, because they fear the negative effects of security events and their various repercussions on their money and tourism projects to serious risks, which lead them to leave this activity and go to other activities that are more secure and profitable. This negatively affects the tourism investment.

2. The proliferation and increase of security problems and risks mean increasing the cost of securitization of tourism equipment and tourists. Rather than directing tourism revenues to invest in new facilities and equipment at international standards to attract more tourists, this money is directed to the security of tourism.

3. Continuous warning for traveling to the middle east from countries such as the United States, Canada, Australia, and Britain with security problems so that they are not exposed to risks such as being killed, injured, and kidnapped, which negatively affect tourism revenues and lead to a decline in tourism investment.

4. As a result of the various leaps in the professional side of the threats to tourism, such as terrorism, in the last three decades, professionalism in directing attacks on elements of tourism investment, such as hotels, tourist facilities, and transport, has been monitored, in order to achieve the greatest publicity and information on the one hand, and on the other hand, cause serious damage to tourism investments.

\subsection{Routine crisis and sudden crisis}

In forming a committee to study the crisis, this way is used when no information is found about the real power who makes this crisis and who has an interest in making it, or in lessening the value and importance of the crisis. Or in giving vent to the crisis which is called the venting of the volcano, and finding different alternative paths in front of the pushing force that generated the crisis and its flow to change it to other different alternative paths which can contain its strength and reduce its danger, or in isolating the strength of the crisis through observing and defining the generated power and isolating it from the path of the crisis to prevent its spreading and expanding and consequently making it easier to deal with, solve, or even eradicate it [27]. 
The untraditional ways of dealing with crises are more important because it became more proper to the sole of the time and more harmonious with the nature of its changing, but because it important and wide spread, we can talk about it in a separated study [28-52].

\subsection{Reasons for these kinds of tourism crises}

The reasons can be limited to the confusing relationships between the touristic companies outside and inside, either in financial settlement or in the disturbance of carrying out the touristic programs; pressure made by the tour operators on their agents in the host county to get less prices; steering the movement by the tour organizers to a certain places without taking into consideration the social and environmental cost; and not educating the tourists of all the acceptable and not acceptable behaviors in the host country so that the tourist will not behave in an unacceptable way.

\subsection{Amman hotels explosions}

\subsubsection{Black Wednesday}

On 9/11/2005, three terrorist explosions happened using explosive built, and they were aimed to three hotels in the middle of the Jordanian capital Amman; the first one happened at half past nine local time of Amman at the entrance of Radisson sass hotel; the second one in Hyatt Amman, and after few minutes, new one aimed Days Inn Hotel; the first estimated casualty number were about 57 and over 115 wounded. The main reason for this high number of casualty is the explosion in Radisson Sass Hotel, because it happened during a wedding; Al-Qaida adopted the responsibility for these explosions.

\subsection{The readiness security and safety strategy}

Political instability affects the Middle East on the number of foreign and Arab tourists coming to Jordan, and the proportion of its contribution to GDP during the period (2014-1990), the study showed that the number of foreign tourists and the proportion of their contribution to GDP decreased political events while the number of Arab tourists witnessed a positive rise and increase it in GDP. Any terrorist incident is a dagger in the heart of the country in general and tourism in particular, and the government is expected to completely recover by the end of 2014 and target between 13 and 14 million tourists.

The relative stability of the security situation coincides with the beginning of the study at universities that were accompanied by deliberate violence, and therefore, the negative effects on tourism from these terrorist operations cannot be underestimated despite the statements of officials.

The return of tourism to 2010 rates, In the light of security stability, within the framework of focused tourism marketing programs through global and regional tourism markets, which target new markets to attract tourism to Egypt by opening new tourist markets including India, China, Central Asia and other markets, in addition to taking the necessary measures to revitalize Egyptian tourism to its natural form. Again, the most important of which is to achieve security and safety and not to cut off the electricity that has become a means of "extinguishing" tourists. It is necessary to confront terrorist operations and develop a security plan to impose a security cordon around tourist areas to 
prevent the leakage of criminal and outlaw elements. In order to prevent any attacks on tourist areas besides securing the roads leading to all tourist places, especially that Egyptian tourism is targeted and must work to achieve security and safety to attract tourists again, because tourists are afraid to come to Egypt because of security events, even if they are not serious, because we need To erase the fear of the tourist's memory, which has crammed for fear of repetition of violence and terrorism that will not recognize borders or nationalities, and has not accompanied the humanitarian, religious and moral attitudes that prevent attacks on peaceful civilians, who have no political or sectarian orientations, and to print in his memory A new and bright mental image to fix their memory to accept what calls for confidence and reassurance, especially as social media publishes a lot of videos that show the unrest and security problems in Egypt in a panic to tourists, and that tourism companies could not face this by marketing Egypt as a tourist unlike other countries that have succeeded In marketing itself, despite its poor tourism and archeological components, we must realize that the repetition of terrorist operations has negative effects on the flow of incoming tourism, coupled with the decline in the volume of domestic and foreign investments in the tourism sector, which affects the tourism industry in the future. $\mathrm{B}$, and then develop a comprehensive strategy for tourism development plan is required to face all the possibilities and the negatives facing the tourism industry, until you find a way to recover and attract more Arab and foreign investments, rather than escaping out of the area.

\subsection{The readiness strategy in communication sector}

The successful response in any emergency situation depends on the fastness of communication, and to make this ability to communicate successfully, there must be a detailed base of everybody that has a relation in the crisis management necessary to communicate.

The most important way of communication is the telephone, then comes the roll of emails and the site of tourism activation institution. But if all communications through telephones in emergency situation failed, the other alternative equipment's could be used, like wireless telephones and global telephones which must be available and the people in the responding group must be trained to use them.

It goes without saying that the entire tourism sector must talk in one voice, and the immediate responding group decides the desired massage to be sent, and it is delivered by the minister of tourism and antiques (spokesperson) in a press conference and interviews made by the mass media. For the group in charge of delivering, it follows the daily stuff related to the media and provides with the newest about the crisis through making a news journal about the crisis and renews their information on the electronic site.

At the same time, communication must be made with the tourism partners for Jordan in the outside world, the local tourism sector, the embassies, and the foreigner diplomatic delegation in Amman, and to make this communication effective, there must be an explicit and up-to-date information base that stores on computers about the following authorities to be provided with any new or any information related to the crisis.

\section{Conclusion}

Communication skills are the key to successfully manage any tourism crisis, through successive tests show that the first 24 hours of the event is decisive, the first 
message when the crisis happen must be quick, media constantly looking for more details about the incident, it is necessary to resist any desire to speculate and hence the importance of speed in delivering the required message and provide further information on an ongoing basis so as not to have a picture based on speculation. Successful communication policy of crisis management is based on the following concepts.

Tourism is a sensitive industry for international and regional crises such as wars, acts of violence and terrorism, as well as crime, corruption, deadly diseases, and other elements of national security. For example, war is tragic for tourism. Military activity can destroy infrastructure and cripple tourism investment. The civil war in Iraq, Lebanon, and Syria has severely damaged the tourism industry and paralyzed the domestic and foreign investments in these countries.

Political instability has implications on the local economy and employment at a time when the country needs foreign currency, and on the benefits of economic development resulting from tourism, and it affects tourism stability in tourism development by a likely decrease in domestic and foreign investments in tourism infrastructure, and by increasing costs. Securing these investments and decreasing the international tourism movement, for example, the Middle East region due to wars and multiple conflicts such as the Arab-Israeli conflict such as: the Arab-Israeli conflict, the first and second Gulf war, the Israeli aggression in GNU. Lebanon 2006.

The security problems also talked about fluctuation in tourism revenues and tourism investment for several points, most notably:

1. The occurrence of terrorist and security events will be reflected negatively on those involved in tourism investment, such as businessmen and venture capitalists, because they fear the negative effects of security events and their various repercussions on their money and tourism projects to serious risks, which leads them to leave this activity and go to other activities that are more secure and profitable. This negatively affects tourism investment.

2. The proliferation and increase of security problems and risks means increasing the cost of securitization of tourism equipment and tourists. Rather than directing tourism revenues to invest in new facilities and equipment at international standards to attract more tourists, this money is directed to the security of tourism.

3. Continuous warning for traveling to the middle east from countries such as the United States, Canada, Australia, and Britain with security problems so that they are not exposed to risks such as being killed, injured, and kidnapped, which negatively affect tourism revenues and lead to a decline in tourism investment.

4. As a result of the various leaps in the professional side of the threats to tourism, such as terrorism, it has been monitored in the last three decades professionalism in directing attacks on elements of tourism investment such as hotels, tourist facilities and transport in order to achieve the greatest publicity and information on the one hand, on the other hand, these attacks lead 22, causing serious damage to tourism investments.

This effect extends to all activities related to tourism investment only. In the event of security uncertainty, investors will stop repaying loans obtained from banks, as well as interest, in addition to stopping the use of tourist establishments or making new openings, which leads to slower investment rates. 
Despite the many disasters experienced by Egyptian tourism in recent years, such as the Luxor massacre in 1997, the crash of an Egyptian plane in the Gulf of Aqaba with 133 French tourists in January 2004, the bombing of the Taba hotel in October 2004, and the Sharm El Sheikh bombings in July, the negative impact of these events did not reach the level of tourism last year.

The number of tourists has dropped to 5430 million, while tourism income fell to 2.6 billion dollars that did not happen in 21 years, where the tourism income in 1995-1996 more than 3 billion dollars, but last year saw a phenomenon He spoke before, when the value of Egypt's tourism payments outside Egypt, which amounted to $\$ 4$ billion and 100 million, exceeded the income of tourism in Egypt.

Interestingly, the number of nights spent by tourists from all sides decreased, which negatively impacted on tourism income, as the increase in income is linked to the number of nights spent by tourists, an average that witnessed a remarkable decline to 6.2 nights last year compared to more than 12 nights a year ago. Despite the increase in the number of Arab tourists by $13 \%$, the number of Arab tourist nights decreased by $21 \%$.

\subsection{Recommendations and proposals}

Providing Staff training has a part in crisis management of tourism, specifically in communication skills. The intense security presence in tourist areas, hotels, and all tourist establishments, provided that it is invisible and to provide the qualified security men with modern defense weapons.

\section{Author details}

Omar Jawabreh

Hotel Management Department, Faculty of Tourism and Hospitality,

The University of Jordan, Aqaba, Jordan

*Address all correspondence to: o.jawabreh@ju.edu.jo

IntechOpen

(C) 2020 The Author(s). Licensee IntechOpen. This chapter is distributed under the terms of the Creative Commons Attribution License (http://creativecommons.org/licenses/ by/3.0), which permits unrestricted use, distribution, and reproduction in any medium, provided the original work is properly cited. (cc) BY 


\section{References}

[1] Feridun M. Impact of terrorism on tourism in Turkey: Empirical evidence from Turkey. Applied Economics. 2011;43(24):3349-3354. DOI: $10.1080 / 00036841003636268$

[2] González-Herrero A, Pratt C. Preventive marketing for crisis communications in tourism: Management strategies in the USA and Spain. Journal of Communication Management. 1998;3(1):9-25. DOI: 10.1108/eb023481

[3] Al-Omari I, Ali M, Mahmoud R, Jawabreh $O$. The Arab spring impacts on the Jordanian hotels sector. International Journal of Humanities and Social Science. 2015;5(44):159-171

[4] Alsarayreh M, Jawabreh O, Helalat M. The influence of terrorism on the international tourism activities. European Journal of Social Sciences. 2010;13(1)

[5] Liu B, Pennington-Gray L, Klemmer L. Using social media in hotel crisis management: The case of bed bugs. Journal of Hospitality and Tourism Technology. 2015;6(2):102-112. DOI: 10.1108/JHTT-08-2014-0036

[6] Little John R. Crisis Management: A Team Approach. New York: AMA; 1993

[7] O'Connor N. Crisis Management in the Tourism Industry-Beating the odds? International Journal of Contemporary Hospitality Management. 2010;22(4):582-584. DOI: $10.1108 / 09596111011042776$

[8] Pforr C, Hosie P. Crisis management in the tourism industry: Beating the odds? Disaster Prevention and Management: An International Journal. 2010;19(4):515-515. DOI: 10.1108/ dpm.2010.19.4.515.2

[9] Angel K, Menéndez-Plans C, Orgaz-Guerrero N. Risk management:
Comparative analysis of systematic risk and effect of the financial crisis on US tourism industry: Panel data research. International Journal of Contemporary Hospitality Management. 2018;30(3): 1920-1938. DOI: 10.1108/IJCHM03-2016-0173

[10] Malhotra R, Venkatesh U. Pre-crisis period planning: lessons for hospitality and tourism. Worldwide Hospitality and Tourism Themes. 2009;1(1):66-74. DOI: $10.1108 / 17554210910949896$

[11] Paraskevas A. Crisis management or crisis response system?: A

complexity science approach to organizational crises. Management Decision. 2006;44(7):892-907. DOI: 10.1108/00251740610680587

[12] Jayawardena C. Tourism in Niagara: Conclusions and solutions. International Journal of Contemporary Hospitality Management. 2008;20(3):360-368. DOI: $10.1108 / 09596110810866163$

[13] Miller DMS, Gonzalez C, Hutter M. Phoenix tourism within dark tourism: Rebirth, rebuilding and rebranding of tourist destinations following disasters. Worldwide Hospitality and Tourism Themes. 2017;9(2):196-215. DOI: 10.1108/WHATT-08-2016-0040

[14] Fayez A et al. Tourism Security. Riyadh: Naif Arab University for Security Sciences; 2004

[15] Sawalha IHS, Eid Jraisat L, Al-Qudah KAM. Crisis and disaster management in Jordanian hotels: Practices and cultural considerations. Disaster Prevention and Management: An International Journal. 2013;22(3):210-228. DOI: $10.1108 /$ DPM-09-2012-0101

[16] Costa J, Gomes J, Montenegro M. Did the context of economic crisis affect the image of Portugal as a 
tourist destination?: Strategic question overview. Worldwide Hospitality and Tourism Themes. 2014;6(5):392396. https://doi.org/10.1108/ WHATT-09-2014-0025

[17] Hvass KA. Tourism social media and crisis communication: An erupting trend. In: Munar AM, Gyimóthy S, Cai L, editors. Tourism Social Media: Transformations in Identity, Community and Culture, Tourism Social Science Series. Vol. 18. UK: Emerald Group Publishing Limited; 2014. pp. 177-191

[18] Selmi N, Dornier R. Perspectives on the destination image of Tunisia. Worldwide Hospitality and Tourism Themes. 2017;9(5):564-569. DOI: 10.1108/WHATT-07-2017-0037

[19] Cave P. The impact of the Asian economic crisis on tourism in Singapore. The Tourist Review. 1999;54(3):50-54. DOI: 10.1108/eb058315

[20] Stone P. Dark tourism scholarship: A critical review. International Journal of Culture, Tourism and Hospitality Research. 2013;7(3):307-318. DOI: 10.1108/IJCTHR-06-2013-0039

[21] Marshall R, De Villiers R. Marketing tourists gazing into the tourism domain. International Journal of Culture, Tourism and Hospitality Research. 2015;9(4):417-422. DOI: 10.1108/ IJCTHR-08-2015-0087

[22] Brito SP. Portuguese tourism-Facing the crisis. Worldwide Hospitality and Tourism Themes. 2014;6(5):442-451. DOI: 10.1108/WHATT-09-2014-0028

[23] Yuan YY. Adding environmental sustainability to the management of event tourism. International Journal of Culture, Tourism and Hospitality Research. 2013;7(2):175-183. DOI: 10.1108/IJCTHR-04-2013-0024

[24] Fin R, Salven G. Personality and emergence commendably. Disaster
Prevention and Management. 1996;1(5):14-36

[25] Jawabreh O. An exploratory study of the motives of Jordanian out bound tourism and its impact on the development of tourism in Jordan. International Journal of Applied Business and Economic Research. 2017b;15(19 Part-II):443-467

[26] Jawabreh O. Distinction of Jordan as a destination for religious tourism. Journal of Environmental Management and Tourism. 2017a;6(22):1171-1182. DOI: $10.14505 /$ jemt.v8.6(22).03

[27] Al-Khazraji T. International Political Relations and Crisis Management Strategy/An analytical study of the tourism sector (the reality of tourism in Jordan). Oman/Oman: Dar Mgdlaoi Publishing/Department of Studies and Information, Ministry of Tourism and Antiquities; 2005

[28] Abu Gahef A. Strategic Management and Crisis Management. Alexandria: The new University House; 2002

[29] Alsarayreh MN, Jawabreh OAA, Alkharabsheh KS, Aldahamsheh MM. Tourism promotion through the internet (websites): (Jordan as a case study). Asian Social Science. 2011;7(6). DOI: 10.5539/ass.v7n6p125

[30] Al-Shawagfih K, Alananzeh O, Jawabreh $\mathrm{O}$. The foundations of selecting cultural tourism product in Jordan. European Scientific Journal. 2015;11(29)

[31] Amari A. Crisis Management in a Changing World. Egypt: The Pyramids, Cairo Institution; 1993

[32] Baker DMA. The effects of terrorism on the travel and tourism industry. International Journal of Religious Tourism and Pilgrimage. 2014;2(1). DOI: 10.21427/D7VX3D. Available from: https://arrow.dit.ie/ijrtp/vol2/iss1/9 
[33] Chowdhury AM, Raj R, Griffin K, Clarke AP. Terrorism, tourism and religious travellers. International Journal of Religious Tourism and Pilgrimage. 2017;5(1). DOI: 10.21427/D7BD8G. Available from: https://arrow.dit.ie/ ijrtp/vol5/iss1/3

[34] Cohen EH. Tourism and terror: A case study: Israel 1948-2012. International Journal of Religious Tourism and Pilgrimage. 2014;2(1). DOI: 10.21427/D7CX2P. Available from: https://arrow.dit.ie/ijrtp/vol2/iss1/5

[35] Clayton A, Mustelier LC, KorstanjeMEP.Understandingperceptions and attitudes to risk in the tourism industry. International Journal of Religious Tourism and Pilgrimage. 2014;2(1). DOI: 10.21427/D70Q6Q. Available from: https://arrow.dit.ie/ ijrtp/vol2/iss1/8

[36] Das A. The Politics of Pilgrimage Through the Prism of Mass Media. International Journal of Religious Tourism and Pilgrimage. 2016;4(6). DOI: 10.21427/D7J13N. Available from: https://arrow.dit.ie/ijrtp/vol4/iss6/10

[37] Hale J. Crisis response communication challenges. Journal of Business Communication.

2005;2(42):211-223

[38] Howie L. Security guards and counter-terrorism: Tourism and gaps in terrorism prevention. International Journal of Religious Tourism and Pilgrimage. 2014;2(1). DOI: 10.21427/ D74D90. Available from: https://arrow. dit.ie/ijrtp/vol2/iss1/7

[39] Khaleefah QQ, Jawabreh OA, Najdawi BMA, Mahmoud RM. Why Arab societies do not encourage the work of their members in hotels? Modern Applied Science. 2018;12(11):259. DOI: 10.5539/mas.v12n11p259

[40] Korstanje MEP, Skoll G, Timmermann F. Terrorism, tourism and worker unions: The disciplinary boundaries of fear. International Journal of Religious Tourism and Pilgrimage. 2014;2(1). Available from: https://arrow. dit.ie/ijrtp/vol2/iss1/4

[41] Kovooe R. Crisis preparation in technical organization: A strategy using a multidimensional approach [Ph.D dissertation]. Irbid, Jordan: Yarmouk University; 1993

[42] Ludwing E. How to prepare for your inevitable crisis. American Banker. 2005;34(170):10-15

[43] Muhammad A. Tourist Security between Concept and Application in Jordan. Oman: Ministry of Tourism and Antiquities; 2006

[44] Muhanna M. Crisis Management. Egypt: Youth Foundation, University of Alexandria; 2004

[45] Michael B. Towards a Theory of International Crisis Behavior. Progress and Prospects for Applied Forecasting and Management. USA: SAGE Publishing; 1979. pp. 39-74

[46] Philips N. Setting up a crisis recovering plan. Journal of Business Strategy. 1986;4(6):34-51

[47] Reynolds M. Crisis emergency risk communication as an interactive model. Journal of Health Communication. 2005;6(10):110

[48] Reilly A. Strategic preparation for crisis management in the banking industry [Ph.D dissertation]. Irbid, Jordan: Yarmouk University; 1989

[49] Schroeder A, Pennington-Gray L, Bricker K. Lessons learnt from the Westgate shopping mall terrorist attack in Nairobi, Kenya: Involving the meetings, incentives, conferences and exhibitions sector in crisis communications. International Journal of Religious Tourism and Pilgrimage. 
2014;2(1). Available from: https://arrow.

dit.ie/ijrtp/vol2/iss1/6

[50] Stadbauer k. Managing Industrial

Crisis Successfully [dissertation].

Tennessee: University of Tennessee;

1991

[51] Tarlow P. Reflective epilogue:

Concerns in tourism safety.

International Journal of Religious

Tourism and Pilgrimage. 2014;2(1).

DOI: 10.21427/D7R726

[52] Terrington D. Effective

Management: People Organization.

New York: Hall Books; 1989 


\title{
Exploring the Three-Way Destination Safety Solution to Crisis Management in Tourist Destinations in Rural Nigeria
}

\author{
Elochukwu A. Nwankwo
}

\begin{abstract}
Development of tourist destinations is among topical issues in national discourse for economic growth and sustainability. The past two decades have witnessed massive development and investment in tourist destinations in rural areas. This is owing to the fact that rural tourism has been identified as among the development options for rural communities in most developing nations. Of recent, crisis and other safety issues have been among the militating factors against tourist destinations hence the cry for destination safety. These are said to emanate from the activities of the three major principals in the management of tourist destinations (hosts, tourism resources, and tourists/visitors). Incidentally, destination safety discourse is source of worry for these principal factors in tourist destination management. This has left many tourist destinations devastated, abandoned and abused. However, this chapter proposal would seek to identify the way out of this predicament. It tends to explore the meaning and application of the three-way destination safety (TWaDeSS) model in the management of crisis at tourist destinations in rural Nigeria. This will not only promote harmony among the three major principals in tourist destination but also enhance the rate of investment as a result of quality crisis control in these destinations.
\end{abstract}

Keywords: crisis management, tourist destinations, destination safety, three-way safety solution, rural areas, tourist safety, rural tourism

\section{Introduction}

It is no more news that the state or nature of tourist destinations promotes tourist inflows. This is applicable to all kinds of tourist destination not minding the location and/or ownership. Some notable tourism theories, like Sunlust and Wonderlust theory [1], pull and push theory [2] and inner-directed and out-directed theory [3], give further explanations to the position of tourist destinations in the determination of the extent of tourist inflows as a result of tourist choices. The implications being that the destination's image and nature control over $75 \%$ of tourist choices to visit or not to visit the destination. Adequate branding and relevant sustainable management practices are among the solutions to sustainable tourism development. 
Various kinds of tourist destinations abound, but emphasis here is on rural tourism which has been defined as a kind of tourism experience that has to do with visits to rural communities or villages that are separated from urban areas. Attractions that motivate such tourism experiences include sociocultural life styles and astonishing natural landscapes, among others [4, 5]. Moreover, Nwankwo et al. [6] informed that rural tourism is a motivation for self-development option for those living in the rural areas. This view was also supported by Tsephe and Obono [7] when they gave benefits of rural tourism to include foreign exchange earnings, creation of employment, opportunities for culture exposition and improved infrastructural and superstructural base, among others.

Many rural communities from various geopolitical zones of Nigeria have made frantic efforts to benefit from the gains of rural tourism, through harnessing of various tourism resources that have been lying fallow in their localities. Also many relevant academic researches and media documentations have directed the focus of these rural communities to those areas they have comparative advantage, to generate more tourist/visitors inflows to their communities. Despite these, rural tourism in Nigeria has been faced with some problems over the years, thereby depriving most of these rural communities of the opportunity to maximize the gains of rural tourism to rural development and sustainability. Among the critical aspects of these challenges is the issue of destination crisis that have ravaged the growth and sustainability of rural tourism initiatives in rural areas in Nigeria. However, this study is an attempt to seek for ways of tackling these challenges and to check various crises that have huge negative implication for sustainable tourism development in rural areas. To this regard, this study is aimed at considering the application of three-way destination safety solution to crisis management in rural Nigeria.

\section{Concept definitions}

There are some concepts in this study that may need further clarifications to enhance understanding of the basic argument in the study. Some of these concepts include tourist destination, tourist safety, host safety, tourism investment safety and destination safety, among others. Both the general understanding of these concepts and their peculiar understanding for the purpose of this study shall be briefly considered.

First and foremost, tourist destination has to do with a definite location with interesting tourist attractions/motivations. Such locations have the tendencies of attracting tourists and other visitors from different places. Alyward [8], Mannell and Iso-Ahola [9] and Basher and Ajloni [10] in their separate studies see tourist destination as a particular location with active pull factors for tourism experience and that of visitor experience for nontourists.

Tourist safety is another widely used concept in this study that needs clarifications. For the purpose of this study, tourist safety is defined as all the hazards and their control measures that pertain to tourists in a given tourist experience. From this definition, tourist safety is approached from two dimensions. The first looks at all the hazards and threats against the lives, properties and peace of tourists including their causes, while on a particular tourist experience. Measures have to do with all the control measures that have been designed to check those hazards whether sufficient or insufficient, active or passive or efficient or inefficient [11-13]. The state of tourist safety for a particular tourist destination is among the determining factors for the growth and sustainability of the destination. 
Host safety as a concept has to do with the total state of safety for the members of the host community who are living within the tourist destination. For the purpose of this study, this safety has to do with the feeling and condition of safety of the host with respect to tourism activities in their locality. This is pertinent; hence their feeling of perilous in their environment as a result of an existing tourism project in their area could be detrimental to the growth and sustainability of such tourism projects.

Moreover, tourism investment safety is the state of safety of tourism projects or schemes in a given locality. This is comprised of safety threats, their causes and existing measures to check those safety threats, for a particular tourism project or investment. Unsafe tourism investment will not only deter further or future investments but will equally hamper sustainability of the existing tourism projects and undermine the potentialities of various underdeveloped tourism resources in a particular locality. Activities of members of the host community, dubious visitors/ tourists and unchecked criminal activities can contribute to poor safety state of tourism projects.

Another notable concept used in the study is destination safety. This is quite different from host safety. Destination safety has to do with overall safety of the tourist destination. In this case, both the safety of hosts, tourists/visitors, tourist attractions, tourism projects and some other safety demands in the destination are considered. Unsafe tourism destination undermines existing and prospective tourism projects in a particular locality $[6,11,14]$. The state of safety for tourist destination has many implications for the pull factors of the destination in tourist's perceptions and assumptions while making destination choices.

I have tried to briefly look at the definitions and meanings of some of the notable concepts in this study. The next discourse will be on rural tourism and crisis management in rural Nigeria.

\section{Rural tourism and crisis management in rural Nigeria}

Rural tourism as a concept was briefly considered in the previous subheading as a kind of tourism activity that is motivated by tourism resources in the rural areas. In such tourism activities, the "pull factors" are always from the sociocultural aspects of the people and their natural landscapes, where some natural formations like forests, caves, rivers, rock shelters and mountains, among others, form part of the pull factors. Nigeria as a nation has many rural areas with high poverty level as a result of much public and private sector concentration on the urban and semiurban areas for meaningful development and investments in the infrastructural superstructural base. Also, the incessant rural to urban migration has not helped matters as the constant desire of rural dwellers to migrate to the urban and semiurban areas has contributed to huge instability in the labour and skill force of the rural areas in the country. Agriculture and tourism are being explored to give relevance to these rural communities by boosting their economic base.

Most of the rural communities in Nigeria are blessed with notable tourism resources that have potentialities for socio-economic development if carefully harnessed. These tourism resources in the rural areas in Nigeria are classified into two: natural tourism resources and cultural tourism resources. Natural tourism resources in these rural communities include caves, rock shelters, rock overhangs, waterfalls, mountains, rivers and streams, forests and other natural formations. The cultural tourism resources include the sociocultural aspects of the people like 
traditional dances, notable festivals, masquerading, attractive ceremonies, food typologies, belief systems and ritual practices and traditional outfits or attire, among others.

However, some of these rural communities have harnessed some of their tourism resources for meaningful tourism development that would improve their standard of living. While some of these communities have actualized their rural tourism base and transform their respective communities to rural tourist destinations, their counterparts have not been able to achieve similar heights, thereby leaving their tourism resources in a deplorable state.

Crisis has been defined as "...negative changes in the security, economic, political, societal, or environmental affairs, especially when they occur abruptly, with little or no warning" ([15], p. 3). In tourism studies or management, crisis can be said to be unwanted circumstance that come with huge negativities on the tourist destination, host community, tourists, visitors, tourist attractions and tourism schemes or project in a given area. The consequences are better imagined than witnessed as it might lead to the closure or abandonment of tourism projects or schemes in a given area. In most cases huge capital investments and natural resources are lost to this situation. The causes could either intrinsic or extrinsic depending on the nature of the crisis. Intrinsic has to do with those crises that are caused from within the tourism project circle, i.e. the stakeholders and/or natural factors. The stakeholders may include members of the host community, visitors/tourists, tourism project managers, tourism project developers and tourism resources (developed or undeveloped), among others. The natural factors has to do with some unforeseen natural occurrences like earthquakes, erosion, heavy rains, weather conditions, volcanoes, land movements and some other similar natural occurrences that are not within the control of man. Then the extrinsic factors have to do with some other factors that could cause crisis that are not within the list given above. It could be persons outside of the defined stakeholders, intercommunal crisis, invaded criminal activities and legal litigations from outside the community, among others.

Crisis management on other hand has been defined as "...the overall coordination of an organisation's response to a crisis, in an effective, timely manner, with the goal of avoiding or minimizing damage to the organisation's profitability, reputation, or ability to operate and often involves the need to make quick decisions on the basis of uncertain or incomplete information" ([15], p. 3). In tourism management, crisis management can be said to be programmes designed and implemented to check possible crisis in tourist destinations or on tourism projects with the aim of either avoiding the crisis and its consequences or managing or controlling the consequences of both expected and unexpected crisis at tourist destinations. This view was supported by Colpofer [15] in the following lines:
CM includes the development of plans, based upon an integral approach with internal and external organizations to reduce the risk of a crisis occurring and to deal with any crises that do arise, and the implementation of these plans so as to minimize the impact of crisis and assist the organization to recover from them and restart its normal activities as quickly as possible. ([15], p. 3).

However, safety issues has been identified as among the major sources of crisis at rural tourism destinations $[6,11,14,16-19]$. Rural tourism projects in Nigeria of recent have been faced with multiplicity of crisis arising from safety issues. Poorly managed safety issues have given rise to high safety and risk perceptions among major actors in rural tourism projects in Nigeria and in some other sub-Saharan countries. This has sandwiched rural tourism projects in a 
crisis state with negative consequences on the sustainability of these tourism projects and investments. Untold consequences of crisis at rural tourist destinations in Nigeria are major concerns for the principal actors in this type of tourism. It discourages participation and involvement among these actors who may prefer to be alive and/or unembarrassed than engaging in an adventure or practice that may put his life or properties to avoidable risks. Suspension and/or refusal of rural tourism projects is a major blow for the socio-economic development of rural areas in Nigeria.

\section{The concept of three-way destination safety solution to crisis management (TWaDeSS model)}

Three-way destination safety solution otherwise known as TWaDeSS model is a new concept in destination management that is proposed for tackling crisis arising from safety issues at rural tourism destinations. This model is product of long-term field/research experience on rural tourism development in Nigeria. It is anchored on three variables of host community, tourism resources and tourists/visitors to guarantee sustainable crisis management in rural tourism destinations. The TWaDeSS model is expected to be conducted by the developer/investors at the various stages of the rural tourism project. The model has three major stages that are to be followed accordingly by the developers/investors of tourism projects in rural areas to yield expected positive results (Figure 1).

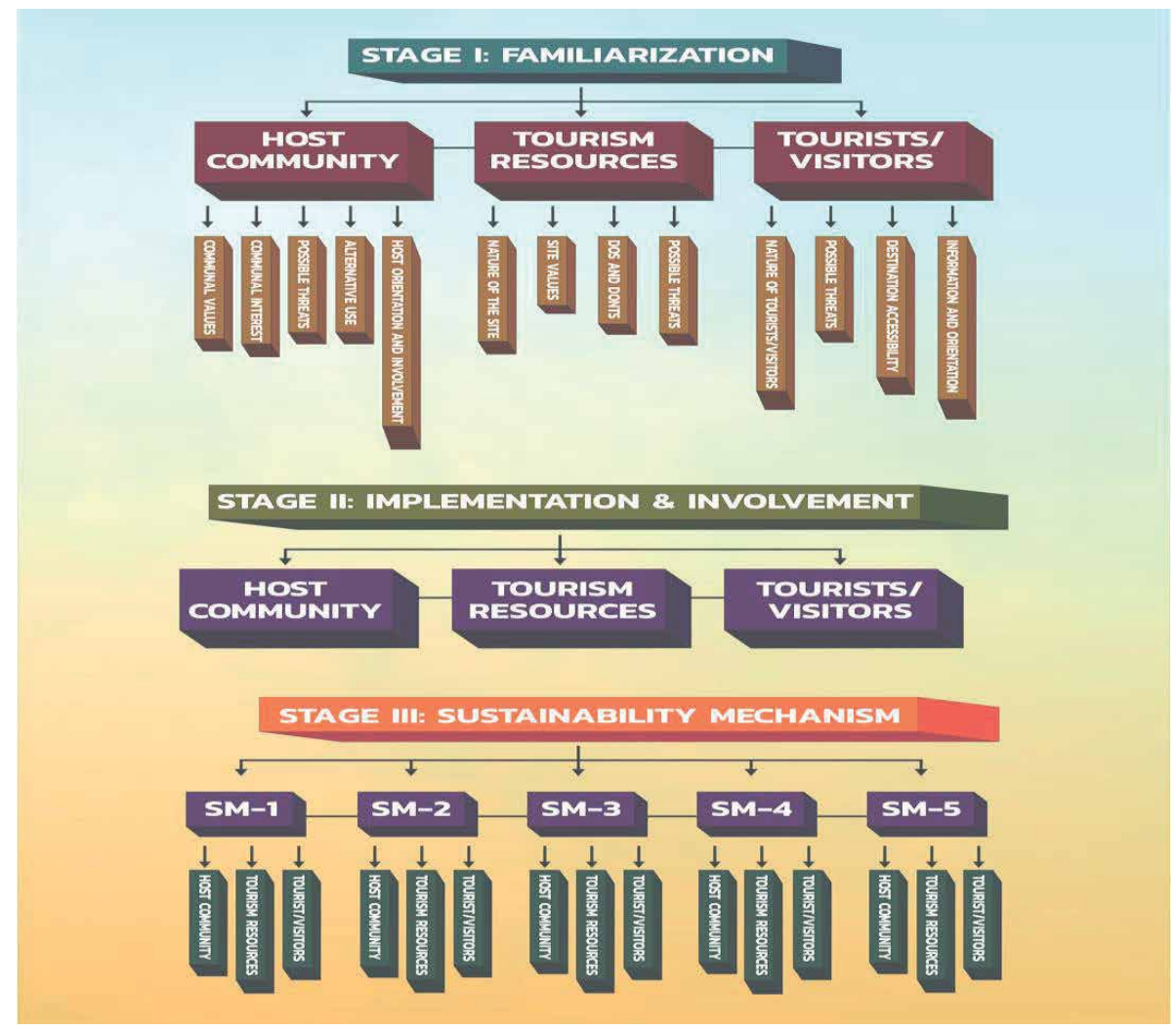

Figure 1.

The flow chart for TWaDeSS model and its application. 


\section{The structure and premise of TWaDeSS model}

Stage I: familiarization (pre-project execution). This has to do with sustained efforts to have a prior knowledge of the three principal actors in the tourism destination (host community, tourism resources and tourists/visitors) through provision of answers to some basic questions (Figure 2). The premise of TWaDeSS in this stage is anchored on the following variables and their basic questions:

a. Host Community: The following findings and considerations are necessary:

- Communal Values: what are the indigenous values of this community? What do they hold tenaciously in common since their inception?

- Communal Interest: what is their interest as a community with respect to the targeted tourism resources and rural development needs?

- Hazards from Tourists/Visitors: what are the possible hazards and other hazards that are likely to be experienced from the presence of tourists/visitors in their community? And how do you intend to handle such hazards on a long-term basis?

- Alternative Mechanisms: A close consideration would reveal that the targeted tourism resources serve one or more needs to the community. How do you intend to provide alternative sources to serve the need(s)? Would they appreciate or make do with the alternative provision?

- Orientation and Involvement: How do you inform them of the proposed projects? How do you get them involved in the proposed project? Would they be comfortable with the nature of their involvement?

b. Tourism Resources: The following findings and considerations are necessary:

- Nature of the Site: What is the historical background of the site? What is the expected carrying capacity of the site?

- Site Values: what is the primary and secondary value of the site to the host community? Does the site have any tourism value? Is the tourism value significant enough to merit tourism development initiatives? What is the nature of tourists/visitors the site is likely to attract?

- Dos and Don'ts: What are the dos and don'ts of the site? Can these dos and don'ts be managed if the site is developed? Are these dos and don'ts significant enough to deter possible site development for tourism schemes?

- Hazards/Threats: What are the possible hazards the site is likely to experience from visitors/tourists. How can this be checked if developed? What are the possible threats or hazards the site may likely experience from developers? And how can they be checked to guarantee sustainability of the site and the tourism project?

c. Tourists/Visitors: The following findings and consideration are necessary.

- Nature of Tourists/Visitors: What category of tourists/visitors is likely to be attracted to the site? What is the geographic and demographic characteristic 


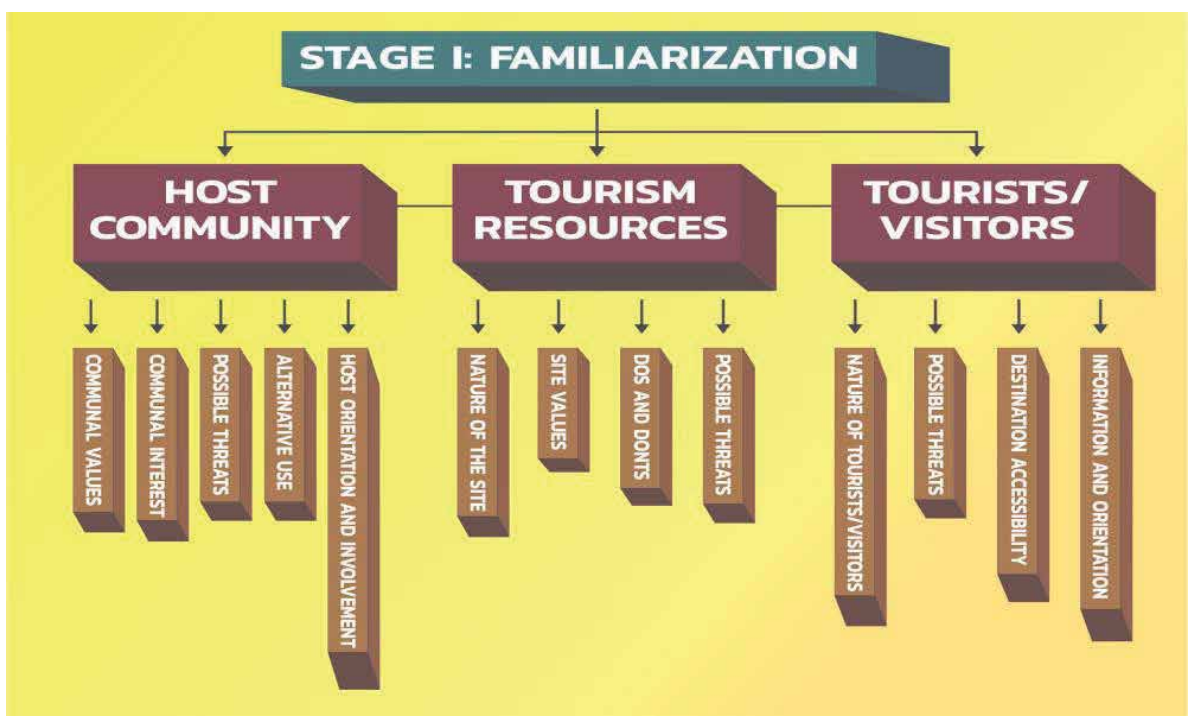

Figure 2.

Pre-project execution stage of TWaDeSS model.

of expected tourists/visitors? What are the possible attitudes of the expected tourists/visitors?

- Hazards/Threats: What are the possible threats or hazards tourists might face at the site? What are the possible threats tourists/visitors might face from the host community? What are the possible threats tourists visitors might face from the infrastructural and superstructural provisions at the site? Are there possible threats/hazards against tourists and visitors from people outside the community? How do you check these categories of threats?

- Destination Accessibility: How is tourists/visitors' access to information pertaining to the site like? What about physical access to the site? Are there encumbrances to physical access to the site? What is the friendlier medium for access to the site? What is the level of comfort on the site for tourists/ visitors as it concerns accessibility? Can tourists/visitors move alone or with guides in the destination?

- Information and Orientation: What is the necessary information the tourist/ visitor need to know about the site? How do you package the information? How do you put across the information? Will there be need for orientation programmes? How do you package the orientation to yield the needed result?

Stage II: implementation and involvement (project execution). In this stage, answers to basic questions are provided on how best to integrate these principal actors in the project implementation through involvement and other necessary considerations (Figure 3).

a. Host Community: What is the role of members of the host community in the project implementation? How can they get involved to achieve sustainable result?

b. Tourism Resources: With the prior knowledge of the tourism resources arising from the first stage, there is need to make necessary considerations on the 


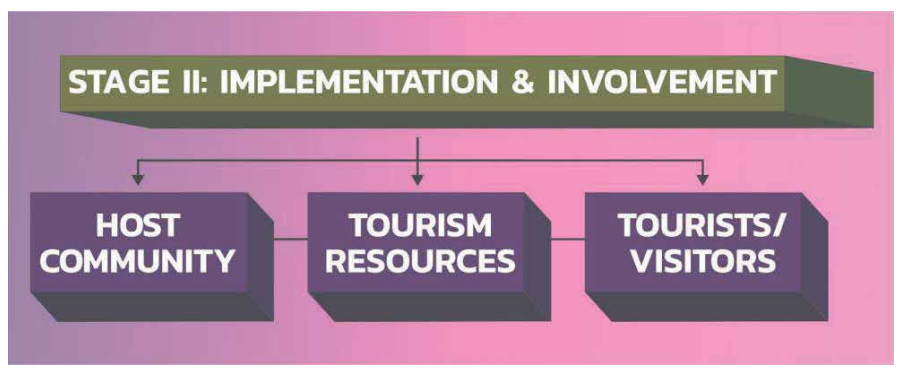

Figure 3.

Project execution stage of TWaDeSS model.

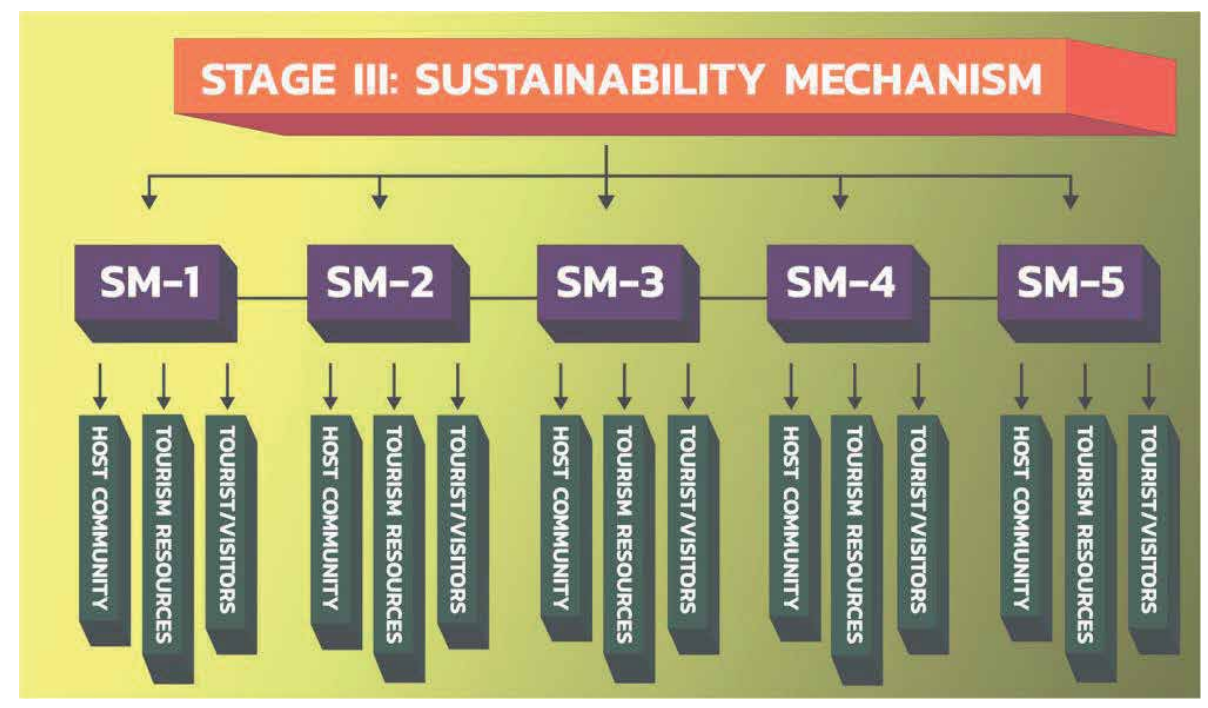

Figure 4.

Post-project execution stage of TWaDeSS model.

nature and value of the tourism resources during project implementation and involvement plans.

c. Tourists/Visitors: There is need to factor in the position and preference of the tourist/visitor during implementation to reduce the risk of wasteful investment.

Stage III: sustainability mechanism (post-project execution). This stage comes after the completion of the project, and the project is put to use. It targets the consolidation of the project towards ensuring its sustainability in the rural area. The five mechanisms are to focus on the three principal factors at the tourist destination (Figure 4). And the process is expected to be carefully followed from the first mechanism to the last mechanism. It has the following processes:

d.Sustainability Mechanism 1-Consultation and Opinion Gathering Mechanism (SM-1):

- Host community

- Tourism resources

- Tourists/visitors 
Consultation and opinion gathering mechanism is aimed at eliciting critical and genuine information on the existing project as it concerns the three principal factors with a view to evaluating the existing project in the subsequent mechanism.

e. Sustainability Mechanism 2-Evaluation and Feedback Mechanism (SM-2):

- Host community

- Tourism resources

- Tourists/visitors

Evaluation and feedback mechanism is targeted at evaluating the existing tourism project as it concerns the three principal actors and giving of feedback to guide future policy directions as it pertains to rural tourism projects in Nigeria and other developing nations.

f. Sustainability Mechanism 3-Restrategization and Consolidation Mechanism (SM-3):

- Host community

- Tourism resources

- Tourists/visitors

This mechanism which comes after the evaluation mechanism is focused on addressing the major concerns of the existing project as was revealed during the evaluation. This is done from the perspectives of the three principal factors in the tourist destination (host community, tourism resources and tourists/visitors).

g. Sustainable Mechanism 4-Future impact concerns (SM-4):

- Host community

- Tourism resources

- Tourists/visitors

This mechanism is focused on impact concerns of those identified strategies as they affect the three principal actors in the tourist destination. This is expected to give direction for the final mechanism which focuses on efforts to bridge the gap between these three principal actors and the tourism project in the rural area.

h.Sustainability Mechanism 5-Dialog and Orientation Mechanism (SM-5):

- Host community

- Tourism resources

- Tourists/visitors 
This mechanism is the last of them in stage 3 of TWaDeSS model. The emphasis of this mechanism is on how to maintain cordial relationship and tolerance among the three principal actors in tourist destination. This is expected to motivate the sustainability of the existing tourism project.

\section{Conclusion}

Safety threats, considerations, perceptions and expectations are the major stimulus for crises at rural tourism destinations. The understanding of this fact within the confines of the three principal actors in tourist destinations is among the responsibilities of investors and developers in rural tourism projects. TWaDeSS model is proposed in this study to manage these challenges at rural tourism destination with a view to maximizing the gains of rural tourism development to rural developments in Nigeria.

The technicality in the application of this model is that it demands great attention to details. Each of the stages of the model demands through consideration and application to yield expected results. Results from the previous stage inform the nature of the next stage. Also the model will be more useful in those rural communities with respected traditional authorities. Both public and private sector investments in rural tourism projects have to understand these technicalities to have a good return on investment. The periodic use and/or involvement of stakeholders and/or constituted management committees is highly recommended; hence it will aid in establishing tolerance and coexistence among these principal actors to manage upsurge of destination crisis at the rural tourism destinations.

Efforts have been made to propose a viable model in this work to enhance the gains of rural tourism initiatives to rural development in Nigeria and some other subSaharan countries. Application of this model to other situations and constructive critiques would strengthen the depth of the model in rural tourism development. Each stage of this TWaDeSS model is critical and significant in sustainable crisis management at tourist destinations. It is however the principal responsibility of the developers/planners of tourism projects to follow these stages to completely eradicate crisis at tourist destinations or reduce the occurrence to the barest minimum.

\section{Author details}

Elochukwu A. Nwankwo

Department of Archaeology and Tourism, University of Nigeria, Nsukka, Nigeria

*Address all correspondence to: elochukwu.nwankwo@unn.edu.ng

IntechOpen

(C) 2019 The Author(s). Licensee IntechOpen. This chapter is distributed under the terms of the Creative Commons Attribution License (http://creativecommons.org/licenses/ by/3.0), which permits unrestricted use, distribution, and reproduction in any medium, provided the original work is properly cited. (cc) BY 


\section{References}

[1] Mclntosh RW, Goeldner CR. Tourism: Principles, Practices and Philosophies. New York: Wiley; 1990

[2] Dann G. Anomie, ego-enhancement and tourism. Annals of Tourism Research. 1977;4(4):184-194

[3] Gnoth J. Tourism motivation and expectation formation. Annals of Tourism Research. 1977;24(2):283-304

[4] Haldar P. Rural tourism: challenges and opportunities. In: International Marketing Conference on Marketing and Society 8-10th April 2007. Kerala: Indian Institute of Management Kozhikode; 2007. pp. 11-129

[5] Romera EB, Brida GJ, Martnez CA, Riano E, Devesa MJS. Rural tourism at Arqitectura Negra villages (Guadalajara, Spain): Demand analysis. Tourism Management. 2011;27:1011-1013

[6] Nwankwo EA, Agboeze MU, Nwobi AU. Community heritage resources and crisis management in rural Nigeria. SAGE Open. 2018;8(2):1-15

[7] Tsephe NP, Obono SDE. A theoretical framework for rural tourism motivation factors. International Journal of Economics and Management Engineering. 2013;7(1):273-278

[8] Alyward E. Rural tourism development: Proposing an integrated model of rural stakeholder network relationships. In: 2009 IAM Conference at Galway Mayo Institute of Technology 2nd-4th September. 2009

[9] Mannell R, Iso-Ahola S. Psychological nature of leisure and tourism experience. Annals of Tourism Research. 1987;14:314-331

[10] Basher M, Ajloni AA. Motivating foreign tourists to visit the rural site in Jordan, village of Petra. Australian
Journal of Business and Management Research. 2012;2(5):1-7

[11] Ayob NM, Masron T. Issues of safety and security: New challenging to Malaysia tourism industry. SHS Web of Conferences. 2014;12(01083):1-10

[12] Freyer WA. Tourism and terrorism: An analytical framework with special focus on the media. In: Laws B, Prideaux B, editors. Crisis Management in Tourism. Oxon: CAB International; 2007. pp. 129-141

[13] Popescu L. Safety and security in tourism case study: Romania. Forum Geografic. 2011;10(2):322-328

[14] Obieluem UH, Anozie OO, Nwankwo EA. A study on safety and security issues at selected tourist sites in eastern Nigeria. International Journal of Research in Arts and Social Sciences (IJRASS). 2016;9(1):66-77

[15] Colpofer. Recommendations for crisis management. Paris: UIC Additional Global security program; 2017

[16] Hasan K, Ismail AR, Islam F. Tourist risk perceptions and revisit intention. A critical review of literature. Cogent Business and Management. 2017;4(1412874):1-21

[17] Wong J, Yeh C. Tourist hesitation in destination decision making. Annals of Tourism Research. 2009;36(1):6-23

[18] Wu BH, Wang X, Li MM. Chinese college students perceive the evaluation of tourism security research. Journal of Guilin Institute of Tourism. 2001;12(3):62-68

[19] Zhang JK. Optimization and empirical model of tourism risk perception. Journal of Tibet National Institute (Philosophy of Social Science). 2012;33(2):45-48 



\title{
Crisis Management in Nigeria's Public Sector and the Impact of the Organised Labour Union: Interrogating the Nexus between Industrial Harmony and Political Stability
}

\author{
Daniel Taye Medoye
}

\begin{abstract}
This study sought to explore the dynamics in managing crisis in the Nigerian public sector and its engagement with the organised labour, with a view to determining the interface between industrial harmony and political stability in the country. This study is predicated on the fact that crisis management is essentially embedded in humanity. Additionally, the study was informed by the established and widely held view by scholars, that social groups by their nature and context, are in fact characterised by conflicts. Consequently, the study established that the public sector in every society is not immune against conflict or crisis, and this will naturally arise as long as there is interaction between and among human elements in the two sectors. The author used the terms_crisis and conflict-interchangeably in the study, and pointed out that the methodology adopted was a descriptive and analytical approach. This is informed by the sources of information accessed which are essentially secondary. The study concluded by asserting that given the humanity-linked nature of conflict, its management in the public sector, particularly in Nigeria, will continue to be an unavoidable responsibility of the government. This is to ensure that the right environment is created to guarantee smooth governance.
\end{abstract}

Keywords: crisis/conflict management, organised labour union, industrial harmony, political stability, strikes and collective bargaining

\section{Introduction}

This study seeks to interrogate the nexus between industrial harmony and political stability as a potential determinant or otherwise, in crisis management, and this will be undertaken within the context of the Nigeria's public sector and its interface with the organised labour. This study further seeks to provoke insightful discussions around the commonplace crisis management mechanisms such as mediation, conciliation and arbitration, otherwise described as alternative disputes resolution (ADR), with view to determining and attaining more strategic and proactive ways 
of ensuring a harmonious working relationships between the government and its workers on one hand, and between organisations in the private sector and their employees. This study is predicated on the fact that crisis management is essentially embedded in humanity. In the opinion of some writers, social groups by their nature and context, are in fact characterised by conflicts. This is so because aims, objectives and interests of the social units or individuals that constitute any social groups (including labour unions) differ.

According to Dontigney [1], any situation involving more than one person, conflict can arise. In his view, the causes of conflict range from philosophical differences and divergent goals to power imbalances. Dontigney [1] however warns that unmanaged or poorly managed conflicts has the tendency to generate a breakdown in trust and lost productivity. By extrapolation, this viewpoint can equally be validated in the context of public sector crisis management in relation to the impact of the organised labour unionism. This is unavoidable given the fact that both the government and the labour organisation are structurally antithetical in terms of objectives and functions. However, both will not operate in isolation but will continue to engage and synergise to create and advance industrial harmony which is a sine qua non to stability.

In doing this, it will be worthwhile to contextualise the scope of the study by providing a description of the variables associated with the focus of the study.

The public-sector is a combination of two words which can generically, be described as comprising the exclusive administrative space where the government serves as the employer at the federal; state (provincial or regional) and local (municipal or county) government levels, depending on the nomenclatures adopted by each sovereign country [2]. It also comprises state-owned companies and parastatals, so created to carry out assigned responsibilities for the purpose of serving the entire citizens of the country by the provision of basic services constitutionally guaranteed. These levels of government and the agencies are manned by different cadres of personnel, and who engage in discharging their respective assignments. On the other hand, the organised labour organisations represent exclusively, representatives of a defined group of employees which are concerned with the negotiation, administration, interpretation and enforcement of written agreements covering joint understanding as to wages/salaries, rates of pay, hours of work and other conditions of employment. Simply put, labour organisations The public service refers to the amalgamation of services provided by government to people living within its jurisdiction, either directly (through the public sector) or by financing provision of services. In other words, service provided or supported by government or its agencies as embedded in the constitution of the state or country. The partial provision of such or total neglect has resulted in series of socio-economic and political upheavals in countries thereby disrupting governance and usually accompanied by instability.

\section{Study research questions}

Against the author's concerns and interest as expressed in the introductory section above, this study seeks to provide objective, but somewhat provocative responses to the following questions which include:

a. What is the nature of the public sector crisis in Nigeria, and what are the immediate and remote factors responsible for it?

b. What is the nexus between industrial harmony and political stability in Nigeria? 
c. What mechanism(s) does the Nigerian government adopt in managing and resolving the crisis between the state and the organised labour?

d.What policy option can the explored to strengthen the nexus between industrial harmony and political stability towards effective governance?

These questions will be responded to and addressed in the study.

\section{Methodology}

The study is literature based, and this involves engaging relevant sources from which to draw a basis and strength for its eventual outcomes, particularly from previous related publications and write-ups. This is inevitable since the information to be deployed is essentially from secondary sources, but will be critically examined. In doing this, the author will consider a literature survey method to establish the relevant issues at stake in the context of this paper, and will accordingly do so in the course of the write-up. Furthermore, identified themes and findings therefrom will be critically examined with a view to arriving at fresh perspectives on how the creation of industrial harmony or otherwise, by the organised labour will conduce to a desirable political environment in Nigeria, on one hand, and to serve as a mechanism of crisis management in the public-sector in particular, and in the society in general. This paper proceeds by identifying the relevant theoretical framework for the study. This is followed with a rehash of the nature, evolution and the operations of the organised labour unionism in Nigeria and will attempt to point out its impact on governance dynamics in the country. The paper will provide insights into the character of the private sector where the government dictates the pace, thereby exposing the nature of the relationship that exists between the government and its employees, who are part of the organised labour.

\section{Theoretical framework}

The author seeks to apply the conflict theory as the theoretical framework, among the other relevant theories, to underpin the study which focuses on highlighting the nexus between industrial harmony and political stability in the context of crisis management in Nigeria's public sector. The is consequent upon the acute relevance of the theory to the focus of the study which has to do with management of crisis and the fact that conflict is recognised and acknowledged as a part of humanity. According to Chidi and Okpala [3], 'conflict theory is synonymous with the pluralist or the pluralistic frame of reference'. In their view, the conflict theory sees the organisation as a coalescence of sectional groups with different values, interests and objectives. Thus, employees have different values and aspirations from those of management, and these values and aspirations are always in conflict with those of management. The two scholars contend that Conflict theorists argue that conflict is inevitable, rational, functional and normal situation in organisations, which is resolved through compromise and agreement or collective bargaining. Conflict theorists view trade unions as legitimate challenges to managerial rule or prerogatives and emphasise competition and collaboration. This view recognises trade unions as legitimate representative organisations which enable groups of employees to influence management decisions [4] Rose.

Rose further states that the pluralist perspective would seem to be much more relevant than the unitary perspective in the analysis of industrial relations in many 
large unionised organisations and congruent with developments in contemporary society. In the opinion of Wokoma [5], the conflict theory evolved from the works and ideas of Karl Marx, who contended that conflict is inevitable and stems from inequalities of power and economic wealth inherent in a capitalist economy or society. It should be noted that this study is not intended to view the issues associated with this study from any ideological perspective, but strictly from an academic and analytical prism.

The relevance of this theory derives from the role of theoretical construction in research which, in the view of Badejo [6], serves to observe, understand, explain, predict and control events or phenomena. For Fajana [7], theory 'helps in our understanding of events and problems in the practical world'. By application therefore, the fact of the conflict nature of social groups, such as the organised labour being a coalescence of individual group of people, suggest the inevitability of disagreement in the course of interactions that could lead to conflict or crisis from time to time. Therefore, the conflict theory would be most appropriate to underpin this study.

\section{Crisis management in public-sector: Literature survey}

As indicated earlier, this author reiterates that crisis will naturally exist in every given society of human beings in interactions. So also will there be conflict or crisis in every sector, unit or platform which consists of human beings in interactions. The Nigerian public sector is not immune from this phenomenon. What is important is that steps are taken to address any conflictual or crisis-ridden situation. Given the context of this study, it is relevant to highlight the place of government (the State), being the machinery upon which the entire governance responsibility for the country rests. This section will involve some literature survey of previous studies which have dealt with industrial or employee relations in Nigeria and how such has fared under the government.

\subsection{The role of the state in public sector crisis management}

According to Badejo [6], 'the state had traditionally played various roles in different countries, most especially in providing the institutional framework for the bilateral relationship between workers/Trade Union and Employers/ their representatives to encourage a bipartite relationship'. This suggests that the government, whether at the national, provincial, regional or local level, serves to create and regulate the work environment in terms of legislations which prescribe how workers can conduct their affairs in their working relationship with government. Badejo [6] further mentioned about the government's publication of the National Labour Policy in 1975, which contained its direct intervention and the pursuance of guided democracy in labour matters, and this involved limited intervention in certain areas of labour activity in order to guarantee industrial harmony.

Expectedly, the government has not ceased from continuous intervention and interference in virtually every area of industrial relations. In the case of Nigeria, such interference has resulted into disruptive strike actions that have in most cases, caused socio-economic and political paralysis in the country. In such circumstances, governance has ultimately borne the brunt as the country would have been engulfed in disorderliness, thereby manifesting in grave security threats. However, scholars like Ubeku [8], believe that there are reasons for state intervention in trying to regulate activities of organised labour. 
According to Ubeku [8] in particular, such reasons include among other things, the overwhelming position of government as an employer of labour; political and economic considerations; historical and international imperatives, etc. In the opinion of Otobo [9], whose analysis appears more specific than as highlighted by Ubeku [8], the state (government) unavoidably intervenes in industrial relations matters as a result of it being a huge employer of labour, hence, employment and manpower development structuring; regulations of wages and salaries; union government and administration; collective bargaining; and industrial conflict [9]. However, the position of Yesufu [10] in the classification of the role of government offers clearer perspectives, and will be deployed in this study.

According to Yesufu [10], the role of government in its dealings with the Nigerian labour movement consists of-leadership role; legislative and regulatory role; investigatory and advisory; education and training; and adjudicatory.

On leadership, Yesufu [10] observes that the responsibilities of the state involves economic development and improvement in the standard of living of the people. Consequently, the position of government as the major single largest of labour and as guardian of the social conscience, places the state in a peculiar position to provide leadership in industrial relations as in all other fields of economic and social endeavour. Yesufu [10] argues that this role should necessarily be concerned with the manifestation of policies and by setting the examples though the remuneration and compensation policies. From this vantage position, it could be said that the government exists to serve the interests of every citizen of the country, including that of labour.

At the level of legislative and regulatory responsibility, Yesufu [10] reveals that the role of the state is carried out mainly through the enactment and enforcement of labour and industrial relations legislation which ensures minimum basic and acceptable standards of employment, condition of work, welfare and security, and the institutional framework for the conduct of industrial relations. This suggests that the state, given its sovereign status, possesses the mandate to provide the rules and regulations by which citizens and institutions of government can and should conduct their affairs and relationships within defined confines.

At the level of investigatory and advisory responsibility, Yesufu [10] believes that these functions of the state are generally undertaken by the Federal Ministry of Labour. In the case of Nigeria, it is Ministry of Labour and Employment, and the mandate derives from the ministry's role in the enforcement of the various labour laws and policies. Operationally, the ministry is expected to constantly engage in touring employment establishments under its jurisdiction in order to ensure conformity with labour and industrial relations legislation, investigating breaches and grievances, and generally advising employers on improvements in working conditions and on management/employee relations.

On education and training responsibility, Yesufu [10] believes and argues that it is expected of the state to provide the environment which conduces to education and training of its employees on their duties and obligations as public servants. This way, it is believed that a thorough education will help solve most of the industrial relations problems in the developing countries.

On adjudicatory role of government, Yesufu [10] is of the opinion that, in spite of how much enlightened an industrial or employee relations system may be, there are constant labour grievances, misunderstandings and disputes which need to be settled. The state accordingly provides machinery for intervention and settlement in such cases, particularly in regard to collective disputes, through the appointment of conciliators, arbitrators, and the establishment of industrial relation courts.

From the foregoing, it is evident that the state does have clearly defined role to play to create the environment for a favourable industrial relations, where 
employees can be assured of their welfare and the promotion of same. Viewed critically, it is the suggestion of this author that this position of the government could not have been avoided. This role cannot be undermined regardless of the nature of government. However, the scenarios under military regimes have proved otherwise, and this much was characteristic of the Nigeria's experience under the military dictatorship. The 1994 experience when the late dictator descended heavily on the labour organisations for daring to intrude into matters considered a 'no go area', and the consequences are better imagined. However, this paper will point out if the status can be rejigged for fairness, and that will be towards the conclusion of the write-up.

\subsection{The nature and character of the organised labour in Nigeria}

Historically, trade unionism is recorded and believed to have begun in Nigeria in 1912, when government employees in the public service (public sector) formed the Nigerian Civil Service Union (NCSU), an organisation of workers to promote the interest and welfare of its members in relation to conditions of service [11]. However, the passing of the Trades Union Ordinance in 1938 by the then colonial government provided the legal basis for the existence of labour organisations in the country. The ordinance stipulated the rights and privileges, and the conditions under which the union could safely operate. It is noteworthy that overtime, since the coming into effect of the ordinance, several labour organisations have sprung up in the country with virtually workers in every government department-from national to local-covered under one union or the other.

Perhaps, it is worthwhile to clarify from the onset that industrial harmony, in the context of this chapter, refers to the creation and sustenance of a conducive work environment which results from the deliberate efforts by both representatives of employers and employees. This view can be predicated on the position of Chidi and Okpala [3], who are of the opinion that the interactions between the employers and employees in relations to a work environment, are based upon the determination of substantive and procedural issues at industrial, organisational and workplace levels. It is also arguable that industrial harmony encompasses industrial relations or employee relations which consist of the relations that exist between individuals or groups of employees and employers who engage themselves in a way to maximise the productive activities.

According to Tar [12], the 'Nigeria labour movement is often described as the veteran of democratic struggle in the country'. By this description, it is believed that the Nigeria labour movement has come to be regarded as the triggers to the struggles and agitations against government, particularly the military rule which has held sway in the country more than democratic government. Labours' experience is such that the organised unions had to contend with stiff repression from the state under a military rule, which does not consider human rights violations as an aberration. Tar emphasised that, the history of Trade Union movement in Nigeria and elsewhere is closely knit with the struggles for democratic values such as human rights, welfare, wage, equal franchise. Tar however acknowledged that, because of its ideological stance as the defender of workers' right, the labour movement is often neglected when it comes to discourses on democratic struggles. This view about the vibrancy and potency of labour unionism in Nigeria and how the it has engaged with the government on issues of workers welfare in relation to the upholding and promotion of human rights is not far-fetched. This is despite the repressive tendencies of the government aimed at silencing the actions (such as demonstrations, protests and ultimately strikes) of the unions which are seen as irritable and capable of making governance impossible. Perhaps, it should be mentioned that 
the role of labour goes beyond agitations for improved welfare for its members to include intensified advocacy for democracy and its associated values. This view can be predicated on the position of the International Labour Organisation (ILO), as can be seen in its report in 1998. According to the ILO, unions play important role in guiding and upholding democracy and as defenders of social justice, in particular, by encompassing women, minorities, consumer groups, the unemployed and the growing ranks of working poor in the sphere of action, ILO [13]. Ironically, this position seems to run counter to the interest of government, particularly the military regime, which considers that as a threat. Regardless of how labour movement is viewed, trade unions or labour organisations will continue to be in the forefront of the yearnings for industrial democracy, otherwise, known as workers participation in the management of their enterprise.

It might be necessary to mention and highlight the real interest of the organised labour as it seeks to represents its workers so as to be able to identify at what point such interest collides with the running of government, which is a significant element being considered in this study.

However, the question to be raised at this point is, - to what extent should the state be involved in Industrial Relations or Employee Relations in the context of the Nigerian public sector? According to Badejo [6], the role ascribed to the state in industrial relations depends on the ideological bent of the state. Badejo [6] observes that in communist countries, no separate role is envisaged for employers and trade unions, but that they operate on the basis of party directive and the state plan. This is in contrast to the capitalist countries, where the approach is to allow employers and unions reasonable latitude to determine their own affairs within the framework established by the state. The developing countries, as a result of their experience have had to intervene in industrial relations in the interest of the whole economy.

However, as the state is the prime mover of the total social system, there is no argument as to whether it has a role to play or not. The reason for state intervention under could be considered from the following perspectives-economic; historical and international imperatives; the states dominance as an employer of labour; political and social. Otobo [9] noted five areas most frequently subjected to state regulations, namely employment and manpower development; wages and salaries; union government and administration; collective bargaining; and industrial conflict.

Against the background of the inevitability of conflict which results from discord that occurs when the goals, interest or values of different individuals or groups in an industrial setting are incompatible, it is relevant to identify in a strict sense, the immediate factors that often trigger labour union's resistance that most times turns out disruptive. For the purpose of this study, these factors will be pin-pointed and they include, among others-government' refusal or unwillingness to recognise labour or trade unions, public policies which are perceived anti-citizens, failure of collective bargaining as a result of hard stance positions, and outright repression of dissenting opinions.

In Nigeria, these issues have led to several strike actions and protests, and have resulted in government coming to a standstill in a lot of the occasions. For example, the Nigerian Labour Congress (NLC), and the Trade Union Congress (TUC), had declared a strike in 2019, following months of failed discussions with the government on working conditions and minimum wage. The strike adversely affected the administrative and commercial capital of Abuja and Lagos respectively as government complexes were locked, thus crippling public and civil service across Africa's most populous nation. Similar strikes have taken place, particularly during the military rule which does not respect the fundamental human rights of the people and rule of law. While it is acknowledged that this study is not about strikes and protests, it is necessary to point out that they serve as a means 
by which labour unions cause disruptions in the economy of a country thereby engendering an atmosphere of instability.

\section{Mechanisms for resolving public sector crisis by government and labour}

Conflict resolution mechanisms may differ from organisation to organisation but there are established strategies that have been in use. Whether in private or public sector, the following can be said to be the evolving methods of conflict resolution. These strategies include mediation, conciliation and arbitration. These are referred to as alternate disputes resolution (ADR) mechanisms deployed by disputants, and who are willing to abide by settlement terms. Experience has shown that disputing parties use these ADR methods because they are relatively expeditious, private, and generally much less expensive than resorting to the courts.

The use of any of these methods involves some form of bargaining, commonly referred to as collective bargaining (CB). As a concept, Rose [4] reports that the term was originated by Webb and Webb to describe the process of agreeing terms and conditions of employment when the representatives of employers, and that of the employees. Rose [4] explains that CB could also be defined as a process whereby representatives of employers and employees jointly determine and regulate decisions pertaining to both substantive and procedural matters within the employment relationship.

In the Nigerian public sector, crisis emanating from industrial disputes of serious magnitude, has been subjected to the collective bargaining process. For example, crisis triggered by national strikes that had the tendency to constitute security threats to the government, has had to be resolved through a collective bargaining process. The challenge in this is that the place and role of the state, in most cases, tend to vitiate the effectiveness of this process. This aligns with the view of Adebisi [14], who lamented the highhandedness of the Nigerian government in respect of labour matter for making a nonsense of these mechanisms or procedures for dispute settlement. More often than not, the Nigerian government fails to honour its own agreement with labour, thereby setting poor standards for employers in the private sector. Violations of agreements reached through collective bargaining process have occurred more during the military regime(s) in Nigeria. It is on record, and clearly too, that the military has violated more agreement reached out of collective bargaining than constitutional democracy in Nigeria or the world over. In this instance, Adebisi [14] has cited the failure or reluctance of government to honour a number of agreements with the Academic Staff Union of Universities, ASUU, and the Nigerian Labour Congress, NLC. The current federal government of Nigeria is in the midst of reaching agreement with the organised labour in respect of minimum wage over which there had been disruptive strike actions which had occasioned security nightmares all over the country.

The interesting thing about the adoption of the collective bargaining process as a mechanism for resolving labour issues in Nigeria appears to be the only means possible hitherto. This is not to prejudice the possibility of either improving on the process for more effective operation or exploring additional measures that will complement the process.

At this point, and by way of digression, it is necessary to mention that there are conflict resolution mechanisms peculiar to the private sector. This applies to small businesses, where success often depends or rests on the cohesion of a few people, the loss of trust and productivity can be a challenge to the continued existence and growth of the business. For such businesses, it will be helpful to rely on the prescriptions of Dontigney [1] who had identified the following conflict management 
strategies that can be deployed in addressing conflictual relationships. These include-accommodating strategy which essentially entails giving the opposing side what it wants. The use of this strategy occurs when one of the parties wishes to keep the peace or perceives the issue as insignificant; the avoidance strategy, which seeks to put off conflict indefinitely. The mechanism hopes the problem resolves itself without a confrontation; the collaboration strategy works by integrating ideas set out by multiple people. This method is deployed to find a creative solution acceptable to everyone; the compromising strategy is used when parties to a conflict may have to give up elements of their position in order to establish an acceptable solution. This strategy applies in conflicts where the parties hold approximately equivalent power; and lastly, the competition strategy operates in a situation where one side to a conflict wins and other loses. This is also referred to as a zero-sum game. In politics, such is described as winner takes all.

\section{Industrial harmony and political stability: Any nexus?}

To be able to provide a rational and an objective response to this question, it is necessary to aggregate the elements that constitute industrial harmony and political stability by drawing from the insights on the terms as highlighted in the foregoing. As indicated earlier in this study, since the relationship between the government and the labour organisation are structurally antithetical in terms of objectives and functions it is therefore unavoidable that there will always be frictions from time to time as both sides seek to achieve their aims and objectives. But for the sake of peace and stability, it is expected that both sides will continue to engage and synergise to create and advance industrial harmony, a sine qua non to stability, to ultimately provide a conducive environment for governance. Ensuring peace and stability will facilitate the discharge of the world-wide constitutional responsibility to governments in terms of provision of security and welfare for the citizens.

Consequently, the following themes can be identified and posited:

- That crisis/conflict in human interactions is inevitable;

- That industrial harmony and political stability are two inseparable phenomena;

- That the former (industrial harmony) is a sine qua non for the latter political stability;

- That both conditions can be facilitated by the state (government) and labour organisations;

- That there exists a link (nexus) between industrial harmony and political stability.

This study is inclined to observe that industrial disputes, if poorly managed or not addressed, will ultimately lead to protests, demonstrations and strikes. Workers, worldwide have always resorted to strike actions when the sides to disputes fail to reach mutual agreement. In the case of the public sector crisis, where the Nigerian industrial relations system today to be replete with cases of violations of negotiated agreements as a result of executive lawlessness, the resort to strike actions by workers, usually organised and called by the organised (central) labour organisation seems to have been institutionalised. 


\section{Matching of themes to research questions (discussion of findings)}

In this section, the author proceeds to relate the identified themes which emerged in the course of literature survey on what constitutes industrial harmony and political stability and to answer the question if there is a nexus between the former and the latter in the context of the Nigerian public sector crisis management.

In response to the research question a, of this study which is concerned about the nature of public sector crisis in Nigeria, and what constitutes the immediate and remote factors responsible for it, the author argues that crisis management is essentially embedded in humanity. This is so because social groups by their nature and context are characterised by conflicts. In addition, it is arguable that because aims, objectives and interests of the social units or individuals that constitute any social groups (including labour unions) differ, conflict or crisis will inevitably occur. This view has not been emphasised by authors, some of whose works were cited in this study, but has remained valid at all material time.

On research question $b$, which is concerned with the nexus between industrial harmony and political stability in Nigeria, it is the opinion of the author that, given the fact of the inevitability of frictions between labour unions and the state as has been established and acknowledged by scholars cited in this study on one hand, and the aftermath of the disruptions which result therefrom on the other hand, it is no longer far-fetched that there exists a connection between industrial harmony and political stability. As noted earlier in the study, the author believes that for the sake of peace and stability, it is expected that both sides (the State and Labour) will continue to engage and synergise to create and advance industrial harmony, which will ultimately lead to a conducive environment for governance.

On study research question c, which relates to what mechanism(s) the Nigerian government can adopt in managing and resolving the crisis between the state and the organised labour, the author believes in the efficacy of the collective bargaining process, but will argue that these can be complemented with the alternative disputes (conflict/crisis) resolution mechanisms, which include mediation, conciliation and arbitration, be deployed exhaustively, coupled with the readiness of parties to disputes to accept resolutions adjudged to be fair and just.

In relation to the study research question $d$, which relates to the policy option that can be explored to strengthen the nexus between industrial harmony and political stability towards effective governance, the author will make reference to the existing method of engagement between government and labour in terms of the term collective bargaining process to resolve disputes, and suggest the following policy directions which include, that -

- The mechanism of collective bargaining mechanism be retained;

- Stakeholders involved in collective bargaining demonstrate greater transparency and willingness for tolerable compromises;

- The government should be conscious of its responsibility to the entire citizens of the country in terms of security and welfare, by ensuring good governance and responsible leadership;

- The government, being the largest employer of public servants and its role of regulation and adjudication, does show unbiased commitment to respecting terms of agreements reached during negotiations. 


\section{Conclusion and recommendations}

So far, attempts have been made in this study to reflect on crisis management in the Nigeria public sector in relation to the link between industrial harmony and political stability. The study sought to determine if there exists a nexus in-between industrial harmony and political stability, and proceeded to describe the variables identifiable and as conceived for the study. The study prescribed the applicable theoretical framework deployed to underpin the research, and carried out considerable survey of relevant literature from which information needed to contextualise the focus envisaged.

In this study, the author found out that, given the humanity-linked nature of conflict, its management in the public sector, particularly in Nigeria will continue to be an unavoidable responsibility of the government. The author contends that this is not just a necessity, but a must-activity to ensure that the right environment is created to guarantee smooth governance. Consequently, the study conclusively remarks and recommends the following:

- That crisis or conflict as a phenomenon, will continue to exist in human society but that its management, in terms of resolution mechanisms, can be improved for positive impact;

- That the Nigerian public sector crisis management approach will improve and has been given the deepening of democratic institutions and practice which conduces to friendly employee and industrial relations;

- That all stakeholders to the mechanism of collective bargaining process should endeavour to be transparent and committed to terms of agreement to avoid the tendency to any form frictions that could spark crisis; and finally,

- That organised labour organisations should evolve, promote and implement sound policy on education and training of their members to imbibe the culture of tolerance and extreme understanding in responding to policy decisions of government, to guarantee positive interface.

\section{Author details}

Daniel Taye Medoye

International Relations, International and Public Affairs Clusters, School of Social

Sciences, University of KwaZulu-Natal, Scottsville, South Africa

*Address all correspondence to: tayemedoye@gmail.com;

tayemedoye@yahoo.co.uk; daniel.medoye@gmail.com

\section{IntechOpen}

(C) 2020 The Author(s). Licensee IntechOpen. This chapter is distributed under the terms of the Creative Commons Attribution License (http://creativecommons.org/licenses/ by/3.0), which permits unrestricted use, distribution, and reproduction in any medium, provided the original work is properly cited. (cc) BY 


\section{References}

[1] Dontigney E. 5 Conflict Management Strategies. 2018. Available from: http:// smallbusiness.chron.com/5-conflictmanagement-strategies-16131.html

[2] Francis AC, Tunde E, Gbajumo-Sheriff MA. Collective Bargaining Dynamics in the Nigerian Public and Private Sector. 2011. Available from: https://www.yumpu. com/en/document/read/28924749/ collective-bargaining-dynamics-in-thenigerian-public-and-private

[3] Chidi CO, Okpala OP. Theoretical Approaches to Employment and Industrial Relations: A Comparison of Subsisting Orthodoxies. 2012. Available from: https://www.intechopen.com/ books/theoretical-and-methodologicalapproaches-to-social-sciencesand-knowledge-management/ theoretical-approaches-to-employmentand-industrial-relations-a-comparisonof-subsisting-orthodoxies

[4] Rose ED. Employment Relations. 3rd ed. London: Pearson Education Ltd; 2008

[5] Wokoma CU. The Effects of Industrial Conflicts and Strikes in Nigeria: A Socio-Economic Analysis. 2011. Available from: https://www. ajol.info/index.php/ijdmr/article/ view/66976

[6] Badejo AE. A Critique of the Role of the State in Industrial Relations in Nigeria. 2011. Available from: https:// pdfs.semanticscholar.org/52e2/7d306512 229604c0a97c605a4dee267070b1.pdf

[7] Fajana SA. Industrial Relations in Nigeria: Theories and Features Lagos. Labofin and Co; 2000. Available from: https://www.ilo.org/wcmsp5/groups/ public/---ed_dialogue/---sector/ documents/publication/wcms_161189.pdf
[8] Ubeku AK. The role of the state in industrial relations. In: Damachi UG, Fashoyin T, editors. Contemporary Problems in Nigerian Industrial Relations. Lagos: Development Press; 1986

[9] Otobo D. Industrial Relations: Theory and Controversies. Lagos: Malthouse Press Ltd.; 2000

[10] Yesufu TM. The Dynamics of Industrial Relations: The Nigerian Experience. Ibadan, Nigeria: University Press Ltd; 1982. Available from: https://search.library.utoronto.ca/ details?2103760\&uuid=88e3d5a7-06584c6e-a493-a4143f5c26c2

[11] Egboh EO. Trade Union in Nigeria. African Studies. 2007;27(1):35-40. DOI: $10.1080 / 00020186808707272$

[12] Tar UA. Organised Labour and Democratic Struggles in Nigeria. 2009. Available from: https://core.ac.uk/ download/pdf/36771587.pdf

[13] ILO. World labour report 1997-1998, International Labour Organization. In: Adefolaju T, editor. 2013, Trade Unions in Nigeria and the Challenge of Internal Democracy. 1998. Available from: https://www.mcser.org/journal/index. php/mjss/article/view/288/304

[14] Adebisi MA. History and development of industrial relations. In: Nigeria: Hybridity of Western Models Versus Military Interventionism Culture. 2013. Available from: https:// www.mcser.org/journal/index.php/ mjss/article/view/1652/0 
Section 3

\section{Applied Aspects of Crisis Management for National Security and Law Enforcement}





\title{
The Police Development and Protection of Soft Targets
}

\author{
Martin Hrinko, David Palička, Leoš Hájek and Petr Kubický
}

\begin{abstract}
This paper describes the function and development of the requirements for modern and high-quality equipment and accessories and also equipment used by the specialized units of the police force of the ČR with a practical example. This is offered in the form of a draft requirement for a transport means - a multifunctional special vehicle, intended specifically to intervene in situations against demonstrators, extremists, and football hooligans. At the same time, this paper briefly describes the system of collecting information regarding other modern means used by other security forces and also those which are available on the market, which are then (if suitable and also upon experience from abroad) proposed for development and use under the conditions of the Czech Police practices.
\end{abstract}

Keywords: police force, protection of soft targets, police development, usability of special vehicles, multifunction vehicle

\section{Introduction}

In 2016, the Public Order Police Headquarters, Czech Police Presidium (“ŘSPP”), submitted a proposal to the establishment of working teams of police officers from regional police directorates, who are under the coordination of the highest methodical body of the Public Order Police “ŘSPP.” Following this proposal, the Police President Order No. 286/2016 was created. This act established a working team called Blesk (Lightning) [1], intended for assessment of the current security situation and to evaluate the current needs regarding service tactics for use by the Police of the Czech Republic (hereinafter referred to as the "Police CR") during actions taken against dangerous crime offenders and to be included in procedures used by intervention units of regional directorates of the Police CR and also the special unit guarding nuclear power plants in the Czech Republic, Temelín and Dukovany. The next Police President Order No. 38/2017 has the same purpose, it was established by the Evoluce (Evolution) [2] working team and as with the previous order focuses on material security of police officers, but in the case of riot police officers (which means special riot units of police regional directorates (4) and riot units of regional police directorates (12)), taking into account the tendencies of the security situation. Police President's orders allow the coordinator and the team to invite experts from other workplaces of the Police ČR, but also consultants from companies and suppliers to meet and investigate the latest trends in this field of the market. Team workers have the opportunity to be sent to exhibitions and seminars where a particular technology is presented and where they can find out foreign products and compare them with the means which are currently available to 
the police. No such conceptually formed teams had existed until these teams were formed. Policemen' proposals or requirements were not often listened to or they were strongly misrepresented in other resulting documents. One of the successful projects was dependent primarily on the personal erudition of only one policeman from a special department, who created the future final document regarding the requirements of his work - (training polygon in Zbiroh [3]) literally in the garage.

\section{Research on multifunctional special vehicle}

One of the tangible proposals was the future acquisition of a service vehicle primarily intended for use by riot units. According to the Evolution Team's proposal, this vehicle would be used also by other Police CR units and it will be possible to be deployed for use as an Integrated Rescue System as well. The vehicles concept draft, as presented by $\check{R} S P P$, is the result of the team's work over several years. During this preparation, the requirements of the leaders and commanders of riot units were addressed, and the possibility of vehicle production in domestic and foreign companies was discussed, including visits to riot units abroad. Upon these findings, modification possibilities of already functioning vehicles were evaluated. However, no vehicle, which would at least meet the majority of workgroup requirements, was found within this phase. Then a professional discussion with several representatives of domestic companies took place, wherein the technical possibilities of the vehicle in terms of construction were addressed. During these, professional discussion possibilities of desired vehicle construction and concerning its future activities were agreed. Several companies within the European Union would be technologically capable of developing and subsequently producing the desired vehicle. From the team's point of view, the best possible way would be through the development and production of a prototype with participation of the work team and then to the subsequent performance testing in operation service. Only then the production of other vehicles would be ordered.

\subsection{Usability of new special vehicles}

The Police CR have been using a type of special vehicle with water cannon for a long time. This vehicle type had been widely used before 1989 when they served as coercive means to forcibly end demonstrations. After this year, the water cannon vehicle remained in use by the riot police, but with a strong reduction in their numbers. A lack of these vehicles was later manifested in mass demonstrations on the occasion of the meeting of the Monetary Fund and the World Bank in Prague in 2000 when other vehicles of the Czech Army and Fire Brigade had to be called. The vehicles have now been upgraded, but their numbers and technical condition are currently very low and several vehicles are immobile. Public Order Police Headquarters exploits available possibilities to communicate with other EU countries, where they also deal with legal issues of using a water cannon type vehicle as a coercive means. All neighboring states have included these vehicles in their equipment itinerary, but their use varies according to the legal framework. In this respect, the possibility of using a vehicle as a coercion mean under the Police ČR Act is at the same and often a higher level than abroad. On the other hand, we must state that massive demonstrations are taking place in all neighboring countries with significant disturbances to public order, while in our country, eventual demonstrations are less numerous and calmer. However, it is not possible to predict future developments in the Czech Republic based on this situation, especially concerning the immigration crisis and open borders within the Schengen area. It is, therefore, necessary to have such a coercion means available to protect the life and 
health of intervening police officers, while at the same time allowing termination or at least disrupting such unlawful conduct. Water cannon type vehicles included in the riot police service are a single-purpose vehicle, which its construction is based on the basic fire brigade special vehicle and their parameters and characteristics have not complied with the requirements of the Czech Police for several years. Their deployment is also problematic with regards to their size, maneuverability, and possible documentation of unlawful conduct. As a result of the combination of these elements and characteristics, the vehicles are mainly used for demonstrations and exercises but remain largely unused during safety or security measures. The usability of future vehicles was a key prerequisite in the development of the multifunction vehicle concept. The ǨSPP are fully aware of the duties of proper management and that is why it proposes to change the systemization of these service vehicles when these special vehicles of water cannon type will be replaced by a special multifunction vehicles with a water cannon fitted. The aforementioned amendment shall not affect the wording and interpretation of Act No. 273/2008 Coll., within the Police of the Czech Republic, $\ 52$ let. k) a water cannon, as this is an extension of the name of the official operation transport means. The new concept drafted vehicle envisages that the scope of this act will extend the possibilities of use also for coercive means mentioned under b) tear-forming, electric or other temporarily disabling means, letter $\mathrm{f}$ ) stopping belt, blocking the road forcibly, stopping the vehicle or preventing the vehicle from escaping and avoiding capture and letter g) forcing out using a vehicle.

In addition to the repressive characteristics of the vehicle, it is also necessary to emphasize its tactical capabilities. The technology that the ŘSPP plans to apply will allow on-line transmission of video (or sound) to the headquarters of a particular situation, documentation of unlawful conduct, making calls or communicating information, and a two-way communication with the headquarters of the situation which is being met or with the control center and intervention units. In addition to this, the vehicle will be able to transmit images from areas affected by a natural disaster, industrial accident, a polluted or otherwise contaminated area or from areas otherwise inaccessible. The ŘSPP dealt with the question of usability concerning the individual units of the Police ČR. Upon the analysis of typical and extraordinary activities performed by the Police $\check{C} \mathrm{R}$, the vehicle is required to have defined characteristics and its technical equipment was then designed. Considering that technological and technical developments are moving forward very quickly, there is a possibility for further expansion within the requirements of the live deployment of the vehicle.

The following table compares existing water cannons and planned multifunction vehicles regarding their deployment possibilities for various activities and usage (Table 1).

From the table above, it is clear that the vehicle could be used for numerous operational activities. The reason why the work team and the ŘSPP prefer a multifunction vehicle is based on two factors. The possibility of universal and frequent deployment and saving money, compared to the purchase of more single-purpose vehicles. The actual deployment (in the case of a security measure) is another decisive element that would require at least three separate vehicles with their crew, which then deprive the maneuvering space of intervention units and three crews are therefore necessary, who could have been deployed elsewhere and otherwise. It should be noted that the idea of a universal vehicle, which has been developed by the ǨSPP since 2015, instigated by discussions held by a team of professionals, is going in the right direction. Today we can already see one fire-fighting special vehicle produced by Hlučín Fire Brigade; however, it lacks the basic and essential characteristics of this police multifunction vehicle.

Technical specification (serving just as a base for proposal and numerous negotiations of the team). 


\begin{tabular}{|c|c|c|c|}
\hline Activity typ & & Water cannon & Multifunction vehicle \\
\hline \multirow{2}{*}{$\begin{array}{l}\text { Safety } \\
\text { measures }\end{array}$} & City & Yes, on main roads & Yes, even in restricted areas \\
\hline & Terrain & With limitations & Yes, almost without limits \\
\hline \multirow[t]{4}{*}{ Emergency } & $\begin{array}{l}\text { Industrial } \\
\text { accident }\end{array}$ & $\begin{array}{l}\text { As with fire } \\
\text { brigade support } \\
\text { only }\end{array}$ & $\begin{array}{l}\text { Action headquarters support, fire brigade } \\
\text { support, possible evacuation }\end{array}$ \\
\hline & Floods & No & $\begin{array}{l}\text { Wading up to } 120 \mathrm{~cm} \text {, action headquarters } \\
\text { support, fire brigade support, possible } \\
\text { evacuation }\end{array}$ \\
\hline & Large fire & $\begin{array}{l}\text { As with fire } \\
\text { brigade support } \\
\text { only }\end{array}$ & $\begin{array}{l}\text { Protection from radiant heat and flames, } \\
\text { all-terrain performance capability, action } \\
\text { headquarters support, fire brigade support, } \\
\text { possible evacuation }\end{array}$ \\
\hline & Mass disaster & $\begin{array}{l}\text { As with fire } \\
\text { brigade support } \\
\text { only }\end{array}$ & $\begin{array}{l}\text { All-terrain performance capability, action } \\
\text { headquarters support, fire brigade support, } \\
\text { possible evacuation }\end{array}$ \\
\hline \multirow{5}{*}{$\begin{array}{l}\text { Coercive } \\
\text { means }\end{array}$} & Water cannon & Yes & Yes \\
\hline & Tear agent & No & Yes \\
\hline & $\begin{array}{l}\text { Acoustic or } \\
\text { luminous } \\
\text { temporarily } \\
\text { disabling mean }\end{array}$ & No & Yes \\
\hline & $\begin{array}{l}\text { Blocking the road } \\
\text { using the vehicle }\end{array}$ & Yes & Yes \\
\hline & $\begin{array}{l}\text { Forcing out using } \\
\text { the vehicle }\end{array}$ & $\begin{array}{l}\text { Yes, with } \\
\text { limitations }\end{array}$ & Yes \\
\hline \multirow[t]{5}{*}{$\begin{array}{l}\text { Other } \\
\text { activities }\end{array}$} & $\begin{array}{l}\text { Green border } \\
\text { surveillance }\end{array}$ & No & $\begin{array}{l}\text { Yes, thermovision, night vision, image } \\
\text { transmission }\end{array}$ \\
\hline & Soft targets & Partially & $\begin{array}{l}\text { Thermovision, night vision, camera } \\
\text { recording, calls, mobile roadblock, image } \\
\text { transmission to headquarters }\end{array}$ \\
\hline & $\begin{array}{l}\text { Large sport or } \\
\text { other events }\end{array}$ & $\begin{array}{l}\text { No, only for road } \\
\text { spraying at hot } \\
\text { days }\end{array}$ & $\begin{array}{l}\text { Action headquarters support, image record } \\
\text { and transmission, calls, drinking water in } \\
\text { hot days, road spraying in hot days }\end{array}$ \\
\hline & AMOK & No & $\begin{array}{l}\text { Partially, image and sound transmission to } \\
\text { headquarters, calls, logistics background for } \\
\text { action squads }\end{array}$ \\
\hline & Search actions & No & $\begin{array}{l}\text { Logistics background for units, drinking } \\
\text { water, lighting, electric circuits, camera } \\
\text { surveillance or thermovision }\end{array}$ \\
\hline
\end{tabular}

Table 1.

Table of possibilities and a quick comparison of water cannon and multifunction vehicles.

\subsection{Vehicle basic characteristics and equipment}

\section{(1) Dimensions}

a. Max. height $3.000 \mathrm{~mm}$

- Maximum transport height (without displaced accessories) is set for underpasses and overhead lines in cities, passages to prisons and other enclosed spaces 
b. Max. width $2.550 \mathrm{~mm}$

- Maximum width is set for passage through streets and to meet road traffic rules, when vehicles with a wider width are considered as exceptional and their operation requires special regime and permission.

c. Length - maximum length is not defined

- The length shall coincide with vehicle chassis; however, the vehicles maneuverability being dependant also on the vehicles length will also be a determining factor. Therefore, the shorter the better.

\section{(2) Driveability}

a. Turning diameter - near to $14 \mathrm{~m}$ and less

- This is a key factor because the vehicle must be able to pass to the same locations as the VW Crafter (turning diameter $13.6 \mathrm{~m}$ ) - riot squad vehicles.

b. Terrain passage - the vehicle must be able to pass through heavy terrain including water obstacles and vertical steps

- Driving on roads and paved roads in normal traffic

- Driving on field and forest roads in any weather

- Driving on unpaved terrain on all types of surface

- Wading ability up to $1,200 \mathrm{~mm}$ without preparation

- Ability to overcome vertical steps up to $500 \mathrm{~mm}$

- Ability to overcome trenches up to $500 \mathrm{~mm}$ wide

c. Engine power $-\min .18 \mathrm{~kW} / \mathrm{t}$

- Engine cannot be specified by type, but power values must be set depending on the total weight (maximum instantaneous vehicle weight)

d. Tyres $-14,00$ R20 or 16,00 R20

- "Run Flat" construction rough-terrain tires

- Pressure change possible from the driver's cabin

- Automatic inflation system in case of a small puncture

- Particular type will depend on the chassis used

e. Chassis and drive $-4 \times 4$, both axles steerable

- This special requirement is based on the comparison with other available similar vehicles with this type of chassis and is then a key requirement

f. Other characteristics

- The possibility to change smoothly the height clearance from the driver's cab

- The range without refueling (road, at constant speed $90 \mathrm{~km} / \mathrm{h}$ ) to be at least $500 \mathrm{~km}$

- Max. speed $115 \mathrm{~km} / \mathrm{h}$ (speed limiter) 
- ABS

- Differential lock (axle and inter-axle)

- Automatic transmission allowing speed of $5 \mathrm{~km} / \mathrm{h}$ or less

- There will be a reinforced displacement frame allowing road blockage in front of the driver's cabin, for pushing off an immobile vehicle, clearing the path from fallen trees...

\section{(3) Crew cabin}

a. Extended, two rows of seats with technical space

- The basic crew will consist of a driver, an operator of the water cannon or the functional mast, and a vehicle commander (who has the possibility of taking over an operator's activities)

- One full-value observer seat (commander of the action, units...)

- One emergency seat in case of evacuation

- The seats will be equipped with four-point self-winding belts, with headrests and increased lateral guidance (the emergency seat may be folding and fitted with a basic lumbar belt)

- The seats must provide comfortable seating for several hours (without the possibility to leave the vehicle)

b. Resistant construction with treatment against thrown objects, stones, etc.

- The cab design shall meet the requirements for protection against thrown objects, it shall not restrict the view of the crew, and it shall be easy to maintain and repair

- The possibility of integrating basic ballistic protection, especially against splinters

- An emergency exit for the crew shall be located in the roof

c. Cabin technical equipment

- Air conditioning and independent heating

- Filtered ventilation

- Control of all vehicle technologies

- Camera display units

- Driver's camera display units

- 2 pcs RDST

- A computer with a connection to MBP and tactical software

- A computer with a connection to helicopter image and operating center information

- Data storage for camera recordings with a capacity to store data for a min. $24 \mathrm{~h}$

- Video and audio on-line transmission technology 
- A powerful LED reflector will be placed on the upper exterior of the cab to create a light curtain, to be used as a coercive means through glare and for space lighting

\section{(4) Technical superstructure}

a. Structurally, it must be smoothly connected to crew cabin, and there shall not be any clearance between the cab and the technical superstructure into which fallen or thrown objects might enter

b. The surface must withstand thrown objects, and easy and cheap repair is essential

c. Location of all technology and equipment must be easily accessible but must also be secured against misuse or theft

d. Water tank with min. capacity $4000 \mathrm{~L}$, the material and construction used must allow easy cleaning, and transport of drinking water protected from any contamination

e. The rear part of the superstructure will accommodate technologies allowing the connection of a drinking water hose

f. Hose inputs/outputs will be located in rear part (tank filling - flow line with hose)

g. Power generator distribution panel $(3 \times 230 \mathrm{~V} \mathrm{10A,} 2 \times 230 \mathrm{~V} 16 \mathrm{~A})$ will be placed at the lateral part

h. A power generator with connection to the vehicle tank - remote-controlled from the cab, with automatic operation, controlled from the distribution panel

i. A tear gas tank

j. A coloring agent tank

k. Telescopic and retractable fence closures of $0-150 \mathrm{~cm}$ width on each side at vehicles front part

1. In the upper part of the front, there will be placed a monitor mount (channel line) - at its resting position, it will be inserted into the superstructure of the roof, and in its use, it will be extended and will cover the space of $\min .270^{\circ}$ around vehicles front-to-back axle

$\mathrm{m}$. In the vehicles upper front part, there will be a telescopic mast equipped with a rotator carrying a UHD camera with night-time (low-lux) capability (IR illumination), thermal imaging camera, and an LRAD-type device (min. level 450LX)

n. A telescopic mast will be placed in the upper rear part to enable illumination of the circular space within a radius of $50 \mathrm{~m}$

\section{(5) Other technical elements}

a. On the top of the vehicle, there will be strobe lights (blue/red) covering the $360^{\circ}$ space around the vehicle 
b. Entire vehicle will be covered by a fire protection system

c. The vehicle will have increased protection against radiant heat and flames

d. There will be high-pressure nozzles above the windscreen for washing of adhering substances on the windscreen

e. The vehicle will be fitted with visual cameras that will allow driving without the driver's window view (including the camera on the roof of the body to check the clearance and displaced accessories) (Figure 1)

\subsection{Comments to vehicle equipment}

The team has designed the vehicle so that the crew can perform the tasks asked of the headquarters while responding with security measures and mainly to support the intervening units. Its construction is designed to be robust because heavy equipment is currently missing within the equipment of the Czech Police and it is necessary to cooperate with Fire Brigade units, which is not always convenient or possible taking into account time requirements. The possibility of using LRAD devices as a safety measure should be highlighted. This equipment is already in use by the police and its deployment greatly facilitates and at the same time improves the performance regarding challenges and the transmission of information. It should also be mentioned that the device can be used as a coercive means with a temporary disabling effect. A camera system allowing documentation of unlawful conduct, which allows the transmission of up-to-date information of the staff during these measures direct from the place of the intervention and thus providing surveillance of the situation to commanders of the intervening units is another element. The vehicle itself can safely move directly on the site of the intervention without any risk of its significant damage (unlike current camera cars). At the same time, the commander shall be a part of the vehicle, who may analyze onthe-spot the evolution of measures concerning unlawful conduct and provide the headquarters or the intervening units with this information. Lastly, but not least,

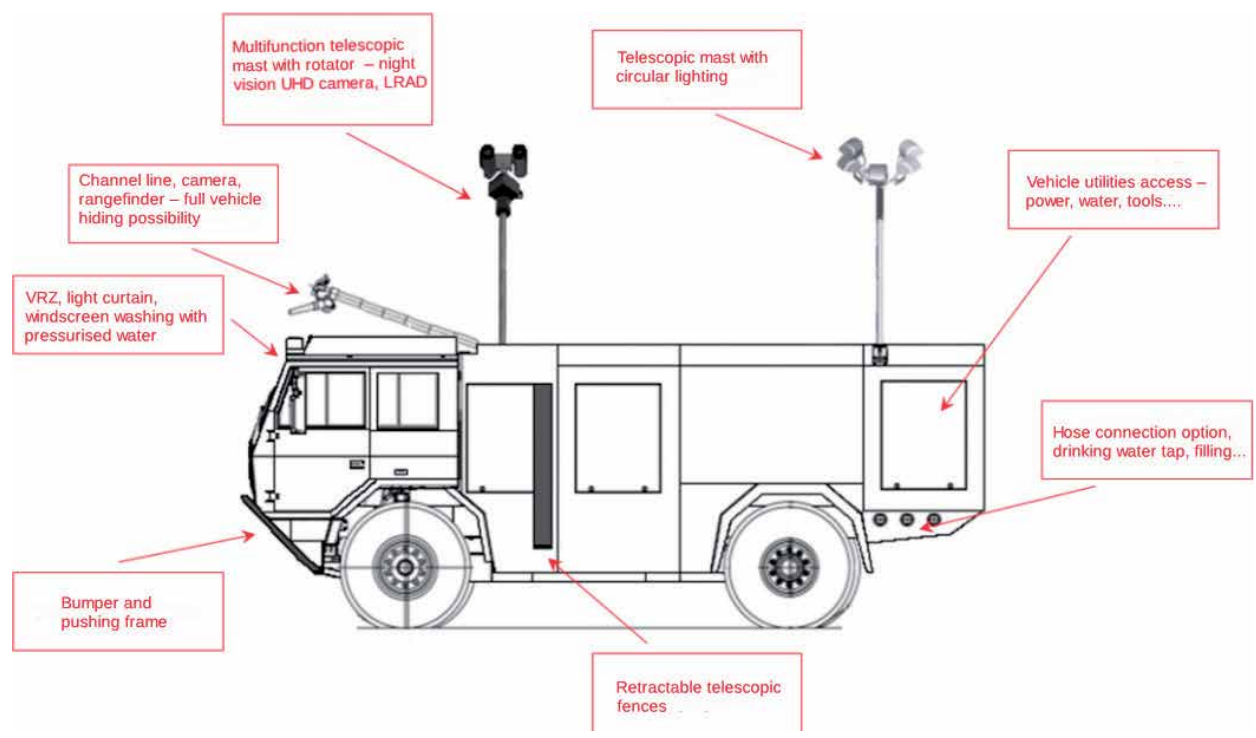

Figure 1.

Layout of proposed technical elements. 
is the use of a water cannon (monitor) with continuously variable pressure and shape of the water jet. The monitor itself will be equipped with a rangefinder and camera, so the operator will be able to control the monitor using controls from the cab, but at the same time, he will precisely see where the water stream exactly hits. Another advantage is that the use of the water jet against a specific perpetrator can be automatically documented. The whole device will allow the tear-forming agent to be mixed into the water stream and sprayed over a large area within a second or a short impulse to cover a small space. Marker paint admixture is less aggressive, it serves as a clear identifier for intervening police officers that an individual is likely to have committed an offence and can be apprehended to explain themselves after the cessation of such a measure and compare camera images within a particular proceeding. Especially in conditions of reduced visibility, a so-called light curtain can be used, which may serve as a coercive means (painful stimulus when looking into the light), but at the same time allows for good illumination of the targeted site and its main purpose is to hide the activities of units behind the vehicle.

The general advantage of this vehicle is that it is not necessary to have the monitor in a standby position during normal measures, but that the vehicle acts only as a camera car. If the vehicle is used outside this measure, it will allow the units to create a background with utilities (light, electricity, water, transport of other materials, transport, and a heavy trailer) even to places where other police vehicles can get into problems or not be able to reach at all. The possibility to remove obstacles from the road by either pushing or by use a winch is another important feature. If necessary, the vehicle can travel through water with a depth of approx. $120 \mathrm{~cm}$, even with an unpaved watercourse bottom.

Enumerating all deployment possibilities is very difficult because it will depend on the ability of commanders to utilize the maximum potential of this vehicle. It is clear that this vehicle meets the requirements of modern trends and concepts of security forces within the EU and the world.

\section{Conclusion}

This paper presents the function and development of requirements for modern and high-quality equipment and for equipment of special units of Police ČR with a practical example, which comes in the form of a draft requirement for a means of transport - a multifunctional special vehicle, intended to intervene against demonstrators, extremists, and football hooligans. No such vehicle exists now in the Czech Republic, of which its development and proposal for future possibilities of its use which has been created by a team of police officers who perform daily service in the streets within security measures, so it would be quite unique in its purchase and production, but the authors do not have the ambition to describe in this paper the details of the future steps of the vehicles development or its purchase. The authors describe the means and idea of creating working teams, consisting of ordinary police officers, who thanks to the work of such a team, can from their own experience suggest its optimal means, which, in their opinion, is missing in practice and would be useful. At the same time, this paper briefly describes the system of collecting information on modern means used by other security forces and on the market, which is then (if suitable and also upon experience from abroad) can be proposed for development and use under the conditions of the Czech Police practice. 


\section{Author details}

Martin Hrinko ${ }^{1}$, David Palička ${ }^{2 *}$, Leoš Hájek ${ }^{3}$ and Petr Kubický ${ }^{2}$

1 VSCI Praha, Czech Republic

2 VŠB-TU FBI Ostrava, Czech Republic

3 Public Order Police Headquarters, Czech Police Presidium, Czech Republic

*Address all correspondence to: palickadavid@seznam.cz

\section{IntechOpen}

(C) 2020 The Author(s). Licensee IntechOpen. This chapter is distributed under the terms of the Creative Commons Attribution License (http://creativecommons.org/licenses/ by/3.0), which permits unrestricted use, distribution, and reproduction in any medium, provided the original work is properly cited. (cc) BY 
The Police Development and Protection of Soft Targets

DOI: http://dx.doi.org/10.5772/intechopen.92072

\section{References}

[1] Police President Order No. 286/2016 by which Blesk (Lighting) working team is established

[2] Police President Order No. 38/2017 by which Evoluce (Evolution) working team is established

[3] HRINKO M. Unique Police Training Polygon in Terms of Activity and Training Improvement of the Intervention Units of the Police of the Czech Republic. Zilina: Communications - Scientific Letters of the University of Zilina, Slovak Republic; 2017, 4/2017, pp. 111-116. EV 3672/09. ISSN: 1335-4205 
